\title{
Znaczenie i skutki budowy wybranych elementów infrastruktury nowoczesnego transportu kolejowego
}

pod redakcja

Remigiusza Kozłowskiego

ŁÓDZKIEGO 
Remigiusz Kozłowski - Katedra Logistyki, Wydział Zarządzania Uniwersytet Łódzki, 90-237 Łódź, ul. Matejki 22/26

remigiusz@uni.lodz.pl

\author{
RECENZENT \\ Michał Marczak \\ REDAKTOR WYDAWNICTWA UŁ \\ Katarzyna Gorzkowska \\ SKŁAD I ŁAMANIE \\ AGENT PR \\ OKŁADKĘ PROJEKTOWAŁA \\ Barbara Grzejszczak
}

Na okładce wykorzystano ilustrację ze strony www.microsoft.com

(C) Copyright by Uniwersytet Łódzki, 2012

Wydane przez Wydawnictwo Uniwersytetu Łódzkiego

Wydanie I. W.06095.13.0.K

ISBN 978-83-7525-631-4

Wydawnictwo Uniwersytetu Łódzkiego

90-131 Łódź, ul. Lindleya 8

www.wydawnictwo.uni.lodz.pl

e-mail: ksiegarnia@uni.lodz.pl

tel. (42) 66558 63, faks (42) 6655862

Druk i oprawa: Quick Druk 


\section{Spis treści}

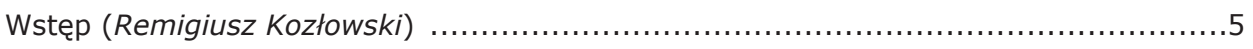

1. Transport kolejowy w Unii Europejskiej i w Polsce

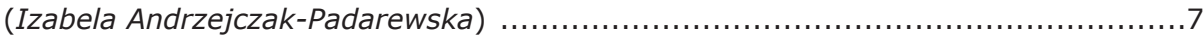

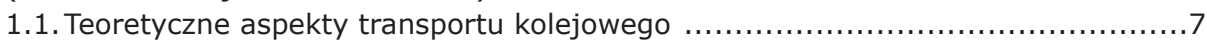

1.2. Znaczenie transportu kolejowego dla Unii Europejskiej .......................... 14

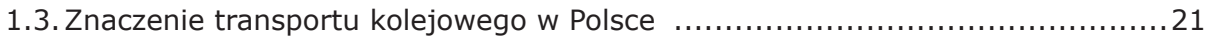

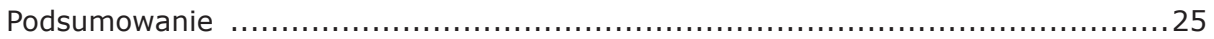

2. Koleje dużych prędkości (Izabela Andrzejczak-Padarewska) . .......................27

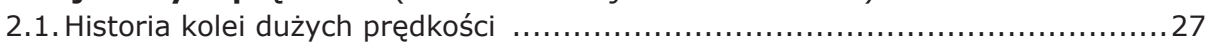

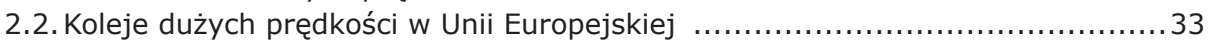

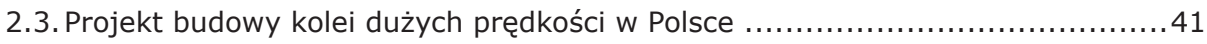

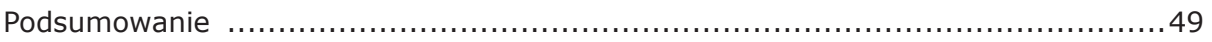

3. Tunel średnicowy w Łodzi ważnym elementem projektu kolei dużych

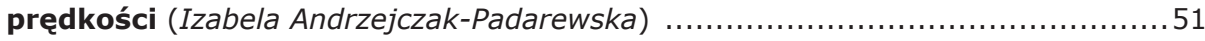

3.1. Historia łódzkiego węzła kolejowego oraz jego znaczenie na mapie

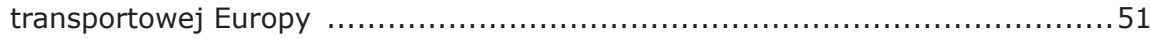

3.2. Techniczne aspekty budowy tunelu średnicowego i dworca Łódź Fabryczna ......59

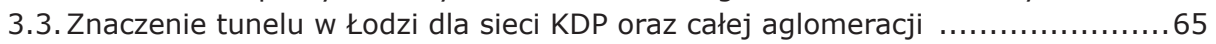

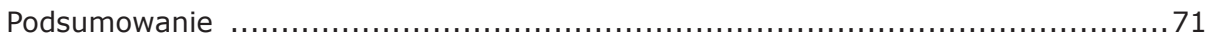

4. Tunel średnicowy w Lipsku i Łodzi (Marek Przybylak) .........................73

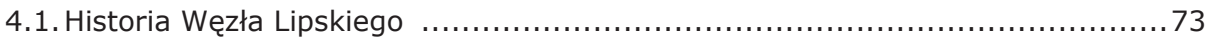

4.2. City Tunnel Leipzig, czyli projekt związany z budową tunelu średnicowego

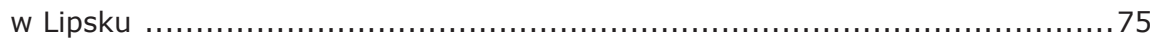

4.3. Projekt budowy tunelu średnicowego pod ulicami Łodzi $\ldots \ldots \ldots \ldots \ldots \ldots \ldots \ldots \ldots \ldots . \ldots$

4.4. Metoda wykonania tunelu, jego parametry, warianty budowy i kwestia

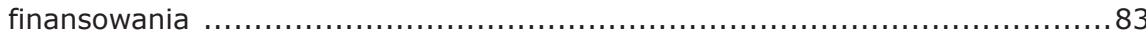

4.5. Znaczenie łódzkiego tunelu średnicowego dla rozwoju transportu

kolejowego w Polsce - budowa kolei dużych prędkości ........................... 89

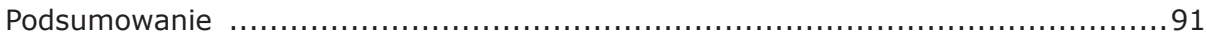

5. Rozwój multimodalnego węzła Łódź Olechów (Katarzyna Raj) ...................95

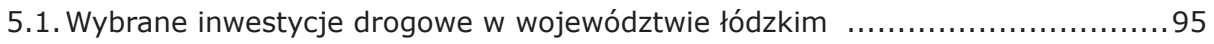

5.2. Infrastruktura kolejowa i jej przyszłość w regionie łódzkim .......................99

5.3. Plany budowy węzła drogowo-kolejowego Łódź Olechów i jego efekty ........... 105

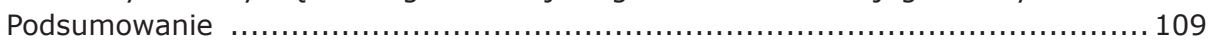

6. Węzeł kolejowy w Karsznicach (Anita Kącka) ................................... 111

6.1. Geneza powstania i historia rozwoju węzła kolejowego w Karsznicach ...........111

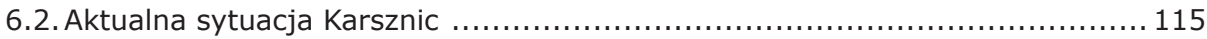

6.3. Uwarunkowania rozwoju węzła kolejowego w Karsznicach ....................... 121

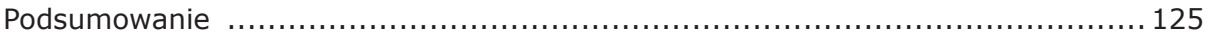


7. Wpływ Karsznic na rozwój regionu (Anita Kącka)

7.1. Rozwój regionu w oparciu o plany Biura Planowania Przestrzennego

Województwa Łódzkiego i samorządów lokalnych

7.2. Napotykane problemy podczas realizacji programu rozwoju

Podsumowanie

8. Wpływ infrastruktury transportowej na Kutno i jego okolice

(Katarzyna Dąbek)

8.1. Oddziaływanie infrastruktury transportowej na rozwój Łódzkiej Specjalnej Strefy Ekonomicznej Podstrefy Kutno

8.2. Oddziaływanie dróg kołowych i szynowych na rozwój miasta i powiatu kutnowskiego 141

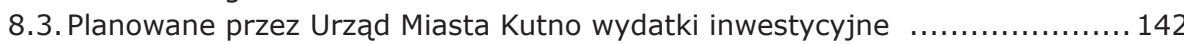

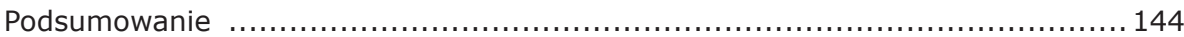

9. Metro w Londynie jako modelowy przykład rozwiązania transportu

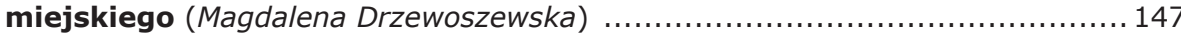

9.1. Historia powstania i rozwoju systemu kolei podziemnych w Londynie ......... 147

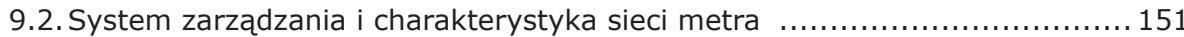

9.3. Plany rozwoju i modernizacji miejskiej kolei podziemnej ........................ 159

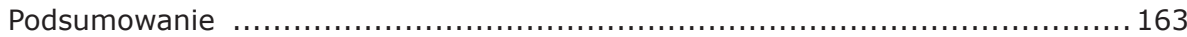

10. Rodzaje miejskiego transportu szynowego w Londynie

(Magdalena Drzewoszewska) .................................................... 165

10.1. Charakterystyka lekkiej kolei nadziemnej ................................... 165

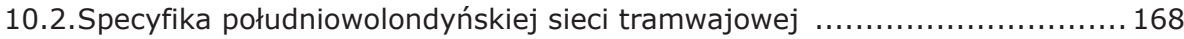

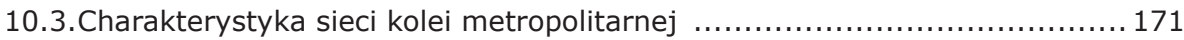

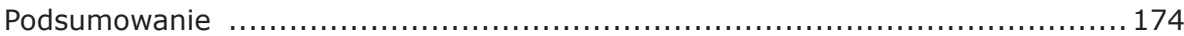

11. Plany budowy Łódzkiej Kolei Aglomeracyjnej (Łukasz Trzeszczak) ...........177

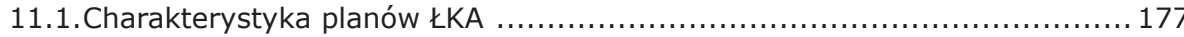

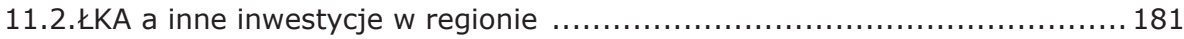

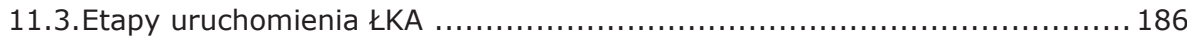

11.4.Identyfikacja czynników zagrażajacych budowie ŁKA ........................ 189

11.5. Propozycje zniwelowania zagrożeń .......................................... 192

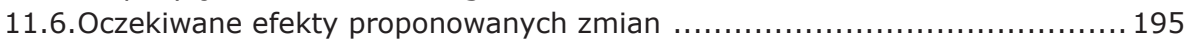

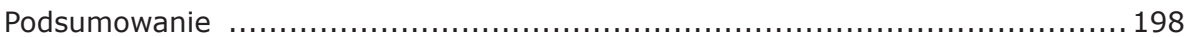

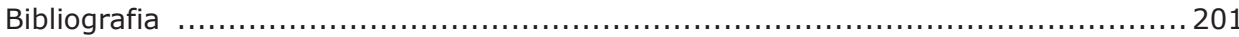

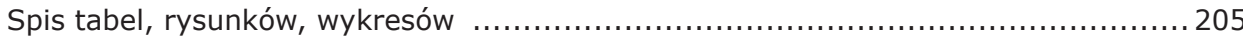




\section{Wstęp}

Transport kolejowy w wielu krajach, w tym także w Polsce, był zaniedbany przez kilka dziesięcioleci, a obecnie przeżywa renesans. Unia Europejska stawia na rozwój tej gałęzi transportu i planuje przeznaczyć ze swych środków budżetowych znaczące kwoty na inwestycje w rozwój kolejnictwa.

Technologie wykorzystywane $\mathrm{w}$ transporcie kolejowym były jednak rozwijane głównie w Japonii i Francji. W obszarze transportu pasażerskiego koleje dużych prędkości są w stanie konkurować zarówno $z$ transportem drogowym (przejazdami autostradami lub drogami ekspresowymi), jak i transportem lotniczym. Polska zamierza także zbudować taką sieć na swoim terenie.

Dla kolei bardzo ważne jest, aby jej dworce były ulokowane tam, gdzie łatwo jest dostać się pasażerom. W aglomeracjach miejskich w celu spełnienia tego warunku należy budować podziemne tunele. Przykładem bardzo dobrego rozwiązania jest tunel w Lipsku (w Niemczech) oddany do użytku w 2011 r. Natomiast w Polsce dwa tunele podziemne przeznaczone dla kolei powstaną w Łodzi - jeden dla kolei konwencjonalnej, a drugi dla kolei dużych prędkości.

Kolej w celu spełniania swoich zadań w obszarze transportu towarów musi budować węzły przeładunkowe. W regionie łódzkim jest kilka dogodnych lokalizacji dla takich obiektów. W niniejszym opracowaniu zostana scharakteryzowane najważniejsze z nich.

Nowoczesny transport to także metro. Do najbardziej rozbudowanych i zaawansowanych technologicznie na świecie należy system metra londyńskiego. Spełnia on bardzo ważne zadania dla prawidłowego funkcjonowania miasta i jest intensywnie zintegrowany z koleja nadziemna oraz systemem sieci tramwajowej.

Odrębny sektor kolejnictwa stanowi kolej aglomeracyjna. W opracowaniu dokonano charakterystyki aktualnie budowanej Łódzkiej Kolei Aglomeracyjnej. Skupiono się na identyfikacji problemów z jej powstawaniem oraz opracowano propozycje ich zniwelowania.

W dalszych częściach niniejszej publikacji zostaną zaprezentowane wspomniane wyżej zagadnienia. Autorzy dołożyli wszelkich starań, by kompleksowo przedstawić jak najbardziej aktualny materiał - stan zaawansowania planowania i budowy infrastruktury kolejowej na październik 2012 r. 



\title{
1. Transport kolejowy w Unii Europejskiej i w Polsce
}

\author{
Izabela Andrzejczak-Padarewska*
}

\subsection{Teoretyczne aspekty transportu kolejowego}

Transport kolejowy, podobnie jak samochodowy, to gałaź transportu kołowego. Według innych podziałów oba wyżej wymienione można uznać również za gałęzie transportu lądowego lub - jeszcze szerzej - powierzchniowego.

Choć kolej zajmuje drugie miejsce, po samochodach, wśród najpopularniejszych środków transportu w gospodarce rynkowej ${ }^{1}$, to lata swej świetności m a już za sobą. Największy rozkwit tej gałęzi przypada na druga połowę XIX i pierwszą połowę XX wieku. Przyczyniła się ona na przestrzeni tych lat do rozwoju przemysłu, handlu, formowania się obecnych gospodarek, a także wzrostu mobilności ludności. W dzisiejszych czasach wykorzystanie maszyny parowej do napędu lokomotywy nazywane jest "II rewolucja w transporcie"2.

Aby mówić o systemie transportowym, należy najpierw wskazać, iż składa się on z:

- środków transportowych oraz

- sieci transportowej, którą dalej można podzielić na elementy punktowe i liniowe.

W przypadku kolei do elementów liniowych zalicza się sieć dróg kolejowych. Do elementów punktowych systemu kolejowego zalicza się obiekty, w których następuje stacjonarna obsługa pasażerów, ładunków i środków transportowych. Sa to m.in.: stacje węzłowe i pośrednie, terminale kontenerowe, stacje rozrządowe czy bocznice kolejowe.

Klasyfikację taboru kolejowego, ze względu na kryterium konstrukcyjne, przedstawiono na rys. 1. Należy wyjaśnić, iż pojazdy trakcyjne to takie wyposażone $\mathrm{w}$ napęd elektryczny lub spalinowy, pełniące

* Mgr Izabela Andrzejczak-Padarewska - Katedra Logistyki, Wydział Zarządzania Uniwersytetu Łódzkiego, ul. Matejki 22/26, 90-237 Łódź.

${ }^{1}$ K. Ficoń, Zarys mikrologistyki, Bel Studio Sp. z o.o., Warszawa-Gdynia 2004, s. 237.

2 J. Neider, Transport międzynarodowy, Polskie Wyd. Ekonomiczne, Warszawa 2008, s. 67. 
funkcję jednostek pociągowych dla formowanych składów osobowych czy towarowych (czyli wagonów bezsilnikowych).

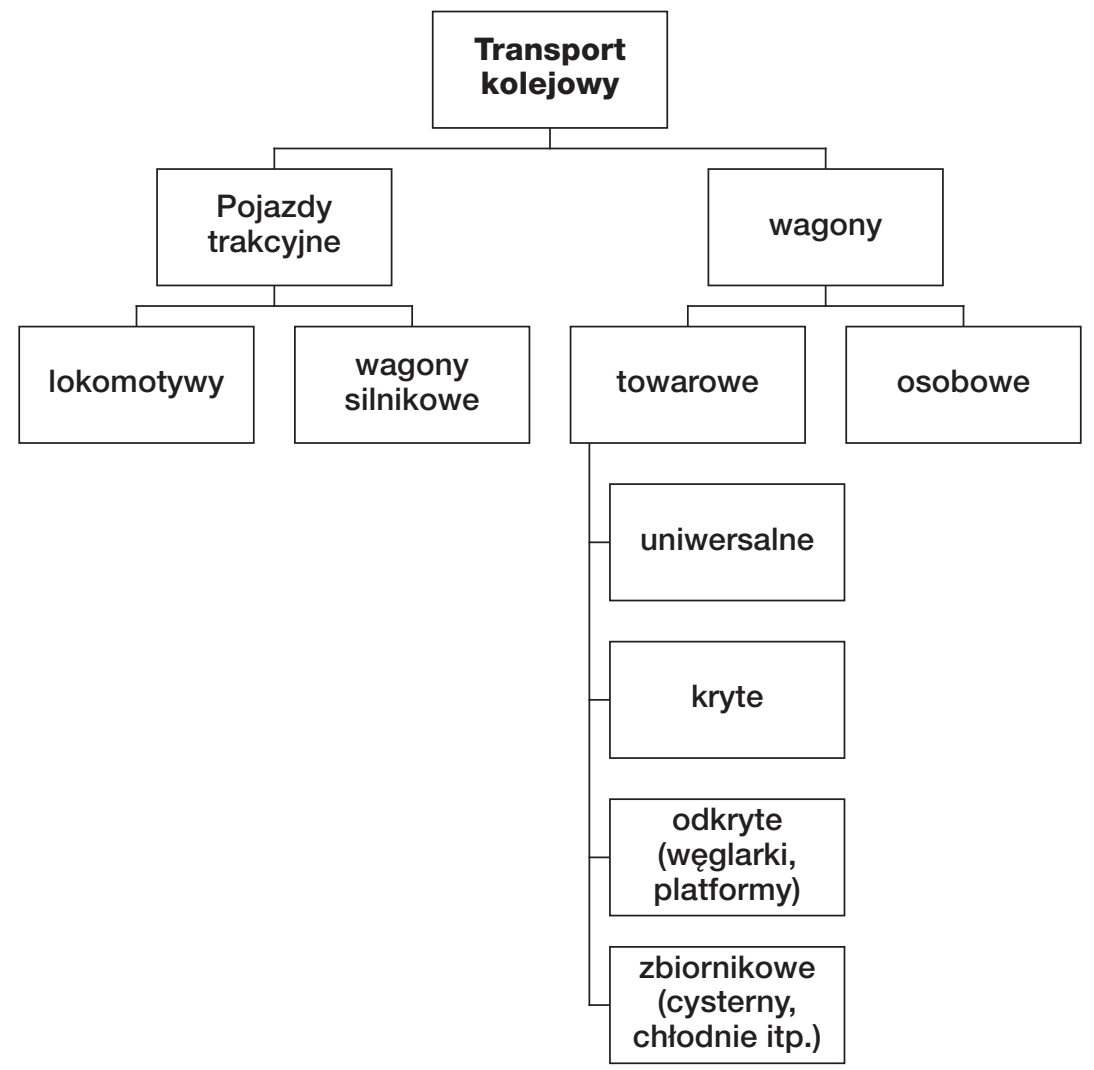

Rysunek 1. Klasyfikacja kolejowych środków transportu

Źródło: K. Ficoń, Zarys mikrologistyki, Bel Studio Sp. z o.o., Warszawa-Gdynia 2004, s. $237^{3}$

Spadek znaczenia kolei $w$ drugiej połowie XX i na poczatku XXI wieku podyktowany jest wieloma słabościami, jakie ta gałą́ ujawnia $w$ porównaniu z pozostałymi (głównie samochodowym). Przede wszystkim przewóz towarów trwa długo i po ściśle wyznaczonych trasach. Długi czas transportu ${ }^{4}$ niesie zagrożenie związane z pogorsze-

${ }^{3}$ J. Neider rozszerza klasyfikację wagonów towarowych, dodając do tej listy platformy (wagony bez burt bocznych i czołowych), służące do przewozu drewna, maszyn, ładunków niewymiarowych oraz wagony specjalizacyjne do przewozu samochodów, platformy kontenerowe, wagony do przewozu cementu, wapnia i zwierząt (Transport..., s. 68).

${ }^{4}$ Wskazuje się tutaj nie tyle na długi czas przewozu, związany z prędkościami rozwijanymi przez kolej, ile na czas, który trzeba doliczyć, związany z: dowozem towaru 
niem się parametrów użytkowych towarów, jak również kradzieżą czy zniszczeniem. W celu ochrony towaru należałoby zatrudnić wspierające służby ochroniarskie, jednak znacznie zwiększyłoby to koszty transportu. Nierównomierne rozmieszczenie linii kolejowych sprawia, iż towary trzeba dostarczać i odbierać ze stacji kolejowych innym środkiem transportu - najczęściej samochodem. Co więcej, kolej nie jest transportem dyspozycyjnym w sensie czasowym, gdyż wymaga całkowitego podporządkowania się ustalonym przez przewoźnika terminom i rozkładom jazdy.

W przewozach międzynarodowych ${ }^{5}$ za największą wadę transportu kolejowego uznaje się brak harmonizacji przepisów i rozwiązań technicznych.

Obecna sytuacja jest wynikowa procesu budowy kolei w Europie. W poszczególnych krajach powstawała ona w oderwaniu od systemów kolejowych innych państw, dopasowana jedynie do lokalnych warunków i możliwości. Późniejsza modernizacja kolei, która postępowała w nierównomiernym tempie, doprowadziła do zwiększenia dysproporcji w standardach i parametrach technicznych. Z tej przyczyny w dzisiejszej Unii Europejskiej (UE) występują: 4 różne szerokości torów, 7 różnych systemów zasilania trakcji elektrycznej, 25 różnych systemów sygnalizacji i zupełnie odmienne narodowe przepisy o prowadzeniu ruchu drogowego ${ }^{6}$. Następstwem takiego stanu rzeczy jest ograniczenie interoperacyjności ${ }^{7}$ kolei, skomplikowanie prowadzenia pociągów i zagrożenie bezpieczeństwa ruchu.

Dochodzi do sytuacji, kiedy na granicy trzeba zmienić lokomotywę (jeśli występuje zmiana zasilania, a lokomotywa jest jednosystemowa), maszynistę (bo nie zna przepisów i sygnalizacji) oraz wagony (ze względu na nieodpowiedni rozstaw kół). Nie dziwi, że zniechęca to do korzystania z transportu kolejowego, jeśli wewnątrz UE, gdzie nie ma odpraw granicznych, czynności te zabierają około 2 godzin ${ }^{8}$.

do najbliższej stacji, przeładunkiem towaru z samochodu na wagon, dostarczeniem wagonu na stację węzłowa, uformowaniem składu pociągu, czy związany z ponownym przeładunkiem towaru $z$ wagonu na samochód i dowiezieniem ładunku tym środkiem transportu do miejsca docelowego.

${ }^{5} \mathrm{~W}$ tym rozdziale zostana przedstawione jedynie aspekty związane z europejską siecią kolejowa, stąd też określenie "przewozy międzynarodowe” należy rozumieć jako przewozy wykonywane tylko w obrębie Starego Kontynentu.

6 J. Neider, Transport..., s. 69-70.

7 Według Dyrektywy 2001/16/WE, interoperacyjność "jest to zdolność transeuropejskiego systemu kolejowego do bezpiecznego i niezakłóconego ruchu pociągów na terenie państw członkowskich Unii Europejskiej, polegająca na spełnieniu podstawowych wymagań".

8 J. Neider, Transport..., s. 70. 
Wśród zalet transportu kolejowego wskazuje się m.in. na dużą dostępność przestrzenną. Objawia się to stosunkowo gęstą siecią linii kolejowych oraz licznymi punktami obsługi stacjonarnej ładunków i pasażerów. Co więcej, sieć ta jest silnie powiązana z dużymi ośrodkami rynkowymi, a połączenia z innymi gałęziami transportu są liczne i dogodne.

Kolejną bardzo istotną zaletą jest duże zróżnicowanie taboru, przystosowanego do przewozu towarów o różnorodnej podatności transportowej: od ładunków masowych po przewozy specjalistyczne (np. paliwa, maszyny, drewno).

Transport kolejowy wyróżnia także niezawodność i regularność powiązań. "Cechuje go ściśle określona częstotliwość i rytmiczność świadczonych usług przewozowych" . Wskazuje się również na opłacalność wykorzystania kolei $w$ długich trasach ze względu na silną degresję kosztów jednostkowych. Oznacza to, że udział kosztów stałych w transporcie kolejowym jest znaczny i przewozy na małych odległościach moga stać się nieopłacalne ze względu na narzut tych kosztów. Gałąź ta staje się najbardziej opłacalna w przewozach na średnie i duże odległości, gdyż koszty stałe "rozkładaja się" na przebyte kilometry.

Cechą odróżniajaca transport kolejowy od samochodowego jest również jego bezpieczeństwo. Wystarczy wspomnieć, że w 2007 r. na drogach Unii Europejskiej w wypadkach zginęło 42448 osób, podczas gdy w wypadkach kolejowych tylko 76 pasażerów (dane te nie uwzględniaja wypadków pracowników kolei oraz osób, które zostały potrącone przez pociąg) ${ }^{10}$.

Jednak najważniejszą z zalet transportu kolejowego, która „popycha" Unię Europejską do działań w celu reformowania, ujednolicania i unowocześniania kolei, jest jej aspekt ekologiczny. W broszurze przygotowanej przez Wspólnotę Kolei Europejskich ${ }^{11}$ we współpracy z Międzynarodowym Związkiem Kolejowym ${ }^{12}$ zawarto informację,

${ }^{9}$ K. Ficoń, Zarys mikrologistyki, s. 238.

${ }^{10}$ Dyrekcja Generalna ds. Energii i Transportu Komisji Europejskiej, EU energy and transport in figures. Statistical Pocketbook 2009, s. 95.

${ }^{11}$ Wspólnota Kolei Europejskich oraz Zarządców Infrastruktury Kolejowej (The Community of European Railway and Infrastructure Companies - CER) to największa europejska organizacja, zrzeszająca 64 firmy związane z koleja, z siedzibą w Brukseli. Polskę reprezentują Polskie Koleje Państwowe S.A. oraz prywatni przewoźnicy: Rail Polska i CTL Logistics.

12 Międzynarodowy Związek Kolejowy (fr. Union Internationale des Chemins de Fer - UIC) jest organizacją o największym znaczeniu i zasięgu światowym, zrzeszającym firmy związane z transportem kolejowym, z siedzibą w Paryżu. Związek powstał w 1922 r., a w roku 2006 obejmował 171 członków z 87 państw (instytuty badawcze, przewoźnicy, operatorzy infrastruktury kolejowej itp.). Polskę reprezentują Polskie Koleje Państwowe S.A. (J. Neider, Transport..., s. 75). 
iż kolej emituje średnio o 3-10\% mniej $\mathrm{CO}_{2}$ niż transport samochodowy czy lotniczy ${ }^{13}$. Wskazuje się również, iż w latach 1990-2005 europejska kolej zmniejszyła emisję dwutlenku węgla o $21 \%$ w wartościach absolutnych (w tym na pasażerokilometrze o $14 \%$, a na tonokilometrze o $28 \%$ ). Dla porównania z innymi gałęziami transportu, w broszurze zamieszczono również zestawienie emisji dwutlenku węgla przy przewozie 100-tonowego ładunku na trasie Basel-Rotterdam, w którym kolej wypada kilkakrotnie lepiej od "swoich konkurentów" (wykres 1).

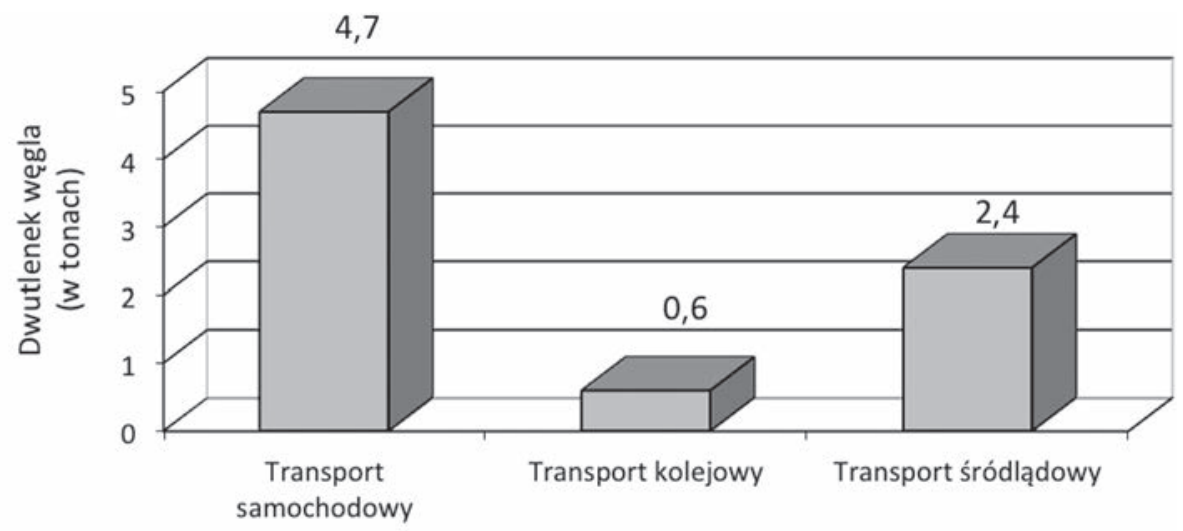

Wykres 1. Emisja dwutlenku węgla związana z przewozem 100-tonowego ładunku na trasie Basel-Rotterdam $(700 \mathrm{~km})$

Źródło: CER, UIC, Rail Transport and Environment. Facts \& Figures, November 2008, s. 7, za: http://www.uic.org/homepage/FactandFig\%2011-08.pdf

[z dn. 15.12.2009]

Przewaga transportu kolejowego jest jeszcze większa w przypadku przewozu osób i przeliczenia emisji $\mathrm{CO}_{2}$ na 1 pasażera. Tym razem badania przeprowadzono na trasie Berlin-Frankfurt, a wyniki przedstawia wykres 2.

W obliczu negocjacji między państwami, dotyczących wprowadzenia limitów emisji dwutlenku węgla ${ }^{14}$, kwestia „czystego" transportu (zwłaszcza, że sektor ten przyczynia się do emisji aż 14\% gazów cieplarnianych, w tym do $20 \%$ dwutlenku węgla ${ }^{15}$ ) staje się priorytetową.

${ }^{13}$ CER, UIC, Rail Transport and Environment. Facts \& Figures, November 2008, s. 3.

${ }^{14}$ Autor ma na myśli m.in. Protokół z Kioto z 1997 r., niedawną Konferencję w Kopenhadze (7-18 grudnia 2009 r.) oraz jednostronne starania Unii Europejskiej o ograniczenie emisji gazów cieplarnianych.

${ }^{15}$ www. klimatdlaziemi.pl/index.php?id=184\&lng $=\mathrm{pl}$ [z dn. 07.12.2011]. 


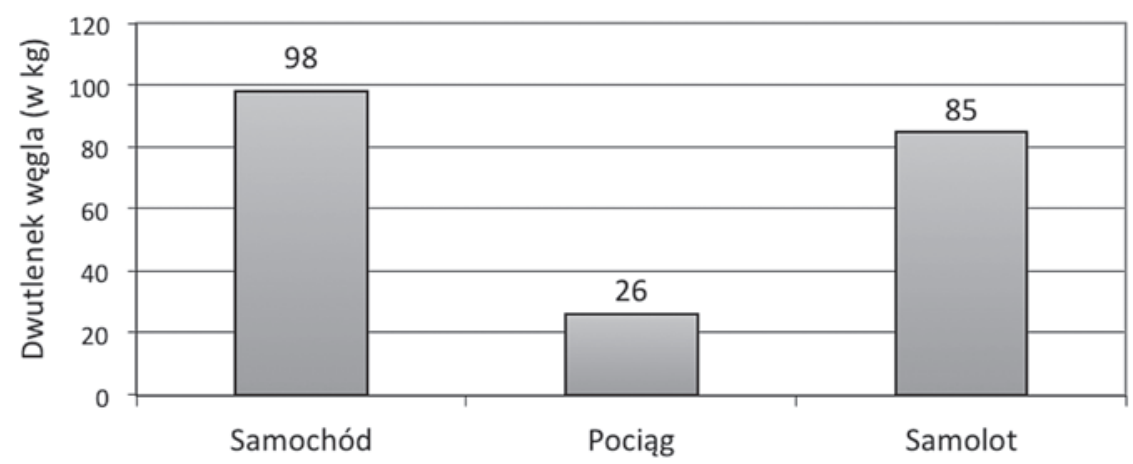

Wykres 2. Emisja dwutlenku węgla związana z przewozem 1 osoby na trasie Berlin-Frankfurt ( $545 \mathrm{~km}$ )

Uwaga: należy zaznaczyć, iż w przypadku transportu lotniczego doliczono emisję $\mathrm{CO}_{2}$ związaną z dowozem osoby na i z lotniska Źródło: jak do wykresu 1

Gwałtowny wzrost przewozów samochodowych w ostatnich latach, nieproporcjonalny do rozwoju infrastruktury drogowej, nasilił zjawisko kongestii. Statystyki podaja, że codziennie 7500 km autostrad Unii Europejskiej jest zablokowanych przez "korki"16. Zatłoczenie dróg powoduje koszty związane ze zwiększonym zużyciem paliwa, utratą czasu, niewywiązywaniem się przez przewoźników z terminów oraz przyczynia się do wzrostu liczby wypadków, natężenia hałasu i zanieczyszczenia powietrza ${ }^{17}$. Rozwiązanie tych problemów stanowi transport kolejowy, który dzięki dobrej przepustowości sieci kolejowej daje szansę dotarcia na miejsce bez "stania w korku". Nieuczciwym jednak byłoby nie wspomnieć, że 20\% europejskiej sieci kolejowej (czyli ok. 16000 km) jest klasyfikowana jako tzw. "wąskie gardło"18, co oznacza, że jeśli nasili się użytkowanie sieci kolejowej w tych miejscach, to w nich również utworzą się "korki".

${ }^{16}$ Dyrekcja Generalna ds. Prasy i Komunikacji Komisji Europejskiej, Europe at a crossroads. The need for sustainable transport, s. 4, za: http://ec.europa.eu/publications/ booklets/move/39/en.pdf [z dn. 11.11.2012].

17 Sir Rod Eddington w swoim raporcie, przygotowanym dla rządu brytyjskiego, wskazuje, że w ruchu miejskim $89 \%$ opóźnień spowodowanych jest kongestią. Całkowite jej wyeliminowanie (choć to niemożliwe) mogłoby przynieść Wielkiej Brytanii oszczędności rzędu 7-8 mld euro rocznie, natomiast pozostawienie tego zjawiska bez kontroli doprowadzi do "zmarnowania" kolejnych 22 mld euro rokrocznie w samej tylko Anglii (na podstawie: R. Eddington, The Eddington Transport Study, za: http://www.dft.gov.uk/ adobepdf/187604/206711/executivesummary.pdf [z dn. 11.10.2012])

${ }^{18}$ Dyrekcja Generalna ds. Prasy i Komunikacji Komisji Europejskiej, Europe at a crossroads..., s. 11. 
Na przyszły wzrost przewozów tą gałęzią transportu może także wpłynąć proces unowocześniania kolei, obejmujący m.in.:

- rozkwit szybkiej kolei (który zostanie dokładniej omówiony w rozdziale 2),

- modernizację taboru, w tym wprowadzenie pociągów wielosystemowych czy wózków o zmiennym rozstawie kół, które poprawią interoperatywność kolei,

- rozwój kolei niekonwencjonalnej, która zamiast na zestawach kołowych będzie poruszać się na poduszkach magnetycznych lub powietrznych, po specjalnie przygotowanych konstrukcjach inżynierskich zastępujących tory ${ }^{19}$,

- zastosowanie kolei w miastach, jako środka komunikacji miejskiej, dzięki możliwości łączenia technologii tramwajowej i kolejowej20.

Nie bez znaczenia dla przyszłości kolei pozostaje również rozwój transportu intermodalnego oraz konteneryzacji. Dzięki zastosowaniu różnych środków transportu przy przewozie danej jednostki ładunkowej, uzyskuje się duże oszczędności czasu i pieniędzy, a wykorzystanie standaryzowanej wielkości kontenerów likwiduje problem przeładunku towarów z jednego środka transportu na inny (przeładunek polega tylko na przeniesieniu całego kontenera np. ze statku na samochód czy z samochodu na platformę kolejowa). W Europie ta metoda wciąż zyskuje na popularności, gdyż pozwala wykorzystać zalety poszczególnych gałęzi. Obecnie transport intermodalny stanowi $14 \%$ przewozów kolejowych w Starej Unii (UE-15), ale prognozuje się, iż jego udział wzrośnie do $40 \%$ w roku $2020^{21}$. Przewiduje się również, że do tego czasu w transportowych korytarzach Europy pojawi się około $120 \mathrm{mln}$ kontenerów ${ }^{22}$. Niestety, w Polsce transport intermodalny to nadal tylko kilka procent ogólnych przewozów kolejowych.

Odmiana transportu intermodalnego jest tzw. "rolling highways". Polega on na tym, że cały samochód ciężarowy, z przyczepa i kierowca, jest załadowywany na specjalne platformy kolejowe, tak by w momencie dotarcia na miejsce móc jak najszybciej ruszyć w dalszą trasę samochodem. Jest to zwłaszcza praktykowane przy przejazdach przez tunel La Manche lub w krajach alpejskich (zwłaszcza

${ }^{19} \mathrm{~S}$. Miecznikowski (red.), Gospodarowanie w transporcie kolejowym Unii Europejskiej, Wyd. Uniwersytetu Gdańskiego, Gdańsk 2007, s. 62-63.

${ }^{20}$ A. Fularz, Kolej miejska w Łodzi - ratunek dla aglomeracji, za: www.obywatel.org. $\mathrm{pl} /$ index.php? module $=$ subjects\&func $=$ viewpage $\&$ pageid $=594$ [ $z \mathrm{dn} .31 .10 .2009]$.

${ }^{21}$ B. Trochymiak, Dobre czasy dla transportu intermodalnego, za: http://edgp. gazetaprawna. $\mathrm{pl} /$ index. $\mathrm{php}$ ?act $=$ mprasa\&sub $=$ article\&id $=82476$ [z dn. 11.10.2012] .

22 M. Antonowicz, H. Zielaskiewicz, Transport intermodalny jako ogniwo rozwoju kolejowych przewozów towarowych w Unii Europejskiej, za: www.infrastruktura.elamed.pl/ strona-numer-3-2008-21278.html [z dn. 9.01.2010]. 
w Austrii i Szwajcarii, gdzie szczególnie zabiega się o ograniczenie ruchu drogowego) ${ }^{23}$.

Nie sposób nie nadmienić w tym miejscu o rynku operatorów logistycznych, których domena jest transport intermodalny. Podmioty te, działające na zlecenie firm, wykorzystuja transport intermodalny, ponieważ potrafia go sprawnie zorganizować. Przewagę stanowi tutaj nie tylko doświadczenie w branży, ale również zaplecze informatyczne, "które pozwala opanować do perfekcji skracanie czasu dostaw i obniżenie cen usług. Standardem jest wykorzystanie nawigacji satelitarnej GPS do zarządzania flotą samochodowa" ${ }^{24}$ czy programów komputerowych służących planowaniu trasy. Poza tym, w praktyce towarowych przewozów kolejowych należy wskazać takie zjawiska, jak: integracja, konsolidacja i tworzenie powiązań między operatorami, które umożliwiaja korzystanie z zasobów partnera, wspólne realizowanie przedsięwzięć i osiąganie korzyści z efektu synergii25. Rozwój usług dodatkowych (m.in. kompletacja, doradztwo logistyczne, usługi celne) sprawia, iż firmy coraz częściej zawieraja umowy z operatorami logistycznymi, czego następstwem będzie dalszy wzrost przewozów intermodalnych oraz rozwój konteneryzacji i ponowny rozkwit kolei.

\subsection{Znaczenie transportu kolejowego dla Unii Europejskiej}

Unia Europejska posiada najgęstszą sieć transportową na świecie. Biorąc pod uwagę sieć dróg i linii kolejowych, ma znacznie lepiej rozwiniętą infrastrukturę w przeliczeniu na $100 \mathrm{~km}^{2}$ niż Stany Zjednoczone i niewiele gorsza od Japonii26.

Długość linii kolejowych w całej Unii Europejskiej wynosi 215720 km, z czego $44 \%$ jest zelektryfikowana ${ }^{27}$. Obecnie najdłuższa sieć kolejowa posiadaja Niemcy i Francja, odpowiednio 38206 km i 30832 km. W przeliczeniu na 100000 mieszkańców wskaźnik w tych krajach wynosi ok. 50 km, podczas gdy w Niderlandach tylko 17 km. Najgęstszą

${ }^{23} \mathrm{D}$. Lowe, Intermodal freight transport, Elsevier Butterworth-Heinemann, Amsterdam 2005, s. 88.

${ }^{24}$ A. Wiśniewska, Strategia globalna a funkcjonowanie operatorów logistycznych na przykładzie firmy Schenker, [w:] E. Gołembska (red.), Współczesne kierunki rozwoju logistyki, Polskie Wyd. Ekonomiczne, Warszawa 2006, s. 191.

25 M. Antonowicz, H. Zielaskiewicz, Transport intermodalny jako ogniwo rozwoju...

${ }^{26}$ A. Białas-Motyl, Regional road and rail transport networks, s. 1, za: http://epp. eurostat.ec.europa.eu/cache/ITY_OFFPUB/KS-SF-08-028/EN/KS-SF-08-028-EN.PDF [z dn. 11.10.2012].

27 Dane z 2005 r.; A. Białas-Motyl, Regional road and rail.., s. 5. 
siecią kolejową w Unii Europejskiej moga się pochwalić Czechy $\left(122 \mathrm{~km} / 1000 \mathrm{~km}^{2}\right)$ oraz Belgia $\left(116 \mathrm{~km} / 1000 \mathrm{~km}^{2}\right)$. Najmniejsza gęstość sieci to państwa skandynawskie (Finlandia - $17 \mathrm{~km} / 1000 \mathrm{~km}^{2}$, Szwecja - $25 \mathrm{~km} / 1000 \mathrm{~km}^{2}$ ), Grecja (19 km/1000 km²), ze względu na ukształtowanie terenu oraz Estonia i Hiszpania ${ }^{28}$. Średnia gęstość tras kolejowych w UE wynosi $57 \mathrm{~km} / 1000$ km². Duże różnice w wartościach tych wskaźników w poszczególnych państwach członkowskich świadczą o zróżnicowaniu sieci kolejowej w Europie, która, jak już zostało wspomniane wcześniej, powstawała w każdym państwie odrębnie, nakierowana jedynie na potrzeby narodowych gospodarek.

Transport kolejowy Unii Europejskiej od lat boryka się z wieloma problemami:

- państwowe przedsiębiorstwa kolejowe maja problemy finansowe,

- brakuje pieniędzy na modernizację przestarzałej infrastruktury i nowe inwestycje,

- pociągi się spóźniaja, nie kursuja regularnie, jest mało połączeń,

- niezadowolenie klientów z usług kolei pasażerskiej wciąż wzrasta,

- przewoźnicy skarżą się na wysokie ceny i brak możliwości negocjacji warunków umowy,

- kolej przestała być konkurencyjna względem transportu samochodowego.

Między innymi z tych powodów udział towarów przewożonych koleją spadł w latach $1970-1998$ z $21,2 \%$ do $8,4 \%$ (z $283 \mathrm{mld}$ ton/km do $241 \mathrm{mld}$ ton/km) $)^{29}$, a w latach 1995-2004 zatrudnienie w transporcie kolejowym spadło o $21 \%$ w Starej Unii i o $44 \%$ w krajach, które przystapiły do UE 1 maja $2004 r^{30}$

Komisja Europejska w Białej Księdze dotyczącej strategii transportowej do roku $2010^{31}$ określa kolej jako "mix kontrastów”, gdzie obok nowoczesnej szybkiej kolei, która obsługuje pasażerów na wyremontowanych stacjach kolejowych, spotyka się "przedpotopowy" tabor i przestarzała infrastrukturę. Biorąc jednak pod uwagę ogromny potencjał transportu kolejowego oraz istniejace na terenie całej UE zaplecze infrastrukturalne, Unia Europejska w $1991 \mathrm{r}^{32}$ rozpoczęła

28 Dane z 2005 r.; A. Białas-Motyl, Regional road and rail..., s. 4.

29 Patrz również: Komisja Europejska, WHITE PAPER. European transport policy for 2010: time to decide, s. 25, za: http://ec.europa.eu/transport/strategies/doc/2001_ white_paper/lb_com_2001_0370_en.pdf [z dn. 11.10.2012].

30 J. Neider, Transport..., s. 197.

${ }^{31}$ Komisja Europejska, WHITE PAPER. European transport policy for 2010...

32 W tym roku wydana została Dyrektywa nr 440/1991 z dn. 29 lipca 1991 r. w sprawie rozwoju kolei wspólnotowych. Była to pierwsza dyrektywa, która rozpoczynała żmudny proces rewitalizacji kolei w UE. 
proces rewitalizacji kolei, który trwa do dziś. Główne cele, jakie sobie postawiono, to m.in.: rozłączenie funkcji zarządcy infrastrukturą kolejową od prowadzenia działalności przewozowej, dopuszczenie do rynku prywatnych przedsiębiorców, poprawę konkurencyjności w stosunku do transportu samochodowego, dofinansowanie transportu intermodalnego oraz harmonizację przepisów dotyczących interoperacyjności kolei. Poważnym wyzwaniem stała się kwestia, jak przekonać do zrównoważenia wykorzystania poszczególnych gałęzi transportu (którego obecnie brakuje, zwłaszcza w przewozach pasażerskich) przewoźników i osoby prywatne oraz jak lepiej wykorzystać istniejąca sieć transportowa.

Przełomowym dokumentem była Dyrektywa 2001/12/EC, która udostępniła 15 marca 2003 r. 50000 km sieci kolejowej prywatnym licencjonowanym przewoźnikom, którzy od tej chwili mogli rywalizować między sobą w świadczeniu usług przewozowych ${ }^{33}$. Liberalizacja rynku przewozów kolejowych zakończyła się 1 stycznia 2007. Do połowy 2006 r. w krajach członkowskich wydano ok. 700 licencji dla prywatnych przewoźników, najwięcej w Niemczech (338) ${ }^{34}$. Deregulacja rynku przewozów kolejowych niesie wiele korzyści dla użytkowników: konkurencja wymusza poprawę jakości świadczonych usług, wzrost częstotliwości połączeń, ale przede wszystkim spadek cen. Z drugiej strony, prywatni przewoźnicy będą bardziej dbali o infrastrukturę i zabiegali o dofinansowanie różnych projektów związanych z jej rozwojem.

Istotna kwestią dla Jednolitego Rynku Unii Europejskiej była również budowa takiej sieci, która umożliwiałaby transport towarów i pasażerów wewnątrz całej UE, a tym samym wspierała istnienie czterech swobód. Decyzja nr 1692/96 powstał projekt transeuropejskiej sieci transportowej (Trans-European Network Transport, w skrócie TEN-T), na mocy której etapami miała być przeprowadzana „integracja infrastruktury transportu drogowego, kolejowego, autostrad morskich, portów żeglugi morskiej i śródlądowej, transportu lotniczego oraz innych punktów połączeń wewnętrznych między sieciami modalnymi we Wspólnocie"35. Decyzja Parlamentu Europejskiego w sprawie TEN-T przewiduje, iż za sumę ok. 220 mld euro zostanie do 2020 r. zrealizowanych 30 projektów, obejmujących budowę

${ }^{33}$ Komisja Europejska, WHITE PAPER. European transport policy for 2010.., s. 32.

34 J. Neider, Transport..., s. 201.

${ }^{35}$ www.ukie.gov.pl/HLP/files.nsf/0/782f3a4858c8d510c125733900445df2?OpenDocument [z dn. 9.01.2010] 
nowych tras kolejowych, odcinków autostrad, rozbudowę portów itp. ${ }^{36}$ Częścią programu TEN-T jest Transeuropejska Sieć Kolejowa (TransEuropean Rail Freight Network, w skrócie TERFN), która składa się z programów: Transeuropejskiej Sieci Kolei Szybkich Prędkości (TransEuropean high-speed rail network) oraz Transeuropejskiej Sieci Kolei Konwencjonalnych (Trans-European conventional rail network) ${ }^{37}$.

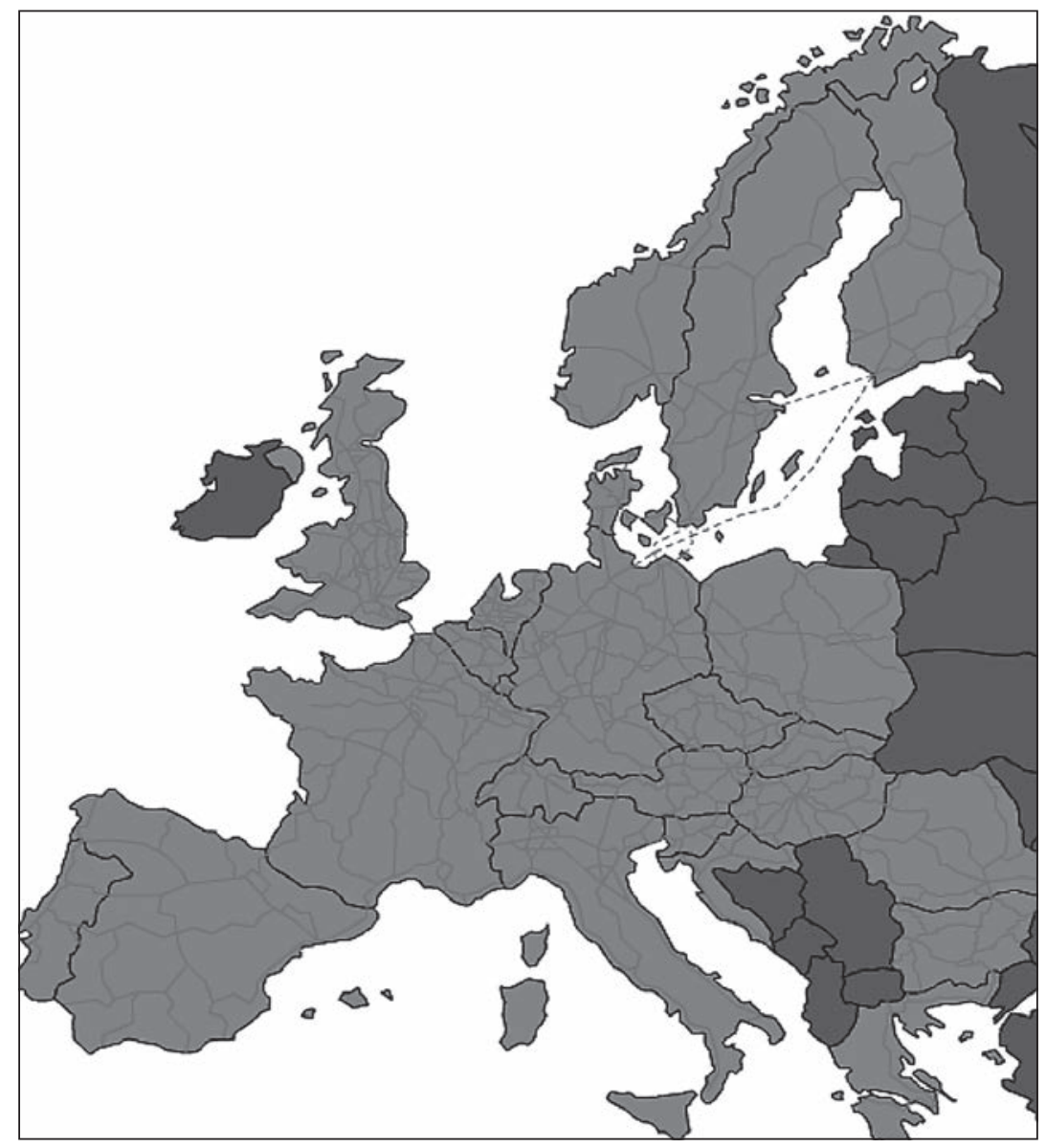

Rysunek 2. Transeuropejska Sieć Kolejowa

Źródło: Country overview map, za: www.rne.eu/index.php/country_overview_map.html [z dn. 11.10.2012]

${ }^{36}$ S. Miecznikowski (red.), Gospodarowanie w transporcie kolejowym..., s. 62

37 http://ec.europa.eu/transport/infrastructure/networks_eu/networks_eu_en.htm [z dn. 9.01.2010]. 
Program TERFN ma doprowadzić do tego, by kolej transeuropejska ${ }^{38}$ :

- przejęła wiodącą rolę w długodystansowych przewozach pasażerskich i krótkodystansowych (poniżej $400 \mathrm{~km}$ ) lotach,

- gdzie to możliwe, przebiegała w pobliżu lotnisk i tworzyła z nimi zintegrowana sieć transportowa,

- łączyła się z koleja regionalną i lokalna,

- zapewniała sprawny transport towarów oraz integrację z transportem samochodowym w celu wykorzystywania zalet obu tych gałęzi,

- odgrywała ważną rolę $w$ transporcie kombinowanym (intermodalnym),

- łączyła się z portami morskimi i śródlądowymi, aby tworzyć z nimi zintegrowany system transportowy.

Unia Europejska, w porozumieniu m.in. z CER i UIC, ustanowiła dla transportu kolejowego następujące cele do zrealizowania do $2020 r^{39}$ :

- wzrost udziału w przewozach pasażerskich z 6 do 10\% i w przewozie towarów z 8 do 15\%,

- potrójny wzrost wydajności pracy osób zatrudnionych w transporcie kolejowym,

- 50-procentowy wzrost efektywności wykorzystania energii oraz

- 50-procentowy spadek emisji zanieczyszczeń.

Czy uda się to osiągną́, zależy nie tylko od działań na szczeblu unijnym, ale przede wszystkim od krajowych decydentów: czy zainwestują w odbudowę i rozwój krajowej sieci i infrastruktury punktowej oraz czy przekonaja przewoźników do zastapienia transportu drogowego transportem kolejowym lub intermodalnym.

Obecnie sytuacja na rynku przewozów kolejowych kształtuje się w następujący sposób: w 2007 r. kolej miała 10,7-procentowy udział w towarowych (ok. 452 mld tonokilometrów) oraz 6,1-procentowy w pasażerskich (ok. 395 mld pasażerokilometrów) przewozach wewnątrz Unii Europejskiej ${ }^{40}$. Udział transportu kolejowego zreszta od wielu lat nie zmienia się w sposób drastyczny, oscylując w granicach $11-13 \%$ w przypadku frachtu oraz 6-7\% w przypadku przewozów pasażerskich. Znaczna dynamikę wykazuja jedynie: transport samochodowy i morski w przewozach towarowych oraz samochodowy i lotniczy w przewozach pasażerskich, co dokładnie ilustrują wykresy 3 i 4.

38 http://europa.eu/legislation_summaries/regional_policy/management/transeuropean_networks/I24094_en.htm [z dn. 11.10.2012].

${ }^{39}$ Komisja Europejska, WHITE PAPER. European transport policy for 2010.., s. 26.

${ }^{40}$ Dyrekcja Generalna ds. Energii i Transportu Komisji Europejskiej, EU energy and transport..., s. 95. 


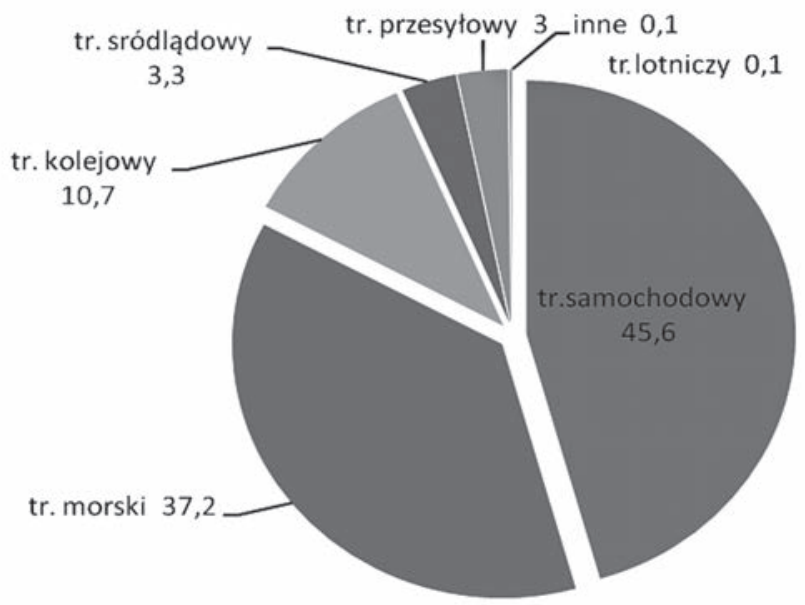

Wykres 3. Udział poszczególnych gałęzi transportu w przewozach towarów wewnątrz Unii Europejskiej

Źródło: opracowanie własne na podstawie: Dyrekcja Generalna ds. Energii i Transportu Komisji Europejskiej, EU energy and transport in figures. Statistical Pocketbook 2009, s. 95

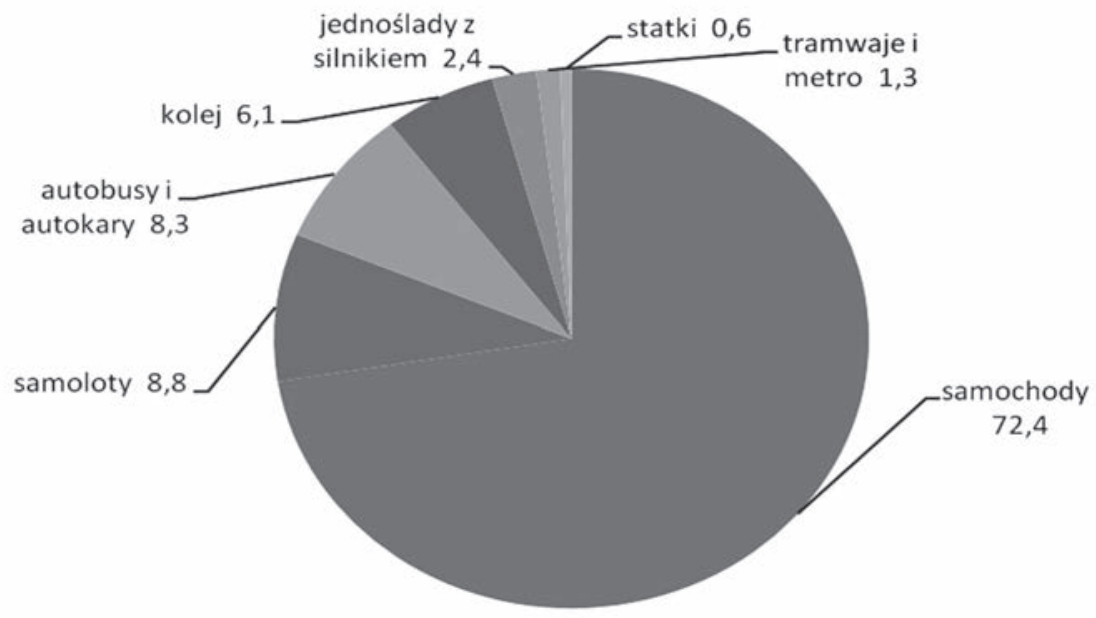

Wykres 4. Udział poszczególnych gałęzi transportu w przewozach pasażerów wewnątrz Unii Europejskiej

Źródło: jak do wykresu 3

W całej Unii Europejskiej w 2006 r. w transporcie kolejowym zatrudnionych było 900000 osób, przy czym najwięcej we Francji (171 500) i w Polsce (120 780). Nadal jednak stanowiło to tylko 10\% ogółu osób 
zatrudnionych $\mathrm{w}$ transporcie (podczas gdy $\mathrm{w}$ transporcie samochodowym odsetek zatrudnionych wynosił aż 52,6\%). Na rynku UE działało wtedy 888 firm w tej gałęzi transportu (aż 239 w Niemczech), które łącznie generowały 78 mld euro. Dla porównania, w tym samym czasie istniało prawie 930000 firm zajmujących się przewozami drogowymi, 10150 transportem morskim i 8800 - śródlądowym ${ }^{41}$. Zaistniała sytuacja to wynik wieloletniej kontroli transportu kolejowego przez państwowe przedsiębiorstwa. Dopiero XXI wiek przyniósł deregulację transportu kolejowego i pojawienie się przewoźników prywatnych.

Tabela 1. Struktura zatrudnienia, ilość przedsiębiorstw oraz ich obrót w poszczególnych gałęziach i sektorach transportu dla całej UE w 2006 r.

\begin{tabular}{|l|r|r|r|}
\hline \multicolumn{1}{|c|}{ Rok 2006 } & $\begin{array}{c}\text { Liczba } \\
\text { zatrudnionych }\end{array}$ & $\begin{array}{c}\text { Liczba } \\
\text { przedsiębiorstw }\end{array}$ & $\begin{array}{c}\text { Obrót } \\
\text { przedsiębiorstw } \\
\text { w mln euro }\end{array}$ \\
\hline Towarowy transport samochodowy & 2832404 & 600000 & 280000 \\
\hline $\begin{array}{l}\text { Pasażerski transport } \\
\text { samochodowy }\end{array}$ & 1840000 & 329758 & 91000 \\
\hline Transport kolejowy & 900000 & 888 & 78000 \\
\hline Transport przesyłowy & 17926 & 131 & 8100 \\
\hline Transport śródlądowy & 43492 & 8800 & 5500 \\
\hline Transport morski & 471440 & 10150 & 90000 \\
\hline Transport lotniczy & 484960 & 3450 & 120000 \\
\hline $\begin{array}{l}\text { Agencje turystyczne i biura } \\
\text { turystyczne }\end{array}$ & 2186726 & 109596 & 384202 \\
\hline $\begin{array}{l}\text { Inne związane z czynnościami } \\
\text { transportowymi }\end{array}$ & 8884010 & 1141000 & 1209995 \\
\hline \multicolumn{1}{|c|}{ RAZEM } & 78227 & 153193 \\
\hline
\end{tabular}

Źródło: opracowanie własne na podstawie: Dyrekcja Generalna ds. Energii i Transportu Komisji Europejskiej, EU energy and transport in figures. Statistical Pocketbook 2009, s. 99-101.

W przewozach poza Unię Europejską, kolej w 2007 r. miała zaledwie 1,7-procentowy udział $w$ eksporcie oraz 1,3-procentowy $w$ imporcie, gdy bierze się pod uwagę wartość towarów oraz odpowiednio 4,6-procentowy i 4,3-procentowy, gdy bierze się pod uwagę tonaż towaru ${ }^{42}$. Tak niski udział wynika z niemożności używania kolei poza kontynentem. Rozbieżność między udziałem wartościowym a tonażem najlepiej obrazuje, że obecnie koleja przewożone sa głównie tanie ładunki masowe, takie jak zboże, węgiel, nawozy czy rudy żelaza.

\footnotetext{
41 Tamże, s. 99-101.

42 Tamże, s. 104.
} 


\subsection{Znaczenie transportu kolejowego w Polsce}

Rozwój kolei w Polsce przypada na XIX wiek. Pierwsza linia kolejowa powstała pomiędzy Wrocławiem a Oławą (rok 1842). Polska była wówczas okupowana przez zaborców, którzy rozwijali sieć kolejową w każdym z zaborów według własnego uznania.

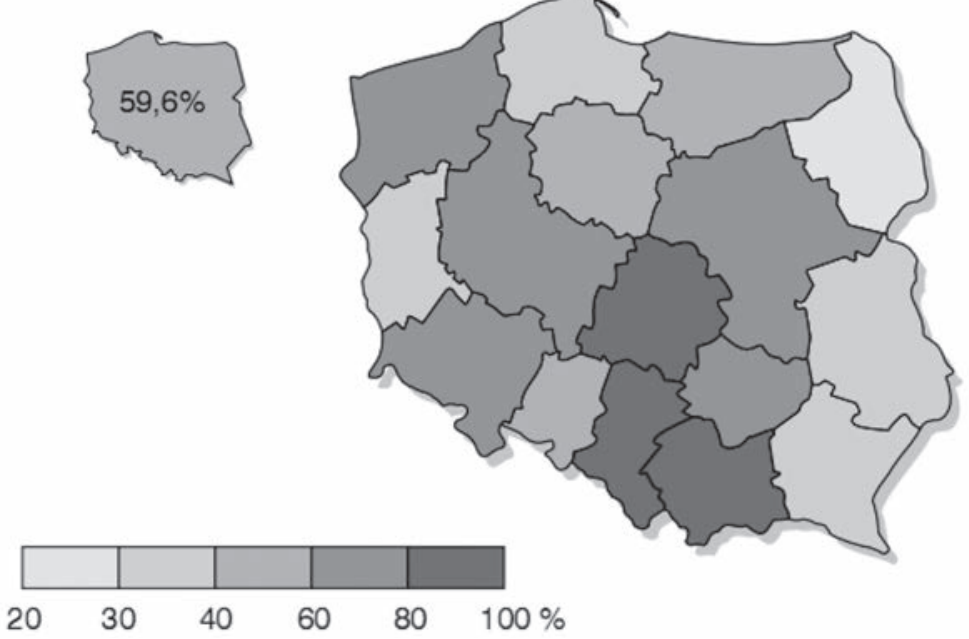

Rysunek 3. Udział linii kolejowych zelektryfikowanych w ogólnej długości linii normalnotorowych eksploatowanych według województw w 2008 r.

Źródło: Główny Urząd Statystyczny, Mały Rocznik Statystyczny Polski 2009, Zakład Wydawnictw Statystycznych, Warszawa 2009, s. 363

Ważnym aspektem oceny sieci kolejowej jest również jej struktura z punktu widzenia kategorii linii. Dane przedstawione poniżej pochodzą z 2002 r., jednak układ ten raczej nie ulega zmianom (następuja co najwyżej drobne przesunięcia między grupami), gdyż są to linie niezbędne dla polskiego systemu transportowego ${ }^{43}$ :

- linie magistralne (najważniejsze w systemie transportowym kraju, o najwyższych prędkościach dopuszczalnych, o przypadajacej największej pracy przewozowej) - 26\% ogólnej długości linii czynnych,

- linie pierwszorzędne (nieco mniejsze znaczenie i dopuszczalne prędkości) - 51\% ogólnej długości linii czynnych.

Razem stanowia one tzw. układ podstawowy polskiego transportu kolejowego. Reszta są to linie drugorzędnego i miejscowego znaczenia.

43 ]. Engelhardt, Infrastruktura transportu kolejowego, [w: ] W. Rydzkowski, K. Wojewódzka-Król, Transport. Problemy transportu w rozszerzonej UE, PWN, Warszawa 2009, s. 71. 
Kolej praktycznie do 1980 r. odgrywała najważniejszą rolę (przewożono nią najwięcej towarów, dominowała również w przewozach pasażerskich) ze względu na mała liczbę środków transportu i niski rozwój infrastruktury pozostałych gałęzi. Proces restrukturyzacji polskiej gospodarki przyniósł głębokie załamania na rynku towarowych przewozów kolejowych - z 286,6 mln ton w 1990 r. do 227,8 mln ton w 1991 r. (czyli o ok. 20\%), a w 1992 r. o kolejne 12\%. Po przyhamowaniu tendencji spadkowej w następnych latach, pod koniec dekady (w latach 1998-1999) nastapiło kolejne załamanie ${ }^{44}$.

W 2008 r. za pomoca kolei przewieziono 248,86 mln ton towarów (lub $52043 \mathrm{mln}$ tonokilometrów). Stanowi to 15\% (mierzone w tonach) lub $18,6 \%$ (mierzone $w$ tonokilometrach) wszystkich przewozów towarowych w Polsce. Dla porównania, samochodami przewieziono 62,4\% (mierzone w tonokilometrach). W 2008 r. koleja podróżowało 28,9 mld pasażerów (20 $389 \mathrm{mln}$ pasażerokilometrów). Procentowy udział kolei w transporcie osób wyniósł 30,1\% (mierzone liczba pasażerów) lub 35,9\% (mierzone $w$ mln pasażerokilometrów) ${ }^{45}$. W Polsce pociagami najwięcej przewozi się węgla (ok. $120 \mathrm{mln}$ ton w 2008 r.), następnie: kamieni i żwiru, ropy i przetworów naftowych oraz metali i wyrobów metalowych. Poświadcza to ogólna tendencję przewożenia kolejami towarów masowych o względnie niskiej wartości.

W sektorze kolejowym w 2006 r. zatrudnionych było 120780 osób, co daje Polsce drugie miejsce pod względem liczby osób pracujących $w$ tej gałęzi ${ }^{46}$. Świadczy to o wciąż dużym znaczeniu kolei w przewozach w kraju albo o niskiej wydajności pracy. Należy pamiętać, że największy kolejowy przewoźnik w Polsce - PKP S.A. - wciąż jest przedsiębiorstwem państwowym, a przez to słabo zarządzanym i kontrolowanym. $Z$ tej samej przyczyny na rynku kolejowym istniały w 2006 r. tylko 92 przedsiębiorstwa, które wygenerowały $3718 \mathrm{mln}$ euro ${ }^{47}$.

Polska kolej podzieliła losy kolei w innych państwach europejskich. Spadek przewozów towarowych przyczynił się do zaniedbań i braku inwestycji infrastrukturalnych. Zaprzestanie wymiany taboru doprowadziło do sytuacji, w której w 2007 r. przeciętny wiek wagonów przekraczał 24 lata ${ }^{48}$. Jakość techniczna infrastruktury jest bardzo zła - tylko $30 \%$ sieci jest dobrej jakości (przez co rozumie się, że wymaga jedynie prac konserwacyjnych). Prowadzi to do sytuacji, gdy na $40 \%$ linii

${ }^{44}$ www.transport-szynowy.pl/index.php?p=wiecej\&id $=42$ [z dn. 21.12.2011].

${ }^{45}$ Główny Urząd Statystyczny, Mały Rocznik Statystyczny Polski 2009, s. 361-362.

${ }^{46}$ Dyrekcja Generalna ds. Energii i Transportu Komisji Europejskiej, EU energy and transport..., s. 99.

${ }^{47}$ Tamże, s. 100-101.

48 J. Engelhardt, Infrastruktura transportu kolejowego, s. 72 
dozwolona prędkość maksymalna to $80 \mathrm{~km} / \mathrm{h}^{49}$. Taka sytuacja zniechęcała przewoźników i pasażerów do korzystania z transportu kolejowego, co dalej nakręcało złą koniunkturę w tym sektorze. Przystapienie Polski do Unii Europejskiej sprawiło, że również w Polsce rozpoczęto proces prywatyzacji i rewitalizacji kolei. Polska kolej została włączona do transeuropejskiej sieci TEN-T i stała się jej wschodnią granica, łączącą kraje UE z Rosją, Ukrainą i Białorusią.

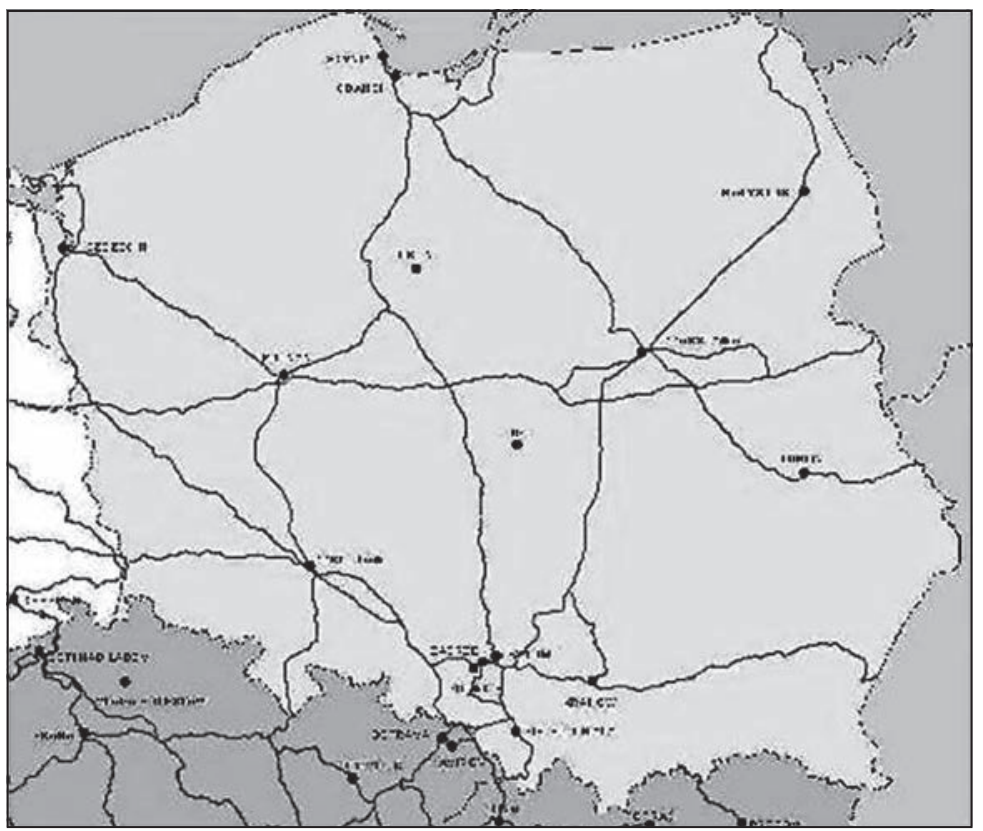

Rysunek 4. Odcinki kolejowe sieci TEN-T w Polsce

Źródło: www.mi.gov.pl/2-4828315ea96e7-3628-p_1.htm

[z dn. 11.01.2010]

Jedną z oznak przemian było częściowe sprywatyzowanie państwowego przedsiębiorstwa kolejowego PKP. W 2001 r. powstała grupa PKP, w której skład weszły pomniejsze spółki, m.in.: PKP S.A. (spółka dominująca), PKP Intercity Sp. z o.o. (przewozy pasażerskie) czy PKP Cargo (przewozy towarowe). "Grupa PKP jest rodzajem grupy kapitałowej, w której spółka dominująca PKP S.A. posiada udziały w spółkach zależnych. Jest jednym z największych polskich pracodawców, zatrudniającym około 125 tys. osób, czwartą co do wielkości koleją europejska. Grupa PKP jest reprezentowana we wszystkich międzynarodowych

${ }^{49}$ OECD, Przeglądy gospodarcze OECD - Polska, t. 2008/10, Instytut Technologii Eksploatacji, Radom 2008, s. 41. 
organizacjach kolejowych"50. Dalsze etapy przemian przewiduja m.in. prywatyzację samej spółki PKP S.A. Prywatni operatorzy moga prowadzić swoją działalność na sieci PKP od 1998 r., na podstawie ustawy z dn. 27 czerwca 1997 r. o transporcie kolejowym ${ }^{51}$, która rozdzielała funkcję zarządcy infrastrukturą od prowadzenia działalności przewozowej. Do połowy lipca 2007 r. wydano 84 licencje - w większości firmom, które przewożą surowce na rynkach lokalnych i które już wcześniej posiadały własny tabor oraz wykonywały przewozy na potrzeby własnej firmy (np. Pol-Miedź Trans, Kopalnia Piasku „Kotlarnia”) 52.

Od 2004 r. Polska ma dostęp do funduszy unijnych w ramach programu TEN-T. Rokrocznie zgłaszane sa projekty budowy lub modernizacji sieci, w tym szlaków kolejowych. W przyszłości, po 2010 r., przewiduje się $\mathrm{m}$.in. budowę 2 linii kolejowych przebiegających przez terytorium Polski: Gdańsk-Warszawa-Wiedeń (projekt 23) oraz Warszawa-RygaTallin (projekt 27) na odcinku od Warszawy do Kowna w ramach tego programu ${ }^{53}$. Inne fundusze, $z$ których Polska korzysta w celu modernizacji kolei to: ISPA/Fundusz Spójności oraz Europejski Fundusz Rozwoju Regionalnego, a także programy: Sektorowy Program Operacyjny - Transport oraz Program Operacyjny Infrastruktura i Środowisko (w ramach którego w latach 2007-2013 ma zostać wybudowanych i zmodernizowanych $1566 \mathrm{~km}$ dróg kolejowych ${ }^{54}$ ). Ważne, by Polska korzystała z nich w pełni, gdyż to jedyna możliwość na duże inwestycje infrastrukturalne, niezbędne „aby Polska zwiększyła mobilność swoich pracowników, poprawiła produktywność i w pełni skorzystała ze swego położenia geograficznego" 155 .

Prowadzone obecnie prace w obrębie infrastruktury kolejowej obejmują m.in. modernizację

- i rozbudowę Warszawskiego Węzła Kolejowego57,

- poznańskiego węzła kolejowego (linia E20),

50 http://www.pkp.pl/grupapkp [z dn. 11.10.2012].

${ }^{51}$ Dz.U. z 1997 r., nr 96, poz. 591.

52 J. Neider, Transport ..., s. 207.

${ }^{53}$ S. Miecznikowski (red.), Gospodarowanie w transporcie kolejowym..., s. 62.

${ }^{54}$ OECD, Przeglądy terytorialne OECD. Polska, Ministerstwo Rozwoju Regionalnego, Warszawa 2008, s. 113.

55 OECD, Przeglądy gospodarcze OECD - Polska, t. 2008/10, s. 40.

56 http://www.plk-inwestycje.pl/prowadzone-modernizacje [z dn. 12.01.2010].

${ }^{57}$ Węzeł ten leży na przecięciu trzech korytarzy paneuropejskich, które maja bardzo istotne znaczenie międzynarodowe: I korytarz: Helsinki-Tallin-Kowno-Warszawa; linia nr 6 (E 75); II korytarz: Berlin-Warszawa-Mińsk-Moskwa; linie nr 2 i 3 (E 20) oraz nr 12 (C-E 20); VI korytarz: Gdańsk-Warszawa-Katowice-Żylina; linie nr 1, 4 i 9 (E 65), na podstawie: www.plk-inwestycje.pl/prowadzone-modernizacje/modernizacjawarszawskiego-wezla-kolejowego [z dn. 12.01.2010]. 
- linii Warszawa-Łódź,

- i rozbudowę linii E75 - Rail Baltica,

- ciaggu transportowego Świnoujście-Szczecin-Poznań-Wrocław-Chałunki (E 59)

- linii E 65/C-E 65, C-E 59, E 30/C-E 30, E 20 i C-E 20, E 75.

Planowana jest również budowa sieci kolei dużych prędkości, o czym bliżej w następnych dwóch rozdziałach.

\section{Podsumowanie}

W wyniku analiz przeprowadzonych w niniejszym rozdziale sformułowano następujące wnioski:

- Rozkwit kolejnictwa, przypadający na druga połowę XIX i pierwsza połowę XX wieku, przyczynił się do rozwoju przemysłu, handlu, formowania się obecnych gospodarek, a także wzrostu mobilności ludności.

- Spadek znaczenia kolei w następnych latach wiąże się z jej licznymi słabościami w porównaniu do innych gałęzi transportu (głównie drogowego).

- Bariery techniczne i brak harmonizacji przepisów utrudniaja przewozy międzynarodowe.

- Opłacalność wykorzystania tej gałęzi transportu rośnie wraz z wydłużaniem tras, jakie maja zostać pokonane.

- W UE transport kolejowy od lat boryka się z tymi samymi problemami, w związku z czym kolej przestała być konkurencyjna wobec transportu samochodowego.

- Przełomem dla kolei w Unii Europejskiej była liberalizacja rynku przewozów.

- Kolejnym ważnym posunięciem dla rozbudowy kolei było stworzenie Transeuropejskiej Sieci Transportowej TEN-T, której elementem jest Transeuropejska Sieć Kolejowa TERFN.

- Polska kolej podzieliła losy kolei europejskich - spadek ilości przewozów pociągnałł za sobą szereg zaniedbań i niedoinwestowania tej gałęzi, przez co obecny stan jej infrastruktury pozostawia wiele do życzenia.

- Szansa dla rozwoju kolei w Polsce stało się udostępnienie funduszy unijnych w ramach programu TEN-T. 



\title{
2. Koleje dużych prędkości
}

\author{
Izabela Andrzejczak-Padarewska*
}

\subsection{Historia kolei dużych prędkości}

W ciągu ostatnich 40 lat, dzięki nieprawdopodobnie szybkiemu postępowi technicznemu, udało się stworzyć pociągi podróżujące szybciej niż kiedykolwiek. Jednak marzenie o szybkim przemieszczaniu się od zawsze tkwiło w umysłach inżynierów. Jak zauważa H. Gliński, „historia kolei na świecie wiąże się nierozerwalnie z ciagłym dążeniem do osiagnnięcia większych prędkości"1.

Bicie rekordów prędkości jest tak stare, jak sama kolej. W 1847 r., na przykład, udało się pokonać lokomotywa parową barierę $100 \mathrm{~km} / \mathrm{h}$, a szczyt możliwości tego rodzaju kolei osiagnnięto w 1938 r., kiedy to brytyjski parowóz Mallard rozpędził się do 202,8 km/h. Należy nadmienić, iż w tym czasie jedna z najlepszych konstrukcji na świecie był polski parowóz Pm36, który zdobył pierwszą nagrodę na światowej wystawie w Paryżu w $1938 r^{2}$

Wraz z nastaniem lokomotyw z napędem elektrycznym pojawiły się nowe możliwości i rozwiązania zwiększające osiągi. Po II wojnie światowej udało się przekroczyć próg $300 \mathrm{~km} / \mathrm{h}$, a w 1988 r. barierę $400 \mathrm{~km} / \mathrm{h}$ - w Niemczech, na linii Fulda-Würzburg ${ }^{3}$. Obecny rekord prędkości kolei elektrycznej, $515,3 \mathrm{~km} / \mathrm{h}$, należy do specjalnie przebudowanego ${ }^{4}$ na potrzeby bicia rekordu pociagu TGV Atlantique, na trasie z Paryża do Le Mans (maj 1990) ${ }^{5}$.

* Mgr Izabela Andrzejczak-Padarewska - Katedra Logistyki, Wydział Zarządzania Uniwersytetu Łódzkiego, ul. Matejki 22/26, 90-237 Łódź.

${ }^{1} \mathrm{H}$. Igliński, Perspektywy rozwoju kolei dużych prędkości w Unii Europejskiej, [w:] E. Gołembska (red.), Współczesne kierunki rozwoju logistyki, Polskie Wyd. Ekonomiczne, Warszawa 2006, s. 118.

2 Tamże.

${ }^{3} \mathrm{~K}$. Towpik, Linie kolejowe dużych prędkości. Stan obecny i kierunki rozwoju wybranych zagadnień z zakresu dróg kolejowych, "Problemy Kolejnictwa” 2002, nr 136, s. 111.

${ }^{4}$ M.in. średnica kół została zwiększona oraz podniesiono napięcie w sieci trakcyjnej na czas przejazdu.

${ }^{5}$ H. Igliński, Perspektywy rozwoju kolei dużych prędkości..., s. 119. 
Takie wyniki osiagaja pociągi podróżujące w systemie koło-szyna. Jeszcze większe prędkości są w stanie rozwiną́ pociągi na poduszce magnetycznej. Nazywane sa "maglev", od słów "magnetic levitaion", gdyż pociągi te, za sprawą oddziaływania pola magnetycznego, niejako lewituja w powietrzu, tuż nad torami ${ }^{6}$.

Przy rozważaniach na temat rekordów prędkości nasuwa się oczywista wątpliwość: czy każda kolej, która porusza się dość prędko, można nazwać "szybką koleja"? Jeśli tak, jaki pułap prędkości uznać za rozgraniczający? A może należałoby wziąć pod uwagę inne czynniki? Czy Polskę, która osiągnęła prędkość 250,1 km/h na trasie Centralnej Magistrali Kolejowej, można uważać za kraj eksploatujący szybkie koleje?

Główny problem polega na zdefiniowaniu określenia "kolej dużych prędkości". Określenia w różnych językach: HST - high speed train, TGV - Train á Grande Vitesse czy Hochgeschwidigkeitzug oznaczaja wszędzie to samo: kolej dużych (wysokich) prędkości. W języku polskim używa się określeń: kolej wielkich prędkości, pociągi dużych prędkości/szybkiego ruchu/superekspresowe lub superekspresy. "Jednak, po pierwsze, szybka kolej może się kojarzyć z Szybką Koleją Miejską w Trójmieście, która do szybkich nie należy, po drugie, jest to określenie zbyt potoczne"7.

Bardziej szczegółową definicję podaje Międzynarodowy Związek Kolei. Według UIC, kolej dużych prędkości charakteryzuje prędkość powyżej $250 \mathrm{~km} / \mathrm{h}$, ale przede wszystkim czynniki wpływające na jakość świadczonych usług przewozowych, takie jak: czas, częstotliwość połączeń oraz komfort podróży. UIC zaznacza, że system szybkiej kolei wymaga:

- specjalnego taboru - dla superekspresu konieczne są specjalne zestawy pociągowe, ze względu na duże jednostkowe zużycie energii elektrycznej czy aspekty techniczne: aerodynamikę, niezawodność, bezpieczeństwo,

- specjalnej dedykowanej linii kolejowej - po zwykłych liniach kolejowych, nawet modernizowanych, można co najwyżej poruszać się z prędkością 200-220 km/h. Odpowiednie ułożenie sieci, skrzyżowań linii, jakość trakcji, dostawa energii czy warunki środowiskowe muszą być spełnione, aby pociągi mogły podróżować z tak znaczną prędkościa,

- specjalnego systemu sygnalizacji - systemy sygnalizacji umieszczane wzdłuż linii kolejowych, przy prędkościach powyżej 200 km/h nie gwarantuja bezpieczeństwa, gdyż moga zostać przeoczone. Niezbędny jest system znajdujący się w kabinie motorniczego.

\footnotetext{
${ }^{6}$ T. Sievert, The world's fastest trains, Capstone Press, Mankato 2002, s. 9.

${ }^{7}$ H. Igliński, Perspektywy rozwoju kolei dużych prędkości..., s. 120.
} 
UIC dodaje, że prędkość 200-220 km/h jest granica wyznaczająca kres zwykłych kolei i początek kolei dużych prędkości ${ }^{8}$, gdyż powyżej tej bariery następuje potrzeba całkowitej przebudowy sieci, z uwzględnieniem wymienionych powyżej czynników.

Za najdokładniejszą uważa się definicję przygotowaną przez Unię Europejska. Dyrektywa 96/48 wyznacza następujące warunki, które musi spełnić system kolei dużych prędkości ${ }^{9}$ :

- infrastruktura, obejmujaca:

- nowe inie kolejowe, odpowiednio wybudowane i przygotowane, przystosowane do prędkości $250 \mathrm{~km} / \mathrm{h}$ i większych,

- istniejace linie kolejowe, zmodernizowane, przystosowane do prędkości przynajmniej $200 \mathrm{~km} / \mathrm{h}$,

- specjalne linie kolejowe dużych prędkości, zmodernizowane bądź wybudowane, przystosowane do cech topograficznych terenu lub specyficznych ograniczeń związanych z obszarami zurbanizowanymi, na których prędkość każdorazowo jest dostosowywana do tych wyjatkowych warunków;

- tabor, który zapewni niezakłócona, bezpieczna i komfortowa podróż:

- na nowych liniach z prędkościa przynajmniej $250 \mathrm{~km} / \mathrm{h}$, a nawet $300 \mathrm{~km} / \mathrm{h}$ w odpowiednich warunkach,

- na liniach zmodernizowanych z prędkością ok. 200 km/h,

- w warunkach specyficznych, z maksymalną prędkością możliwą w danym przypadku;

\section{- dostosowanie infrastruktury $\mathbf{i}$ taboru:}

- koleje dużych prędkości wymagaja najwyższej kompatybilności parametrów infrastruktury z parametrami taboru. Od tej zgodności zależy funkcjonowanie systemu, bezpieczeństwo, komfort podróży, jakość świadczonych usług przewozowych oraz poziom kosztów.

Omawiana dyrektywa pozwala jednoznacznie określić, które połaczenia można zaklasyfikować do linii dużych prędkości.

Historię kolei dużych prędkości rozpoczyna projekt japoński. Pierwszego października 1964 r. Kraj Kwitnacej Wiśni przedstawił światu pierwszy pociąg dużych prędkości - Shinkansen. Nazywa się go również pociaggiem-pociskiem (bullet-train) ze względu na kształt dzioba oraz to, że mknąc po szynach przypomina pędzący pocisk. Pierwszy Shinkansen podróżował ze średnią prędkością $161 \mathrm{~km} / \mathrm{h}$, osiągając maksymalna

${ }^{8}$ Cały powyższy fragment na podstawie: UIC, High speed rail. Fast track to sustainable mobility, s. 2, za: http://www.uic.org/IMG/pdf/2-01_2009_Brochure_high_speed_Jan_2009.pdf [z dn. 1.02.2010].

${ }_{9}^{9}$ Dyrektywa nr 96/48/WE z dn. 23 lipca 1996 r. w sprawie interoperacyjności transeuropejskiego systemu kolei dużych prędkości; Dz.U. L 235 z 17.09.1996. 
wartość 209,2 km/h. Współcześnie pociągi Shinkansen łączą 15 miast japońskich i podróżuja z prędkościa ok. $257,5 \mathrm{~km} / \mathrm{h}^{10}$. Przez 45 lat istnienia skorzystało $z$ tej linii ponad 4 mld osób ${ }^{11}$. Tokaido Shinkansen, z Tokio do Osaki (515 km), jest obecnie najbardziej ruchliwą linią szybkiej kolei na świecie, przewożąc 360 tys. pasażerów każdego dnia12. Powstanie Shinkansen było przełomowym wydarzeniem dla transportu kolejowego. Pierwszy bullet-train pokazał, że kolej nie jest „wymierajaca" gałęzią, ma ogromne możliwości techniczne i komercyjne oraz może spokojnie konkurować z samochodami i samolotami.

Dopiero prawie 20 lat później powstała druga kolej dużych prędkości, tym razem w Europie - we Francji. Lata 90. i początek XXI wieku to rozwój KDP13 na Starym Kontynencie (o czym bliżej w następnym podrozdziale). Poza Europa i Japonią szybkie pociagi podróżuja w USA (od 2000 r.), w Korei Południowej (od 2004 r.), na Tajwanie (od 2005 r.) i w Chinach (od 2008 r.) $)^{14}$.

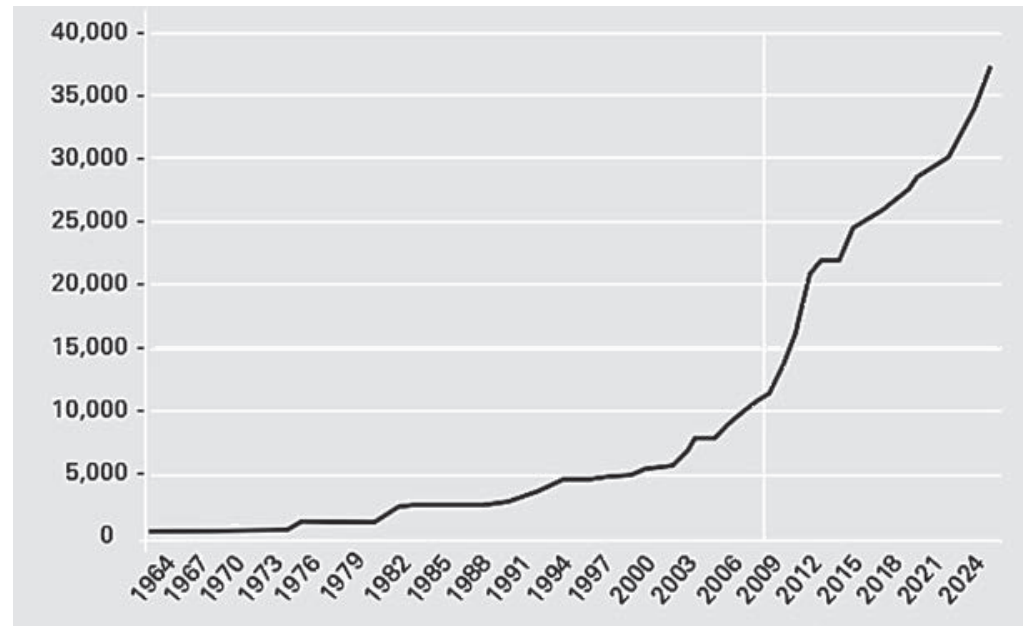

Wykres 5. Rozwój sieci szybkiej kolei na świecie w latach 1964-2024

Źródło: UIC, High speed rail. Fast track to sustainable mobility, s. 11

Obecnie sieć kolei dużych prędkości na świecie liczy ponad 11 tys. km, a liczba ta ma wzrosnąć prawie czterokrotnie do 2024 r. (wykres 5).

${ }^{10}$ G. Roza, The incredible story of trains, PowerKids Press, New York 2004, s. 10.

${ }^{11}$ Należy wspomnieć, iż przez cały ten okres nie doszło do żadnego wypadku, w którym pasażerowie zostaliby ranni (na podstawie: UIC, High speed rail..., s. 5).

12 Tamże.

${ }^{13} \mathrm{KDP}$ - koleje dużych prędkości.

${ }^{14}$ H. Igliński, Perspektywy rozwoju kolei dużych prędkości..., s. 122-131. 
W styczniu 2008 r. w użyciu było 1737 zestawów pociagowych szybkiej kolei (minimalna prędkość $250 \mathrm{~km} / \mathrm{h}$ ) na całym świecie. Ponad 60\% kursowało w krajach europejskich (Francja, Belgia, Niemcy, Włochy, Hiszpania, Wielka Brytania), 427 w Japonii, 163 w Chinach, reszta w Korei, na Tajwanie i w USA (odpowiednio 47, 30, 20) ${ }^{15}$.

Budowa sieci szybkiej kolei oznacza ogromne inwestycje infrastrukturalne. Podróżowanie po krętych torach z tak znaczną prędkościa byłoby niebezpieczne, a pasażerowie odczuwaliby duży dyskomfort (ciągłe hamowanie i rozpędzanie się). Dlatego też tory pod kolej wielkich prędkości są układane z bardzo długich szyn, a tam gdzie tylko to wykonalne, w prostej linii. W celu zachowania drogi w linii prostej odpowiednio przygotowuje się nasypy pod torowisko, buduje mosty, wiadukty i tunele ${ }^{16}$. Jest to szczególnie uciążliwe i kapitałochłonne na terenach górzystych ${ }^{17}$. Często zdarza się, że taką sieć trzeba budować od podstaw, gdyż oprócz układu szyn potrzebne jest inne zasilanie trakcji, występuje konieczność budowy wielopoziomowych skrzyżowań, a system sygnalizacyjny musi z pobocza trasy być „przeniesiony" do kabiny motorniczego. Niezbędne jest również zbudowanie stacji, na których pasażerowie mogliby przesiadać się z superekspresów do zwykłych pociągów, do środków komunikacji miejskiej, samolotów czy samochodów.

Kolej dużych prędkości wymaga również odpowiednich środków transportu. Aby osiągnąć tak znaczne prędkości ${ }^{18}$, inżynierowie m.in. instalują silniki na każdej osi osobno. Wykorzystywanych jest też kilka specjalnych systemów hamulcowych, które będą w stanie zatrzymać "pędzący pocisk". Pojazdy wykonane są z lekkiego, ale wytrzymałego materiału. Ich kształt ma zapewnić zmniejszenie oporów powietrza, a jednolitość zestawu (tzn. pociąg nie jest złożony z odrębnych wagonów) - stabilność i bezpieczeństwo w czasie jazdy. Podwozie takiego pociągu musi być przygotowane na dane obciążenie

15 UIC, High speed rail..., s. 11-12.

${ }^{16}$ D. Biello i in., Bullet trains: inside and out, PowerPlus Books, New York 2002, s. 12.

$17 \mathrm{Z}$ powodu ukształtowania i rzeźby terenu m.in. budowa pierwszej linii kolejowej w Korei Południowej trwała prawie 12 lat, a na Tajwanie trzeba było zbudować najdłuższy wiadukt na świecie (157 km) (na podstawie: H. Igliński, Perspektywy rozwoju kolei dużych prędkości..., s. 124-125).

${ }^{18}$ Szybkość stanowi dla wielu pasażerów największą zaletę. Ch. Maynard w High-speed trains żartobliwie zauważa, że jeżeli marzy się komuś „przejażdżka” pojazdem szybszym niż Ferrari czy Porsche, powinien po prostu wybrać się w podróż pociągiem. Superekspresy poruszaja się tak szybko, iż wydaje się, że sportowe samochody "cofaja się w rozwoju". Nie znajdzie się na świecie policyjnego radiowozu, który dogoniłby szybką kolej, przewożacą w zwykły dzień ludzi z miasta do miasta z prędkościa, bagatela, 229,7km/h (na podstawie: Ch. Maynard, High-speed trains, Wyd. LernerSports, Minneapolis 2002, s. 4). 
(przy $300 \mathrm{~km} / \mathrm{h}$ - 11 do 17 ton na oś ${ }^{19}$ ), prowadzić pojazd gładko po szynach oraz przejmować wszelkie wibracje i trzęsienia, powstałe w wyniku nierówności torów lub kształtu drogi ${ }^{20}$. Co więcej, pociągi takie są wyposażone w różnego rodzaju systemy komputerowe, nawigacyjne oraz sygnalizacyjne.

Pomimo tych kosztów, nawet kraje rozwijające się mają ambitne plany budowy kolei wielkich prędkości, m.in. Tajlandia, Indonezja, Pakistan, kraje Bliskiego Wschodu czy Ameryki Środkowej. Kolej taka oznacza prestiż, nadaje pewną renomę, pokazuje siłę gospodarczą kraju. Oprócz tego zwiększa mobilność ludności, przyciąga inwestycje, przyczynia się do rozwoju turystyki. Szybka kolej to tańszy, bardziej ekologiczny i przyjaźniejszy ${ }^{21}$ substytut samolotów na długich i samochodów na krótkich trasach (na rys. 5 przedstawiono rozwój superszybkich kolei na świecie).

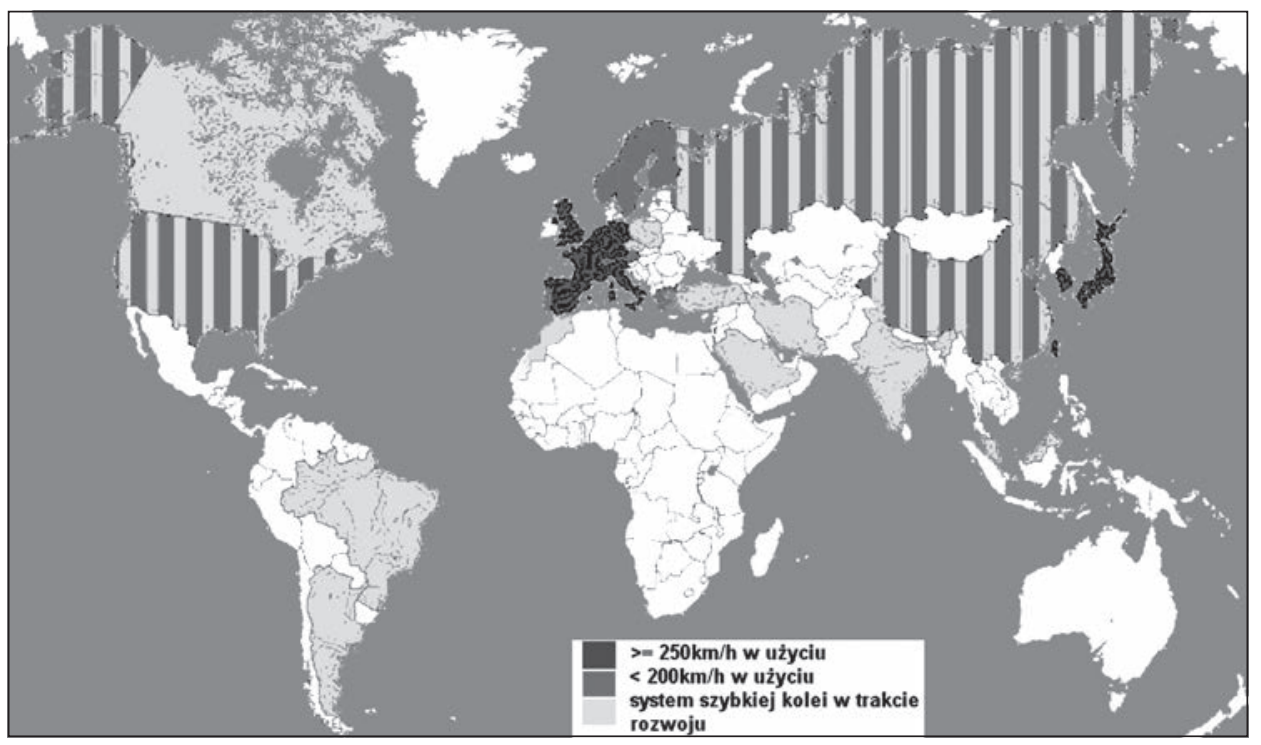

Rysunek 5. Kolej dużych prędkości na świecie (rok 2008)

Źródło: UIC, High speed rail. Fast track to sustainable mobility, s. 23

19 UIC, High speed rail..., s. 12.

${ }^{20} \mathrm{M}$. Hughes, High speed railways options and policy - a world observed, [w:] B. H. North (red.), Modern railway transportation: proceedings of the International Conference "Railways", organized by the Institution of Civil Engineers and held in London on 25-27 May 1993, Redwood Books, London 1993, s. 363.

${ }^{21}$ UIC w swoim raporcie wskazuje, że szybką kolej od samolotów wyróżnia pewna swoboda i wolność: nie trzeba pozostawać na miejscu przez cały czas podróży, nie ma przymusu zapięcia pasów, nie trzeba wysłuchiwać instrukcji bezpieczeństwa i można używać sprzętu elektronicznego (na podstawie: UIC, High speed rail..., s. 6). 
Aby jednak projekt budowy superkolei okazał się sukcesem, muszą być spełnione pewne kryteria22:

- wystarczająco duże zapotrzebowanie, najprawdopodobniej przynajmniej 10 do 15 mln pasażerów rocznie w przewozach między miastami, czas podróży ok. 3 godzin,

- doświadczenie techniczne,

- odpowiednie fundusze - koszty budowy sieci są w dużym stopniu uzależnione od lokalnych warunków geograficznych (np. ile tuneli trzeba będzie zbudować),

- dobre połaczenia ze środkami transportu miejskiego i innymi gałęziami transportu,

- wsparcie polityczne.

W 1993 r., kiedy odbywała się konferencja dotycząca kolei w Londynie, Polska została uznana za państwo na wschodzie Europy, które miałoby największa szansę na budowę szybkiej kolei, łączącej Niemcy z Europa Wschodnią23. W podrozdziale 2.3 zostanie zaprezentowana współczesna koncepcja budowy szybkiej kolei w Polsce i podjęte w tym kierunku inwestycje.

\subsection{Koleje dużych prędkości w Unii Europejskiej}

Proces integracji państw Starego Kontynentu nierozerwalnie wiąże się z nasilająca się chęcią i potrzebą podróżowania po całej Europie w sposób szybki i tani. Alternatywą dla drogiego samolotu i zakorkowanych ulic, której popularność gwałtownie wzrosła już w latach 80. XX wieku, stała się właśnie szybka kolej. Superekspresy miały okazać się również "światełkiem w tunelu" dla samego kolejnictwa: gałąź ta zyskała szansę zmiany wizerunku z przestarzałej i nieefektywnej na kojarzącą się z nowoczesnością, wygoda, wysoką jakością i stosunkowo niską ceną (o ok. 40\% niższą od ceny biletu samolotowego ${ }^{24}$ ). Wspólnota Europejska i jej organy, jako ciało ponadnarodowe, miała prawne i finansowe możliwości doprowadzenia do powstania sieci szybkiej kolei, która "oplatałaby" wszystkie największe miasta Europy i fizycznie wspomagała nadchodząca w niedalekiej przyszłości swobodę przepływu osób.

Komisja Europejska upatrywała w budowie transeuropejskiej sieci szybkiej kolei również ekonomicznych korzyściei

\footnotetext{
22 M. Hughes, High speed railways..., s. 101.

23 Tamże, s. 102.

${ }^{24}$ H. Igliński, Perspektywy rozwoju kolei dużych prędkości..., s. 126.

25 J. F. L. Ross, Linking Europe: transport policies and politics in the European Union,
} 
a) miała być katalizatorem przemian w przemyśle kolejowym, który - wydawało się - zmierzał ku nieubłaganemu bankructwu. Miała stanowić bodziec dla rozwoju istniejacych sieci kolejowych oraz przyczynić się do budowy nowych połączeń międzynarodowych,

b) wprowadziła "zastrzyk" świeżości/nowoczesności do Wspólnego Planu Transportowego, przekształcając jego niestrawny obraz narzuconej polityki promowania kolei za wszelką cenę w rzeczywiście realną i społecznie potrzebna ideę,

c) z szerszej perspektywy - upatrywano w niej kreatora popytu, nowych rynków, a tym samym ogólnego wzrostu i rozwoju całej Wspólnoty, a nawet, jak sugerowały raporty Parlamentu Europejskiego, "poważną broń w walce $z$ bezrobociem".

Dla Wspólnoty promowanie szybkiej kolei to nie tylko kwestia większej prędkości i relatywnie większej efektywności. Pomysł, który zyskał aprobatę społeczeństwa, polityków i ekologów ${ }^{26}$, dawał możliwość przyspieszenia procesów harmonizacji przepisów kolejowych, rozbudowy sieci, unowocześnienia taboru i szybszego egzekwowania ustaleń dotyczących transportu na szczeblu ponadnarodowym.

Pierwsza linia szybkiej kolei w Europie została uruchomiona we wrześniu 1981 r. we Francji, pomiędzy Paryżem a Lyonem. Pociąg, nazwany TGV, podróżował z maksymalną prędkością $260 \mathrm{~km} / \mathrm{h}$ (potem $270 \mathrm{~km} / \mathrm{h}$ ) ${ }^{27}$, w ten sposób skracając czas podróży na tym odcinku $(410 \mathrm{~km})$ z 4 h do 2 h². W kolejnych latach powstawały nowe odcinki trasy szybkiej kolei29:

1989 - TGV Atlantique, łączący Paryż z Le Mans. Planuje się przedłużyć tę trasę w kierunku zachodnim do Renes (TGV Bretagne).

1990 - TGV Atlantique - odgałęzienie do Tours. W przyszłości, prawdopodobnie do 2015 r., linia ta zostanie wydłużona do Bordeaux (TGV Aquitaine), dzięki czemu podróż z Paryża do Bordeaux potrwa zaledwie 2 h i $8 \mathrm{~min}^{30}$.

1993 - TGV Nord-Ouest Europeen z Paryża do Londynu.

1994 - TGV Rhone-Alpes z Paryża do Valence.

1996 - TGV Jonction - wschodnia obwodnica Paryża. Bardzo ważna trasa, która usprawniła ruch pociaggów w węźle centralnym.

Wyd. Praeger, Westport 1998, s. 71.

${ }^{26}$ Chociażby ze względu na fakt, iż szybki pociąg zużywa trzy razy mniej paliwa niż samolot, wykonując tę samą pracę przewozową (na podstawie: H. Igliński, Perspektywy rozwoju kolei dużych prędkości..., s. 142).

27 UIC, High speed rail..., s. 4.

${ }^{28}$ H. Igliński, Perspektywy rozwoju kolei dużych prędkości.., s. 126.

29 Tamże, s. 126-128.

30 J. Raczyński, TGV Mediterranee - piąta linia dużej prędkości we Francji, "Technika Transportu Szynowego" 2001, nr 6, s. 17. 
Dzięki niej pociągi udające się z Brukseli lub Londynu na południe Francji mogły bezkolizyjnie ominąć centrum Paryża.

1997 - TGV Nord-Ouest Europeen - odnoga do Brukseli i dalej do Amsterdamu i Kolonii (razem 332 km długości). Dzięki temu skrócono czas podróży z Paryża do Brukseli do 85 min.

2001 - TGV Mediterranee - przedłużenie TGV Rhone-Alpes do Marsylii i Nimes. Dzięki tej trasie udało się połączyć atlantyckie wybrzeże Francji z południowym nad Morzem Śródziemnym. Budowa TGV Mediterranee zajęła 5 lat i pochłonęła 3,7 mld euro ze względu na trudne warunki naturalne (konieczność budowy wielu mostów i tuneli, z których najdłuższy ma $8 \mathrm{~km}$ ). Istotny jest również fakt, iż w przyszłości planuje się rozbudowę tego ciągu do Włoch i połączenie miast południa Francji z Barcelona, Madrytem, a nawet, przez Niceę i Genuę, z Turynem i Mediolanem.

Podsumowujac, obecnie we Francji istnieje 1569 km systemu sieci kolei dużych prędkości, po którym pociągi moga poruszać się z prędkością $300 \mathrm{~km} / \mathrm{h}$. Do tego należy doliczyć prawie $5900 \mathrm{~km}$ zmodernizowanych linii, na których możliwe jest podróżowanie z prędkością 160, a nawet $220 \mathrm{~km} / \mathrm{h}$. Co więcej, w budowie jest ponad 400-kilometrowa linia łącząca Paryż, przez Metz, ze Strasburgiem (TGV Est-Europeenne). W 2010 r. francuska szybka kolej liczyła 2280 km, z czego 1/3 to sieć najwyższej jakości, na której będzie możliwe poruszanie się z prędkością nawet $350 \mathrm{~km} / \mathrm{h}^{31}$.

Następnym krajem, w którym pojawiły się superekspresy były Niemcy: w 1991 r. powstało połączenie pomiędzy Würzburgiem i Hanowerem oraz pomiędzy Mannheim i Stuttgartem. Siedem lat później oddano do użytku połączenie Berlin-Hanower, gdzie 2/3 trasy stanowiła budowana od podstaw nowa linia. Dzięki temu, że pociągi mogły poruszać się z prędkością $250 \mathrm{~km} / \mathrm{h}$, czas podróży skrócił się do 1 h i $45 \mathrm{~min}^{32}$. Bardzo ważnym etapem w rozwoju niemieckiej szybkiej kolei było otwarcie w 2002 r. linii, która połączyła Kolonię z Frankfurtem i Wiesbaden, ponieważ odcinek ten został przystosowany do prędkości $300 \mathrm{~km} / \mathrm{h}^{33}$.

Znajdujace się w budowie trasy między Norymberga, Ingolstadt a Monachium oraz Mannheim a Stuttgartem również będą dostosowane do prędkości $300 \mathrm{~km} / \mathrm{h}$. W przyszłości szybka kolej ma połączyć Erfurt z Norymberga oraz Kolonię z Brukselą. Do 2010 r. o 50\% wzrosła długość sieci kolei dużych prędkości, z 774 km do ok. 1200 km obecnie. Oczywiście, tak jak w przypadku Francji, sieć ta uzupełniana jest

${ }^{31}$ H. Igliński, Perspektywy rozwoju kolei dużych prędkości.., s. 128.

32 Tamże, s. 128-129.

${ }^{33}$ Koleje DB wchodzą do klubu prędkości 300 km/h, Aktualności, "Technika Transportu Szynowego" 2002, nr 1-2, s. 13. 
o zmodernizowane linie, które umożliwiaja podróżowanie z prędkością 160-230 km/h, jak na przykład między Berlinem a Hamburgiem ${ }^{34}$.

Włochy, choć podjęły budowę sieci szybkiej kolei już w 1970 r., ze względów finansowych i naturalnej bariery w postaci Apeninów ukończyły ja dopiero w 1992 r. Trasa, zwana Diretissima, połączyła Rzym i Florencję. Kolejne odcinki powstały na przestrzeni dekady ${ }^{35}$ : 2005 - po 11 latach budowy otworzono trasę Rzym-Neapol, 2006 - uruchomiona została linia Turyn-Mediolan,

2007 - otworzono dwa odgałęzienia trasy z Mediolanu do Wenecji: Padwa-Wenecja oraz Mediolan-Treviglio,

2008 - dzięki uruchomieniu linii szybkiej kolei Mediolan-Bolonia czas podróży skrócił się z 103 do 65 min, a na trasie z Mediolanu do Rzymu o pół godziny,

2009 - po 13 latach ruszyła trasa Bolonia-Florencja.

W przyszłości planowana jest budowa połączeń pomiędzy Mediolanem a Wenecją i Genua oraz francuskim Lyonem a Turynem. Prowadzone są także przygotowania do zbudowania linii biegnącej z Mediolanu przez Szwajcarię do Niemiec, uwzględniające budowę dwóch tuneli: Gotthard Base Tunnel i Lötschberg Base Tunnel. Pomysł stworzenia odgałęzienia z Triestu do stolicy Słowenii - Lublany ma stanowić bodziec dla rozwoju kolei dużych prędkości we Wschodniej Europie. Natomiast Brenner Base Tunnel ma połączyć niemiecka, austriacką i włoską szybką kolej, tworząc sieć "oplatająca” miasta, takie jak Werona, Innsbruck i Monachium. Ten projekt jest bardzo ważny w Transeuropejskiej Sieci Transportowej, gdyż dzięki niemu powstanie unikatowe połączenie między stolica Niemiec a Palermo na Sycyliij6.

Historia szybkiej kolei w Hiszpanii rozpoczyna się w 1986 r., kiedy rząd podjałł decyzję o zainwestowaniu w nią zamiast w konwencjonalną kolej. W Hiszpanii, w której stolica każdego regionu posiada swoje lotnisko, występuje bardzo wzmożony ruch lotniczy. Rząd uznał, że szybka kolej będzie bardziej ekonomiczną i ekologiczną metodą podróżowania po kraju oraz Europie Zachodniej niż samochód czy samolot. W 1992 r. uruchomiono pierwszą linię szybkiej kolei o długości $471 \mathrm{~km}$ na trasie Madryt-Sewilla. Linia ta została zbudowana w ekspresowo szybkim czasie - tylko 6 lat i po rekordowo niskich kosztach - 1,11 mld euro. W 1997 r. kolej dużych prędkości połączyła Madryt z Barcelona, skracając czas podróży między tymi miastami z 6,5 h do 4. W 2003 r. powstała kolejna linia: Madryt-Lleida, która jest częścia trasy ze stolicy

\footnotetext{
${ }^{34}$ H. Igliński, Perspektywy rozwoju kolei dużych prędkości..., s. 129.

${ }^{35}$ www.railway-technology.com/projects/italy [z dn. 11.10.2012].

${ }^{36}$ Tamże.
} 
do Barcelony oraz do granicy z Francja. W ostatnich latach uruchomiono również szybką kolej na trasie z Madrytu do Toledo oraz często odwiedzanego przez turystów Málaga. Rząd planuje w przyszłości połączyć siecia szybkich kolei wszystkie ważne miasta w południowo-wschodniej Hiszpanii, co więcej, ok. 5 tys. km linii ma być zmodernizowanych i dostosowanych do prędkości $200 \mathrm{~km} / \mathrm{h}^{37}$.

Wielka Brytania dopiero w 2003 r. dołączyła do elitarnego grona państw eksploatujących kolej osiagająca prędkość $300 \mathrm{~km} / \mathrm{h}$, uruchamiając linię CTRL (Channel Tunnel Rail Link). Choć odcinek ten ma zaledwie 64 km długości, to skrócił podróż na trasie Londyn-Paryż do zaledwie 2 h i 35 min, a na trasie Londyn-Bruksela do 2 h i $20 \mathrm{~min}$. Oprócz tego odcinka, Wielka Brytania posiada ponad 1600 km zmodernizowanej sieci kolejowej, która łączy najważniejsze miasta tego kraju, na przykład Manchester, Edynburg czy Glasgow, po których nowoczesne pociągi poruszają się z prędkością do $200 \mathrm{~km} / \mathrm{h}^{38}$.

Belgia i Niderlandy, pomimo iż są to małe kraje, odgrywaja kluczowa rolę na mapie transportowej zjednoczonej Europy, zwłaszcza ze względu na ośrodki władzy unijnej w Brukseli czy Hadze. W Belgii realizowane sa trzy projekty ${ }^{39}$ :

- zachodni - jest to 71-kilometrowy odcinek łączący Brukselę z Paryżem i Londynem. Uruchomiony został w 1997 r., a dopuszczalna maksymalna prędkość to $220 \mathrm{~km} / \mathrm{h}$,

- wschodni - obecnie w budowie, ma połączyć Brukselę z niemiecką Kolonią. W 2002 r. oddano do użytku 61-kilometrowy odcinek pomiędzy Leuven a Ans,

- północny - który ma w znacznym stopniu skrócić czas podróży z Brukseli do Amsterdamu. Od 2005 r. superekspresy kursuja na trasie z Antwerpii do granicy holenderskiej (38 km).

Od września 2009 r. została uruchomiona w Niderlandach HSL-Zuid, czyli Południowa Linia Szybkiej Kolei, która z Amsterdamu, przez lotnisko Schiphol i Rotterdam, biegnie do granicy belgijskiej, gdzie łaczy się z trasa do Antwerpii. Haga i Breda zostały włączone do sieci szybkiej kolei za pomoca zmodernizowanej sieci kolei konwencjonalnej. Planowana jest również HSL-Oost, która połączy Amsterdam, poprzez Utrecht i Arnhem, z Niemcami ${ }^{40}$.

W omówionych powyżej krajach szybka kolej rozwija prędkości 300 km/h. W 2008 r., według danych Komisji Europejskiej, długość

\footnotetext{
37 www.technologyreview.com/microsites/spain/train/p2.aspx [z dn. 11.10.2012].

38 H. Igliński, Perspektywy rozwoju kolei dużych prędkości..., s. 131.

${ }^{39}$ www.belrail.be/E/tgv/tgv.html [z dn. 11.10.2012].

${ }^{40}$ www.railway-technology.com/projects/zuid [z dn. 11.10.2012].
} 
sieci w tych krajach wyniosła 5764 km. Najdłuższa występowała we Francji $(1893 \mathrm{~km})$ oraz Hiszpanii $(1594 \mathrm{~km})$, następnie w Niemczech $(1300 \mathrm{~km})$, we Włoszech $(744 \mathrm{~km})$, w Belgii $(120 \mathrm{~km})$ oraz Wielkiej Brytanii $(113 \mathrm{~km})^{41}$.

Wśród państw, które nie znalazły się w pierwszej grupie, a w których kolej rozwija prędkości 200-220 km/h sa: Szwecja, Finlandia, Dania, Portugalia oraz Grecja. Do 2020 r. we wszystkich tych krajach maja powstać nowe linie, które pozwolą na osiąganie prędkości nie niższej niż $300 \mathrm{~km} / \mathrm{h}^{42}$.

Zestawiając obie te grupy państw, udział szybkiej kolei w ogóle pasażerokilometrów w transporcie kolejowym wzrósł z 15,9\% w 2000 r. do 23,3\% w 2007 r. Należy zwrócić uwagę, że we Francji ponad połowa pasażerokilometrów jest wykonywana właśnie przez superekspresy (2007 r. - 59,7\%). Często z szybkich pociągów korzystają również Szwedzi, Niemcy i Hiszpanie (27-procentowy udział szybkiej kolei w wykonanych przez kolej pasażerokilometrach $)^{43}$.

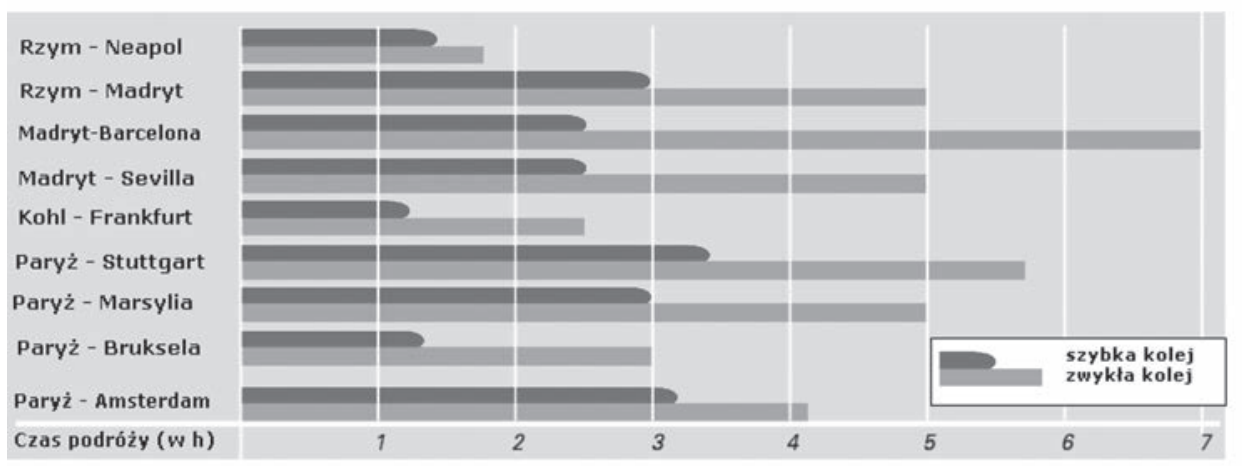

Rysunek 6. Czas podróży koleją konwencjonalną i szybką koleją

Źródło: UIC, High speed rail. Fast track to sustainable mobility, s. 6

Szybka kolej przyczyniła się do "skurczenia się" Europy. Podróżowanie po całej Wspólnocie, praca w innym państwie czy prowadzenie polityki na poziomie unijnym - wszelkie te atrybuty zjednoczonej Europy potrzebowały narzędzia, które "zmniejszy" dystans

${ }^{41}$ Dyrekcja Generalna ds. Energii i Transportu Komisji Europejskiej, EU energy and transport in figures. Statistical Pocketbook 2009, s. 148.

42 Do tego roku superekspresy mają również być eksploatowane w państwach z Europejskiego Obszaru Gospodarczego: w Norwegii i Szwajcarii (na podstawie: H. Igliński, Perspektywy rozwoju kolei dużych prędkości..., s. 133).

${ }^{43}$ Dyrekcja Generalna ds. Energii i Transportu Komisji Europejskiej, EU energy and transport..., s. 124. 
pomiędzy najważniejszymi ośrodkami Unii Europejskiej. Szybka kolej odpowiedziała na tę potrzebę: tańsza od samolotu, wygodniejsza od samochodu, dzięki prędkościom powyżej $200 \mathrm{~km} / \mathrm{h}$ pozwoliła skrócić czas podróży nawet o 64\% (linia Madryt-Barcelona). Europa wydaje się taka mała, biorąc pod uwagę, że ze Stuttgartu do Paryża można dotrzeć w 3,5 h, czyli w tyle, ile samochodem z Łodzi do Krakowa. Na rys. 6 zostało zaprezentowane zestawienie czasu podróży koleją konwencjonalną i koleja dużych prędkości na wybranych trasach.

Wprowadzenie Jednolitego Rynku tylko umocniło w przekonaniu, iż transeuropejska sieć transportowa jest niezbędna dla dalszego rozwoju Unii Europejskiej. Nie dziwi zatem, że w planach UE jest utworzenie do 2015 r. sieci kolei dużych prędkości, która połączy największe miasta Wspólnoty. Do roku 2030 ma powstać około 30 tys. km linii przystosowanych do obsługi szybkich pociągów. Zbudowanie połączeń ekspresowych pomiędzy Londynem, Paryżem, Bruksela, Kolonią i Amsterdamem ma pochłonąc 8,5 mld euro ${ }^{44}$.

Jednak by transeuropejski system był w pełni sprawny, kolej dużych prędkości musi powstać również w krajach przyjętych do UE po 2004 r. Obecnie żaden z nich nie posiada linii dużych prędkości. Zarówno Komisja Europejska (program TEN-T), jak i UIC do 2010 r. nie przewidywały budowy nowych linii, co najwyżej modernizację starych i dostosowanie ich do maksymalnych prędkości $200-220 \mathrm{~km} / \mathrm{h}$. Jest to podyktowane względami ekonomicznymi, gdyż kraje Europy Środkowej i Wschodniej, nawet wsparte funduszami unijnymi, dysponuja zbyt skromnymi środkami, aby zbudować infrastrukturę dla pociagó́w osiagających prędkość powyżej 300 km/h. Główny nacisk zostanie położony na linie leżące $\mathrm{w}$ paneuropejskich korytarzach transportowych.

Należy wspomnieć, iż w Słowenii od 2003 r. na zmodernizowanej linii Wenecja-Lublana-Mariboru pojawiły się włoskie AVE (szybkie pociaggi). Czechy w 2005 r. zakupiły pociagi z wychylnym pudłem, które na wyremontowanych liniach rozwijaja prędkość do 230 km/h. Kursuja one na trasie Praga-Berlin oraz Praga-Bratysława-Wiedeń. Słowacja również jest zainteresowana kupnem takich pociągów, w międzyczasie prowadząc modernizację sieci. Natomiast kraje nadbałtyckie nastawiły się raczej na rozwój transportu towarowego i mało prawdopodobne, aby rządy tych państw zdecydowały się na budowę kolei dużych prędkości ${ }^{45}$.

${ }^{44}$ R. A. Jones, The politics and economics of the European Union: an introductory text, Wyd. Elgar, Cheltenham 2001, s. 337.

${ }^{45}$ Igliński H., Perspektywy rozwoju kolei dużych prędkości.., s. 134. 
Projekt budowy superkolei w Polsce zostanie przybliżony w następnym podrozdziale. Na rys. 7 przedstawiono prognozę europejskiej sieci szybkiej kolei na 2025 r., przygotowaną przez Międzynarodowy Związek Kolejowy - UIC.

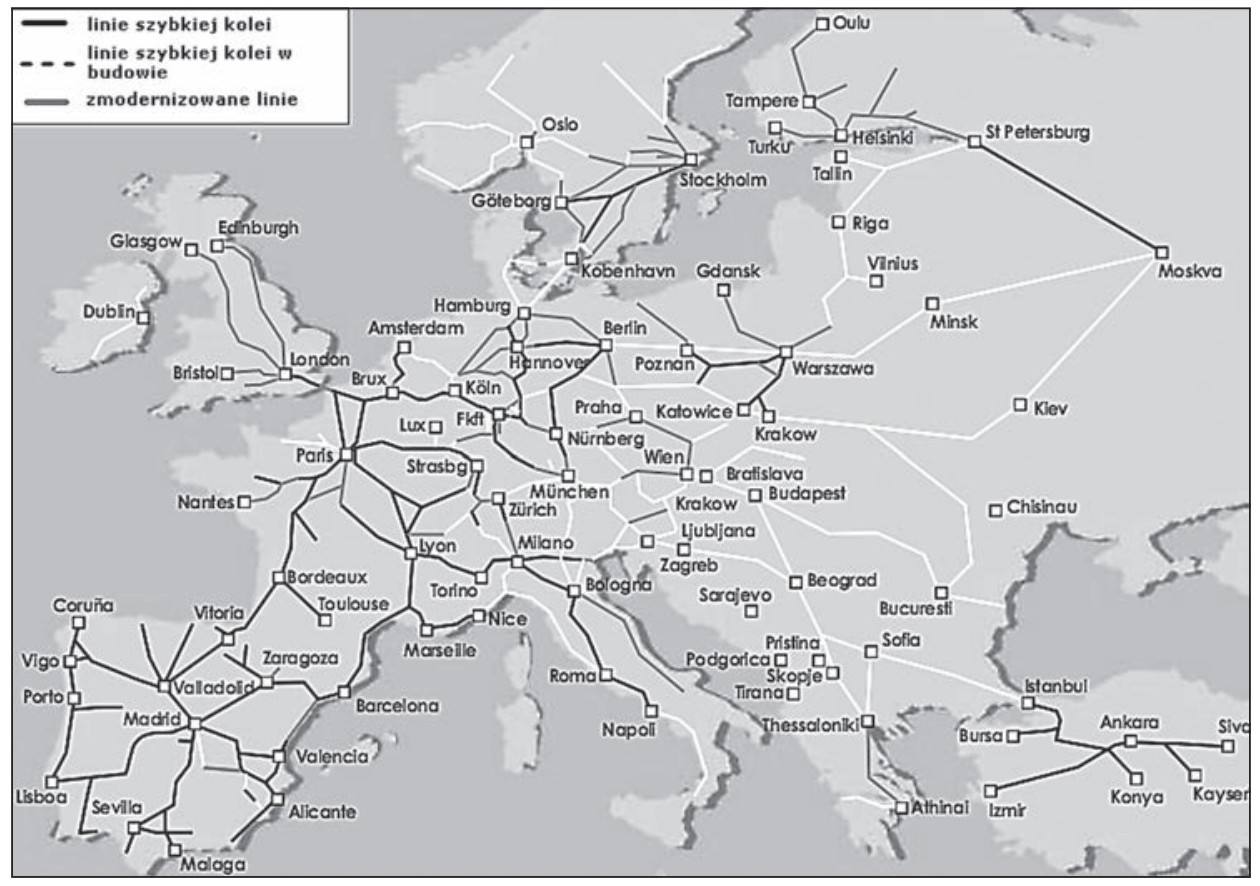

Rysunek 7. Transeuropejska sieć szybkiej kolei - prognoza na 2025 rok

Źródło: UIC, High speed rail. Fast track to sustainable mobility, s. 21

Na zakończenie tego podrozdziału należy dodać, iż rozwój szybkiej kolei wpływa również na rewitalizację miast, przez które przebiega sieć. Wokół nowoczesnych dworców powstaja prestiżowe centra finansowe, handlowe i kulturowe, biurowce, punkty usługowe. Jest to wynikiem współczesnego spojrzenia na planowanie przestrzenne, które zakłada, że dworzec ma być nie tylko miejscem, w którym człowiek przesiada się $z$ jednego środka transportu $w$ inny, ale również obszarem, na którym następuje przestrzenna koncentracja wysokiej jakości działalności gospodarczej, będącej wizytówką miasta i przyczyniającej się do jego rozwoju ${ }^{46}$. Można pokusić się o stwierdzenie, że miasta, przez które będzie przebiegać transkontynentalna sieć szybkiej kolei, urosna do rangi ośrodków o europejskim znaczeniu.

${ }^{46}$ F. Bruinsma, E. Pels i in., Railway developement: impacts on urban dynamics, Wyd. Physica-Verlag, Heidelberg 2008, s. 2. 


\subsection{Projekt budowy kolei dużych prędkości w Polsce}

Polska, ze względu na strategiczne położenie w centrum Europy, posiada ponad 5 tys. km linii kolejowych o międzynarodowym znaczeniu ${ }^{47}$. Niestety, ze względu na zły stan infrastruktury oraz niską jakość świadczonych usług, z roku na rok maleje popyt na przewozy tą gałęzią transportu. Wydaje się, iż w obliczu rozwoju sieci autostrad i dróg ekspresowych w Polsce, które pogorsza jeszcze sytuację przewoźników kolejowych, jedyną szansą dla zrównoważenia transportu jest budowa kolei dużych prędkości. Z tego powodu w 2009 r. resort infrastruktury kierowany przez C. Grabarczyka przygotował ustawę o transporcie kolejowym, która miała przyspieszyć inwestycje. Doświadczenia zachodnich sąsiadów pokazuja, iż rozwój szybkiej kolei i modernizacja sieci konwencjonalnych do prędkości 200-250 km/h może przyczynić się do całkowitej rewitalizacji transportu szynowego. Dzięki skróceniu czasu podróży oraz zwiększeniu komfortu przejazdu taka kolej może konkurować z samochodami czy nawet samolotami. Co więcej, jak pisze A. Żurkowski, "trudno jest sobie dzisiaj wyobrazić funkcjonowanie w Europie nowoczesnego państwa bez sprawnej kolei, w tym stosującej technologię dużych prędkości. Można nawet zaryzykować tezę, że brak takiej kolei - wobec rosnących potrzeb przewozowych społeczeństwa - może stanowić barierę rozwoju społeczno-gospodarczego kraju"48.

Pomysł budowy szybkich połączeń w Polsce nie jest nowy. W latach 70., dla przykładu, podjęto bardzo ważną inwestycję budowy Centralnej Magistrali Kolejowej, prowadzącej z Warszawy na Śląsk, na której można rozwijać prędkości do $250 \mathrm{~km} / \mathrm{h}^{49}$. W 1974 r. powstała notatka dla kierownictwa resortu ${ }^{50}$, w której znalazł się zapis o potrzebie społeczno-gospodarczej utworzenia szybkiego ruchu pasażerskiego pomiędzy stolica a głównymi miastami wojewódzkimi. Natomiast w roku 1984 zorganizowano międzynarodową konferencję poświęconą zagadnieniu szybkiej kolei, z udziałem przedstawicieli UIC oraz kolei

47 Transport infrastructure in ECMT countries: profiles and prospects (monographs), Paris 1998, s. 286.

${ }^{48}$ A. Żurkowski, Duże prędkości - UIC, Polska, "Technika Transportu Szynowego" 2005, nr 5-6 (maj-czerwiec), s. 15.

49 J. Raczyński, A. Massel, Uwarunkowania społeczne i gospodarcze rozwoju kolei dużych prędkości w Polsce, "Technika Transportu Szynowego" 2005, nr 5-6 (maj-czerwiec), s. 29.

${ }^{50}$ Notatka dla kierownictwa resortu w sprawie szybkich pociągów w skali światowej i propozycje w tym zakresie dla PKP, COBiRTK, Warszawa 1975 (lipiec), za: A. Żurkowski, Duże prędkości - UIC, s. 24. 
zachodnich, połączona z wystawa składów TGV i ICE51. Kolejne inicjatywy pojawiły się dopiero w połowie lat 90. XX wieku: w 1994 r. włoski superekspres z przechylnym nadwoziem, Pendolino, ustanowił rekord prędkości na Centralnej Magistrali Kolejowej (250,1 km/h), a w 1995 r., z okazji 75-lecia istnienia Polskiej Kolei Państwowej, przyjechał do Polski pociag TGV $325^{52}$.

W 1996 r. powstała pierwsza spójna wizja w postaci Kierunkowego programu rozwoju linii dużych prędkości w Polsce. Zakładała utworzenie trasy północ-południe w oparciu o istniejaca $\mathrm{CMK}^{53}$. Linia ta miała prowadzić przez Płock na północ do Gdańska oraz na południe do Krakowa i Katowic. Nowa miała być trasa wschód-zachód, biegnąca od granic kraju do Warszawy, a dalej przez Łódź do Poznania. Planowano również powstanie odgałęzienia CMK w Idzikowicach do Wrocławia, prowadzącego przez Piotrków, Bełchatów i Wieluń. Późniejsza modyfikacja tego programu zakładała odgałęzienie linii do Wrocławia od głównej trasy Warszawa-Poznań, jak najdalej od Łodzi, w okolicach Kalisza. Ta propozycja miała być bardziej uzasadniona ekonomicznie niż pierwotna. Ponadto miały być zmodernizowane do prędkości $160-200 \mathrm{~km} / \mathrm{h}$ pozostałe ważniejsze linie kolejowe. Kierunkowy program rozwoju linii dużych prędkości w Polsce zakładał przebieg sieci szybkiej kolei analogiczny do autostrad, a gdzie to tylko możliwe, przeprowadzanie obu tras jednym korytarzem transportowym. Szybkie połaczenia miały funkcjonować od 2030 r. Niestety, nie podjęto dalszych prac związanych z projektowaniem i budowa ${ }^{54}$. Dopiero zdecydowana postawa ministra C. Grabarczyka doprowadziła do przygotowania w 2008 r. studium wykonalności KDP. Rada UE ds. Transportu oraz Parlament Europejski wpisał projekt "trasy Y" do sieci TEN-T.

19 grudnia 2008 r., na mocy uchwały nr 276/2008 Rady Ministrów, przyjęta została ponadregionalna strategia Program budowy $i$ uruchomienia przewozów Kolejami Dużych Prędkości w Polsce ${ }^{55}$. Jest to dokument strategiczny, którego głównym celem jest zaprogramowanie całego przedsięwzięcia budowy szybkiej kolei w Polsce. Program zakłada budowę linii kolejowej wysokich prędkości łącząca Warszawę z Wrocławiem i Poznaniem, nazywana "trasą Y".

${ }^{51}$ ICE - szybka kolej w Niemczech.

${ }^{52}$ A. Żurkowski, Duże prędkości - UIC, s. 23.

${ }^{53}$ CMK - Centralna Magistrala Kolejowa.

54 J. Raczyński, A. Massel, Uwarunkowania społeczne i gospodarcze..., s. 30.

55 Uchwała nr 276/2008 Rady Ministrów z dnia 19 grudnia 2008 r. w sprawie przyjęcia strategii ponadregionalnej - „Programu budowy i uruchomienia przewozów kolejami dużych prędkości w Polsce" (http://www.szybkiekoleje.org.pl/Users/Lena/Desktop/HSR/ www\%20hs-pl\%201\%20dok1.pdf [z dn. 13.01.2010]). 
We wstępnym studium wykonalności, przygotowanym przez Centrum Naukowo-Techniczne Kolejnictwa na zlecenie PKP Polskie Linie Kolejowe S.A., przeanalizowano 7 wariantów przebiegu linii. Warianty od 1 do 3 zakładaja budowę nowych linii kolejowych od podstaw, przystosowanych do prędkości $300-350 \mathrm{~km} / \mathrm{h}$. W wariancie 4 częściowo wykorzystywane sa już istniejące linie, ale nadal z zachowaniem maksymalnych prędkości. Natomiast warianty 5-7 opieraja się na modernizacji już istniejących linii, ewentualnie dobudowie krótkich odcinków uzupełniających ${ }^{56}$. W tych wariantach zakłada się prowadzenie ruchu mieszanego: szybkich pociągów, pociągów towarowych oraz regionalnych pociaggów pasażerskich. Ekspresy po tych trasach mogłyby się poruszać z maksymalną dopuszczalna prędkością $250 \mathrm{~km} / \mathrm{h}^{57}$.

Najkorzystniejsze warianty wybrano na podstawie analizy wielokryterialnej, uwzględniającej następujące aspekty ${ }^{58}$ :

- finansowe (nakłady na inwestycję),

- formalno-prawne (czy projekt wpisuje się w strategiczne cele województw, czy jest zgodny z planami zagospodarowania przestrzennego),

- społeczne (jaką oszczędność czasu można osiągnąć, w jakim stopniu nastapi poprawa bezpieczeństwa, jak budowa wpłynie na kondycję gospodarcza regionów i zatrudnienie),

- środowiskowe (czy linia przechodzi przez obszary objęte programem Natura $2000^{59}$, na jakiej długości potrzebna jest ochrona akustyczna, czy torowisko przebiega nad zbiornikami wodnymi, w jakim stopniu zostanie zanieczyszczone powietrze),

- techniczne (jakie są warunki geologiczne i inżynierskie, jaka jest całkowita długość linii w poszczególnych wariantach),

- transportowe (rozkładowe czasy przejazdu, czy dany wariant pozwoli na usunięcie wąskich gardeł, jaka będzie wielkość potoków, czy uda się włączyć wszystkie ważne ośrodki znajdujące się w obszarze ciążenia linii).

Przeprowadzona analiza wykazała, iż najbardziej korzystne rozwiazzania to warianty 1 i 3 (przy czym wariant 1 występuje w dwóch opcjach). W tab. 2 przedstawiono najważniejsze cechy obu wariantów.

${ }^{56}$ Centrum Naukowo-Techniczne Kolejnictwa, Studium wykonalności budowy linii dużych prędkości Wrocław/Poznań-Łódź-Warszawa. Synteza, s. 5, za: http://szybkiekoleje.org.pl/UserFiles/File/synteza.pdf [z dn. 11.10.2012]

${ }^{57}$ A. Massel, Linia dużych prędkości Wrocław/Poznań-Łódź-Warszawa, „Technika Transportu Szynowego" 2005, nr 12 (grudzień), s. 36.

${ }^{58}$ Centrum Naukowo-Techniczne Kolejnictwa, Studium wykonalności..., s. 6.

59 Natura 2000 - program przygotowany przez Unię Europejską w celu stworzenia wspólnego systemu obszarów objętych ochrona przyrody (na podstawie: http://natura2000.gdos.gov.pl/natura2000/pl/o_obszarach.php [z dn. 11.10.2012]). 
Tabela 2. Najważniejsze cechy wariantu 1 i 3 przebiegu KDP w Polsce

\begin{tabular}{|c|c|c|}
\hline $\begin{array}{c}\text { Cechy przebiegu } \\
\text { linii }\end{array}$ & Wariant 1 & Wariant 2 \\
\hline $\begin{array}{l}\text { Między } \\
\text { Warszawą } \\
\text { a okolicą Zgierza }\end{array}$ & $\begin{array}{l}\text { w korytarzu planowanej } \\
\text { autostrady A2 }\end{array}$ & $\begin{array}{l}\text { w korytarzu planowanej } \\
\text { autostrady A2 }\end{array}$ \\
\hline \multirow[t]{2}{*}{$\begin{array}{l}\text { W okolicach } \\
\text { Łodzi }\end{array}$} & $\begin{array}{l}\text { OPCJA I } \\
\text { północnymi obrzeżami } \\
\text { aglomeracji (na północ } \\
\text { od Zgierza) }\end{array}$ & \multirow[t]{2}{*}{$\begin{array}{l}\text { północnymi obrzeżami } \\
\text { aglomeracji (na północ } \\
\text { od Zgierza) }\end{array}$} \\
\hline & $\begin{array}{l}\text { OPCJA II } \\
\text { wprowadzenie linii do centrum } \\
\text { miasta, tunelem średnicowym } \\
\text { łączácym dworzec Łódź Kaliska } \\
\text { i Łódź Fabryczna }\end{array}$ & \\
\hline $\begin{array}{l}\text { W okolicach } \\
\text { zalewu Jeziorsko } \\
\text { na Warcie }\end{array}$ & na północ od zalewu & na południe od zalewu \\
\hline $\begin{array}{l}\text { Rozgałęzienie } \\
\text { na kierunek } \\
\text { Wrocław } \\
\text { i Poznań }\end{array}$ & w rejonie Kalisza & $\begin{array}{l}\text { w okolicy na północ } \\
\text { od Sieradza }\end{array}$ \\
\hline $\begin{array}{l}\text { Wprowadzenie } \\
\text { do węzła } \\
\text { wrocławskiego }\end{array}$ & $\begin{array}{l}\text { przez Czernicę, Siechnice, } \\
\text { Wrocław Brochów }\end{array}$ & $\begin{array}{l}\text { przez Czernicę, Siechnice, } \\
\text { Wrocław Brochów }\end{array}$ \\
\hline $\begin{array}{l}\text { Wprowadzenie } \\
\text { do węzła } \\
\text { poznańskiego }\end{array}$ & przez Poznań Starołękę & przez Poznań Starołękę \\
\hline
\end{tabular}

Źródło: opracowanie własne na podstawie: Międzyresortowy Zespół ds. Kolei Dużych Prędkości, Program budowy i uruchomienia przewozów kolejami dużych prędkości w Polsce, Warszawa 2008, s. 115-117.

Ostatecznie rozwiązaniem przyjętym przez Radę Ministrów jest wariant 1 opcja II. W uzasadnieniu można przeczytać: „Program KDP ma bardzo istotne znaczenie dla Łodzi. Projektowana w związku z KDP budowa tunelu pod centrum miasta rozwiąże zdecydowanie i jednoznacznie problemy komunikacji kolejowej w węźle łódzkim, w szczególności wynikające z ulokowania miasta na uboczu głównych ciągów linii kolejowych oraz będącego pozostałością historyczną bardzo niefortunnego układu dwóch dworców, praktycznie uniemożliwiającego zorganizowanie zintegrowanej i sprawnej komunikacji kolejowej w regionie"60. Łączna długość linii do wybudowania w ramach wariantu 1

${ }^{60}$ Uchwała nr 276/2008 Rady Ministrów z dnia 19 grudnia 2008 r. w sprawie przyjęcia strategii ponadregionalnej..., s. 5-6. 
opcji II to $540 \mathrm{~km}$. Wicemarszałek Sejmu RP C. Grabarczyk uważa, że pomimo problemów budżetowych, realizacja tych inwestycji nie może być odłożona ze względu na ich znaczenie dla transportu.

Harmonogram prac związanych z budowa KDP przewiduje, że do roku 2011/2012 maja zostać zaprezentowane wyniki wszystkich studiów wykonalności, a w latach 2012-2013 maja być podjęte decyzje lokalizacyjne oraz nastapić wykup gruntów pod trasę linii. Przez trzy lata, od 2012, będa trwały przygotowania dokumentacji projektowej. Prace budowlane maja być podjęte już w 2014 r., by cała linia była oddana do eksploatacji w roku 2019. Od 2018 r., przez dwa lata, będą trwały próby i badania eksploatacyjne, a w międzyczasie (w latach 2014-2019) sukcesywnie zakupywany będzie tabor ${ }^{61}$.

Program budowy KDP w Polsce nieodłącznie wiąże się i uzupełnia Master plan dla transportu kolejowego w Polsce do 2030 roku, który jest dokumentem strategicznym, ukazującym wszystkie aspekty transportu kolejowego w Polsce. Oprócz budowy nowej "trasy Y", przewiduje się modernizację m.in. ${ }^{62}$ :

- CMK na odcinku Zawiercie-Grodzisk Mazowiecki (maksymalna prędkość $250 \mathrm{~km} / \mathrm{h}$, w późniejszym etapie nawet $300 \mathrm{~km} / \mathrm{h}$ ) - do roku 2015,

- odgałęzienia CMK Psary-Kraków (maksymalna prędkość 200 km/h) - do końca roku 2015,

- linii Warszawa-Gdynia (maksymalna prędkość $200 \mathrm{~km} / \mathrm{h}$ ) - do roku 2013,

- linii Poznań-Szczecin (maksymalna prędkość 200 km/h) - do roku 2014,

- linii Warszawa-Białystok (maksymalna prędkość 200 km/h) - do roku 2014.

Co więcej, aby system szybkich połączeń w Polsce działał w pełni sprawnie, konieczne jest ukończenie działań komplementarnych do programu budowy KDP. Wśród takich zadań wymienia się realizację infrastruktury towarzyszącej, jak chociażby przebudowa węzłów kolejowych, budowa lub modernizacja dworców czy stworzenie odpowiedniego zaplecza techniczno-obsługowego. KDP powinna zostać również odpowiednio skomunikowana z centralnym portem lotniczym oraz powinny być zagwarantowane drogi dojazdowe do stacji obsługi pasażerów

${ }^{61}$ B. Ciszewski, Program budowy i uruchomienia przewozów kolejami dużych prędkości w Polsce, prezentacja, slajd 14, za: www.konwent.lodzkie.pl/images/05 PKP PLK Lodz 16-04-2009.pdf [z dn. 11.10.2012].

62 Międzyresortowy Zespół ds. Kolei Dużych Prędkości, Program budowy i uruchomienia przewozów kolejami dużych prędkości w Polsce, Warszawa 2008, s. 8. 
szybkiej kolei. Ważnym zadaniem jest również skompletowanie kadry do projektowania, budowy i eksploatacji KDP63.

Według szacunków, nakłady poniesione na prace przygotowawcze oraz inwestycyjne wyniosą: ok. $22 \mathrm{mld}$ zł na infrastrukturę (i będą ponoszone od 2008 do 2020 r.) oraz 3,2 mld zł na zakup taboru. Te same szacunki podaja, że, przy optymistycznych założeniach dotyczących cen projektowania oraz budowy, jak i eksploatacji i utrzymania, a także przyjmując cenę biletu na aktualnym poziomie analizy (średnia cena biletu netto na poziomie 81-87 zł w latach 2020-204164), uda się uzyskać zerowy wynik projektu do $2041 \mathrm{r}^{65}$ Inwestycja zostanie sfinansowana w $75 \%$ przy pomocy kredytu z Europejskiego Banku Inwestycyjnego, a w $20 \%$ z funduszy Unii Europejskiej. Polska może również pozyskać środki z Banku Światowego, emitując obligacje lub/oraz angażując w projekt prywatnego inwestora ${ }^{66}$. Resort ministra C. Grabarczyka dopuszczał także możliwość budowy KDP w partnerstwie publiczno-prywatnym. Natomiast szacunkowy koszt budowy wynosi ok. $18 \mathrm{mld}$ zł.

Projekt budowy KDP w Polsce cieszy się ogromnym poparciem zarówno ze strony społeczeństwa, jak i polityków, inżynierów czy przedstawicieli międzynarodowych organizacji (np. UIC) i zagranicznych kolei ${ }^{67}$. Dzięki tej inwestycji w znacznym stopniu zwiększy się dostępność transportowa miast włączonych do sieci, ale również regionów położonych na tzw. ścianie wschodniej, terenów Polski zachodniej, nie tylko w relacjach z Warszawa. Szczególnie należy zwrócić uwagę na naturalne przedłużenia linii KDP:

- z Poznania do Szczecina, do granicy państwa i dalej do Berlina,

- z Warszawy do Białegostoku, Lublina, Gdańska czy do Terespola i dalej do Moskwy,

- z Krakowa do Rzeszowa, a dalej do Lwowa i Kijowa,

- $z$ Łodzi do Opoczna68.

Te połączenia przedstawiono na rys. 8 , wskazujacc, w jaki sposób można komplementarnie wykorzystywać kolej konwencjonalną

${ }^{63}$ Uchwała nr 276/2008 Rady Ministrów z dnia 19 grudnia 2008 r. w sprawie przyjęcia strategii ponadregionalnej..., s. 9.

64 J. Raczyński, Rządowy program budowy linii dużych prędkości w Polsce, „Technika Transportu Szynowego" 2008, nr 9 (wrzesień), s. 25.

${ }^{65}$ Międzyresortowy Zespół ds. Kolei Dużych Prędkości, Program budowy i uruchomienia przewozów..., s. 9.

${ }^{66}$ Tamże, s. 67.

67 J. Raczyński, A. Żurkowski, Koleje dużych prędkości w Europie i projekty budowy nowych linii w Polsce, "Technika Transportu Szynowego" 2006, nr 4 (kwiecień), s. 72.

${ }^{68}$ Międzyresortowy Zespół ds. Kolei Dużych Prędkości, Program budowy i uruchomienia przewozów..., s. 32. 
i szybką kolej. Należy w kwestii dostępności dodać, iż zwiększy się liczba pociągów kursujących na wyżej wspomnianych trasach. Zakłada się na przykład, że superekspresy będą podróżowały z Warszawy do Poznania co godzinę, w szczytowym okresie dnia nawet co 30 min (na przemian Warszawa-Szczecin oraz WarszawaBerlin), podobnie w przypadku połączenia Warszawa-Łódź, natomiast pociaggi linii Warszawa-Łódź-Wrocław oraz Kraków-ŁódźPoznań-Szczecin co 2 godziny ${ }^{69}$.

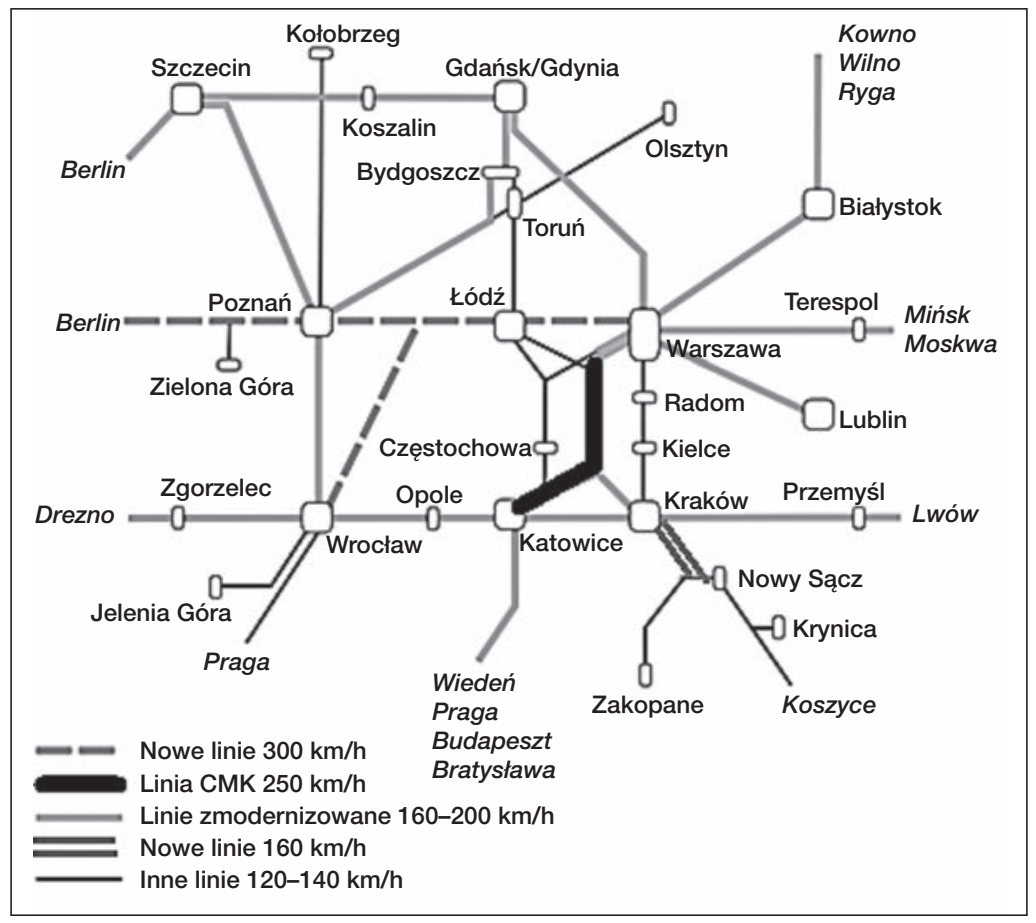

Rysunek 8. Optymalny układ połączeń między głównymi miastami Polski i krajami ościennymi

Źródło: J. Raczyński, A. Massel, Uwarunkowania społeczne i gospodarcze rozwoju kolei dużych prędkości w Polsce, "Technika Transportu Szynowego" 2005, nr 5-6 (maj-czerwiec), s. 33

Dzięki superekspresom w znacznym stopniu skróci się czas podróży pomiędzy największymi miastami Polski. Przejazd z Warszawy do Łodzi obecnie trwa 1 h 30 min, a po zakończeniu inwestycji wyniesie 45 min. Ekstremalnemu skróceniu ulegnie czas podróży z Białegostoku

${ }^{69}$ A. Massel, Linia dużych prędkości..., s. 40. 
do Wrocławia: z 8 h 30 min do 3 h 15 min, co oznacza, iż pociagiem będzie można dotrzeć na miejsce dwa razy szybciej niż samochodem. Na nowej linii Warszawa-Poznań czas podróży ulegnie tak znacznemu skróceniu, iż koleja dotrze się szybciej nie tylko w porównaniu z transportem samochodowym, ale również lotniczym (KDP - 1 h 30 min, transport drogowy - 4 h 30 min, lotniczy - 2 h 55 min $)^{70}$.

Budowa szybkiej kolei w Polsce pozwoliłaby również skrócić czas podróży z Warszawy do wybranych stolic europejskich w następującym wymiarze: do Berlina o połowę (z 370 do $185 \mathrm{~min}$ ), do Pragi o $32 \%$ (z 555 do $380 \mathrm{~min}$ ) i do Wiednia o 40\% (z 490 do $295 \mathrm{~min})^{71}$. Ponadto, powinna ona zapewnić dogodniejsze połączenia w kierunku północnowschodnim (Ryga, Tallin, Kowno), wpisując się w międzynarodowe projekty, takie jak E 30, E 59, E 7572. We wrześniu 2009 r. C. Grabarczyk poinformował, że planuje się rozbudowę KDP także w kierunku Gdańska, przez Lublin i Zamość na Ukrainę.

Tak istotne zmiany $w$ długości trwania oraz jakości podróży, jak również zastosowanie najnowszych technologii i technik, pozwola zmienić wizerunek transportu kolejowego w Polsce i przyczynia się do wzrostu udziału tej gałęzi w ogólnych przewozach. Więcej pasażerów będzie oznaczało większe zyski dla przewoźników, a tym samym większe możliwości inwestycyjne w celu dalszego doskonalenia świadczonych usług.

Szybka kolej przyczyni się także do wzrostu spójności gospodarczej, społecznej i przestrzennej państwa (co jest szczególnie ważne w przypadku Wrocławia, a pośrednio Szczecina i Zielonej Góry). Włączenie się Polski do transeuropejskiej sieci kolei dużych prędkości zapewni lepszą współpracę kulturowa, społeczną i gospodarczą euroregionów. Należy również zaznaczyć, iż dzięki KDP nastąpi znaczna poprawa bezpieczeństwa w transporcie, zarówno przez wykonywanie przewozów koleja, której stopień bezpieczeństwa jest bezkonkurencyjny, jak i przez ograniczenie potrzeby przemieszczania się transportem indywidualnym. Ten ostatni aspekt ma również ogromne znaczenie w kwestii ograniczania negatywnych skutków transportu dla środowiska (zwłaszcza emisji dwutlenku węgla) ${ }^{73}$.

Budowa kolei dużych prędkości to, jak już zostało wspomniane, wielka szansa dla miast i aglomeracji, przez które ona przebiega: stanowi poważny atut gospodarczy regionu oraz stwarza nowe perspek-

${ }^{70}$ Międzyresortowy Zespół ds. Kolei Dużych Prędkości, Program budowy i uruchomienia przewozów..., s. 39-40.

${ }^{71}$ A. Żurkowski, Duże prędkości - UIC, s. 24.

${ }^{72}$ Centrum Naukowo-Techniczne Kolejnictwa, Studium wykonalności..., s. 25.

${ }^{73}$ Międzyresortowy Zespół ds. Kolei Dużych Prędkości, Program budowy i uruchomienia przewozów..., s. 7. 
tywy rozwoju. Nie dziwi zatem, iż miasta podjęły między sobą wyścig o bycie włączonym do sieci. Prezydenci Łodzi, Wrocławia i Poznania już w 2006 r. podpisali porozumienie o współpracy w celu realizacji tego projektu, największego i najambitniejszego od czasów budowy Kolei Warszawsko-Wiedeńskiej w XIX wieku ${ }^{74}$.

\section{Podsumowanie}

W wyniku analiz przeprowadzonych w niniejszym rozdziale można sformułować następujące wnioski:

- Nowoczesne elektryczne pociągi potrafia osiagać ponad dwukrotnie większe prędkości niż najszybsze kolejki z napędem parowym.

- Precyzyjne określenie, czym są koleje dużych prędkości, okazuje się problematyczne, jednak powstał szereg wymagań, które pozwalaja doprecyzować to zagadnienie.

- Powstanie kolei dużych prędkości było jednym z czynników powodujących zmianę wizerunku kolejnictwa z przestarzałego i nieefektywnego na kojarzące się z nowoczesnościa, wygoda, wysoką jakością i stosunkowo niską cena.

- Rozwój szybkiej kolei na świecie, z roku na rok, jest coraz bardziej dynamiczny.

- Wiele państw Unii Europejskiej już korzysta z szybkiej kolei, a inne sa na etapie przygotowania do jej wprowadzenia.

- Dla Polski rozwój kolei dużych prędkości świadczy o nowoczesności i poziomie rozwoju gospodarczego kraju. Przyczynia się do zwiększenia spójności i jest katalizatorem zmian. Dzięki sprawnej kolei będa mogły się tworzyć silne więzi społeczne i gospodarcze między regionami, nawet bardzo od siebie odległymi, co wpłynie na pobudzenie przedsiębiorczości i wzrost mobilności ludności.

- Analizy państw, w których istnieje szybka kolej wskazuja, iż pozytywnie oddziałuje ona na modernizację państwa i zwiększenie jego atrakcyjności inwestycyjnej.

74 J. Raczyński, A. Żurkowski, Koleje dużych prędkości w Europie.., s. 72. 



\section{Tunel średnicowy $w$ Łodzi ważnym elementem projektu kolei dużych prędkości}

Izabela Andrzejczak-Padarewska*

\subsection{Historia łódzkiego węzła kolejowego oraz jego znaczenie na mapie transportowej Europy}

Łódź, trzecie miasto pod względem liczby ludności w Polsce ${ }^{1}$, posiada cechy świadczące o ponadnarodowym charakterze tego ośrodka. Utrzymuje intensywne kontakty zagraniczne poprzez instytucje i przedsiębiorstwa, które zajmuja się handlem, organizacją festiwali, targów czy kongresów. Co więcej, współpracuje i wciąż nawiązuje nowe kontakty z miastami partnerskimi. Jednak, z drugiej strony, w mieście nie znajduja się siedziby międzynarodowych korporacji czy instytucji, brak również rozwiniętego sektora usług oraz mass mediów o zasięgu ponadregionalnym. Bolączką miasta jest również słabo rozwinięta infrastruktura transportowa: brak obwodnicy, systemu autostrad, rozwiniętej sieci kolejowej czy lotniska o znaczeniu międzynarodowym. W ostatnich latach nastapiła jednak odczuwalna poprawa w tym zakresie. Jest to efekt $m$.in. dostępu do licznych funduszy UE oraz skutecznego ich pozyskiwania, dobrej współpracy między łódzkim samorządem a władzami centralnymi, a także licznych umów podpisanych w latach 2007-2011 (za kadencji ówczesnego ministra infrastruktury C. Grabarczyka) na modernizację infrastruktury transportowej w Polsce, w tym także w województwie łódzkim². Ze względu na przemysłowa przeszłość i brak odpowiedniej promocji Łódź nie cieszy się dużym zainteresowaniem turystów zarówno krajowych, jak i zagranicznych. Te cechy powodują, iż w analizie Uwarunkowania i szanse rozwoju polskich metropolii ${ }^{3}$,

* Izabela Andrzejczak-Padarewska - Katedra Logistyki, Wydział Zarządzania Uniwersytetu Łódzkiego, ul. Matejki 22/26, 90-237 Łódź.

${ }^{1}$ Według danych z 30 czerwca 2009 r. liczba ludności w Łodzi wynosi 744541 (na podstawie: www.stat.gov.pl/cps/rde/xbcr/gus/PUBL_L_ludnosc_stan_struktura_30_06_2009.pdf [z dn. 15.04.2010]).

2 Zob. m.in. www.transport.gov.pl/2-482b057d85677-1794697.htm [zdn. 25.02.2013].

${ }^{3}$ B. Jałowiecki, Uwarunkowania i szanse rozwoju polskich metropolii, Departament Koordynacji Polityki Strukturalnej, MGPiPS, www.mpips.gov.pl, na podstawie: 
przygotowanej dla Departamentu Koordynacji Polityki Strukturalnej, w porównaniu z innymi miastami (o mniejszej liczbie ludności), Łódź zajmuje odległe 6 miejsce. W dokumencie tym, oceniającym potencjał poszczególnych metropolii oraz uwarunkowania zewnętrzne, stwierdzono, że Łódź, na tle całej szóstki, ma najmniejsze szanse rozwoju4.

Jedną z przyczyn takiej oceny, jak już zostało wspomniane, jest brak spójnej i odpowiedniej infrastruktury kolejowej. Województwo łódzkie charakteryzuje się stosunkowo niską gęstością linii kolejowych: 59 km na $1000 \mathrm{~km}^{2}$ powierzchni, przy średniej krajowej na poziomie $65 \mathrm{~km}^{5}$. W Łodzi jest 20 stacji i przystanków kolejowych, jednak większość jest niewykorzystywana lub nieczynna. Dwa najważniejsze dworce to: czołowy - Łódź Fabryczna i przelotowy - Łódź Kaliska, których potencjał również nie jest wykorzystywany w pełni. Aby zrozumieć specyfikę węzła łódzkiego, należy prześledzić jego historię, która pokrótce została przedstawiona poniżej.

Już w czasie zaborów Łódź powinna być postrzegana jako atrakcyjny punkt na mapie kolejowej Polski ze względu na rozwijający się tutaj przemysł włókienniczy. Pierwsza okazja włączenia Łodzi w sieć kolejową nadarzyła się przy budowie linii Warszawa-Wiedeń. Wydawało się logiczne, że w celu uzyskania najefektywniejszego (najlepszego) połączenia, należałoby przeprowadzić trasę przez Łódź. Niestety, ówczesne władze, zapewne obawiając się umocnienia pozycji tego miasta, w którym Żydzi stanowili spory odsetek społeczeństwa, zdecydowały inaczej. Kolej przebiegła z dala od ważnego ośrodka gospodarczego, przez małe miejscowości, w których ówczesne władze często wypoczywały. Łódź miała być obsługiwana przez stację Rokiciny, do której wybudowano nową drogę. Miasto podejmowało kolejne próby uzyskania połączenia kolejowego poprzez staranie się o pozwolenie na budowę linii Rokiciny-Łódź-Kalisz oraz o włączenie w planowana trasę Warszawa-Bydgoszcz. Pomysłem władz miasta było, aby linię warszawsko-bydgoską wydłużyć w kierunku Łodzi, prowadząc ją ze stacji Rokiciny, przez Łódź i Zgierz, do obecnego przebiegu tej trasy. Zwiększony koszt inwestycji miał być zrekompensowany wyższymi wpływami ze sprzedaży biletów w przyszłości. Niestety, władze centralne i tym razem podjęły decyzję o ominięciu Łodzi, tworząc połączenie Warszawa-Skierniewice-Łowicz-Kutno-Bydgoszcz ${ }^{6}$.

W 1864 r. udało się uzyskać zgodę na przyłączenie do Kolei Warszawsko-Wiedeńskiej, jednak bez możliwości przedłużenia trasy

A. Drożyńska i in., Przesłanki rozwoju Łodzi jako ośrodka przemysłowego i centrum handlu międzynarodowego, Łódzkie Towarzystwo Naukowe, Łódź 2004, s. 69.

${ }^{4}$ Tamże, s. 69-70.

5 Tamże, s. 113.

${ }^{6}$ R. Piech, Historia węzła Łódź, za: www.inforail.pl/text.php?from =search\&id=16435 [z dn. 11.10.2012]. 
do Kalisza (tzw. Droga Żelazna Fabryczno-Łódzka). Stacja styczną została w efekcie stacja obecnie znana jako Koluszki. Cała trasa budowana była bardzo ekonomicznie, wykorzystując pochyłości terenu. Największe inwestycje dotyczyły przebudowy centrum Łodzi, gdzie torowisko poprowadzono nasypem, aby w przyszłości istniała możliwość wydłużenia trasy do Kalisza. Łódź Fabryczna stała się dworcem przelotowym, następnie trasa prowadziła mostem nad ulicą Kilińskiego i nasypem aż do ulicy Sienkiewicza. Linia ta okazała się bardzo dochodowa, do tego stopnia, że wnet Łódź stała się wąskim gardłem, bo ilość towarów przewyższała możliwości układu torowego, jak również posiadanego taboru. W 1885 r. przewoźnik zdecydował się na dokupienie taboru oraz budowę bocznej linii towarowej okalającej miasto, prowadzącej od stacji Łódź Widzew w kierunku jeszcze wtedy nieistniejącej stacji Łódź Kaliska?.

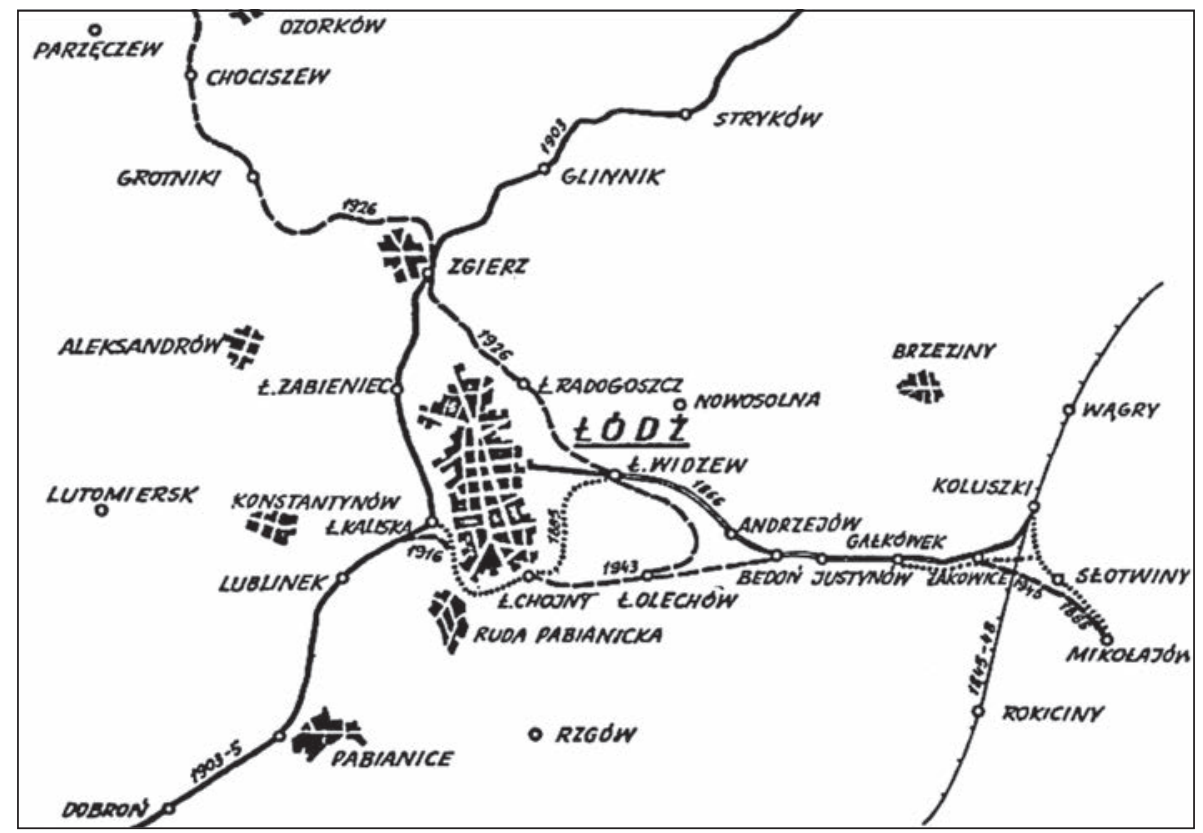

Rysunek 9. Historyczny rozwój kolejowego węzła Łódź

Źródło: Stowarzyszenie Inżynierów i Techników Komunikacji RP Oddział w Łodzi, Studium rozwoju funkcjonalnego łódzkiego węzła kolejowego, za: www.lodz-sitk.org.pl/pliki/forum/2.pdf [z dn. 3.05.2010]

Kolejną ważną inwestycja było włączenie Łodzi w linię biegnąca z Warszawy, przez Sochaczew i Łowicz do Kalisza. Linia przebiegała w ten sposób, iż konieczna stała się budowa drugiego dworca (Łódź 
Kaliska) na przedmieściach miasta. Usprawnienie połączenia z północa przyszło wraz z otworzeniem trasy Łódź Widzew-Zgierz-Kutno. W 1934 r. przebudowie uległ dworzec Łódź Fabryczna, stając się od tej pory dworcem czołowym. Czasy Polski Ludowej przyniosły wymianę torów oraz elektryfikację, a także wydzielenie trasy Gałkówek-Bedoń jako oddzielnej linii kolejowej. Udało się również zmienić układ torów w okolicach stacji Koluszki, tak by pociągi nadjeżdżające z południa nie musiały tracić czasu na zmianę kierunku jazdy, by dotrzeć do Łodzi ${ }^{8}$.

Podsumowując należałoby zauważyć, iż "Łódź, jak wiele miast przemysłowych, nigdy w dziejach nie wytworzyła węzła transportowego odpowiedniego dla miasta, które de facto sprawuje (albo mogło sprawować) funkcje metropolitarne ${ }^{\prime \prime}$. J. Wesołowski wskazuje, iż powodem tak nielogicznego i nieodpowiedniego ukształtowania kolei $\mathrm{w}$ Łodzi było postrzeganie miasta jako „przerośniętej osady fabrycznej”. Budując pierwsze linie, nie wzięto pod uwagę potrzeb przewozowych robotników, skupiając się wyłącznie na transporcie towarów oraz priorytetach sprawujących w danym momencie władzę. Przeszłość ma ogromne znaczenie obecnie, gdy Łódź nie jest już ośrodkiem włókienniczym. Aby miasto mogło się rozwijać i zmieniać, potrzebna jest przebudowa węzła kolejowego, tak by był on postrzegany przez inwestorów jako atut tej lokalizacji oraz by zwiększyć/wspomóc mobilność mieszkańców regionu. Poniżej przedstawiony został wpływ tych zaszłości historycznych na obecną sytuację transportową regionu.

Położenie w centrum kraju sprawia, że przez terytorium regionu łódzkiego przebiegaja główne szlaki kolejowe, również te zaliczane do linii o znaczeniu międzynarodowym. Ze wschodu na zachód biegnie ciąg komunikacyjny Terespol-Warszawa-Kutno-Poznań-Kunowice-E 20, a z północy na południe Trójmiasto-Warszawa-Śląsk-E $65^{10}$. Niestety, trasy te omijaja centralny punkt regionu, czyli samo miasto Łódź, pomimo że jest to ważny węzeł kolejowy na drodze z Wrocławia do Warszawy czy z Poznania do Lublina. O tym, jak marnotrawiony jest potencjał Łodzi najlepiej świadczy fakt, iż jedna z największych stacji towarowych w Polsce, Łódź Olechów, jest wykorzystywana obecnie tylko w 50\% ${ }^{11}$.

8 Tamże.

9 J. Wesołowski, Dylematy restrukturyzacji łódzkiego węzła kolejowego w perspektywie włączenia Łodzi w sieć kolejową dużej prędkości, za: www.toya.net.pl/ pszalk/publ/ pub_3/3Forum_JWesolowski.htm [z dn. 11.10.2012].

${ }^{10}$ A. Nowakowska, Zróżnicowanie rozwoju miast regionu łódzkiego, [w:] A. Jewtuchowicz, A. Suliborski (red.), Struktury i procesy kształtujące łódzki region społeczno-gospodarczy, Wyd. Biblioteka, Łódź 2002, s. 157.

${ }^{11}$ A. Drożyńska i in., Przesłanki rozwoju Łodzi..., s. 113. 
Drogi kolejowe z Łodzi nie prowadzą do tak ważnych polskich miast, jak Rzeszów, Opole czy Gorzów Wielkopolski. Praktycznie niemożliwe jest również dotarcie do nieodległego Konina czy Płocka. W 2005 r. pozbawiono miasto także bezpośredniego połączenia ze Zgorzelcem i Kielcami. Co więcej, Łódź jest bardzo słabo skomunikowana ze stolicami europejskimi. Aglomeracja posiada tylko jeden pociąg międzynarodowy do Pragi („Bohemia”). Brak odpowiedniego połączenia, by dostać się do przejeżdżającego $60 \mathrm{~km}$ od miasta pociągu BerlinWarszawa Express, czy "Jan Kiepura” do Brukseli². Jest to ewenement w skali europejskiej, gdzie połączeń międzynarodowych nie posiadaja tylko miasta wyizolowane ze względu na rozstaw szyn czy położenie geograficzne (góry, na wyspie), jak Ateny czy Dublin. Łódź jednak leży w centrum Polski, na nizinnym terenie i niezrozumiałe jest, iż nie posiada międzynarodowych połączeń kolejowych ${ }^{13}$.

Tabela 3. Stan połączeń Łodzi z sąsiednimi regionami w 2007 r.

\begin{tabular}{|l|c|c|c|}
\hline \multicolumn{1}{|c|}{ Relacja } & $\begin{array}{c}\text { Liczba par } \\
\text { pociagów } \\
\text { na dobę }\end{array}$ & $\begin{array}{c}\text { Czas przejazdu } \\
\text { pociągiem (w h) }\end{array}$ & $\begin{array}{c}\text { Orientacyjny czas } \\
\text { przejazdu samochodem } \\
\text { (centrum-centrum, w h) }\end{array}$ \\
\hline Łódź Fabryczna-Warszawa & 18 & średnio 2,10 & 2,00 \\
\hline Łódź Kaliska-Warszawa & 3 & średnio 2,20 & 2,00 \\
\hline Łódź Fabryczna-Kraków & 1 & 4,20 & 3,00 \\
\hline Łódź Fabryczna-Kraków & 1 & 4,30 & 3,00 \\
\hline Łódź Fabryczna-Katowice & 0 & - & 2,30 \\
\hline Łódź Kaliska-Katowice & 3 & $3,24-4,03$ & 2,30 \\
\hline Łódź Kaliska-Poznań & 2 & $4,30-3,58$ & 2,30 \\
\hline Łódź Kaliska-Wrocław & 3 & $3,56-4,17$ & 3,00 \\
\hline Łódź Kaliska-Bydgoszcz & 5 & $3,46-4,05$ & 3,30 \\
\hline Łódź Kaliska-Gdynia & 4 & $6,49-7,16$ & 6,00 \\
\hline Łódź Kaliska-Lublin/Radom & 1 & $4,54 / 3,23$ & $5,00 / 3,00$ \\
\hline
\end{tabular}

Źródło: Stowarzyszenie Inżynierów i Techników Komunikacji RP Oddział w Łodzi, Studium rozwoju funkcjonalnego łódzkiego węzła kolejowego, za: www.lodz-sitk.org.pl/ pliki/forum/2.pdf [z dn. 3.05.2010].

Region łódzki charakteryzuje się brakiem wewnętrznej spójności pod względem systemu komunikacji kolejowej, zarówno w znaczeniu organizacji połączeń, jak i technicznym. Spośród 20 miast powiatowych aż

12 T. Bużałek, Dlaczego pociągi w Łódzkiem jeżdżą puste?, za: www.toya.net.pl/ pszalk/publ/pub_1/TB_20050107.htm [z dn. 11.10.2012].

${ }^{13}$ T. Bużałek, Kolejowa Łódź - na europejskim dnie, za: www.toya.net.pl/ pszalk/ publ/pub_4/KNL_200611_2.htm [z dn. 11.10.2012]. 
1/3 nie posiada bezpośredniego połączenia z Łodzią. Są to Bełchatów, Pajęczno, Poddębice, Rawa Mazowiecka, Wieluń i Wieruszów. Co więcej, istniejące powiązania są podporządkowane głównie połączeniom z Łodzią, a nie sa wynikowa potrzeb komunikacyjnych miast powiatowych. Na dowód można wskazać, że najwięcej pociągów kursuje pomiędzy stolicą regionu a Sieradzem i Skierniewicami, Łowiczem a Kutnem i Piotrkowem a Radomskiem, czyli miejscowościami, które sa położone na tych szlakach, które łączą Łódź ze stolicami innych województw. Liczba połaczeń oraz istniejące kierunki powoduja, iż południowo-zachodnia część woj. łódzkiego jest marginalizowana, pozostając słabo skomunikowaną z resztą województwa ${ }^{14}$. Jest to istotne, gdyż sieć połączeń, zwłaszcza transportu zbiorowego, tworzy i umacnia więzi pomiędzy ośrodkami danego regionu. Mówi się, że przez nieodpowiednio wykształconą sieć kolejową już dziś Skierniewice są silniej związane z Warszawą niż z Łodzią, Wieluń z Opolem, Tomaszów Mazowiecki z Kielcami czy Radomiem, a powiaty radomszczański i pajęczański ${ }^{15}$ - z Częstochową ${ }^{16}$.

Tabela 4. Stan kolejowych połączeń pasażerskich w regionie łódzkim w 2007 r.

\begin{tabular}{|l|c|l|}
\hline \multicolumn{1}{|c|}{ Odcinek } & $\begin{array}{c}\text { Liczba pociagów } \\
\text { na dobę }\end{array}$ & \multicolumn{1}{c|}{ Uwagi } \\
\hline Łódź Kaliska-Kutno & 9 & $\begin{array}{l}\text { w tym 3 pociągi do Poznania, } \\
\text { 1 do Ostrowa, a tylko 1 } \\
\text { do Zduńskiej Woli }\end{array}$ \\
\hline Łódź Kaliska-Łowicz & 13 & \\
\hline Łódź Kaliska-Koluszki & 2 & $\begin{array}{l}\text { w tym 13 do Skierniewic, } \\
\text { 1 do Drzewicy, a 3 tylko } \\
\text { do Koluszek }\end{array}$ \\
\hline Łódź Fabryczna-Koluszki & 17 & $\begin{array}{l}\text { w tym 1 Łódź Fabryczna- } \\
\text { Skarżysko }\end{array}$ \\
\hline Koluszki-Skierniewice & 13 & \\
\hline Koluszki-Piotrków-Radomsko & 12 & 6 \\
\hline Koluszki-Tomaszów & 2 & \\
\hline Tomaszów-Opoczno & 2 & \\
\hline Zduńska Wola-Chorzew & 4 & \\
\hline Zduńska Wola-Inowrocław & & \\
\hline
\end{tabular}

Źródło: jak do tab. 3.

${ }^{14}$ A. Nowakowska, Zróżnicowanie rozwoju..., s. 157.

15 Taka sytuacja w przypadku tego powiatu nie dziwi, skoro podróż do Łodzi trwa 4 h, ze względu na 2,5-godzinne oczekiwanie na przesiadkę w Zduńskiej Woli (na podstawie: T. Bużałek, Dlaczego pociągi $w$ Łódzkiem...).

16 Tamże. 
Na rok 2007 w Łodzi przewidziano zaledwie 81 połączeń (w tym pociągi sezonowe). Dla porównania, pomiędzy 6:00-7:00 z dworca w Pradze odjeżdżaja 24 pociaggi, z Birmingham - 36, z Helsinek - 62, a z Frankfurtu nad Menem aż 120. Łódź pozbawiona jest także pociagów kwalifikowanych, o podwyższonym standardzie i gwarantujących szybszy przejazd $^{17}$. Tak niespójny wewnętrznie system kolejowy oraz brak odpowiednich połączeń krajowych i międzynarodowych prowadzi do spadku liczby podróżujących tym środkiem transportu. To skutkuje zamykaniem kolejnych połączeń, zaniedbaniami w utrzymywaniu linii i ich poziomu technicznego oraz brakiem chociażby drobnych usprawnień (jak na przykład poprawa jakości przelotu przez stację Łódź Widzew) ${ }^{18}$. Bez podjęcia konkretnych działań łódzki węzeł kolejowy ulegnie całkowitej dewastacji.

W Strategii Rozwoju Województwa Łódzkiego zapisano, iż misja jest „podniesienie atrakcyjności województwa łódzkiego w strukturze regionalnej Polski i Europy jako obszaru sprzyjającego zamieszkaniu ludzi i gospodarce oraz dążenie do budowy wewnętrznej spójności regionu przy zachowaniu różnorodności jego miejsc; wykorzystując atut centralnego położenia regionu..."19. Dalej w tym samym dokumencie można przeczytać, że pożądane przemiany są możliwe do osiągnięcia tylko w przypadku m.in. zwiększenia dostępności województwa poprzez inwestycje w rozwój infrastruktury transportowej. Wśród głównych problemów regionu łódzkiego wskazano zapóźnienia w modernizacji i rozbudowie istniejącego układu komunikacyjnego, brak dobrych powiązań zewnętrznych, jak również słabo zintegrowaną sieć osadniczą. W Strategii sygnalizuje się chęć uczynienia z Łodzi jednego z głównych węzłów systemu osadniczego $\mathrm{w}$ kraju, a w perspektywie połączenie z aglomeracja warszawską i utworzenie jednego z najważniejszych obszarów metropolitalnych Zjednoczonej Europy. Podobny zapis istnieje również w Strategii Mazowsza20. Pierwszym krokiem ku tej wizji jest prowadzona w ostatnich latach przebudowa trasy kolejowej ŁódźWarszawa, przebiegająca w dwóch etapach. Pierwszy obejmował prace związane z modernizacja odcinka Łódź Widzew-Skierniewice i trwał od 2006 do 2008 r. Drugi wiąże się z renowacją trasy Skierniewice-

17 T. Bużałek, Kolejowa Łódź...

${ }^{18} \mathrm{~J}$. Wesołowski, Sieć transportowa w europejskim regionie - koncepcja rozwoju na przykładzie Łodzi, za: http://historia.arch.p.lodz.pl/lodz-kolej.htm [z dn. 11.10.2012].

${ }^{19}$ Strategia Rozwoju Województwa Łódzkiego, [w:] Centrum Naukowo-Techniczne Kolejnictwa, Studium wykonalności budowy linii dużych prędkości Wrocław/PoznańŁódź-Warszawa. Synteza, s. 19-20, za: http://szybkiekoleje.org.pl/UserFiles/File/synteza.pdf [z dn. 11.10.2012].

20 Tamże. 
Warszawa i Łódź Widzew-Łódź Fabryczna ${ }^{21}$. Dzięki przeprowadzonym pracom pociagi pasażerskie będą mogły poruszać się z prędkością 140-160 km/h, a czas podróży do stolicy skróci się z 3h do 65 min²2.

Jednak jest to dopiero początek przebudowy całego łódzkiego węzła kolejowego. Podłożem do dalszych inwestycji będzie przeprowadzenie KDP przez centrum Łodzi. Na bazie nowoczesnych linii kolejowych i rozwiązań infrastrukturalnych, takich jak tunel średnicowy, można będzie dokonać korekty zaniechań popełnianych przez władze od XIX wieku, w następstwie których region łódzki został wyłączony poza główną sieć kolejową Polski.

Jedna z takich inwestycji, istotnych dla regionu łódzkiego, a zaproponowanych właśnie w studium wykonalności KDP, jest zmodernizowanie linii łączącej węzeł Łódź z Centralną Magistralą Kolejową. Trzy główne zadania tego projektu to ${ }^{23}$ :

- modernizacja istniejącej linii na trasie Łódź-Tomaszów Mazowiecki,

- modernizacja i elektryfikacja fragmentu Tomaszów MazowieckiOpoczno,

- budowa odcinka łączącego Stomiankę z Opocznem Południowym, o długości około $3 \mathrm{~km}$.

Dzięki tej inwestycji usprawnione zostanie połączenie Łódź-Kraków. Odległość pomiędzy dworcem Łódź Kaliska a Kraków Główny ulegnie skróceniu do 253,6 km. W znaczącym stopniu wzrosną także prędkości maksymalne na tej trasie (dostosowanie CMK do prędkości $250 \mathrm{~km} / \mathrm{h}$, modernizacja odcinka Kraków-Psary do minimum 160 km/h). Dzięki temu przejazd pociągiem z Łodzi Kaliskiej do Krakowa będzie trwał niecałe $2 \mathrm{~h}$, podczas gdy obecnie czas przejazdu to ponad $5 \mathrm{~h}$. Należy również zauważyć, iż modernizacja odcinka Łódź-Kraków oraz powstanie KDP na trasie Poznań-Łódź oznacza stworzenie nowego, bardzo ważnego połączenia kolejowego: Kraków-Łódź-Poznań-Szczecin ${ }^{24}$.

Plan budowy szybkiej kolei w Polsce zakłada, iż przez Łódź przebiegną najważniejsze szlaki północ-południe oraz wschód-zachód, a miasto stanie się centralnym punktem na mapie kolejowej Polski ${ }^{25}$. Wynikające z tego zalety dla Łodzi i regionu zostały szczegółowo przedstawione w podrozdziale 3.3 .

${ }^{21}$ R. Piech, Łódź Fabryczna dworcem podziemnym?, za: http://inforail.pl/text.php? $\mathrm{id}=14968 \&$ from $=\operatorname{tag}[\mathrm{z}$ dn. 11.10.2012].

22 PKP Polskie Linie Kolejowe S.A., Modernizacja linii Warszawa-Łódź. Etap II, za: www.plk-sa.pl/fileadmin/pdf/INWESTYC]E/Etap_II_Skier_-_W-wa_1.pdf [z dn. 26.04.2010].

${ }^{23}$ A. Massel, Linia dużych prędkości Wrocław/Poznań-Łódź-Warszawa, "Technika Transportu Szynowego" 2005, nr 12 (grudzień), s. 39.

24 Tamże.

25 J. Raczyński, Rządowy program budowy linii dużych prędkości w Polsce, "Technika Transportu Szynowego" 2008, nr 9 (wrzesień), s. 20. 


\subsection{Techniczne aspekty budowy tunelu średnicowego i dworca kódź Fabryczna}

Pomysł budowy tunelu średnicowego w Łodzi pojawił się już w 1866 r. w okresie powstawania kolei, na co wskazuje ówczesny przelotowy charakter dworca Łódź Fabryczna (brano wówczas pod uwagę korytarz na- lub nadziemny). Po 1945 r. rozważano budowę tunelu w poprzek gęsto zabudowanego śródmieścia w celu połączenia z dworcem Łódź Kaliska ${ }^{26}$. W czasach Polski Ludowej pojawiły się dwie opcje przebiegu linii średnicowej. Pierwszy wariant zakładał budowę tunelu z obecnej lokalizacji dworca Łódź Fabryczna do dworca Łódź Kaliska i linii w kierunku Zgierza. Wariant drugi uwzględniał linię średnicową biegnąca od dworca Łódź Widzew do dworca Łódź Kaliska na wysokości ulicy Drewnowskiej. Tam miał powstać nowy węzeł komunikacyjny, co tłumaczyłoby obecna peryferyjną lokalizację autobusowego Dworca Północnego ${ }^{27}$. Obecnie idea średnicy powróciła wraz z projektem budowy szybkiej kolei w Polsce.

Zostało już wspomniane, że za najkorzystniejszy wariant przebiegu superekspresu w Polsce uznano ten zakładajacy przeprowadzenie linii przez samo centrum Łodzi, przy pomocy tunelu średnicowego łączącego dworce Łódź Fabryczna i Łódź Kaliska. W tym przypadku dworzec Łódź Fabryczna, całkowicie przebudowany i przeniesiony pod ziemię, stanie się głównym dworcem w mieście, obsługującym wszystkie "ciężkie pociągi" przejeżdżające przez Łódź. Wariant 1 opcja II zakłada przeprowadzenie relacji Warszawa-Wrocław oraz Warszawa-Poznań nowo wybudowaną linią dużych prędkości, przebiegająca do okolic wsi Niesułków w korytarzu autostrady A2, dalej przejście łukiem na południe od korytarza autostrady $\mathrm{A} 1^{28}$, po czym przeciwnym łukiem w celu

${ }^{26}$ J. Wesołowski, Ukształtowanie kolejowego węzła łódzkiego i możliwości jego włączenia w system kolei dużych prędkości, "Technika Transportu Szynowego" 2005, nr 12 (grudzień), s. 44.

${ }^{27}$ R. Piech, Historia węzła Łódź...

${ }^{28}$ Trasy te wpisuja się $w$ europejską sieć komunikacyjną. Większość $z$ aktualnie istniejących odcinków powstawała w latach 2007-2011, za kadencji ówczesnego ministra infrastruktury C. Grabarczyka, m.in. odcinek autostrady A2 Świecko-Nowy Tomyśl (oficjalnie oddany do użytku 1 grudnia 2011 r.) - zob. http://autostrada-a2.pl/pl/a2-doswiecka/aktualnosci/153/autostrada-a2-do-swiecka-juz-otwarta [z dn. 25.02.2013] czy trzy odcinki autostrady A1 biegnące z Rusocina (okolice Gdańska) do Czerniewic (koło Torunia) oddane do użytku odpowiednio: 22 grudnia 2007 r. (25 km), 17 października 2008 r. $(65 \mathrm{~km}), 14$ października 2011 r. $(62 \mathrm{~km})$ - zob. www.autostradaa1.pl/index. php?page $=$ home\&fpage $=$ afakty\&lang $=$ pl,$\quad$ www.gddkia.gov.pl/pl/a/8085/a1-nowe-marzy-torun, www.gddkia.gov.pl/pl/a/9987/autostrada-a1-nowe-marzy---torun---otwarta [z dn. 25.02.2013]. 
włączenia się w okolicach dworca Łódź Widzew w pas Kolei Fabrycznej. Następnie szybkie pociagi będa kursować w istniejącym korytarzu kolejowym do głównego dworca Łódź Fabryczna, a dalej tunelem na druga stronę śródmieścia. Linia średnicowa będzie wyprowadzona między przedmieściami Złotna i Teofilowa do trasy wysokich prędkości w okolicach Lutomierska29. Przebieg linii KDP przez województwo łódzkie pokazuje rys. 10.

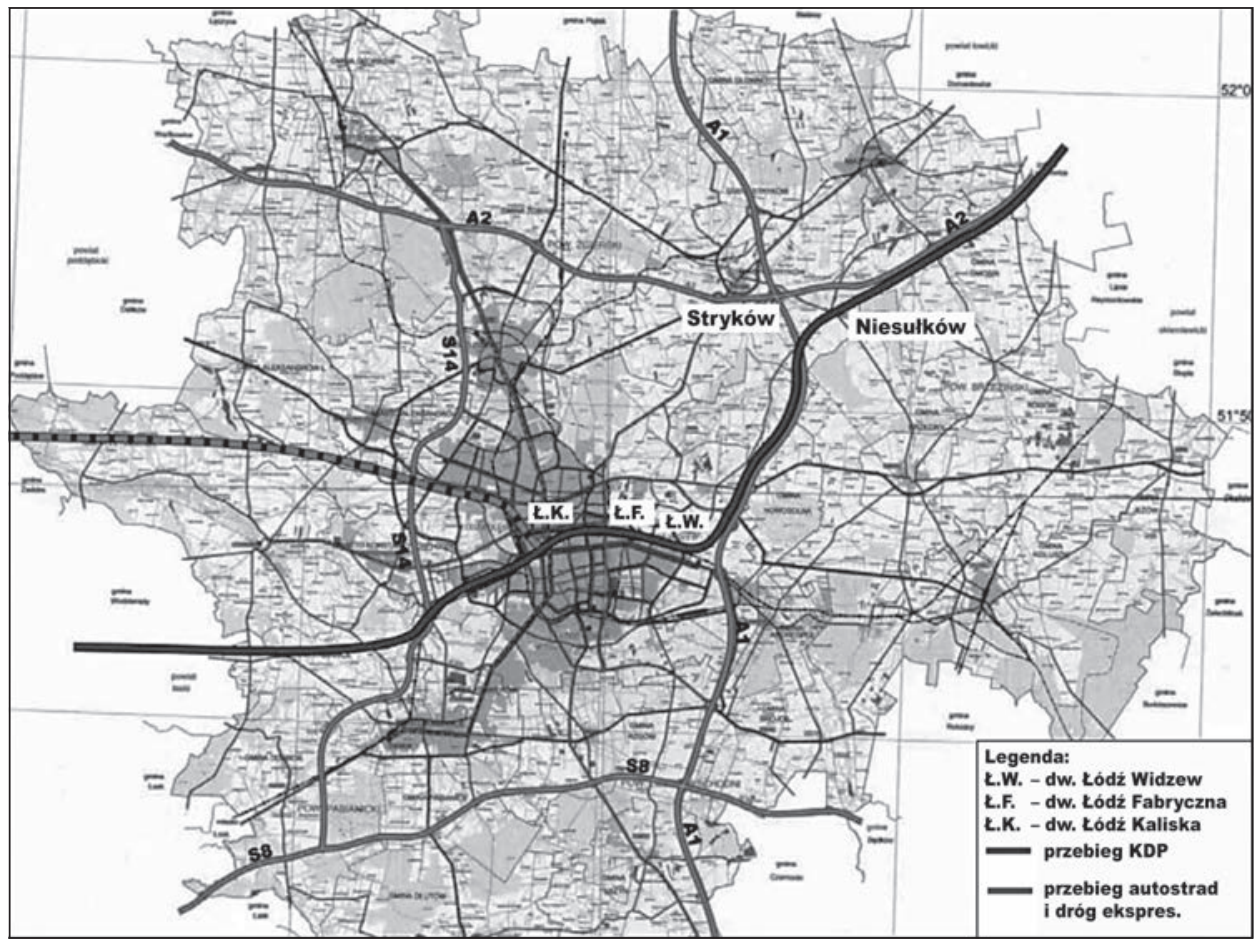

Rysunek 10. Przebieg linii kolei dużych prędkości przez województwo łódzkie

Źródło: A. Giedryś, Możliwości przebiegu linii dużej prędkości przez Łódź, s. 6, za: www.lodz-sitk.org.pl/pliki/forum/3.pdf [z dn. 30.04.2010]

Już w 2007 r. miasto Łódź podpisało umowę z PKP w sprawie wymiany i zagospodarowania terenu przeznaczonego pod przyszły dworzec oraz tunel, tym samym możliwe było rozpoczęcie procesu inwestycyjnego ${ }^{30}$. Pierwszym etapem prac, które prowadzone sa od października 2009 r., jest przystosowanie dworca Łódź Widzew do przejęcia podróżnych z dworca Łódź Fabryczna (rozbudowanie pawilonu dworcowego, przy-

${ }^{29}$ Centrum Naukowo-Techniczne Kolejnictwa, Studium wykonalności..., s. 32.

30 J. Raczyński, Rządowy program budowy..., s. 20. 
gotowanie dwóch parkingów na 150 miejsc każdy, powstanie postoju taksówek oraz pętli autobusowej ${ }^{31}$ ).

Stacja Łódź Fabryczna została zamknięta na przełomie I i II kwartału 2010 r. i rozpoczęła się jej przebudowa, tak by już w 2013 r. rozpoczęła na nowo obsługę pasażerów. Modernizacji będzie również poddany odcinek kolei Łódź Widzew-Łódź Fabryczna. Prace, polegające na stopniowym chowaniu torów pod ziemię (metodą otwartego wykopu) rozpoczęły się już w 2010 r. ${ }^{32}$ Do końca 2011 r. zostało również ukończone studium wykonalności dla tunelu średnicowego, które dało odpowiedź na pytania, jak ma przebiegać tunel pod miastem oraz w jaki sposób należy połączyć go z istniejącym układem komunikacyjnym. Przeprowadzone zostały również badania archeologiczne, geologiczne, a także badania dotyczące wpływu budowy tunelu na środowisko naturalne ${ }^{33}$. Miasto Łódź, PKP Polskie Linie Kolejowe S.A. oraz Samorząd Województwa Łódzkiego, w ramach trójstronnego porozumienia zawartego 26 września 2009 r., zadeklarowały kwotę po $1,8 \mathrm{mln}$ zł na opracowanie studium ${ }^{34}$. Złożony został również wniosek aplikacyjny o dofinansowanie tego projektu z funduszy unijnych. Wykonanie samego tunelu rozpocznie się po zakończeniu prac związanych z dworcem Łódź Fabryczna, wraz z początkiem budowy "trasy Y", czyli w 2014 r. Podobne budowy trwaja około 2 lat, więc zakłada się, że w 2016 r. tunel będzie gotowy do obsługi pociagóó. Jeżeli prace nad szybką koleja będa przebiegać równie sprawnie, według prezesa PKP Polskie Linie Kolejowe S.A., Z. Szafrańskiego, już w 2018 r. superekspresy przejada pod Łodzią. Jeśli budowa tunelu się opóźni ze względu na geologiczne ukształtowanie terenu, KDP ze stacji Łódź Widzew pojedzie przez Chojny ${ }^{35}$.

W planach dotyczących szybkiej kolei w Polsce zakłada się, iż zakres prac związanych z przebudową węzła łódzkiego obejmie ${ }^{36}$ :

a) przygotowanie wszelkiej dokumentacji oraz pozwoleń niezbędnych do wykonania i odbioru robót,

${ }^{31}$ http://inforail.pl/text.php?id=31549 [z dn. 11.10.2012].

32 P. Wasiak, Pociągi przejadą pod miastem ponad $300 \mathrm{~km} / \mathrm{h}$, za: http://miasta.gazeta.pl/lodz/1,35153,7081258,Pociagi_przejada_pod_miastem_ponad_300_km_h.html [z dn. 11.10.2012].

${ }^{33}$ M. Kudlicka, Kolej XXI wieku rozpoczyna swój bieg w Łodzi!, za: www.uml.lodz.pl/ index.php?str $=1732 \& i d=17249$ [ $z$ dn. 30.11.2011].

${ }^{34}$ www.ec1kolejowy.pl/pl/aktualnoci/290-operacja-tunel-pod-odzi-akt-pierwszy. html [z dn. 11.10.2012].

${ }^{35}$ www.ec1kolejowy.pl/pl/publications/2009-listopad-grudzie/181-od-bdziecentralna.html [z dn. 11.10.2012].

${ }^{36}$ http://inforail.pl/text.php?id=31549 [z dn. 11.10.2012]. 
b) budowę tunelu średnicowego pod centrum miasta, dwuprzestrzennego z linią czterotorowa, zdolna do obsługi nie tylko KDP, ale również pociągów regionalnych, aglomeracyjnych i dalekobieżnych (na poziomie od 0 do $-16,5)$,

c) przebudowę stacji Łódź Fabryczna na dworzec podziemny, z czterema peronami do obsługi ośmiu torów (główki szyny będą się znajdować na poziomie od -8 do $-16,5)$,

d) budowę pawilonu dworcowego pod ziemia, wraz z wyposażeniem (na poziomie od 0 do -18 ),

e) wykonanie po północnej stronie nowego dworca kolejowego trzykondygnacyjnych parkingów podziemnych (na poziomie od -8 do -17),

f) budowę po północnej stronie nowego dworca kolejowego podziemnych przystanków autobusów (na poziomie od 0 do -8),

g) budowę i zabezpieczenie wykopu znajdującego się po południowej stronie nowego dworca kolejowego,

h) przebudowę dróg dojazdowych do dworca od strony północnej, śladem dzisiejszych ulic Składowej i Węglowej, między ulicą Kilińskiego oraz planowanym przedłużeniem ulicy Uniwersyteckiej (na poziomie 0),

i) usunięcie wszelkiej infrastruktury technicznej, która mogłaby przeszkadzać w inwestycji oraz wykonanie niezbędnej nowej do funkcjonowania multimodalnego węzła komunikacyjnego,

j) budowę linii tramwajowej biegnącej ulicami Składową i Węglowa, po północnej stronie dworca,

k) wykonanie przystanków tramwajowych i autobusowych na ulicy Węglowej,

I) przygotowanie zachodniego i wschodniego przedpola nowego dworca kolejowego oraz przystanków autobusów, w celu włączenia ich do układu komunikacyjnego miasta.

W prezentacji przygotowanej przez Zarząd Dróg i Transportu w Łodzi ${ }^{37}$, tunel miałby przebiegać od dworca Łódź Fabryczna, pod skrzyżowaniem ulic Kilińskiego i Składowa-Traugutta, dalej pomiędzy ulicami 6 Sierpnia oraz Zielona (równolegle do nich), do skrzyżowania 6 Sierpnia-Lipowa. Następnie łukiem w kierunku południowym pomiędzy ulicami 6 Sierpnia i Struga, „przecinając” aleję Włókniarzy, dworzec Łódź Kaliska i aleję Mickiewicza. Odgałęzienie linii kolei regionalnej o długości prawie 4,5 km ma się rozpoczynać na wysokości ulicy Żeligowskiego i prowadzić na północ. Pociągi będą stopniowo zjeżdżać

${ }^{37}$ A. Giedryś, Możliwości przebiegu linii dużej prędkości przez Łódź, Łódź 2005, s. 7-14. 
do tunelu i z niego wyjeżdżać. Swój początek tunel będzie miał w okolicach ulicy Kopcińskiego, a "wynurzenie się" z niego rozpocznie się za placem Hallera.

Przez obszar administracyjny Łodzi będzie przebiegała linia kolei dużych prędkości o długości ponad $24 \mathrm{~km}$. Powstaną również nowe lub zostana zmodernizowane stare linie służące do obsługi pociągów regionalnych o łącznej długości $18,32 \mathrm{~km}$. W tunelu przebiegać będzie prawie 19\% długości tych linii (tunel będzie miał 4,5 km), w krytym wykopie około $10 \%$, a w wypłycaniu 18,5\%. Projektowana prędkość pociągów na terenie łódzkiego węzła kolejowego ma wynosić 100-120 km/h dla KDP oraz $100 \mathrm{~km} / \mathrm{h}$ dla kolei konwencjonalnej. Zakłada się, iż budowa linii dla superekspresów będzie kosztowała około $462 \mathrm{mln}$ euro, a linii regionalnej od stacji Janów do dworca głównego - około $141 \mathrm{mln}$ euro ${ }^{38}$. W związku z wykorzystywaniem tunelu przez kolej aglomeracyjną przewiduje się utworzenie dwóch przystanków: jeden na wysokości skrzyżowania ulicy Zielonej i Zachodniej, a drugi pod placem Hallera ${ }^{39}$.

Tunel będzie budowany metoda "górnicza", tzn. tak jak metro40. Do drążenia może zostać wykorzystana mechaniczna tarcza tunelowa, tzw. TBM - takiej maszyny używają m.in. konstruktorzy City Tunnel Leipzig, który często stawiany jest Łodzi za wzór wykonania projektu tego typu ${ }^{41}$. W średnicy będa przebiegały cztery torowiska: dwa dla KDP oraz dwa dla kolei konwencjonalnej ${ }^{42}$, co wskazuje, iż w przyszłości spodziewane są duże potoki pasażerów. Ważne jest, że już w fazie planowania przedsięwzięcia zakłada się wzmożony ruch, ponieważ dzięki temu uniknie się sytuacji, w której Łódź stałaby się wąskim gardłem polskiej linii KDP. Wprowadzając szybką kolej do samego centrum miasta, Łódź bierze na siebie za to odpowiedzialność. Musi być zapewniona odpowiednia przepustowość tunelu, tak aby superekspresy mogły rozwijać maksymalne prędkości, a jednocześnie miasto czerpało korzyści z wykorzystania tunelu dla potrzeb przewozowych międzyregionalnych oraz aglomeracyjnych.

Cały węzeł Łódź Fabryczna zostanie przeniesiony poniżej poziomu miasta. Tory i perony będą się znajdowały 16,5 metra pod ziemia, a 10,5 metra ponad nimi będzie zorganizowana podziemna sieć ulic i część

38 Tamże, s. 15 i 21-22.

39 M. Kudlicka, Kolej XXI wieku...

${ }^{40}$ www.ec1lodz.pl/aktualnosci.php?news_id $=42$ [z dn. 1.03.2010].

${ }^{41}$ www.nbi.com.pl/city-tunnel-leipzig-2 [z dn. 11.10.2012].

42 PAP, Ponad 4 mld zł ma kosztować przebudowa dworca Łódź Fabryczna, za: http:// gospodarka.gazeta.pl/gospodarka/1,33205,6105542,Ponad_4_mld_zl_ma_kosztowac_ przebudowa_dworca_Lodz.html [z dn. 30.10.2009]. 
dworca dla autobusów ${ }^{43}$. Nowy dworzec stanie się głównym węzłem multimodalnym w centralnej Polsce, obsługującym KDP, kolej międzyregionalną i aglomeracyjna, autobusy PKS oraz międzynarodowe, komunikację miejską, a także parkingi dla samochodów i postoje taksówek ${ }^{44}$.

Zakres prac w ramach przebudowy dworca obejmuje ${ }^{45}$ :

- wykonanie wykopu na głębokość 16,5 metra,

- wzmocnienie ścian wykopu,

- przygotowanie systemu odwadniania wykopu,

- budowę dworca podziemnego z 3 peronami o długości 4 metrów.

Struktura nowego dworca Łódź Fabryczna:

- Poziom 3: program biurowo-hotelowy,

- Poziom 2: program usługowo-rozrywkowy,

- Poziom 1: program usługowo-handlowy,

- Poziom 0: dworzec PKP, PKS, usługi, dojazdy,

- Poziom -1: dworzec kolejowy, usługi, parkingi,

- Poziom -2: tory i perony.

Na zrewitalizowanym terenie nad dworcem oraz $w$ miejscu dawnej elektrociepłowni EC-1 (90 ha terenu) ma powstać Nowe Centrum Łodzi z ośrodkami kulturalnymi, festiwalowo-kongresowymi oraz usługowymi. Wybudowane zostana również hotele, biurowce, apartamenty mieszkalne i galerie handlowe ${ }^{46}$.

W zachodniej części tego terenu maja znajdować się obiekty związane z transportem, kulturą i usługami komercyjnymi. Obszar wschodni będzie zarezerwowany dla usług komercyjnych, mieszkalnictwa oraz zieleni miejskiej. Trzecim wyodrębnianym obszarem jest tzw. „przestrzeń publiczna", czyli ulice i aleje, parki oraz główny punkt Nowego Centrum - Rynek Kobro47 (nazwa na cześć wybitnej rzeźbiarki okresu dwudziestolecia międzywojennego - Katarzyny Kobro ${ }^{48}$ ). Budynek Dworca Fabrycznego zostanie odrestaurowany i będzie pełnił funkcje artystyczne, podobnie jak w Brukseli, gdzie zachowano stary pawilon dworcowy obok nowoczesnego, ukrytego pod ziemia ${ }^{49}$.

Przebudowa dworca oraz zagospodarowanie terenu wokół niego ma pochłonąć ponad $4 \mathrm{mld} z ł^{50}$. Wraz z modernizacją infrastruktu-

\footnotetext{
${ }^{43}$ http://inforail.pl/text. php?id=27639\&from $=\operatorname{tag}$ [z dn. 11.10.2012].

44 PAP, Ponad 4 mld zł ma kosztować...

${ }^{45}$ http://inforail.pl/text.php?id=27639\&from $=\operatorname{tag}[z \mathrm{dn} .11 .10 .2012]$.

46 PAP, Ponad 4 mld zł ma kosztować...

${ }^{47}$ Regionalne Forum Transportowe, Stacja Łódź. Łódź Fabryczna, za: www.lodz-sitk. org.pl/pliki/forum/4.pdf [z dn. 3.03.2010].

48 http://kobro.art.pl [z dn. 11.10.2012].

${ }^{49}$ http://uml.lodz.pl/index.php?str=1200\&id=17533 [z dn. 30.11.2011].

50 PAP, Ponad 4 mld zł ma kosztować...
} 
ry liniowej łączny koszt wyniesie około $8 \mathrm{mld}$ zł (około $986 \mathrm{mln}$ euro przeznaczone jest na budowę linii obsługujących KDP oraz kolej regionalna ${ }^{51}$ ). Pomimo iż ten wariant przebiegu szybkiej kolei przez Polskę jest droższy od pozostałych, eliminuje on niedogodności związane z obecnym kształtem łódzkiego węzła kolejowego. Co więcej, Łódź w końcu przestanie być wąskim gardłem na kolejowej mapie Polski i będzie mogła pełnić rolę głównego punktu tranzytowego - miejsca w którym przecinaja się najważniejsze szlaki kolejowe północ-południe oraz wschód-zachód. C. Grabarczyk uważał, że w połączeniu z budowaną infrastruktura drogową zapewni to województwu łódzkiemu doskonałe skomunikowanie z pozostałymi regionami Polski. Dzięki inwestycji w nowoczesne zagospodarowanie przestrzeni, zaniedbane okolice dworca Łódź Fabryczna zmienią się w miejsce tętniące życiem. Nowe Centrum, położone dosłownie nad dworcem, przyciągnie turystów oraz inwestorów, a wraz z nimi - ich pieniądze oraz szansę dla miasta na rozwój społeczno-gospodarczy i nowe miejsca pracy.

\subsection{Znaczenie tunelu w Łodzi dla sieci KDP oraz całej aglomeracji}

Według specjalistów, dobra dostępność komunikacyjna jest uznawana przez zagranicznych inwestorów za jeden z najistotniejszych czynników lokalizacji działalności gospodarczej. Dostępność komunikacyjna obejmuje ilość oraz jakość szlaków drogowych, jak i kolejowych, a także kierunki oraz natężenie połączeń pasażerskich czy stopień teleinformatyzacjis2.

Oczywisty wydaje się również wpływ rozwoju infrastruktury transportowej na rozwój regionu czy kraju, a przede wszystkim na pobudzenie działalności gospodarczej. A. Grabska stawia tezę, iż występuje sprzężenie zwrotne: rozwój państwa wpływa na stan infrastruktury, a infrastruktura wpływa na łatwość i efektywność korzystania z zasobów, których wykorzystanie prowadzi do wzrostu gospodarczego kraju53. W przypadku Łodzi nieodpowiedni i niedostosowany do potrzeb

${ }^{51}$ A. Giedryś, Możliwości przebiegu linii dużej prędkości..., s. 23.

${ }^{52}$ C. Brzeziński, Problemy komunikacji i perspektywy jej rozwoju w województwie łódzkim, [w:] A. Jewtuchowicz (red.), Strategiczne problemy rozwoju regionów w procesie integracji europejskiej, Wyd. Uniwersytetu Łódzkiego, Łódź 2001.

${ }^{53}$ A. Grabska, Infrastruktura jako czynnik konkurencyjności, [w:] A. Chmielak (red.), Wybrane problemy kształtowania infrastruktury rozwoju zrównoważonego, Wyd. Politechniki Białostockiej, Białystok 2001, s. 55. 
układ dróg i kolei, jak wskazuje W. Grzywacz, mógł wpłynać hamująco na dynamikę rozwoju społecznego i wzrostu gospodarczego ${ }^{54}$. Włączenie miasta w europejską sieć szybkiej kolei znacznie poprawi sytuację i może mieć stymulujący wpływ na gospodarkę regionu. Korzystne warunki transportowe zapewnią możliwość integracji z innymi krajami oraz regionami, zapewnią również większą spójność samego województwa łódzkiego.

Aby $\mathrm{w}$ pełni wykorzystać atuty swojego położenia w centrum Polski, na przecięciu najważniejszych szlaków kolejowych (szybkiej kolei), Łódź powinna nastawić się na obsługę głównie ruchu tranzytowego. Nie ma w tym nic złego, gdyż dzięki tej funkcji Łódź zapewni sobie wygodna, ze znaczną częstotliwością obsługę miasta oraz większych ośrodków całego regionu. Głównym kierunkiem ruchu tranzytowego byłby odcinek Warszawa-Wrocław. Na niego nakładałaby się trasa Łódź-Warszawa, która aktualnie generuje największe potoki pasażerów. Wzmożenie ruchu może nastapić w przypadku połączenia Wielkopolska-Śląsk, które obecnie, ze względu na bardzo długi czas podróży, jest słabo obłożone ${ }^{55}$. Co więcej, kierunek ten stwarza możliwość ponownego aktywowania międzynarodowych połączeń przez Wrocław do Pragi, Lipska i Drezna ${ }^{56}$. Drugim kierunkiem tranzytu byłby Warszawa-Poznań, dzięki któremu w przyszłości z Łodzi będzie można dojechać koleja do Berlina, a może i do Moskwy. Trzecim kierunkiem jest trasa Katowice-Gdańsk. Zbudowanie połączenia Łódź-CMK, która w tym momencie omija Polskę Środkowa, pozwoli na podróż szybkim pociągiem z Katowic, przez Kraków, Łódź, Poznań do Szczecina w rekordowym czasie 5 godzin (obecnie 8,30) ) $^{57}$.

Analizy wykazuja, iż Dworzec Fabryczny obsługujący dotychczas 11 tys. pasażerów dziennie, w 2040 r. będzie przyjmować 170 tys. podróżnych na dobę ${ }^{58}$. Co więcej, przewozy w 2030 r. tylko na głównych trasach, czyli Łódź-Warszawa, Łódź-Wrocław oraz Łódź-Poznań wzrosną około 2,5-krotnie $w$ porównaniu z rokiem 2010. Uwzględniając w tej prognozie ruch przeniesiony z dróg, w 2020 r. dzienne przewozy koleja w obu kierunkach będa generowały następujące strumienie pasażerów: do/z Warszawy 34457 pasażerów, do/z Wrocławia 6685, a do/z Poznania 8787. Sytuacja taka nie dziwi, gdyż "trasa Y" połączy największe aglomeracje w Polsce - wraz z Kaliszem i Ostrowem będzie

${ }^{54}$ W. Grzywacz, Infrastruktura transportu, Wyd. Komunikacji i Łączności, Warszawa 1982, s. 172.

55 J. Wesołowski, Ukształtowanie kolejowego węzła łódzkiego..., s. 46.

56 J. Raczyński, Rządowy program budowy..., s. 23.

57 J. Wesołowski, Sieć transportowa w europejskim regionie...

${ }^{58}$ www.ec1lodz.pl/aktualnosci.php?news_id=42 [z dn. 1.03.2010]. 
to $5 \mathrm{mln}$ ludności, charakteryzującej się dużą mobilnością i przedsiębiorczością. Bezpośrednio włączone w sieć KDP zostanie 10 mln ludności, a gdy uda się inkorporować w sieć również CMK - następne $5 \mathrm{mln}^{59}$. Analizy wskazuja, iż dzięki sprawnej kolei wzrośnie również mobilność samych łodzian. W latach 2020-2030 maja odbywać po 15 podróży rocznie, co daje 32 tys. podróży na dobę. Zakłada się, iż tyle samo osób odwiedzi Łódź, gdyż dzięki uczestnictwu w KDP miasto zyska na atrakcyjności $w$ oczach turystów ${ }^{60}$. Dla miasta to szansa, aby "zatrzymać" te ogromne potoki ludzi: zapewnić im nocleg, rozrywki, nakarmić, ubrać... - dostarczyć wszelkich dóbr i usług, których będą potrzebować.

Zastanawiając się nad tym, czemu nagle przewozy pasażerskie koleja miałyby wzrosnąc $w$ tak znacznym stopniu za sprawą superekspresów, odpowiedź można uzyskać w wypowiedzi prezesa zarządu PKP PLK S.A., Z. Szafrańskiego: „Wiele osób twierdzi, że przy takich rozmiarach, jakie ma Polska, a sa to średnie wielkości $600-700 \mathrm{~km}$ rozciągłości ze wschodu na zachód i z północy na południe, wystarczą pociągi jeżdżące z prędkością 160, a nawet $120 \mathrm{~km} / \mathrm{h}$. W mojej ocenie nie wystarcza, ponieważ podróże biznesowe powinny się zamykać w czasie od 2,5 do 3 godzin. Jeśli skrócimy czas przejazdu z Warszawy do Wrocławia o 20 minut, dużo podróżnych nam od tego nie przybędzie. Jeżeli natomiast zrobimy to w sposób radykalny i z 5 godzin zejdziemy na niecałych 2, to się okaże, że pasażerowie z Jeleniej Góry, Zielonej Góry, Leszna, jadąc do Wrocławia i dalej do Warszawy, będą mieli czas podróży na tyle atrakcyjny, że zdecydują się na podróż pociągiem. Skrócenie czasu generuje dodatkowe potoki podróżnych. Doświadczenia kolei zachodniej, w szczególności hiszpańskiej pokazuja, że szybka kolej podnosi liczbę pasażerów o ok. 20-30\%"61. Do niedawna $\mathrm{w}$ regionie łódzkim dominowało przekonanie, iż najważniejsze jest włączenie miasta w sieć autostrad i dróg szybkiego ruchu. Należy jednak podkreślić, iż w krajach zachodnich biznesmeni i politycy nie odbywaja podróży służbowych samochodem, ale samolotem lub szybka koleja. To szybka kolej oznacza dziś prestiż i luksus, nowoczesność i bogactwo. Dla Łodzi to nobilitacja do grupy najważniejszych ośrodków w Europie, w których zatrzymują się superekspresy oraz związane $z$ tym korzyści materialne i niematerialne.

59 J. Raczyński, Rządowy program budowy..., s. 21.

60 Stowarzyszenie Inżynierów i Techników Komunikacji RP Oddział w Łodzi, Studium rozwoju funkcjonalnego łódzkiego węzła kolejowego, za: www.lodz-sitk.org.pl/pliki/forum/2.pdf [z dn. 3.05.2010].

${ }^{61}$ www.ec1kolejowy.pl/pl/publications/2009-listopad-grudzie/181-od-bdziecentralna.html [z dn. 11.10.2012]. 
W większości miast europejskich, w których istnieje tunel średnicowy, służy on do rozprowadzenia ruchu aglomeracyjnego i regionalnego po centrum. Biorąc pod uwagę, iż Łódź jest jedynym miastem tej wielkości w Europie, w którym nie funkcjonuje metro czy Szybka Kolej Miejska, owa inwestycja może stać się przełomowa w tym zakresie. Łódź, która wraz z Pabianicami, Ozorkowem, Zgierzem i innymi miastami tworzy 1,1-milionowa aglomerację, "utonie" w korkach, hałasie i spalinach, jeśli nie będzie posiadała sprawnego transportu szynowego. Jak wskazuja analizy, przekroczona została przepustowość dróg kołowych w kierunku: Zgierza (średni dobowy ruch w 2000 r. wynosił 14 966), Pabianic (15 313 pojazdów w ciaggu doby) czy Piotrkowa Trybunalskiego, gdzie natężenie ruchu w ciągu doby wynosi 25806 pojazdów. Brak Szybkiej Kolei Miejskiej prowadzi do pogarszania się sytuacji mieszkańców miasta i migracji na obrzeża oraz do innych aglomeracji, gdzie nie dopuszczono do takich zaniedbań. Rozwiązanie problemu nadejdzie wraz z budową tunelu średnicowego. Posiadając odpowiednią infrastrukturę liniowa, jedyną inwestycją będzie zakup odpowiednich pojazdów, na przykład typu EZT, które są obecnie wykorzystywane przez PKP62.

Dzięki kolei miejskiej mieszkańcy peryferyjnych dzielnic, takich jak Widzew, Janów, Żabieniec czy Retkinia, uzyskaliby szybki i wygodny dostęp do centrum miasta. W przyszłości, w miarę rozwoju projektu, można zorganizować dojazdy do centrum w systemie Park \& Ride, tzn. na obrzeżach śródmieścia przygotować parkingi, przy których spieszący do centrum przesiadaliby się z własnych środków transportu do komunikacji miejskiej.

Takie połączenie pociaggu, kursującego po szynach tramwajowych, umożliwiłoby połączenie z Łodzia nawet dalej położonych miejscowości, jak Pabianice, Kutno, Piotrków Trybunalski, Bełchatów czy Tomaszów Mazowiecki63. Prognozuje się, iż dziennie z takiej kolei korzystałoby nawet $20 \mathrm{mln}$ pasażerów (założenie: 320 pociągów dziennie, w każdym po 170 podróżujących) już w pierwszym roku uruchomienia, a w kolejnych nawet $30 \mathrm{mln}$. SKM ${ }^{64}$ nie stanowiłaby bezpośredniej konkurencji dla tramwajów, gdyż ich trasy by się nie dublowały. Ograniczona natomiast zostałaby liczba autobusów miejskich, których zadaniem byłoby dowożenie pasażerów do stacji kolei. Problemem, który może wystąpić w przypadku tej inwestycji,

${ }^{62}$ A. Fularz, Kolej miejska w Łodzi - ratunek dla aglomeracji, za: www.obywatel.org. $\mathrm{pl} /$ index.php? module $=$ subjects\&func $=$ viewpage \&pageid $=594[\mathrm{z} \mathrm{dn} .31 .10 .2009]$.

63 J. Wesołowski, Ukształtowanie kolejowego węzła łódzkiego..., s. 47.

${ }^{64}$ SKM - Szybka Kolej Miejska. 
są nieodpowiednie warunki przestrzenne na styku kolei i struktury miasta. Za przykład podaje się głównie stację Łódź Kaliska, której przydatność do obsługi miasta jest niska (w pobliżu nie znajdują się ani duże osiedla, ani zakłady pracy). Wyjściem z sytuacji może być dobudowanie krótkich odgałęzień, na przykład do centrum osiedla Widzew czy Retkinia65.

Należy również zauważyć, iż dzięki połączeniu łódzkich dworców linią średnicową możliwe będzie stworzenie dogodnego połączenia kolejowego z Portem Lotniczym im. W. Reymonta. Terminal lotniczy znajduje się w odległości około $1 \mathrm{~km}$ od linii Łódź-Ostrów Wielkopolski (kolej kaliska) - dzięki odpowiedniej przebudowie port będzie mógł być obsługiwany pociagami z Warszawy, a tym samym zostać włączony w multimodalny system komunikacyjny Polski, opierający się na autostradach i drogach szybkiego ruchu, lotniskach oraz szybkiej kolei66.

Jak już zostało wspomniane, ekspertyza dotycząca potencjału i przyszłości polskich metropolii wykazała, iż Łódź cechuje się najmniejszym potencjałem rozwojowym ze względu na regres ludnościowy i stagnację gospodarcza. Niektórzy specjaliści twierdza, iż jedyną szansą dla miasta jest bliższe związanie się ze stolica. Istnienie szybkiej kolei pomiędzy tymi miastami na pewno pozytywnie wpłynie na zacieśnienie więzi między przemysłową Łodzią a Warszawą. Oba miasta moga czerpać z tego wymierne korzyści, chociażby w postaci napływu bezpośrednich inwestycji zagranicznych. Wskazuje się również, iż układ bipolarny może prowadzić do synergii na płaszczyźnie generowania innowacji, świadczenia usług, prowadzenia działalności produkcyjnej, badawczo-naukowej, handlowej czy logistycznej na poziomie międzynarodowym ${ }^{67}$.

Trzeba sobie uzmysłowić, iż impuls, jakim był plan budowy kolei, powoduje szereg kolejnych inwestycji i zmian, zwłaszcza w przypadku Łodzi. Budowa tunelu średnicowego w celu przeprowadzenia KDP pod miastem oznacza m.in. możliwość wykorzystania go do uruchomienia Szybkiej Kolei Miejskiej. Stwarza również konieczność przeniesienia Dworca Fabrycznego pod ziemię. To z kolei staje się przyczynkiem do całkowitej rewitalizacji śródmieścia, szeroko pojętej przebudowy tego terenu. Zaniedbane, upadające kamienice, ruiny fabryk zostana zburzone, a na ich miejscu pojawi się modernistyczne Centrum Łodzi, które przyciągnie turystów i zachęci inwestorów. Co więcej, Nowe Centrum być może powstrzyma proces decentralizacji i upadku

${ }^{65}$ A. Fularz, Kolej miejska $w$ Łodzi...

66 J. Wesołowski, Ukształtowanie kolejowego węzła łódzkiego..., s. 46.

${ }^{67}$ A. Drożyńska i in., Przesłanki rozwoju Łodzi..., s. 70-71. 
śródmieścia, który się obecnie dokonuje za sprawą położonych na peryferiach miasta punktów handlowo-rozrywkowych ${ }^{68}$.

Szansa dla regionu jest również utworzenie $w$ Łodzi centrum serwisowego dla polskich szybkich kolei. Wybrany wariant przebiegu KDP zakłada, iż przez Łódź będa prowadziły wszystkie przewidywane połączenia. Stąd też wydaje się, iż usytuowanie właśnie w Łodzi takiego centrum jest wyjściem optymalnym. Serwis obsługujący superekspresy będzie musiał się wyróżniać najwyższym poziomem usług ze względu na bezpieczeństwo podróży w pociągach rozwijających tak duże prędkości. Dla regionu oznacza to nowe miejsca pracy dla specjalistów oraz dodatkowe inwestycje w zaawansowane technologie ${ }^{69}$. Wskazuje się dwa warianty umiejscowienia centrum logistycznego i stacji utrzymania taboru KDP ${ }^{70}$ :

- na północ od budynku stacji Łódź Widzew, za torowiskiem, gdzie obecnie znajduja się pola uprawne i nieużytki. Największą zaletą tej lokalizacji jest położenie na trasie szybkiej kolei - zaraz przy dworcu. $Z$ drugiej strony, może pojawić się problem z pozyskaniem odpowiedniej przestrzeni pod zabudowę tego typu,

- w miejscu, gdzie obecnie znajduje się stacja przeładunkowa Łódź Olechów. Pociągi musiałyby zjeżdżać z głównej trasy, za stacja Łódź Widzew, na południowy tor, prowadzący obrzeżami Łodzi do stacji towarowej. Zaleta tej lokalizacji jest to, że służy do obsługi kolei od lat - wystarczyłoby przystosować infrastrukturę do szybkich pociagów. Wada natomiast jest fakt, iż obecnie jest to największa stacja rozładunkowa dla pociągów towarowych w Łodzi i takie centrum mogłoby zmniejszyć jej przepustowość.

Kolej dużych prędkości to szansa nie tylko dla Łodzi i miast, przez które będzie przebiegać. Realizacja tego projektu pokazuje, iż Polska jest nowoczesnym, rozwiniętym krajem, który standardami chce dorównać zachodnioeuropejskim sąsiadom. Sieć szybkiej kolei połączy wszystkie najważniejsze ośrodki w państwie, co zwiększy spójność gospodarczą i społeczną. Sprawna komunikacja pobudzi przedsiębiorczość, zachęci do otwierania oddziałów i filii w innych miastach - nawet odległych, wzrośnie również mobilność ludności (obecnie jedna z najniższych $\mathrm{w} \mathrm{UE}^{71}$ ). Polska stanie się bardziej interesującym miejscem dla inwestorów zagranicznych i łatwiej dostępnym dla turystów.

${ }^{68} \mathrm{~J}$. Wesołowski, Ukształtowanie kolejowego węzła łódzkiego..., s. 43.

69 M. Kudlicka, Kolej XXI wieku...

${ }^{70}$ Stowarzyszenie Inżynierów i Techników Komunikacji RP Oddział w Łodzi, Studium rozwoju funkcjonalnego...

${ }^{71}$ Raczyński J., Rządowy program budowy..., s. 21. 


\section{Podsumowanie}

Celem rozdziału było ukazanie, jak ważną kwestia dla prawidłowego rozwoju aglomeracji jest odpowiednia infrastruktura kolejowa. Rozważania prowadzono na przykładzie Łodzi, w której, ze względów politycznych i ekonomicznych, powstał węzeł kolejowy niedostosowany do potrzeb przewozowych mieszkańców oraz uniemożliwiający rozwój miasta do funkcji metropolii o znaczeniu międzynarodowym. Autorka wysnuwa wniosek, iż brak odpowiedniej infrastruktury kolejowej jest jedna z przyczyn obecnej stagnacji gospodarczej oraz odpływu mieszkańców miasta do innych polskich aglomeracji. Łódź, którą do tej pory omijały wszystkie najważniejsze szlaki komunikacyjne (zarówno kolejowe, jak i drogowe), stała się miastem nieatrakcyjnym dla inwestorów, nieodwiedzanym przez turystów, znajdującym się w cieniu Warszawy - zbyt blisko, by być samodzielnie ważnym ośrodkiem i zbyt daleko, by pełnić funkcje "pomocnicze" stolicy.

Z zebranego w toku badań materiału i dokonanej analizy wynika, że szansą dla Łodzi byłoby włączenie jej w projektowaną sieć kolei dużych prędkości. Wraz z planem budowy autostrad i dróg ekspresowych, przebiegajacych $\mathrm{w}$ pobliżu miasta oraz rozbudowy portu lotniczego uda się stworzyć odpowiednią infrastrukturę komunikacyjna, służącą rozwojowi Łodzi.

Jedyna możliwościa przeprowadzenia linii szybkiej kolei przez Łódź jest budowa tunelu średnicowego, łączącego dworce Łódź Fabryczna i Łódź Kaliska. W rozdziale wskazano również wiążące się z tą budową dodatkowe inwestycje, obejmujące przebudowę stacji Łódź Fabryczna na dworzec podziemny czy utworzenie Nowego Centrum Łodzi.

Na podstawie rozważań dotyczących budowy tunelu średnicowego można sformułować następujące wnioski:

a) dzięki tunelowi średnicowemu Łódź stanie się centralnym punktem na mapie kolejowej Polski, w którym będą przecinać się szlaki z północy na południe oraz ze wschodu na zachód. Łódź będzie pełnić funkcję obsługi ruchu tranzytowego, przy okazji czerpiąc korzyści z wygodnej, z dużą częstotliwością, obsługi miasta i regionu oraz dostępu do międzynarodowych połączeń kolejowych,

b) tunel średnicowy może zostać wykorzystany do rozwoju sieci kolei aglomeracyjnej, która zapewni szybki dojazd do śródmieścia z dzielnic znajdujących się na obrzeżach miasta (jednocześnie przyczyniając się do ograniczenia kongestii w centrum), jak również zwiększy spójność całego regionu, poprzez doprowadzenie kolei również do miejscowości położonych z dala od stolicy województwa, 
c) budowa tunelu doprowadzi do rewitalizacji śródmieścia Łodzi, pozbycia się upadających kamienic, budynków pofabrycznych i stworzenia nowoczesnego centrum kulturowego, biznesowego i handlowo-usługowego wokół dworca Łódź Fabryczna,

d) za sprawą tunelu Łódź będzie centralnym punktem krajowej sieci szybkiej kolei - przez nią będa prowadziły wszystkie najważniejsze trasy. Dworzec Łódź Fabryczna w 2040 r. ma obsługiwać dziennie na 170 tys. pasażerów ${ }^{72}$. Dla miasta to szansa, aby zatrzymać pasażerów w mieście - zapewnić im nocleg, dostarczyć dóbr i usług, których potrzebuja. W Łodzi ma również zostać zlokalizowane centrum serwisowe dla taboru polskiej kolei wysokich prędkości. Takie perspektywy spowodują ożywienie gospodarcze w regionie i przyczynia się do powstania nowych miejsc pracy,

e) dzięki wprowadzeniu kolei dużych prędkości do Łodzi, stanie się ona jednym z najważniejszych ośrodków na mapie transportowej całej Europy. Ten fakt przyciagnie do miasta zagranicznych inwestorów, turystów oraz międzynarodowe instytucje i organizacje.

Konkludując, sieć szybkiej kolei można przyrównać do krwioobiegu w organizmie człowieka: rozprowadza potrzebne zasoby po całym terytorium państwa w sposób szybki, bezpieczny i niezawodny. Pomyśleć, że Łódź miałaby się stać sercem tego układu - jakaż wiąże się z tym odpowiedzialność, ale i jaki prestiż oraz niezmierzone szanse i możliwości...

72 www.ec1lodz.pl/aktualnosci.php?news_id=42 [z dn. 1.03.2010]. 


\section{Tunel średnicowy w Lipsku i kodzi}

Marek Przybylak*

\subsection{Historia Węzła Lipskiego}

Miasto Lipsk już od początku istnienia niemieckiego systemu kolejowego stanowiło na jego mapie bardzo istotne ogniwo. Było drugim miejscem w Niemczech (patrząc z perspektywy obecnego podziału politycznego państwa), które wprowadziło kursujące składy na swoje tereny. Dokładnie 24 kwietnia 1837 r. otworzono trasę kolejową łączącą Lipsk z miastem Althen, która dwa lata później przedłużona została aż do Drezna. Przedłużenie linii zajęło dwa lata. W 1839 r. linia długości 120 km stała się pierwszą w Niemczech linią dalekiego zasięgu. Co ciekawe, zawierała ona w sobie także pierwszy tunel, przez który swobodnie mogły przejeżdżać pociagi niemieckich linii kolejowych. Również w roku 1839 do Lipska dotarła druga z dalekobieżnych linii budowanych w tamtych czasach na terenie Niemiec. Tym samym już w okolicach połowy XIX wieku Lipsk stanowił jeden z głównych ośrodków transportu kolejowego Niemiec. Niedługo trzeba było czekać na rozwój infrastruktury kolejowej na terenie miasta. Około 3 lata po „wejściu” do miasta drugiej linii dalekiego zasięgu w historii Niemiec, w Lipsku otwarto pierwszy dworzec kolejowy o nazwie Bayerischer Bahnhof (Dworzec Bawarski). Jednocześnie był to pierwszy dworzec otwarty na terenie państwa niemieckiego. Niestety, w chwili obecnej Dworzec Bawarski tworzy swoista ikonę prezentującą historię kolei w Niemczech. Od dłuższego czasu był on bezużyteczny, jednak z poczatkiem XXI wieku może znów wejść w skład systemu transportowego kolejowego węzła Lipsk. Jest to zwiazane z projektem określanym mianem City Tunnel Leipzig ${ }^{1}$, czyli tunelem średnicowym, który ma być usytuowany pod ulicami Lipska, a którego elementem będzie Bayerischer Bahnhof, kończąc trasę średnicówki w Lipsku. Więcej informacji o projekcie tunelu średnicowego City Tunnel Leipzig w podrozdziale 4.2 .

${ }^{*}$ Mgr Marek Przybylak - Katedra Logistyki, Wydział Zarządzania Uniwersytetu Łódzkiego, ul. Matejki 22/26, 90-237 Łódź.

${ }^{1}$ www.leipzig.de/int/pl/stadt_leipzig/infrastruktur/schienenverkehr [zdn. 11.10.2012]. 
Z biegiem czasu Lipsk zyskiwał coraz to nowe połączenia kolejowe z wybranymi niemieckimi miastami. Pociągi zaczęły podróżować w każdą stronę państwa, a kolej cieszyła się takim zainteresowaniem, że powoli zaczęto odczuwać zjawisko kongestii zarówno w samych pociągach, jak i obiektach infrastrukturalnych. Zaowocowało to tym, iż w roku 1902 władze miasta zdecydowały się na budowę zupełnie nowego dworca kolejowego, który miał w niedalekiej przyszłości stać się centralnym dworcem Lipska². Wraz z budowa nowego dworca Niemcy zaczęli stopniowo elektryfikować swoje linie kolejowe. Można powiedzieć, że byli prekursorami, jeżeli idzie o nadawanie swym pociągom napędu prądowego. Kolejna istotna data w historii niemieckich kolei to rok 1915. Wtedy właśnie zakończyła się elektryfikacja linii kolejowych, co zbiegło się również z otwarciem nowego dworca Lipsk Główny (niem. Leipzig Hauptbahnhof)3. Dworzec jak na ówczesne czasy (początek XX wieku) zaskakiwał wszystkich swoimi rozmiarami. Po oddaniu do użytku zawierał w sobie 31 peronów, z których tylko 5 znajdowało się poza hala peronowa. W skład całego kompleksu dworca głównego wchodził też budynek dworcowy o długości 298 metrów ${ }^{4}$.

Władze miasta jeszcze przed planami budowy dworca Leipzig Hauptbahnhof zastanawiały się nad budową linii średnicowej pod miastem, aby udostępnić przejazd składom jadącym z Berlina na południe Niemiec. Jednak dopiero na początku wieku XX rozpoczęto prace projektowe (1909 r.). Natomiast sama budowa rozpoczęła się w roku 1913 i trwała około rok czasu. W roku 1914 prace ustały, pozostawiajac następujące elementy planowanego tunelu:

- 140-metrowy kawałek tunelu,

- 675 m tunelu pod torami nr 22 i 23, znajdujacego się pod dworcem Lipsk Główny,

- peron długości $40 \mathrm{~m}$.

Sytuacja polityczna, jaka miała miejsce w końcówce pierwszego dwudziestolecia XX wieku zmusiła Lipsk oraz jego władze do zaprzestania budowy tunelu. Również okres międzywojenny nie wpłynął w żaden sposób na postęp prac związanych z linia średnicową łącząca dwa lipskie dworce.

Początek lat 50. XX stulecia to czas, w którym znaczna część funduszy, jakimi dysponowało miasto, została przekazana na odbudowę zniszczeń związanych z II wojna światowa. Po jej zakończeniu ponownie zainstalowano sieć trakcyjna, którą zdemontowano na czas wojny.

\footnotetext{
2 http://inforail.pl/text.php?id=16710 [z dn. 11.10.2012].

3 Tamże.

${ }^{4}$ Tamże.
} 
Niestety, w wyniku prowadzonych działań wojennych ucierpiał dworzec Lipsk Główny.

Jednak zastrzyk kapitału, jaki otrzymała gospodarka niemiecka zaraz po zakończeniu wojny, spowodował szybką odbudowę dworca oraz wznowienie planów dotyczących budowy tunelu średnicowego. Strategia zakładała wybudowanie pod miastem dwóch równoległych rur, w których miałyby jeździć pociągi. Jedna trasa dotyczyć miała połączeń typu S-Bahn ${ }^{5}$, a druga linii dalekiego zasięgu, biegnących na południe w kierunku Monachium. Niestety, po raz kolejny dała o sobie znać polityka oraz podział Niemiec na dwa oddzielne państwa: Republikę Federalną Niemiec i Niemiecką Republikę Demokratyczną. W związku z tym prace przy projekcie tunelu były dalej prowadzone tylko i wyłącznie w kontekście systemu S-Bahn. W tym miejscu pojawił się kolejny problem. Tym razem zaczęło brakować funduszy na prowadzenie prac projektowych i ewentualnych prac budowlanych. Po podziale Niemiec na dwa państwa większość kapitału pozostała po zachodniej stronie, w związku z czym biedne NRD nie było sobie w stanie poradzić z pozyskaniem pieniędzy na wprowadzenie $\mathrm{w}$ życie tak kosztownego lipskiego projektu. Po upadku komunizmu w znacznej części państw europejskich przemiany nastapiły również w Niemczech. Zburzono mur berliński i doszło do zjednoczenia Niemiec. Zmianom musiały poddać się także koleje niemieckie: wschodnie DR (Deutsche Reichsbahn) połączyły się z DB (Deutsche Bahn). Znaczny przypływ środków pieniężnych spowodował także całkowitą modernizację dworca Lipsk Główny. Niestety, na kolejne lata znowu zawieszono program budowy tunelu, ponieważ priorytetem były sprawy polityczne związane z połączeniem się RFN i NRD oraz ujednolicenie wszystkich systemów, tak aby Niemcy mogły funkcjonować ponownie jako jednolite państwo bez podziałów. Jednak prace przy projektowaniu tunelu dla kolei S-Bahn były prowadzone cały czas, co zaowocowało uzyskaniem pozwolenia na budowę w 2003 r. Wreszcie projekt City Tunnel Leipzig ujrzał światło dzienne.

\subsection{City Tunnel Leipzig, czyli projekt związany z budową tunelu średnicowego w Lipsku}

Projekt City Tunnel Leipzig w stadium projektowania został podzielony na etapy. Można wyróżnić trzy główne elementy składowe, które

${ }^{5}$ S-Bahn - niemiecki system kolei obsługującej aglomeracje miejskie (http://encyklopedia.pwn.pl/haslo.php?id=3970811 [z dn. 11.10.2012]). 
w 2011 r. utworzyły spójną całość City Tunnelu6. Odcinki budowanego tunelu przedstawiały się następująco:

- odcinek A - specjalne rampy przy wejściu tunelu średnicowego w kierunku dworca Lipsk Główny,

- odcinek B - całościowy obszar linii średnicowej znajdujący się pomiędzy planowanymi miejscami wejścia i wyjścia (czyli Leipzig Hauptbahnhof i Bayerischer Bahnhof) oraz cztery przystanki podziemne,

- odcinek C - budowa wlotu tunelu od strony Dworca Bawarskiego dodatkowo ze znajdująca się nad ziemia stacja Semmelweisstraße.

Prace budowlane przy poszczególnych stacjach wjazdowych zaczęły się w latach 2004-2005. Wcześniej rozpoczęto budowę od strony Dworca Bawarskiego, przechodząc później na północ w rejon Dworca Głównego. Prace prowadzone stricte przy wierceniu tunelu rozpoczęły się rok później i trwały aż do 2008 r. Projektanci całej inwestycji założyli sobie, że tunel przystosowany będzie do obsługi każdego typu pojazdów szynowych, zaczynając od składów SKM (Szybka Kolej Miejska) oraz pojazdów regionalnych, na pociągach dalekiego zasięgu oraz ICE ${ }^{8}$ kończąc. Twórcy pomysłu City Tunnel Leipzig założyli, że linia średnicowa będzie się składać z dwóch jednakowych podziemnych rur o średnicy $9 \mathrm{~m}$ każda9. Oczywiście linia ta podlega całkowitej elektryfikacji, tak aby pociągi cały czas miały możliwość efektywnego hamowania, jak i systematycznego przyspieszania, ruszając z poszczególnych stacji przystankowych. Całkowita długość powstającego podziemnego kolejowego szlaku szacowana jest na ok. 5300 m, natomiast sama długość tunelu podziemnego wraz z rampami oraz stacjami przesiadkowymi wynosi około $4 \mathrm{~km}^{10}$. Znaczna część podziemnego korytarza drążona była przy pomocy metody tzw. TBM, czyli Tunnel Boring Machine. Do wykopu ziemi w Lipsku użyto tarczy wiercącej, którą nazwano Leoni ${ }^{11}$. Jest to ogromna tarcza tunelowa, której długość wraz z całym niezbędnym osprzętem wynosi około $65 \mathrm{~m}$. Natomiast średnica tarczy wiercącej wynosi nieco ponad 9,5 m. Waga całego urządzenia TBM wynosi około $1100 \mathrm{t}$ (z czego około 60\% ciężaru zajmuje tarcza wiercąca). Mimo swoich olbrzymich rozmiarów oraz nieprzeciętnej wagi Leoni nie była w stanie poradzić sobie $z$ różnorodnością geologiczna, jaką spotkała na swojej drodze. Z uwagi na występowanie żwiru, skał, piasku, a nawet małych złóż

\footnotetext{
${ }^{6}$ www.railway-technology.com/projects/leipzig_tunnel [z dn. 11.10.2012].

7 www.nbi.com.pl/city-tunnel-leipzig-2 [z dn. 11.10.2012].

${ }^{8}$ www.bahn.de/i/view/POL/pl/trains/overview/ice.shtml [z dn. 11.10.2012]

${ }^{9}$ www.nbi.com.pl/city-tunnel-leipzig-2 [z dn. 11.10.2012].

${ }^{10}$ www.citytunnelleipzig.de [z dn. 11.10.2012].

${ }^{11}$ www.railway-technology.com/projects/leipzig_tunnel [z dn. 11.10.2012].
} 
węgla Leoni była wspomagana hydraulicznie poprzez utworzenie nadciśnienia w rejonie aktualnie drążonego fragmentu tunelu. Po ukończeniu wytłaczania materiałów z terenów podziemnej linii średnicowej, cały nowo powstały tunel obudowano warstwa technicznie określana jako tubing ${ }^{12}$. Nie zagłębiając się w szczegóły inżynieryjne, można w skrócie powiedzieć, że tubingi instalowane były poprzez płaszcz tarczy wiercącej. W momencie wywiercenia każdego kolejnego fragmentu tunelu, w odpowiednim miejscu instalowany był odpowiedni element wykończeniowy. Każdy tubing ma grubość $40 \mathrm{~cm}$. Aby uniknąć zalania średnicówki przez wody gruntowe, uszczelniono przestrzeń pomiędzy kolejnymi betonowymi pierścieniami. Do wykonania stanu surowego tunelu zużyto około 13 tys. betonowych pierścieni, z których każdy ważył mniej więcej 47 t. Te liczby pokazuja, jak ogromnym przedsięwzięciem jest budowa obiektu infrastrukturalnego, który stanowi kolejowy tunel średnicowy. Jednym z ważniejszych problemów, na jakie natrafili inżynierowie oraz inne osoby odpowiedzialne za budowę lipskiej trasy średnicowej było osiadanie gruntu. Można powiedzieć, iż zjawisko to zachodzi z intensywnościa odpowiadająca środowisku (chodzi tu o rodzaj podłoża), w jakim prowadzone sa działania mające na celu budowę tunelu. Osiadanie gruntu ma istotne znaczenie dla budynków oraz elementów architektonicznych znajdujących się bezpośrednio nad tunelem, na ziemi. Dlatego też jeszcze przed rozpoczęciem działań przez maszynę TBM wszystkie budynki w sasiedztwie prowadzonych robót zostały sprawdzone właśnie pod katem zjawiska osadzania się gruntu. Aby w jak największym stopniu zniwelować negatywne działanie zachodzące w omawianej sytuacji, budowniczy zastosowali metodę podnoszenia gruntu, zwaną z ang. compensations grouting ${ }^{13}$. Całe działanie oparte na compensations grouting można podzielić na cztery zasadnicze fazy działań:

- faza I - oparta jest na skutecznym załataniu przerwy, która uwidoczniła się podczas wybierania ziemi,

- faza II - następuje całkowicie kontrolowane podnoszenie się podłoża,

- faza III - ewentualne wykonywanie iniekcji ${ }^{14}$ w celu uniknięcia osiadania budowli znajdujących się na powierzchni ziemi,

- faza IV - wykonanie pozostałych wyrównań powierzchni gruntu przy drążeniu.

Na początku niniejszego podrozdziału zaprezentowano podział poszczególnych etapów realizacji City Tunnel Leipzig. Wymienione wyżej

12 J. Z. Mirski, Budownictwo z technologia, Wyd. Szkolne i Pedagogiczne, Warszawa 1995, s. 57-67.

${ }^{13}$ www.nbi.com.pl/city-tunnel-leipzig-2 [z dn. 11.10.2012].

${ }^{14}$ Iniekcja - wtłaczanie, wtryskiwanie cieczy lub gazów za pomoca pompy lub innego urządzenia ciśnieniowego (Słownik wyrazów obcych, PWN, Warszawa 1993, s. 366). 
działania dotyczą stricte części B, ponieważ pozostałe dwa etapy obejmuja działania budowlane, które nie sa interesującym zagadnieniem do przedstawienia. Natomiast w dalszej części punktu B zostały zawarte informacje o planowanych czterech stacjach przystankowych. Na trasie tunelu średnicowego w Lipsku znajduja się właśnie cztery miejsca, w których zatrzymywać się będą głównie pociągi regionalne typu S-Bahn. Sa to następujące stacje:

- Lipsk Główny,

- Market,

- Plac Wilhelma-Leuschnera,

- Dworzec Bawarski.

Dodatkową stacja, na której zatrzymywać się będą pociaggi (aczkolwiek nie wszystkie) jest Semmelweisstraße, która stanowi wyjście tunelu średnicowego $\mathrm{w}$ kierunku południowym. Jeżeli chodzi o dane techniczne każdej z platform (za wyjątkiem stacji Semmelweisstraße), to każda z nich posiada peron typu wyspowego, który usytuowany będzie centralnie w stosunku do torów przebiegajacych przez stację peronowa. Wyjatkiem jest tu właśnie Semmelweisstraße, gdzie platformy dla pasażerów znajduja się po przeciwnych stronach stacji. Każda ze stacji ma długość 140 m. Jedynie stacja na dworcu Lipsk Główny będzie miała inna długość, równą $215 \mathrm{~m}$. Istnieje także możliwość ewentualnego przedłużenia jej do opcjonalnych 400 m, jednak inżynierowie nie zakładaja, aby taka ewentualność miała miejsce.

Jeżeli chodzi o budowę stacji, to przebiegała ona dwuetapowo. Niestety, nie obyło się bez wielkich utrudnień komunikacyjnych, ponieważ wszystkie stacje znajduja się w centrum miasta, blisko ogromnie uczęszczanych ulic. W związku z tym część z nich, na czas budowy, musiała zostać zamknięta, co nie spotkało się z pozytywną reakcją mieszkańców Lipska. Prace prowadzone były tzw. metodą wykopu otwartego. Można powiedzieć, iż najpierw została wybudowana bryła w ziemi, która stanowiła strop, ściany boczne oraz podłogę stacji. Dopiero później prace były prowadzone w środku nowo powstałego surowego obiektu (pod ziemia), a robotnicy ponownie udostępnili naprawione ulice do dyspozycji kierowców.

Przy inwestycji związanej z projektem City Tunnel Leipzig nie sposób nie wspomnieć o kwestii finansowania inwestycji. W Niemczech jest to wielce kontrowersyjny temat, gdyż zarzuca się władzom Lipska znaczne przekroczenie budżetu przewidzianego na inwestycję. Te jednak odpieraja zarzuty, zasłaniając się korzyściami, jakie przyniesie tunel średnicowy niedługo po oddaniu go do użytku. Z danych na rok 2003, zawartych na oficjalnej stronie internetowej lipskiej linii średnicowej,można wyczytać, że całkowity koszt projektu to suma rzędu 571,62 mln euro. 
W tab. 5 przedstawione zostały poszczególne źródła finansowania tej bardzo kosztownej inwestycji ${ }^{15}$.

Tabela 5. Partycypacja w kosztach budowy tunelu średnicowego w Lipsku

\begin{tabular}{|l|c|}
\hline \multicolumn{1}{|c|}{ Partycypant } & Kwota \\
\hline Land Saksonia i miasto Lipsk & 194800000 \\
\hline $\begin{array}{l}\text { Unia Europejska } \\
\text { (pieniądze pochodzące z Europejskiego } \\
\text { Funduszu Rozwoju Regionalnego) }\end{array}$ & 168730000 \\
\hline $\begin{array}{l}\text { Rząd Niemiec (z programu rozwojowego } \\
\text { kolei w Niemczech) }\end{array}$ & 114530000 \\
\hline $\begin{array}{l}\text { Rząd Niemiec (z programu } \\
\text { o finansowaniu transportu publicznego) }\end{array}$ & 77200000 \\
\hline Deutsche Bahn AG & 16360000 \\
\hline
\end{tabular}

Źródło: opracowanie własne na podstawie danych z: www.citytunnelleipzig.de [z dn. 11.10.2012].

Jeżeli chodzi o wyżej wspomniane argumenty, jakimi posługiwały się władze, to chodziło głównie o zmniejszenie przejeżdżanych dziennie przez samochody kilometrów o 320 000. Jednocześnie ludzie dużo chętniej zaczęliby korzystać z komunikacji publicznej. Dodatkowo, mieszkańcy okolicznych miejscowości mieliby ułatwiony dostęp do dużego miasta, jakim niewatpliwie w regionie Saksonii jest Lipsk. Bez problemów mogliby dostać się za pomocą kolei bezpośrednio do centrum, które oferuje dla przyjezdnych wiele atrakcji (kulturalnych, rozrywkowych itp.). Budowa City Tunnel Leipzig zapewni także mieszkańcom miasta i regionu ułatwiony dostęp do kolei dużych prędkości, które mkną z Berlina na południe kraju. Z czysto ekonomicznego punktu widzenia projekt tunelu średnicowego w perspektywie czasu daje zatrudnienie dla około 1500 osób, na stałe poprawiając ich sytuację materialną.

Niewątpliwie tunel średnicowy pod ulicami Lipska to projekt na miarę XXI wieku i jednocześnie jedno z największych przedsięwzięć kolejowych w historii Niemiec. W świetle wymienionych wyżej argumentów nie można było sobie wyobrazić, iż jego budowa mogłaby się w ogóle nie rozpocząć. Idąc za przykładem naszych zachodnich sąsiadów, Polska ma nadzieję, że za parę lat podobny entuzjazm i optymizm panować będzie w Łodzi, gdzie już w niedalekiej przyszłości ma rozpoczać się budowa linii średnicowej pod ulicami miasta. Dziać ma się tak ze względu na wprowadzenie przez władze państwa 
programu dotyczącego kolei dużych prędkości, który niewątpliwie jest Polsce potrzebny. Więcej informacji na ten temat w kolejnym rozdziale.

\subsection{Projekt budowy tunelu średnicowego pod ulicami Łodzi}

Łódź jako miasto położone centralnie na terytorium Polski jest miejscem doskonałym do korzystania z rozbudowy infrastruktury kolejowej i drogowej, jaka ma miejsce w ostatnich latach na terenie Polski (momentem przełomowym w tej kwestii było wejście Polski w 2004 r. do Unii Europejskiej). Powstające autostrady A1 i A2 oraz drogi ekspresowe S8 i S14 stanowią podstawę do rozwoju wielkich centrów logistycznych w Łódzkiej Specjalnej Strefie Ekonomicznej, która jest najlepsza tego typu jednostka biznesowa w kraju ${ }^{16}$. Niestety, mimo dość korzystnej sieci drogowej miasto posiada do chwili obecnej bardzo niekorzystny układ torowy. Taka lokalizacja infrastruktury kolejowej powoduje, iż Łódź nie wykorzystuje swojego maksymalnego potencjału, wynikającego z położenia geograficznego. Głównym mankamentem zaistniałej sytuacji jest brak bezpośredniego połączenia pomiędzy głównymi łódzkimi dworcami, czyli Łodzią Fabryczną oraz Łodzią Kaliska. Brak możliwości przejechania przez miasto bez przesiadania się jest bolączką Łodzi od wielu lat. Zmieniające się co cztery lata rządy zapewniały, że dokonaja wszelkich starań, aby w możliwie krótkim czasie zmodernizować i udoskonalić system kolejowy w Łodzi. Jednak wszystkie plany pozostawały w sferze marzeń i stanowiły tylko elementy gry politycznej.

Sytuacja zmieniła się po przystapieniu Polski do Unii Europejskiej. Związane jest to w głównej mierze z napływem do kraju zagranicznego kapitału, który Unia przeznacza na dostosowanie i modernizację różnych gałęzi transportu nowych krajów członkowskich, aby w najefektywniejszym stopniu ujednolicić europejski system transportowy. Dzieje się tak zarówno w transporcie drogowym, poprzez tworzenie wielkich korytarzy autostradowych, jak i w transporcie kolejowym, poprzez łączenie wybranych linii danych krajów w transeuropejskie sieci. Nie inaczej jest w przypadku Polski, gdzie po wejściu do Wspólnoty powstał pomysł zbudowania systemu szybkich kolei łączących największe polskie miasta.

Pieniądze otrzymane z Unii Europejskiej zachęciły władze państwa oraz władze lokalne do przystapienia do projektu pod nazwą "Kolej

${ }^{16}$ http://gospodarka.gazeta.pl/gospodarka/1,93545,5876005.html [z dn. 5.02.2010]. 
Dużych Prędkości V-300"17. Już na wstępnym etapie prac okazało się, że sercem projektu będzie Miasto Łódź, gdyż linia dużych prędkości nie może ominąć drugiej co do wielkości aglomeracji w Polsce. Na szczęście miasta oraz jego mieszkańców taka opinia została pozytywnie zaakceptowana przez wszystkie osoby, którym powierzono odpowiedzialność za prawidłowe wykonanie projektu. Istotny wpływ na decyzję o poprowadzeniu kolei dużych prędkości miała mediacja bezpośrednio ze strony Ministra Infrastruktury Cezarego Grabarczyka, który wywodzi się z Łodzi i dla którego to miasto jest oczkiem w głowie jeżeli idzie o inwestycje infrastrukturalne. Jednak aby cała inwestycja zakończyła się powodzeniem, w Łodzi musi powstać bezpośrednie połączenie pomiędzy dwoma dworcami, aby realizacja KDP (kolei dużych prędkości) w ogóle miała szansę powodzenia. W ten oto sposób miasto musi przystapić do budowy tunelu średnicowego, który jest jedyną racjonalną opcją dla połączenia wymienionych dworców.

Łódź jak się okazuje już na samym początku realizacji największego projektu w dziejach polskiego kolejnictwa stanęła na wysokości zadania. Nie trzeba było długo czekać na dokument określający etapy, koszt oraz parametry budowy tunelu. W 2006 r. na zlecenie Zarządu Dróg i Transportu w Łodzi powstało Studium przebiegu przez Łódź Kolei Dużych Prędkości V-300 wykonane przez spółkę Teren. W studium opisane sa poszczególne etapy realizacji inwestycji, warianty lokalizacyjne dla tunelu, jego parametry oraz metoda wykonania. Jednak nie tylko KDP jest celem budowy trasy średnicowej pod ulicami miasta. Celami drugorzędnymi (lecz odgrywającymi bardzo ważną rolę w transporcie kolejowym aglomeracji łódzkiej) są: osiagnięcie harmonizacji transportu miasta i jego okolic oraz komunikacji wewnętrznej ${ }^{18}$. Pierwszy z celów odnosi się do regionalnych linii kolejowych, które po wybudowaniu tunelu mogłyby bez problemu przejeżdżać pod miastem, a pasażerowie korzystający z podmiejskich połączeń, chcąc przedostać się z miast położonych po dwóch stronach metropolii, mogliby mieć taką możliwość bez konieczności opuszczania składu pociągu lub przesiadania się chociażby do pojazdów Miejskiego Przedsiębiorstwa Komunikacji. Cel związany z integracją komunikacji wewnątrz miasta polega na tym, iż $\mathrm{w}$ perspektywie budowy tunelu średnicowego $\mathrm{w}$ Łodzi powstałaby szybka kolej aglomeracyjna, która połączyłaby miasta ościenne, takie jak chociażby Zgierz czy Pabianice z centrum stolicy województwa.

17 Studium przebiegu przez Łódź Kolei Dużych Prędkości V-300, TEREN Sp. z o.o., Łódź 2006.

18 Tamże. 
Warto w tym miejscu wspomnieć, iż tunel średnicowy znajdował się w planach Łodzi już po I wojnie światowej. Niestety, szybkie nadejście kolejnego światowego konfliktu zmusiło władze do odstapienia od projektu, do którego powrócono dopiero w latach 60. Plany zakładały budowę centralnego dworca dla miasta, który miał być zlokalizowany około $1 \mathrm{~km}$ na północ od obecnej lokalizacji dworca Łódź Fabryczna. W roku 1968 powstał nawet projekt całego przedsięwzięcia, jednak podobnie, jak to miało miejsce przed II wojną światowa, od planów odstapiono aż do początku XXI wieku ${ }^{19}$, kiedy to pojawił się projekt związany z koleją dużych prędkości w Polsce.

Jako datę, która na stałe weszła do kalendarium przedsięwzięcia (można powiedzieć, iż przesądziła o przyszłym wykonaniu inwestycji, jakim jest tunel średnicowy), należy uznać 26 września 2009 r. Wtedy właśnie w budynku spółki EC-1 zostało podpisane wielostronne porozumienie pomiędzy Miastem Łódź, PKP Polskie Linie Kolejowe S.A. oraz EC-1 Łódź - Miasto Kultury, którego przedmiotem jest wykonanie linii średnicowej pod ulicami Łodzi ${ }^{20}$. Na owym zebraniu obecni byli także przedstawiciele województwa łódzkiego z marszałkiem Włodzimierzem Fisiakiem na czele. Przedmiotem porozumienia stron jest umowa o wykonanie studium wykonalności dla linii średnicowej, która w niedalekiej przyszłości ma połączyć dworce Kaliski i Fabryczny, jednocześnie umożliwiając poprowadzenie pod ulicami Łodzi kolei dużych prędkości, linii regionalnych obsługiwanych przez PKP oraz kolei aglomeracyjnej, łączacej największe miasta okręgu łódzkiego ${ }^{21}$. Co więcej, umowa zawarta pomiędzy wymienionymi stronami zakłada wykonanie wszechstronnej analizy i przygotowania dokumentacji, dotyczącej takich aspektów, jak: oddziaływanie na środowisko, czynniki archeologiczne, najdogodniejsza lokalizacja pod miastem czy wnioski o dofinansowanie inwestycji z kasy Unii Europejskiej, bez której idea tunelu średnicowego w Łodzi przez długie lata pozostawałaby w sferze marzeń.

Jak można wyczytać z informacji opublikowanych również dnia 26 września 2009 r., studium wykonalności dla przedmiotu zamówienia, jakim jest tunel średnicowy, miało być wykonane w nieprzekraczalnym terminie końca 2011 r. $^{22}$ Realizacja ogólnonarodowego planu kolei du-

${ }^{19}$ Stowarzyszenie Inżynierów i Techników Komunikacji RP, Analiza warunków budowy kolejowego tunelu średnicowego pod centrum Łodzi - podsumowanie i wnioski, Łódź 2008, s. 2.

${ }^{20}$ www.ec1lodz.pl/aktualnosci.php?news_id=42 [z dn. 26.09.2009].

${ }^{21}$ Porozumienie $w$ sprawie realizacji studium wykonalności dla tunelu średnicowego, Miasto Łódź, PKP Polskie Linie Kolejowe S.A., EC-1 Łódź - Miasto Kultury, Łódź, 26.09.2009.

22 http://uml.lodz.pl/index.php?str=1732\&id=17249 [z dn. 26.11.2011]. 
żych prędkości miałaby ruszyć w okolicach 2014 r., kiedy to prace nad łódzkim tunelem średnicowym oraz cała okalająca infrastrukturą zostałyby zakończone.

\subsection{Metoda wykonania tunelu, jego parametry, warianty budowy i kwestia finansowania}

Podrozdział opracowany jest na podstawie Studium przebiegu przez Łódź Kolei Dużych Prędkości V-300 oraz Analizy warunków budowy kolejowego tunelu średnicowego pod centrum Łodzi. Oba dokumenty wykonane były na zlecenie Zarządu Dróg i Transportu w Łodzi przez firmy Teren sp. z o.o. oraz Stowarzyszenie Inżynierów i Techników Komunikacji RP, Oddział w Łodzi.

Łódzki tunel średnicowy swój początek będzie miał dopiero wtedy, gdy zmieni się zagospodarowanie obecnego terenu dworca Łódź Fabryczna. Oznacza to przeniesienie samego dworca pod ziemię w celu umożliwienia rozpoczęcia prac podziemnych przy budowie linii średnicowej pod ulicami miasta. Jednak sama budowa, a raczej sposób jej wykonania, wśród wielu osób wzbudza kontrowersje. Związane jest to z obawą (głównie okolicznych mieszkańców), że centrum na czas budowy, czyli lata 2010-2014, zmieni się w jeden wielki park maszyn. Dlatego też miasto dokonało szerokiej analizy metod budowania obiektów, jakimi sa tunele podziemne i spośród nich wybrało dwie, których główną zaletą jest oszczędność finansowa. Oznacza to największe korzyści z punktu widzenia ekonomicznego dla miasta.

Wybór optymalnej metody konstruowania tunelu musiał opierać się na dwóch podstawowych analizach. Pierwszą z nich jest dokładne określenie warunków geologicznych na obszarze, na którym w późniejszych etapach będzie prowadzona budowa linii. Natomiast drugim, niezbędnym elementem analizy jest długość planowanego tunelu, dlatego że nie przy użyciu każdej metody można wybudować dowolnej długości tunel.

Pierwsza metoda budowania linii średnicowej pod miastem Łódź jest tzw. metoda tradycyjna. Jej zasadnicza zaleta związana jest z tym, że może być ona zastosowana praktycznie w każdych warunkach. Charakteryzuje się drążeniem sztolni ${ }^{23}$ oraz szybkim wzmacnianiem powstałych ścian betonem. Budowa tunelu, w zależności od panujących

${ }^{23}$ Sztolnia (niem. Stollen) - podkop; podziemny wykuty w górotworze tunel, stanowiący przewód np. transportowy (Słownik wyrazów obcych, s. 836). 
warunków, może odbywać się także przy pomocy rak oraz z użyciem materiałów wybuchowych. W świecie techniki tradycyjna metoda budowy tuneli podziemnych określana jest jako "Neue Österreichische Tunnelbaumethode"24. Niestety, występuje kilka przeciwwskazań do zastosowania tej metody przy łódzkiej budowie. Tunele powstające w sposób tradycyjny są zdecydowanie bardziej wymagające finansowo. Niebezpieczeństwem jest również nieodpowiedni grunt (często dochodzi do osunięcia ziemi, co bezpośrednio wpływa na zagrożenie życia osób pracujących). Istnieja dodatkowe metody wspomagające budowę, np. zamrażanie gleby przed rozpoczęciem wydobywania, jednak wspomniany wyżej duży koszt ich zastosowania zmusił władze miasta do odstapienia od prowadzenia prac tą właśnie metodą.

Druga opcja, która posiada znacznie większa szansę powodzenia inwestycji, jest metoda drążenia tarcza, przy zastosowaniu urządzenia o nazwie TBM. TBM, z ang. Tunnel Boring Machine, oznacza maszynę do drażenia tunelu podziemnego. Obecnie system TBM jest najpopularniejszy, jeśli chodzi o wykonywanie konstrukcji tuneli średnicowych. Maszyna TBM składa się z trzech zasadniczych części:

- tarczy, która wcina się w grunt, powodując jego kruszenie i rozdrabnianie,

- instalacji transportującej rozdrobnioną ziemię w tył tunelu, w celu jej wydobycia na powierzchnię,

- urządzeń instalujących elementy nośne i konstrukcyjne linii średnicowej. W języku techniki nazywa się to "tubingami"25, które wykonane sa z betonu zbrojonego.

Aby maszyna TBM dostała się pod ziemię, najpierw należy metodą tradycyjną wykopać otwór wielkości ok. 20-25 m, aby móc bez problemów umieścić TBM wraz z tarczą drążąca. Co pewien czas należy jednak wymieniać tarczę w celu jej oczyszczenia i przystosowania do ponownego użycia. W związku z tym w określonym czasie powinno się zapewnić odgórny dostęp do budowanego w danej chwili odcinka.

Tacza wydobywająca ziemię może mieć różne wielkości. Z reguły tunele średnicowe budowane sa tak, aby po zakończeniu inwestycji zawierały po dwa albo jeden tor wewnątrz tunelu. Jednotorowe posiadają mniejszą średnicę niż dwutorowe. Ich wielkość wynosi odpowiednio 7,30-9,0 m dla tunelu jednotorowego, do $13 \mathrm{~m}$ w tunelu dwutorowym. Niekwestionowanym elementem bezpieczeństwa są chodniki ewakuacyjne, które muszą być zamontowane w tunelu. Tunele jednotorowe

${ }^{24}$ www.eos.ubc.ca/courses/eosc547/lecture-material/Rabcewicz-NATM.pdf [z dn. 11.10.2012].

25 J. Z. Mirski, Budownictwo z technologia, s. 57-67. 
posiadaja jeden chodnik, natomiast większa liczba torów wymusza na konstruktorach umocowania dwóch chodników ewakuacyjnych. Kolejnym elementem, który ściśle określaja procedury jest odległość od poszczególnych tuneli. Przyjmuje się, że ta odległość musi wynosić mniej więcej średnicę wybudowanych tuneli równoległych. Innym czynnikiem jest głębokość, która również jest ściśle ustalona przez normy techniczne. Minimalna głębokość tunelu, do którego wykonania używa się omawianej metody to 20-25 m, które oblicza się do główki położonej szyny. Jeżeli policzyć odległość od powierzchni ziemi do górnej granicy konstrukcji, to linie średnicowe oraz ich głębokość szacuje się w przedziale 12-17 m pod powierzchnia miasta. Normy bezpieczeństwa zalecaja budowanie tuneli równoległych, ponieważ ich późniejsze połączenie stanowi istotny element ewentualnych akcji ratunkowych. Gdy nastąpi awaria bądź kolizja pociągów, wtedy tunel równoległy do tego, w którym nastapiła awaria, stanowi tunel ewakuacyjny. W takim przypadku chodniki ewakuacyjne usytuowane sa co $500 \mathrm{~m}$. W innych przypadkach, gdy istnieje tylko jedna linia średnicowa, tunele rozlokowane sa co $1000 \mathrm{~m}$ oraz istnieje większe niebezpieczeństwo związane z akcja ratunkowa.

Biorąc pod uwagę wszystkie wady i zalety dwóch wyżej przedstawionych metod, Miasto Łódź zdecydowało się na wykorzystanie systemu TBM. Podstawowym wyznacznikiem w podejmowaniu decyzji był koszt prowadzonych robót, który zdecydowanie przemawia za metoda tarczy.

W momencie wyboru optymalnego dla miasta środka realizacji inwestycji pod względem budowlanym, pojawiła się kolejna kwestia, która musi być poddana dogłębnej analizie. Chodzi o lokalizację linii średnicowej oraz jej infrastruktury okalającej. Na tym etapie wyłonione zostały projekty przygotowane przez Centrum Naukowo-Techniczne Kolejnictwa, Urząd Miasta Łodzi oraz Stowarzyszenie Inżynierów i Techników Komunikacji RP. Podstawowym celem każdej jednostki była integracja Łodzi, jako centrum regionu, z krajowymi oraz międzynarodowymi sieciami kolejowymi, aby $\mathrm{w}$ Łodzi powstało dogodne miejsce pod ewentualne kolejne inwestycje. Dlatego też musiano przygotowywać opcje poszczególnych wariantów, mając na celu strategiczny charakter miasta na mapie geograficznej.

CNTK (Centrum Naukowo-Techniczne Kolejnictwa) przygotowało jeden wariant trasowania tunelu średnicowego pod miastem. Według niego tunel dworca Łódź Fabryczna biegnie wzdłuż ciągu ulic Narutowicza i Zielonej, odchodząc później na południe w kierunku ulicy 6 Sierpnia. Tam linia ma się rozdzielać na dwie odnogi. Jedną z nich stanowić będzie KDP, która będzie skierowana bezpośrednio na północ miasta. 
Kolejnym etapem miałby być nowy korytarz, który wyprowadzałby z miasta szybkie pociagi, jednak musiałby on być również wykonany od podstaw. $Z$ kolei pociaggi kierujące się na południowy zachód w kierunku Sieradza poruszałyby się po łącznicy, wybudowanej między linią średnicowa a dworcem Kaliskim. Oczywiście koniecznym rozgraniczeniem jest umieszczenie pociągów KDP oraz pociągów regionalnych i aglomeracyjnych na oddzielnych torach. I tak, wolne tory zlokalizowane byłyby na skrajnych torach w tunelu, natomiast KDP byłaby od strony wewnętrznej. Takie uwarunkowanie związane jest z planem przebudowy centralnego dworca $\mathrm{w}$ Łodzi, gdzie prestiżowa sprawa ma być podniesienie rangi dworca poprzez centralne umieszczenie i wyeksponowanie kolei dużych prędkości. Dodatkową sprawa jest ulokowanie przystanków dla kolei regionalnych. Pierwsza stacja mieściłaby się pomiędzy ulicami Kościuszki oraz Gdańska.. Wyjścia ze stacji możliwe byłyby też właśnie na te dwie ulice. Druga stacja ma się znajdować w sąsiedztwie placu Hallera, aby uatrakcyjnić ten region miasta, który ma potencjał komercyjny.

Nieco odmienna koncepcję budowy linii średnicowej ma Urząd Miasta Łodzi. Zakłada ona, iż powstaną dwa tunele równoległe. Jeden miałby obsługiwać wyłącznie koleje dużych prędkości, natomiast drugi - połączenia regionalne. Z założeń wynika, iż KDP zatrzymywać ma się w Łodzi tylko raz, na dworcu Łódź Fabryczna. Dlatego też podwarianty A i B projektu zakładaja przebieg KDP pod ulicami Narutowicza i Zielona, a następnie tunelem na południowy zachód pod dworcem Łódź Kaliska, aż z wyprowadzeniem niedaleko stacji Łódź Lublinek. Warianty A i B nie zakładaja również żadnych stacji dodatkowych na łódzkim odcinku szybkich kolei. $Z$ kolei wariant $C$ zakłada inny przebieg linii dużych prędkości, ponieważ prowadziłaby ona w sąsiedztwie Portu Lotniczego im. Władysława Reymonta. Tam ulokowany byłby przystanek dla korzystających z portu, a następnie linia kierowałaby się dalej na zachód w stronę Sieradza. Drugi tunel w swoim początkowym etapie miałby biec w sąsiedztwie tunelu KDP, jednak w okolicach placu Hallera rozgałęziałby się na dwie trasy. Jedna kierowałaby pociągi na północ w stronę Zgierza, a druga - Koleją Kaliską na południe w kierunku Sieradza. Podwarianty Urzędu Miasta zakładają także budowę łącznika pomiędzy lotniskiem a trasą kolei regionalnej (wariant A i B). Natomiast realizacja wariantu C, z koleja dużych prędkości bezpośrednio przebiegająca przy porcie lotniczym, powodowałaby, że nie byłoby konieczności budowy odcinka od Kolei Kaliskiej do lotniska. Podobnie, jak to miało miejsce w przypadku wariantu CNTK, Urząd Miasta Łodzi na trasie kolei regionalnej również widzi dwie stacje: jedna ulokowana 
przy ulicy Kościuszki, a druga na placu Hallera, gdzie rozgałęziać się będzie linia kolei regionalnej.

Zdanie prezentowane przez Stowarzyszenie Inżynierów i Techników Komunikacji RP (zwanego dalej SITK) jeszcze bardziej odbiega od koncepcji przedstawionej przez władze miasta oraz inżynierów kolejowych. Koncepcja SITK-u zakłada bowiem skrócenie tunelu średnicowego, skomasowanie linii KDP oraz regionalnych $w$ postaci jednego tunelu (a nie tuneli równoległych, jak w przypadku Urzędu Miasta) oraz utworzenie rozgałęzienia na kierunki zachód i południe w południowej części dworca Łódź Kaliska. Jednak w takiej sytuacji pojawiaja się dwa znaczące problemy dla trasowania tunelu. Pierwszym z nich jest problem inżynierski wyznaczenia odgałęzienia północnego na placu Hallera. Drugim mankamentem jest cały układ określany mianem "trójkąta linii kolejowych", czyli skrzyżowania szlaków północ-południezachód. Jest on związany z brakiem przestrzeni do wykonywania potrzebnych inwestycji. Podobnie jak w przypadku Urzędu Miasta, SITK wyznaczył trzy podwarianty wykonania inwestycji. Kwestia stacji dla kolei regionalnych (Łódź Centrum przy ulicy Kościuszki i plac Hallera) oraz usytuowania tunelu w początkowym biegu pozostała taka sama, jak w przypadkach omawianych przez CNTK i UMŁ. Również KDP utrzymuje swoje położenie jak w wariantach Urzędu (czyli trasa południowa). Zasadnicza zmiana jest rozgałęzienie usytuowane na południe od dworca Łódź Kaliska oraz odnoga północna tunelu, wyprowadzająca pociagi w kierunku Kutna. Najważniejszym jednak atutem wariantu przygotowanego przez SITK jest fakt, iż obniża on dość znacznie koszty budowy tunelu, ponieważ ogranicza jego długość.

Wszystkie wyżej wymienione warianty trasowania tunelu oraz jego infrastruktury poddane zostały analizie wielokryterialnej. Do badania użyto 15 cech, które uznano za decydujące przy wyborze optymalnego wariantu. Każdy wariant otrzymał ocenę od 2 do 5 za prezentowane przez siebie walory. Na podstawie tego została zsumowana ilość punktów, które otrzymały poszczególne rozwiązania.

Jak wynika z przedstawionej analizy, na wyróżnienie zasłużyły dwa projekty. Jeden, autorstwa CNTK oraz drugi, wykonany przez Urząd Miasta. Do ich głównych zalet należą: odpowiednia efektywność eksploatacyjna oraz duży stopień wykorzystania układu torowego, który jest obecnie dostępny na terenie miasta.

Jednym z głównych kryteriów wykonania inwestycji związanej z tunelem średnicowym jest szacowany koszt inwestycji. Dla oszacowania kosztu całkowitego wzorowano się na krajach (zwłaszcza Europy Zachodniej), w których technologia tuneli średnicowych jest sprawą powszechna. Jako przykład takiego kraju można uznać Hiszpanię, 
która posiada znaczny udział kolei dużych prędkości w swojej sieci oraz która wykorzystuje technikę linii średnicowych w miastach, aby rodzime linie kolejowe mogły bez problemów funkcjonować. Tabela 6 przedstawia szacowane koszty inwestycji z podziałem na: koszt całkowity, koszt budowy samego tunelu oraz koszty zwiazane z budowa infrastruktury pomocniczej (stacje kolei regionalnej). Oczywiście koszty zostały przedstawione dla każdego z wariantów trasy średnicowej.

Tabela 6. Koszty wykonania inwestycji w odniesieniu do poszczególnych wariantów budowy

\begin{tabular}{|l|r|r|r|r|r|r|r|}
\hline \multirow{2}{*}{ Wariant } & CNTK & UM Ł-a & UM Ł-b & UM Ł-c & SITK-a & SITK-b & SITK-c \\
\cline { 2 - 8 } & \multicolumn{7}{|c|}{ w mln zł } \\
\hline $\begin{array}{l}\text { Koszty całkowite } \\
\text { budowy }\end{array}$ & 1415 & 1718 & 1866 & 2008 & 1729 & 1807 & 1827 \\
\hline W tym tunel & 359 & 560 & 560 & 560 & 480 & 480 & 480 \\
\hline $\begin{array}{l}\text { W tym dwie stacje } \\
\text { pośrednie dla ruchu } \\
\text { regionalnego }\end{array}$ & 256 & 256 & 256 & 256 & 170 & 210 & 200 \\
\hline
\end{tabular}

Źródło: Stowarzyszenie Inżynierów i Techników Komunikacji RP, Analiza warunków budowy kolejowego tunelu średnicowego pod centrum Łodzi - podsumowanie i wnioski, Łódź 2008, s. 12.

Ogólnie można wywnioskować, że tunel nie stanowi większości wydatków w porównaniu z kosztem całkowitym. Należy jednak podkreślić, że jest to najważniejsza część inwestycji, bez której dalsze projekty (KDP) nie miałyby racji bytu. Po przeanalizowaniu kosztów uwidacznia się przewaga wariantu pierwszego nad resztą. Świadczy o tym wydatek całkowity rzędu 1,4 mld zł. Stanowi to minimum 300 mln oszczędność w stosunku do wariantów miasta oraz Stowarzyszenia Inżynierów i Techników Kolejnictwa RP.

Sprawą, która w czasach światowego kryzysu odgrywa najważniejszą rolę są pieniądze. Jak wspomniano wyżej, budowa samego tunelu na tle całej inwestycji nie jest bardzo kosztowna. Stanowi ok. 30\% wydatków na całą inwestycję. Należy jednak postawić istotne pytanie: skąd wziąć wymaganą sumę na pokrycie kosztów całego przedsięwzięcia? Jan Raczyński, opracowując analizę budowy linii średnicowej w Łodzi, wymienia kilka źródeł, z których mogą pochodzić pieniądze na budowę tunelu. Przede wszystkim takim źródłem jest Unia Europejska. $Z$ analizy budowy tunelu wynika, że jest ona w stanie pokryć ok. $68 \%$ kosztów. Pozostała część musi być przeznaczona z kapitału Polski. Zgodnie z ustawa, która weszła w życie 28 marca 2003 r. (a dokładnie - z rozdziałem 
7 tej ustawy, który dotyczy finansowania inwestycji związanych z transportem kolejowym), kolej oraz jej infrastruktura moga być finansowane z pieniędzy pochodzacych od:

- zarządcy infrastruktury, który przeznacza na inwestycję własny kapitał,

- budżetu państwa,

- władz samorządów terytorialnych,

- innych źródeł finansowania (kredyt z Europejskiego Banku Inwestycyjnego, emisja obligacji czy program partnerstwa publiczno-prywatnego).

Aby skutecznie zarządzać pozyskiwaniem środków na realizację budowy linii średnicowej pod centrum Łodzi, miasto powoła spółkę, której celem będzie koordynacja działań związanych z projektem. W pewnym sensie jej pierwszoplanowym celem jest pełnienie roli inwestora przy budowie. Do celów podległych celowi priorytetowemu należy chociażby wybór poszczególnych inwestorów, wykup gruntów itp.

Budowa linii średnicowej może być także traktowana jako część większego projektu. Mianowicie chodzi o projekt Nowego Centrum Łodzi, którego istotnym elementem jest tunel oraz reorganizacja komunikacyjnego węzła Łódź Fabryczna. W ten sposób powołana spółka zyskałaby dodatkowe fundusze od inwestorów realizujacych Nowe Centrum Łodzi.

\subsection{Znaczenie łódzkiego tunelu średnicowego dla rozwoju transportu kolejowego w Polsce - budowa kolei dużych prędkości}

Jak było wspomniane we wcześniejszych podrozdziałach, linia średnicowa nie ma na celu tylko i wyłącznie utworzenia połączenia łódzkich dworców w sposób bezkolizyjny, czyli pod ziemia. Idea jest znacznie szersza i sięga w przyszłość na około 10 lat, ponieważ właśnie w 2020 r. ma w pełnym wymiarze ruszyć kolej dużych prędkości, czyli połączenie szybką koleją największych ośrodków miejskich w Polsce ${ }^{26}$. Plany są takie, aby linia łączyła Warszawę z Poznaniem oraz Wrocławiem, a wszystkie połączenia przechodziły bezpośrednio przez Łódź, zatrzymując się na centralnym dworcu Łodzi, jakim bez watpienia byłby nowo powstały dworzec Łódź Centralna (możliwe jest również, że dworzec utrzyma nazwę, która obowiązywała do tej pory). Widoczna jest gołym okiem istotna rola Łodzi w sukcesie całego przedsięwzięcia.

${ }^{26}$ S. M. Koziarski, Sieć kolejowa Polski w latach 1918-1992, Instytut Śląski, Opole 1993, s. 191. 
W 2006 r. powstał dokument zatytułowany Studium przebiegu przez Łódź Kolei Dużych Prędkości V-300, określający główne założenia miasta $\mathrm{w}$ kontekście realizowania projektu kolei. Podobnie, jak miało to miejsce przy lokalizacji tunelu i rozwiązaniach komunikacyjnych, tak również przy realizacji KDP bierze się pod uwagę 7 wariantów przebiegu. Dotyczą one m.in.: przebiegu linii kolejowej pomiędzy aglomeracjami, opcji ulokowania w odpowiednich aglomeracjach oraz planów budowy nowych lub remontowania starych odcinków torowych.

Warianty od 1 do 4 zakładaja prawie w całości budowę nowej linii kolejowej, na której miałby odbywać się ruch kolei dużych prędkości. Natomiast warianty 5, 6 i 7 przewidują modernizację już istniejących odcinków oraz wprowadzenie ruchu pociągów szybkich. Niestety, ich prędkości na wyremontowanych odcinkach nie wiązałyby się $z$ tymi, jakie przedstawiono w założeniach studium wykonalności KDP. Zakłada ono powiem, że prędkość minimalna na trasie kolei dużych prędkości będzie wynosiła $300 \mathrm{~km} / \mathrm{h}$. Renowacja istniejącego układu torowego jest w stanie zagwarantować prędkości na trasach (z wykluczeniem miast, w których prędkości maksymalne są znacznie niższe) do ok. $200 \mathrm{~km} / \mathrm{h}$.

Aby w 100\% zaktywizować działalność ośrodków aglomeracyjnych, jednocześnie podwyższając ich atrakcyjność oraz ekonomiczność, wszystkie strony biorace udział w projekcie opowiedziały się za wybraniem wariantu 1 jako wiążącego, gdzie opcją w jednym z punktów jest przejście linii przed centrum Łodzi. Zakłada on, że:

- kolej dużych prędkości będzie miała parametry o wysokich prędkościach na całej trasie, wykluczając tylko miejsca węzłowe (czyli miasta, przez które będzie przebiegać i w których będzie miała swoje przystanki),

- Kolejowy Węzeł Warszawski będzie miał 3 podwarianty wejścia linii (obecnie brak danych o tych wprowadzeniach),

- szybka linia, łącząc stolicę z Łodzia, przebiegać będzie wzdłuż autostrady A2,

- trasa kolei dużych prędkości pod centrum Łodzi przebiegać będzie nowym tunelem średnicowym,

- trasa na zachód od Łodzi ulokowana będzie na północ od zalewu Jeziorsko, a swoje rozgałęzienie na odcinki do Wrocławia i Poznania będzie mieć w Kaliszu,

- wprowadzenie linii do odpowiednich węzłów komunikacyjnych w Poznaniu i Wrocławiu będa wyznaczone w planach podobnych do studium, a przygotowanych przez jednostki administracyjne stolic Wielkopolski i Dolnego Śląska. 
Tunel średnicowy, a także kolej dużych prędkości mają w swoich założeniach „wpuszczenie” dworca Łódź Fabryczna pod ziemię. Jego modernizacja ma tworzyć nowy węzeł komunikacyjny, w którym ulokowane byłyby zarówno połączenia kolejowe (na poziomie międzynarodowym, międzyregionalnym i regionalnym), jak i autobusowe (obsługujące ruch międzymiastowy i międzynarodowy dla linii PKS oraz stację końcową dla autobusów Miejskiego Przedsiębiorstwa Komunikacji). Modernizacja dworca rozpoczęła się w połowie 2010 r. i ma trwać do roku 2014. Ciekawostką jest to, iż od lipca 2009 r. trwało "wielkie odliczanie" prowadzone na szybach pociągów relacji Łódź-Warszawa. Pociągi odliczały okrągły rok, aż do lipca 2010, kiedy to rozpoczęła się wielka budowa w rejonie Łodzi Fabrycznej. Na czas budowy funkcję głównego dworca miasta przejęła stacja Łódź Widzew.

Budowa kolei dużych prędkości, która jest rozpisana na 10 lat, składa się z kilku etapów przygotowań:

- etap I - remont dworca Łódź Fabryczna (lata 2012-2015),

- etap II - budowa łódzkiego tunelu średnicowego oraz przystosowanie węzłów komunikacyjnych pozostałych miast do przyjęcia pociągów dużych prędkości (2015-2017),

- etap III - budowa nowych odcinków KDP, łączących poszczególne miasta (2016-2020),

- etap IV - testowanie systemu kolei dużych prędkości (2016-2020),

- etap V - uruchomienie pierwszej w Polsce kolei dużych prędkości V-300 - rok 2020.

W charakteryzacji wymienionych wyżej etapów wyróżnia się pewna niezgodność. Mianowicie, zakończenie budowy nowych odcinków planowane jest na rok 2018, natomiast pierwsze testy KDP zaplanowane sa w 2016 r. Dzieje się tak dlatego, że najszybciej powstanie linia łącząca Łódź z Warszawa. Jest to związane z mniejszą odległością dzieląca dwa miasta (długość linii to około 130 km, a trasa z Łodzi do Poznania i Wrocławia jest prawie 2 razy dłuższa). Jednak plan Ministerstwa Infrastruktury zakłada, że linia "Y" ruszy w tym samym momencie, czyli w roku $2020^{27}$.

\section{Podsumowanie}

W wyniku analiz przeprowadzonych w niniejszym rozdziale sformułowano następujące wnioski:

${ }^{27}$ F. Nietz, W 35 minut do Łodzi, "Gazeta Transportowa" 2009, nr 49 (863), grudzień, s. 1. 
- Polski rynek kolejowy nie może być nazywany monopolistycznym, ponieważ pomimo znacznego (prawie 95\%) udziału spółki PKP PLK S.A. na rynku istnieją inne linie - głównie prywatne, które wykorzystywane są do świadczenia przewozów.

- Transport kolejowy zyskuje na znaczeniu w większych miastach, które nękane sa problemem nadmiernego ruchu samochodowego. $Z$ tego względu powstaja obiekty nazywane tunelami średnicowymi, przeprowadzające pod miastem linie kolejowe, po których poruszają się zarówno składy międzyregionalne, jak i miejskie. Ma to na celu przekonanie mieszkańców poszczególnych regionów do rezygnacji z użytkowania samochodów na rzecz konkurencyjnego transportu kolejowego.

- W Europie można podać wiele przykładów miast, w których technologia tunelu średnicowego znalazła zastosowanie. Sa to np. Berlin, Rotterdam, Bruksela i Warszawa. Już w niedalekiej przyszłości zobaczymy podobne budowle podziemne w Lipsku i Łodzi. Analizy przeprowadzone przez Miasto Lipsk stanowiły podstawę przystapienia do realizacji inwestycji, ponieważ ukazywały znaczny wzrost efektywności transportu kolejowego. Tunel był budowany przy pomocy technologii określanej jako Nowa Austriacka Metoda Budowy Tuneli.

- Można powiedzieć, że łódzki tunel jest bardzo podobny do tego, którzy buduja sąsiedzi za Odra. Powstaje on przy zastosowaniu tej samej metody.

- Po dokonaniu wielu wszechstronnych analiz i zasięgnięciu rady przez specjalistów od urbanistyki oraz zagospodarowania przestrzennego miasta można wywnioskować, że spośród siedmiu wariantów trasowania tunelu tylko dwa są w stanie liczyć się w kontekście końcowej realizacji (która planowana jest po ukończeniu modernizacji i „wpuszczania" pod ziemię dworca kolejowego Łódź Fabryczna). Sa to warianty przygotowane przez Centrum Naukowo-Techniczne Kolejnictwa oraz Urząd Miasta Łodzi.

- W dłuższej perspektywie (sięgającej nawet roku 2020) Łódź ma stanowić swoiste centrum infrastrukturalne. Powstać ma tzw. ring, który składać się będzie z autostrad A1 i A2 oraz dróg ekspresowych S8 oraz S14. Doliczając do tego kolej dużych prędkości, biegnąca z Warszawy do Poznania i Wrocławia (z wykorzystaniem tunelu średnicowego pod centrum miasta), Łódź stanie się prawdziwym rajem dla firm z sektora Transport - Spedycja - Logistyka. Doskonała dostępność różnych rodzajów transportu może być czynnikiem przyciągającym inwestorów. 
- Budowa trasy średnicowej może także spowodować integrację wewnątrz regionu łódzkiego, gdyż utworzona zostałaby także kolej aglomeracyjna, która ułatwiłaby dostęp do miasta ludności mieszkającej poza jego granicami.

- Transport w Niemczech należy do jednych z najlepszych i najlepiej zorganizowanych na świecie, dlatego też Łódź, wzorując się na Lipsku, może mieć pewność, że rezultat widziany po okresie realizacji nie zostanie oceniony negatywnie. 



\section{Rozwój multimodalnego węzła Łódź Olechów}

Katarzyna Raj*

\subsection{Wybrane inwestycje drogowe w województwie łódzkim}

Województwo łódzkie ze względu na swoje położenie w centrum Polski, ale także Europy, ma wiele możliwości rozwoju. Jednak urzeczywistnią się one tylko dzięki odpowiednim wspólnym działaniom samorząów oraz wytrwałości w założonych celach. Władze dażą do polepszenia statusu majątkowego mieszkańców. Chca także zmniejszyć bariery komunikacyjne poprzez rozbudowanie sieci dróg i autostrad. W ten sposób województwo może się stać bardziej dostępne dla przedsiębiorców, co w dalszej kolejności spowoduje utworzenie nowych miejsc pracy i zmniejszenie bezrobocia. W regionie powstaje coraz więcej centrów logistycznych i firm specjalizujących się w konkretnej dziedzinie: przemysł farmaceutyczny, produkcja sprzętu AGD, materiałów budowlanych. Do kolejnych działań umożliwiających rozwój regionu zaliczyć należy przekształcenie transportu drogowego, kolejowego, lotniczego np. poprzez zastosowanie nowoczesnych rozwiązań technologii informatycznej. Wszelkie zmiany powinny być wprowadzane z uwzględnieniem jak najmniejszej ingerencji w środowisko. Ponieważ miasto Łódź nie korzysta w pełni ze swojego strategicznego położenia, budowany jest centralny węzeł komunikacyjny wokół Łodzi, który ma się składać z autostrad A1 i A2, dróg ekspresowych S8, S14, S74. Jego elementem ma być również szybka kolej, łącząca Łódź z Warszawą i Wrocławiem. Węzeł zawierał będzie także port lotniczy pomiędzy Łodzią a Warszawa. W jego ramach planowane jest przekształcenie portu Łódź Lublinek i lotniska cargo w Łasku.

Za stan nawierzchni i rozwój sieci drogowej w województwie łódzkim odpowiada Generalna Dyrekcja Dróg Krajowych i Autostrad z oddziałem w Łodzi oraz Zarząd Dróg i Transportu. Do głównych zadań wykonywanych przez ZDiT należy gospodarowanie drogami publicznymi. Zarząd jest również odpowiedzialny za kierowanie ruchem na tych jezdniach zgodnie $\mathrm{z}$ prawem o ruchu drogowym, zajmowanie się

* Mgr Katarzyna Raj - Katedra Logistyki, Wydział Zarządzania Uniwersytetu Łódzkiego, ul. Matejki 22/26, 90-237 Łódź. 
komunikacja miejska, wystawianie licencji lub zezwoleń na realizację przewozu krajowego osób lub rzeczy zgodnie z ustawa o transporcie drogowym, z wyłączeniem przewozów taksówkowych ${ }^{1}$. Natomiast do zadań GDDKiA należy monitorowanie prac na drogach krajowych, sprawdzanie jakości nawierzchni na tych drogach, a także kierowanie i zajmowanie się ruchem na drogach krajowych. Dyrekcja odpowiada też za bezpieczeństwo i oddziaływanie tych tras na środowisko. Aby móc w pełni wykonywać swoje zadania, GDDKiA musi kontaktować się z samorządem województwa łódzkiego. Wspólnie realizują plany rozwoju infrastruktury drogowej $w$ tym regionie².

Aktualnie wiele inwestycji realizowanych jest dzięki środkom finansowym z Unii Europejskiej. Zgodnie z Programem Operacyjnym Infrastruktura i Środowisko na lata 2010-2015, w regionie łódzkim zamierza się wykonać wiele prac. Jednym z takich przedsięwzięć jest otworzenie kolejnego odcinka autostrady A1 między węzłem Kowal a węzłem Stryków I. Do kolejnych działań należy zaliczyć powstanie odcinka drogi ekspresowej S8 między węzłem Walichnowy a Łodzią ${ }^{3}$, ale również przebudowanie drogi krajowej $\mathrm{nr} 8 \mathrm{w}$ drogę ekspresową S8 w części pomiędzy Piotrkowem Trybunalskim a granicą województwa mazowieckiego. Według tego programu planowane jest przekształcenie drogi krajowej nr 12/74 na odpowiadająca standardom drogi ekspresowej. Został także opracowany plan stworzenia S14 na odcinku łączącym zachodnia obwodnicę Łodzi ze Zgierzem i Pabianicami. W ramach programu będą realizowane projekty obwodnic dla miast - Wielunia, Bełchatowa, Opoczna, Pabianic, Inowłodza, Poświętnego, Brzezin. Zaprojektowano wzmocnienie i rozbudowę dróg krajowych (DK $\mathrm{nr} 1,8$, $12,14,45,48,71,72,74,83,91)$ w różnych odcinkach.

W lipcu 2007 r. powstał Regionalny Program Operacyjny Województwa Łódzkiego na lata 2007-2013. Jego celem jest poprawa wizerunku województwa łódzkiego, zwiększenie jego konkurencyjności gospodarczej, zmniejszenie barier z różnymi regionami należącymi do państw Unii Europejskiej. Program ma być współfinansowany m.in. z Europejskiego Funduszu Rozwoju Regionalnego. Zgodnie z RPO, województwo łódzkie nie potrafi w pełnym zakresie wykorzystać przechodzących przez nasz region dwóch korytarzy transportowych, które łączą centrum Polski z cała Europa. Wśród 10 korytarzy przebiegających przez

\footnotetext{
${ }^{1}$ www.zdit.uml.lodz.pl/index.php?str=107 [z dn. 20.11.2011].

2 www.gddkia.gov.pl/article/oddzialy/gddkia_lodz/inwestycje_i_remonty//index. php?id_item_tree=85ac3d0e168cca98f3ed7f18ba2a102b [z dn. 21.04.2010].

${ }^{3}$ Dnia 24 sierpnia 2011 r. z udziałem ówczesnego ministra infrastruktury C. Grabarczyka rozpoczęła się budowa węzła Walichnowy.
} 
nasz kontynent, w województwie łódzkim można wyróżnić II korytarz (Berlin-Warszawa-Moskwa-Niżnyj Nowgorad) i VI korytarz (GdańskKatowice-Żilina). Według danych Zarządu Dróg i Transportu, drogi w województwie łódzkim uważane są za jedne z gorszych w Polsce. Dlatego należy zadbać o jak najszybszą przebudowę nawierzchni. Kolejnym problem jest brak obwodnic wielu miast. Regionalny Program Operacyjny Województwa Łódzkiego zawiera wiele priorytetów. Wśród nich są także zmiany w infrastrukturze transportu.

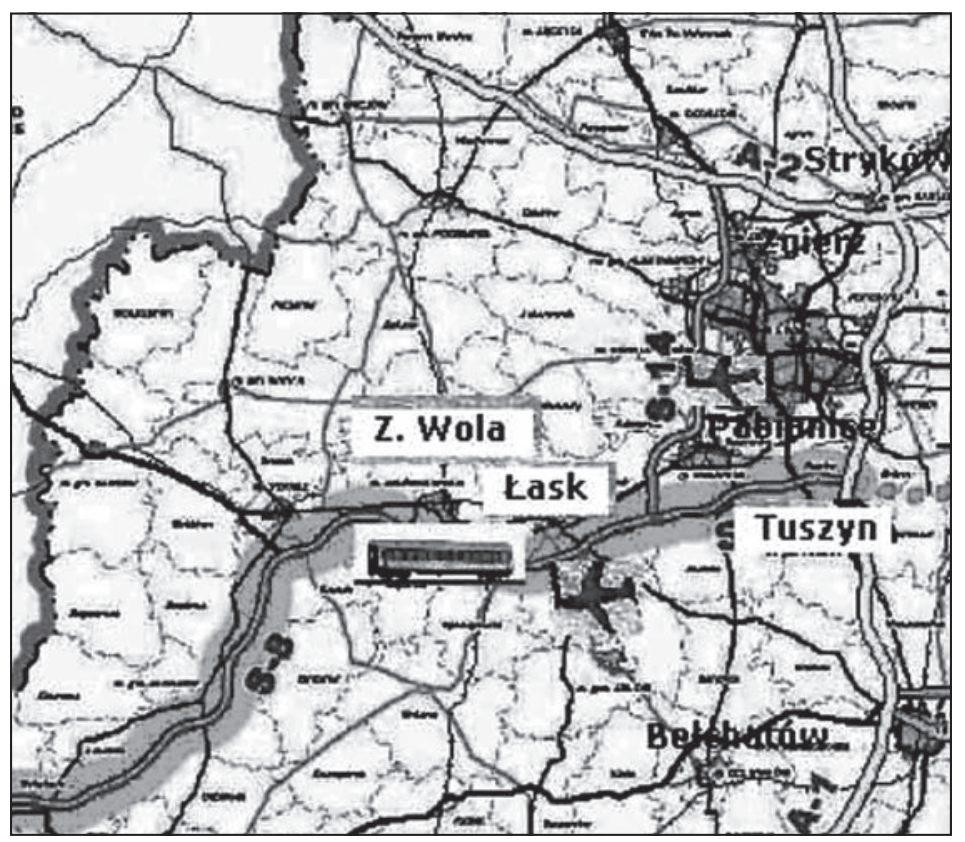

Rysunek 11. Planowany przebieg trasy S8 w rejonie Zduńskiej Woli

Źródło: R. Kozłowski, Szanse i zagrożenia dla rozwoju przedsiębiorstw w regionie łódzkim związane z infrastrukturą makrologistyczna, [w:] S. Lachiewicz, I. Staniec (red.), Sytuacja ekonomiczna, organizacyjna $i$ kadrowa dużych organizacji gospodarczych w aglomeracji łódzkiej, Wyd. Media Press, Łódź 2007, s. 41

Droga, która budzi najwięcej kontrowersji w województwie łódzkim jest droga ekspresowa S8. Pierwsze plany przebiegu tej drogi odnaleźć można już w 1938 r. Miała ona połączyć Wrocław z Łodzią i Kaliszem. W kolejnych latach różnie zmieniały się plany S8. W 1993 r. zgodnie z rozporządzeniem Rady Ministrów opracowano projekt, w którym droga ekspresowa S8 miałaby się przekształcić w autostradę A8. Następnie w 2000 r. powrócono do planów drogi ekspresowej, jednak zmieniono już jej trasę. Według projektu miała przechodzić przez Piotrków Trybunalski 
oraz Bełchatów, pomijajac Łódź. Wywołało to pewne kontrowersje wśród władz wojewódzkich i samorządowych. Innego układu drogi chce GDDKiA, a innego Biuro Projektowania Przestrzennego Województwa Łódzkiego. Więcej powodów do wybudowania drogi ekspresowej w wariancie północnym (Wrocław, Sieradz, Zduńska Wola, Łask, Pabianice, Łódź) przemawia za BPPWŁ. W przypadku wyboru wariantu południowego (Wrocław, Syców, Kępno, Wieluń, Bełchatów, Piotrków Trybunalski, Warszawa) wiele regionów nie miałoby szans rozwoju. Dzięki pierwszemu wariantowi węzeł łódzki mógłby konkurować z tzw. pierścieniem berlińskim, wybudowanym wokół dróg i autostrad w obrębie Berlina. S8 ma za cel połączenie części centralnej z południem kraju i autostradą A1. Jej trasa ma się nieznacznie różnić od obecnej drogi krajowej nr 8. Wzdłuż tej trasy maja powstać wiadukty, mosty, przejścia dla ludzi i zwierząt.

Kolejną ważną droga ekspresowa, która odgrywa dużą rolę w województwie łódzkim jest S14. W 1997 r. w Studium Zagospodarowania Przestrzennego Województwa Łódzkiego pojawiła się pierwsza informacja o S14. Jej głównymi atutami jest odciążenie Zgierza od ruchu tranzytowego poprzez wybudowanie obwodnicy. Podobna sytuacja ma miejsce w Pabianicach, gdzie ruch w momencie wybudowania obwodnicy zostałby znacznie ograniczony. Droga ekspresowa uważana jest przez wielu za obwodnicę Łodzi (odciąży aleję Włókniarzy), jednak będzie posiadała także inne funkcje. Może zwiększyć tranzyt pomiędzy regionami - Łęczyca (na północy), Łaskiem, Zduńską Wolą (południowy zachód). S14 ma za cel połączyć autostradę A1 (węzeł Emilia) z droga ekspresowa S8 (węzeł Róża). Według planów ma przebiegać przez gminy: Zgierz, Aleksandrów Łódzki, Konstantynów, Pabianice. Według planów GDDKiA, zawartych w "Kompleksach funkcjonalno-realizacyjnych S-14" budowę drogi podzielono na cztery części. Pierwsza faza została zaprojektowana od węzła Łódź-Południe do węzła Pabianice-Dobroń. Ma zostać wybudowana w ramach obwodnicy Pabianic. Przetarg na ten odcinek ogłoszono 12 czerwca 2009 r. Rozstrzygnięcie nastapiło w 2012 r. Drugie stadium zaplanowano od węzła Emilia do Łodzi (węzeł alei Włókniarzy), kolejny od węzła ŁódźPółnoc do węzła Łódź-Południe (przez Aleksandrów i Konstantynów). Ostatni z zaplanowanych etapów będzie przebiegał od węzła PabianiceDobroń do rejonu Łask-Lotnisko. Ma zostać zrealizowany zgodnie z budową drogi ekspresowej S8. 8 stycznia 2010 r. opublikowano decyzje o uwarunkowaniach środowiskowych. Jednak w momencie zatwierdzenia południowego wariantu drogi ekspresowej S8 nie powstanie S14.

Następna $z$ inwestycji planowanych $w$ województwie tódzkim jest budowa autostrady A1. Należy ona do VI korytarza transeuropejskiego. Przebiegać ma przez następujące gminy: Łanięta, Gostynin, Strzelce, Kutno, Oporów, Krzyżanów i Piątek, Bielawy, Tuszyn, Moszczenica, 
Czarnocin, Grabica, Wola Krzysztoporska, Rozprza, Kamieńsk, Gomunice, Dobryszyce, Ładzice, Radomsko, Głowno, Stryków, Nowosolna, Andrespol oraz miasta: Łódź, Brójce i Rzgów4 21 kwietnia 2010 r. GDDKiA podała do publicznej wiadomości, że poszukuje projektanta i wykonawcy na stworzenie autostrady między Strykowem a węzłem Tuszyn. Nawierzchnia tej drogi będzie wykonana w technologii betonowej. Część tej trasy zawiera $40 \mathrm{~km}$ jezdni. Podpisanie umowy przewiduje się na poczatek 2011 r. Od tego momentu wybrany wykonawca ma 32 miesiące na wykonanie inwestycji. Zgodnie z tymi zamierzeniami ukończenie tego odcinka ma nastapić w II, III kwartale $2013 \mathrm{r}^{5}$

Kolejna inwestycja rozpoczęta $w$ województwie łódzkim jest budowa autostrady A2. Jej zadaniem ma być połaczenie wschodu z zachodem Europy. Obecnie istnieje już odcinek pomiędzy węzłem Modła a węzłem Stryków II. Ma on długość ok. 104 km. We wrześniu 2009 r. została podpisana kolejna umowa na wybudowanie odcinka pomiędzy Strykowem a Konopką. Przetarg wygrało pięć różnych firm, które zobowiązały się do ukończenia tego odcinka w maju 2012 r., tak aby był gotowy na Mistrzostwa Europy organizowane przez Polskę i Ukrainę w 2012 r. Odcinek ten ma długość 91 km.

Skrzyżowanie dwóch największych autostrad (A1 i A2) leży w obrębie województwa łódzkiego. Dlatego tak ważne jest, aby każda z tych inwestycji została wykonana w terminie. Dnia 23 czerwca 2010 r. przy udziale ministra C. Grabarczyka rozpoczęto budowę węzła autostradowego w Strykowie. W rejonie Strykowa (miejsce skrzyżowania się autostrad) powstaje coraz więcej miejsc pracy. Właśnie ten teren wybieraja inwestorzy. W ten sposób województwo łódzkie staje się bardziej konkurencyjne wśród innych regionów i ma możliwość rozwoju gospodarczego.

\subsection{Infrastruktura kolejowa i jej przyszłość w regionie łódzkim}

Łódź swoje starania o kolej rozpoczęła w 1857 r., a już w roku 1866 połączono Łódź z linią Warszawsko-Wiedeńską w Koluszkach ${ }^{6}$. W 1886 r. W "Tygodniku Ilustrowanym" historyk i publicysta Oscar Flatt przedstawił Łódź: „[...] W 1820 roku zaliczona została Łódź do rzędu miast

\footnotetext{
${ }^{4}$ www.lodzkie.eu/index.php3?str=159 [z dn. 21.11.2011].

${ }^{5}$ www.poznan.gddkia.gov.pl/article/informacje/aktualnosci/article.php/id_ item_tree/f45b707512615a0425765e080daea184/id_art/3adb5e629e52576ed79e95a065efa84e [z dn. 21.04.2010].

${ }^{6}$ Z. Taylor, Regres i rozwój sieci kolei w Polsce, PAN Instytut Geografii i Przestrzennego zagospodarowania, Warszawa 2007, s. 26.
} 
fabrycznych [...]. W epoce tej rozwijał się w Łodzi jednocześnie przemysł sukienniczy, Iniany i bawełniany [...]. Dziś Łódź pewniejszym idzie krokiem po drodze fabrycznego postępu [...]. Jednym z ważniejszych warunków powodzenia dla każdej miejscowości fabrycznej są dogodne środki komunikacyjne. Więc też prawie jednocześnie z założeniem tutejszej osady fabrycznej, weszła w linię traktu fabryczno-kaliskiego; potem połączyła się bita droga ze Zgierzem, Łęczyca, Krośniewicami na górnym trakcie łowicko-kaliskim; po przeprowadzeniu zaś drogi żelaznej Warszawsko-Wiedeńskiej, urządziła trakt bity do stacji Rokocin. Wkrótce jednak wszystkie te środki komunikacyjne okazały się niedostatecznymi dla dowozu surowych materiałów i zbytu miejscowej produkcji. Łódź żywo uczuła konieczność bezpośredniego zetknięcia się z europejską siecia dróg żelaznych [...]"77.

W tamtych czasach obecna Polska była podzielona między carską Rosję, Prusy i Austro-Węgry. Władza w Królestwie Polskim należała do Rosjan, co utrudniało realizowanie wielu przedsięwzięć. Już w tym czasie Łódź, jako bogate miasto przemysłowe, była atrakcyjnym celem dla linii kolejowej, dlatego też mieszkańcy bardzo zabiegali o jej wybudowanie. Zależało na tym głównie kupcom i fabrykantom, gdyż powstanie nowej linii umożliwiłoby ich dalszy rozwój. Gdy budowano Kolej Warszawsko-Wiedeńską, wydawało się, że Łódź na pewno będzie miastem posiadającym kolej - jednak tak się nie stało. Wybrano małe miasta, które były miejscami wypoczynku władz, zamiast prężnie rozwijającej się Łodzi. Jednym z powodów takiej decyzji mogła być obawa władz przed zbyt szybkim wzrostem ekonomicznym miasta i zbyt dużą populacja Żydów. Linia Warszawsko-Wiedeńska, otwarta w 1847 r., omijała Łódź z daleka. Obsługę miasta przewidziano za pomoca drogi poprowadzonej od stacji Rokiciny. Po utracie tego połączenia zaczęto się starać o pozwolenie na budowę linii Rokiciny-Łódź-Kalisz, jednak starania te spełzły na niczym. W Łodzi krzyżowały się drogi łączące ośrodki przemysłowe i stary trakt handlowy do Piotrkowa i Krakowa. Ówczesny układ dróg kształtował sieć kolejową w okręgu łódzkim. Łódzcy fabrykanci kontynuowali walkę o połączenie kolejowe z Koleja Warszawsko-Wiedeńską w Rokicinach w 1861 r. Jednak i te starania się nie powiodły. Powodem odrzucenia projektów przeprowadzenia kolei przez Łódź była doktryna wojenna rosyjskiego sztabu generalnego. Władze rosyjskie uważały, że brak linii kolejowych w zachodnich guberniach będzie stanowił ochronę przed atakiem Prus. Kolejnym problemem były zbyt słabe związki łódzkich i kaliskich przedsiębiorców z urzędnikami rosyjskimi w Warszawie

${ }^{7}$ M. Jerczyński, T. Roszek, Szlakiem łódzkiej kolei, Łódź 2003, s. 58. 
i Petersburgu. Dopiero w 1864 r. udało się uzyskać zgodę na wykonanie badań technicznych i terenowych połączenia Łodzi z Koleją Warszawsko-Wiedeńska i przedłużenie jej do Kalisza8. Po zapoznaniu się z wynikami badań władze rosyjskie zgodziły się na połączenie Łodzi z Warszawa droga kolejowa. Po tej decyzji łódzcy przemysłowcy utworzyli Towarzystwo Łódzko-Fabrycznej Drogi Żelaznej. „Akt notarialny został spisany w Warszawie, przed notariuszem Władysławem Więckowskim 14/26 sierpnia 1865 r. (nr aktu 786). Siedzibą towarzystwa była Warszawa"9.

Członkami towarzystwa byli handlowcy, fabrykanci, przemysłowcy. Założyciele podzielili akcje między siebie. Resztę postanowili sprzedać na wolnym rynku. Władze rosyjskie nie mogły wykupić linii przed upływem 12 lat od jej uruchomienia. Towarzystwo było zwolnione od wszystkich podatków poza podatkiem od nieruchomości, płaconym w całym Królestwie Polskim. Jednocześnie mieli obowiazek bezpłatnie przewozić materiały poczty i urzędników pocztowych. Budowę kolei w Łodzi rozpoczęto 28 lipca 1865 r. "Trasę wytyczono przez wieś Żakowice, Kolonie Borowo, wieś Gałkowa, kolonię Janków i Justynów, wieś Bedoń. Za Andrespolem, w kolonii Andrzejów planowano przystanek. Dalej szlak przebiegał przez Wiączyn, Ner, Janów, Henryków, Antoniew, przez widzewski lasek do Łodzi"10. Linia kolejowa składała się z jednego toru. Choć plany zakładały linię dwutorowa, ze względu na oszczędności zarząd kolei zdecydował się na pierwszy wariant. Osoby budujace dworzec w Łodzi chcieli umiejscowić go na wschód od miasta. Jednym z powodów takiego wyboru były względy ekonomiczne (nie musiano przeprowadzać linii przez miasto). Przedsiębiorcy mieliby bliżej z przewozem swoich towarów. Ostatecznie zdecydowano się na jego lokalizację jak najbliżej ulicy Piotrkowskiej, w miejscu, gdzie się obecnie znajduje, czyli przy ulicy Fabrycznej (dawniej ulica Dzika).

26 listopada 1889 r. odbyło się spotkanie generalnego gubernatora warszawskiego z prezydentem Łodzi, łódzkimi fabrykantami i inspektorem dróg żelaznych. Rozmawiano o budowie kolei obwodowej dla Łodzi. Projekt miał zaczynać się od stacji Widzew przez Stoki, Marysin, Stare Bałuty do Radogoszczy. Z obwodnica miało się łączyć 40 bocznic fabrycznych. Planowano także rozbudowę kolei z Chojen do Pabianic. Stacja Widzew maiła być miejscem rozładunku lub rozprowadzania towarów do konkretnych fabryk. Według władz rosyjskich

\footnotetext{
8 Tamże, s. 58-60.

9 Tamże.

10 Tamże, s. 60.
} 
obwodnica kolejowa nie miała racji bytu. Obawiano się, że przez taką budowę obniża się koszty towarów łódzkich przedsiębiorców oraz zwiększy się ich horyzont terytorialny. Decyzja generał-gubernatora warszawskiego o wstrzymaniu obwodnicy dla Łodzi była korzystna dla członków Towarzystwa Drogi Żelaznej Fabryczno-Łódzkiej. Mieli oni nadal monopol na usługi kolejowe dla Łodzi, ale także dla pobliskich miejscowości. Ministerstwo Komunikacji z powodu licznych protestów nakazało Towarzystwu Drogi Żelaznej Fabryczno-Łódzkiej wybudowanie na stacji Widzew stacji dla segregacji wagonów przyjeżdżających do Łodzi.

Stacja Łódź Widzew począwszy od pierwszych planów miała za zadanie być stacją towarowa. Dzięki temu skracała drogę KoluszkiKutno, omijając jednotorowe odcinki Skierniewice-Łowicz i ŁowiczKutno. Postanowiono wówczas rozbudować układ torowy, dając lepsze możliwości dla sortowni wagonów. Nie wybudowano żadnych atrakcyjnych budynków wokół stacji. Podczas I wojny światowej stacja Łódź Widzew rozbudowywała się m.in. z linia do Zgierza. W latach 1926-1929 myślano nad planem regulacyjnym. Prace postanowiono powierzyć dr. inż. Christophowi Rancke (były główny inżynier Wydziału Budowlanego Magistratu Miasta Łódź). Dzięki temu planowi władze municypalne chciały polepszyć wizerunek przestrzenny i strukturę miasta. Postanowiono w nim zwiększyć nacisk na kolej obwodową oraz linię Widzew-Zgierz. Wnioskowano o zwiększenie bocznic na stacji Chojny oraz obwodnic nowych stacji i posterunków bocznicowych. Chciano w ten sposób zmniejszyć ruch na innych stacjach towarowych, m.in. Łódź Kaliska, Karolew, Łódź Fabryczna. Myślano również o wybudowaniu drugiego dworca towarowego na Radogoszczy, który miałby za zadanie przeładunek artykułów spożywczych i masowych. Rancke widział ówczesny stan łódzkiej kolei i dlatego dażył do takiej modernizacji. Ze względu na swoje pochodzenie i działalność w okresie I wojny światowej, spotkał się z niechęcia łódzkich fabrykantów. Po wkroczeniu Niemiec na polskie ziemie łódzki węzeł kolejowy podporzadkowano niedawno powstałej Dyrekcji Kolei w Poznaniu (od 1 listopada 1939 r. Dyrekcja Kolei Rzeszy). W 1939 r. Niemcy postanowili włączyć węzeł łódzki do programu modernizacji kolei zachód-wschód ze względu na zwiększone potrzeby transportowe. Postanowiono wybudować w Łodzi nową stację rozrządowa z parowozownią (zgodnie przedwojennymi planami). W marcu 1940 r. zaczęto wysiedlać mieszkańców wsi Olechów, Feliksin, Jędrzejów, Augustów pod budowę nowej stacji. Prace rozpoczęto we wrześniu 1940 r. od zrobienia nasypu oraz wyrównania terenu. Największy postęp prac przypadł na lata 1942-1943, czego skutkiem był wyzysk robotników przymusowych. Po raz pierwszy 
olechowska parowozownia rozpoczęła pracę w listopadzie 1942 r. „Do jej obsługi wzniesiono monumentalną wieżę ciśnień z zespołem studni głębinowych rozmieszczonych w okolicznych lasach, oczyszczalnię ścieków, kotłownię, zespoły magazynów i odlewnię żeliwa"11. Do sierpnia 1944 r. stacje posiadały zdolność przerobowa 1600 wagonów na dobę, gdy w 1940 r. według Niemców zdolność ta wynosiła 1200 wagonów na dobę.

Dzięki rozbudowie stacji Olechów zyskały inne stacje węzła i przyległe linie. W latach 1940-1941 rozpoczęto na stacji Widzew budowę stacji rozrzadowej poprzez dobudowanie kilkunastu torów kierunkowych. Następnie połączono tę stację z Olechowem dwutorową łącznicą.

W tym okresie stacje były budowane wysokie, z czerwonej, nietynkowanej cegły. Dachy kryto dachówka, co odróżniało je od ówczesnego krajobrazu, gdyż w tej części Polski dominowała papa.

Rozbudowa stacji Olechów nie została zakończona w wyznaczonym terminie ze względu na działania wojenne. Przystosowano ją do potrzeb armii na froncie wschodnim poprzez oddanie torów rozrządowych na wschód i lokomotywowni. Kolejne prace rozpoczęto dopiero w 1970 r., już według zmienionych potrzeb transportowych. Zaczęto budować terminal kontenerowy. Zlikwidowano linie z Olechowa do Bedonia i utworzono nowa parę torów do Gałkówka. Pozwoliło to na oddzielenie ruchu towarowego z Olechowa od pasażerskiego do Łodzi Fabrycznej. Wybudowano obejście stacji, przesuwając na południe tory szlakowe. Tory łączące Olechów z Widzewem wykorzystano do zjazdów i wyjazdów taboru. Natomiast pociagi towarowe zaczęły jeździć druga para torów. Było to bezkolizyjne rozwiązanie. Przebudowano blachownicowy wiadukt nad ulica Tomaszowską oraz dworce pasażerskie, tworzac: Łódź Olechów Wiadukt, Łódź Olechów Wschód, Łódź Olechów Zachód. Obecnie nie istnieje tam już ruch pasażerski, który został zamknięty w maju 2001 r. Pierwszy z wymienionych dworców spłonał (został podpalony).

Kolejna inwestycja na stacji Olechów związana była z jej zautomatyzowaniem jako stacji rozrządowej. Dotychczasowe nastawnie zastapiono nowoczesnymi. Górkę rozrządową wyposażono w elektronicznie sterowane hamulce torowe.

Obecnie w województwie łódzkim prowadzonych jest kilka inwestycji związanych z rozwojem infrastruktury. Priorytetem w transporcie kolejowym jest przebudowa Dworca Fabrycznego. PKP chce stworzyć w centrum Łodzi multimedialny węzeł komunikacyjny. Planowane rozpoczęcie prac nastapiło w III kwartale 2010 r. Wybudowanie takiego

${ }^{11}$ Tamże. 
węzła daje wiele możliwości rozwojowych. Dzięki niemu powstaną połączenia kolei dużych prędkości, kolei konwencjonalnych, dworców autobusowych miejskich i podmiejskich. Inwestycja ma się składać z następujących odcinków ${ }^{12}$ :

- stworzenie dwuprzestrzennego tunelu o długości ok. 2500 m z linią czterotorową do przemieszczania się do miejscowości daleko oddalonych (poziom od 0 do $-16,5$ ),

- budowa stacji kolejowej Łódź Fabryczna jako podziemnej: dla czterech peronów i ośmiu torów wraz z zabudową czterech peronów dwukrawędziowych o długości do 400 m i ośmiu torów (poziom główki szyny, poziom od $-16,5$ do -8 ),

- skonstruowanie podziemnego dworca kolejowego Łódź Fabryczna (poziom od -8 do 0 ),

- wykonanie trzykondygnacyjnych podziemnych parkingów po północnej stronie dworca kolejowego (poziom od -17 do -8),

- wykonanie podziemnych przystanków komunikacji autobusowej po stronie północnej dworca kolejowego (poziom od -8 do 0 ),

- wykonanie i zabezpieczenie wykopu po południowej stronie dworca kolejowego (poziom od -8 do 0 ),

- wykonanie drogi dojazdowej do węzła komunikacyjnego od strony północnej dworca kolejowego po śladzie ulic Składowej i Węglowej pomiędzy ulicami Kilińskiego i projektowanego przedłużenia ulicy Uniwersyteckiej (poziom 0),

- likwidacja wszelkich kolizji infrastruktury technicznej wynikajacych z prowadzonej inwestycji,

- wykonanie odcinka linii tramwajowej po północnej stronie dworca wzdłuż ulic Składowej i Węglowej,

- wykonanie przystanków autobusowych na ulicy Węglowej,

- wykonanie niezbędnej infrastruktury do funkcjonowania węzła przesiadkowego,

- wykonanie wschodniego i zachodniego przedpola dworca kolejowego i przystanków komunikacji autobusowej łącznie z podłączeniem do układu komunikacyjnego miasta.

Realizacja tej inwestycji została rozpoczęta 15 października 2011 r. Ostatni pociąg wyjechał w godzinach wieczornych tego dnia, a wśród jego pasażerów był ówczesny minister infrastruktury C. Grabarczyk.

Aby wszystkie plany związane z projektem Dworca Fabrycznego były możliwe, muszą zostać przystosowane także inne dworce. Dlatego potrzebna jest też przebudowa innych stacji i linii kolejowych. 


\subsection{Plany budowy węzła drogowo-kolejowego Łódź Olechów i jego efekty}

Zgodnie z planami Generalnej Dyrekcji Dróg Krajowych i Autostrad w regionie łódzkim ma powstać ok. $250 \mathrm{~km}$ dróg (znacząca ich część przypada właśnie na autostradę A1, bo ok. $180 \mathrm{~km}$ ). Wśród zadań, jakie zostały ustalone dla Łodzi Olechów, zaplanowana jest m.in. zmiana części infrastruktury technicznej. Jako główne cele tej inwestycji należy wymienić ${ }^{13}$ :

- sieć wodociaggowa na ulicy Rokicinskiej,

- stworzenie części autostrady A1 z węzłem Andrespol,

- rozbudowę stacji kontenerowej Łódź Olechów,

- budowę trasy od ulicy Rokicińskiej w kierunku Koluszek,

- przedłużenie ulicy Przybyszewskiego,

- zmianę nawierzchni alei Hetmańskiej i dostosowanie jej do wymogów ulicy zbiorczej,

- rozszerzenie ulicy Puszkina do ulicy Tomaszowskiej i jezdni spajajacej ulicę Dąbrowskiego z ulicą Zakładowa,

- ulepszenie nawierzchni ulic Przybyszewskiego, Zakładowej, Tomaszowskiej, dostosowanych do ulic głównych,

- zmianę nawierzchni na częściach jezdni Bławatnej i Lodowej.

Infrastruktura drogowa w rejonie Łodzi Olechów charakteryzuje się znacznymi brakami. Dlatego tak ważne jest wybudowanie tam autostrady A1, która będzie miała za zadanie nie tylko odciążenie ruchu w centrum, lecz także dogodniejsze połączenie między przedsiębiorstwami zlokalizowanymi w tym rejonie. Władze chca, żeby A1 stała się wschodnia obwodnica Łodzi i była bezpłatna. Wzbudza to pewne kontrowersje, ponieważ miała ona zostać wybudowana przez prywatną firmę Autostrada Południe. Według informacji udzielonych przez GDDKiA, wykupione zostały już wszystkie działki przeznaczone pod budowę tej drogi. Jednak wystapił problem z wymogami technicznymi autostrady. Zostały źle zlokalizowane np. zbiorniki retencyjne. Zgodnie ze standardami powinny znajdować się dalej od przejść przeznaczonych dla zwierząt. Kolejną wada jest zaplanowanie zbyt słabych konstrukcji mostów i wiaduktów odnośnie do przewidywanego ruchu. Autostrada ma zostać zbudowana ze środków Europejskiego Banku Inwestycyjnego i środków budżetowych. Utworzona autostrada ma połączyć północ Polski z jej południem. Skrzyżuje się z autostrada A2 w Strykowie, zaś z autostradą A4 w Gliwicach. Różne były losy autostrady A1. Planowano, aby był 
możliwy zjazd z autostrady A2 na autostradę A1 lub drogę ekspresową S8 z pominięciem centrum miasta. Dlatego konieczne jest dopilnowanie pierwotnego planu budowy. GDDKiA zobowiązała się do ukończenia węzła Stryków równocześnie z doprowadzeniem do końca właściwej częścią autostrady ${ }^{14}$.

Dzięki wybudowaniu autostrady A1 w okolicach Łodzi Olechów znacznie wzrośnie konkurencyjność tego regionu. Obecnie istnieja tam następujące firmy: Foxconn (poprzednio DELL USA), Laser-Sinex, Nibco, Arise Technologies, Compal, DHL-Express, Gandon, Lekkerland, Panattoni, Paul Hartmann, SEGRO ${ }^{15}$.

Firma Foxconn jest uznana za najbardziej innowacyjną fabrykę DELL-a. Produkuje komputery oraz podzespoły do laptopów i komputerów.

Laser-Sinex zajmuje się produkcją kaset, regeneracją materiałów eksploatacyjnych do drukarek komputerowych i kas fiskalnych, bankomatów, kasowników, szpulek do maszyn do pisania i kalkulatorów, wałków barwiących i innych materiałów do urządzeń drukujących ${ }^{16}$.

Nibco to kolejna firma działająca na terenie Łodzi Olechów. Jej główna siedziba znajduje się w USA, zaś w Łodzi zlokalizowana jest przy ulicy Polskich Kolei Państwowych 6. Zajmuje się produkcja urządzeń wodnych dla zastosowań mieszkaniowych i przemysłowych. W swojej ofercie proponuje także projektowanie całej instalacji sanitarnej oraz nadzór po jej założeniu. Chce powiększać swój zakład produkcyjny.

Arise Technologies mieści się przy ulicy Zakładowej 97. Jest liderem nowoczesnych, oszczędnych technologii opartych na energii słoneczne ${ }^{17}$. Firma ta dba przede wszystkim o zapewnienie klientowi jak największej satysfakcji poprzez skrócenie czasu dostawy. Główna siedziba przedsiębiorstwa znajduje się w Irlandii, ma też swoje zakłady w Kanadzie i Niemczech.

Firma Compal zajmuje się dostawą i montażem instalacji klimatyzacyjnej w oparciu klimatyzator firmy LG typu G09AH oraz instalacji odciągów miejscowych z zastosowaniem wentylatora KD 355 XL1 firmy Systemair ${ }^{18}$. Działa przy ulicy Żeromskiego 94B/C i ulicy Gdańskiej 81 w Łodzi.

${ }^{14}$ www.uml.lodz.pl/index.php?str=1333 [z dn. 13.11.2011].

${ }^{15}$ Biuletyn Informacyjny Biura Rozwoju Przedsiębiorczości i Miejsc Pracy Urzędu Miasta Łodzi.

${ }^{16}$ www.laser-sinex.pl [z dn. 11.10.2012].

17 www.microsofttranslator.com/BV.aspx?ref=BVNav\&a=http $\% 3 A \% 2 F \% 2 F$, www.arisetech.com\%2Fcontent\%2Fview\%2F13\%2F49\%2F [z dn. 16.12.2011].

${ }^{18}$ www.ventra.com.pl/referencja,ref,748.html [z dn. 11.10.2012]. 
DHL-Express posiada swoje placówki na całym świecie. Swoja siedzibę w Łodzi ma przy ulicy Targowej 35 oraz ulicy św. Teresy od Dzieciątka Jezus 103b. Zajmuje się przewozem paczek i listów przy użyciu różnych środków transportu na wszystkie kontynenty. DHL-Express uważany jest za lidera usług ekspresowych w świecie. Główna centrala znajduje się w Niemczech (Bonn). Przy ulicy Targowej mieści się Dział Reklamacji. Według danych z 2009 r. DHL-Ekspress zatrudnia ok. 100 tys. pracowników. Trzeba jednak zaznaczyć, że liczba ta stale rośnie, ponieważ ten sektor usług z roku na rok się rozwija ${ }^{19}$. Na portalach internetowych ciaggle pojawiaja się nowe oferty pracy z DHL-Express dla Łodzi.

Dzięki pojawieniu się w 2007 r. firmy DELL na Olechowie, utworzono nowe miejsca pracy. Wraz z tym zakładem powstały inne przedsiębiorstwa. Jednym z nich jest Gandon Logistics. Zajmuje się wykonywaniem napisów i nadruków na wyrobach DELL-a. Według danych z 2007 r. zatrudnia ok. 100 osób, w tym także osoby niepełnosprawne ruchowo i umysłowo ${ }^{20}$.

Firma Lekkerland zajmuje się dostawą tzw. artykułów impulsowych (artykuły gotowe do spożycia, np. gotowe kanapki, napoje w puszce, czekoladowe batoniki). Przy ulicy Zakładowej znajduje się Centrum Dystrybucyjne. W Polsce zatrudnia 562 osoby ${ }^{21}$.

Panattoni Park Business Center Łódź na Widzewie to innowacyjny park biznesowy położony $6 \mathrm{~km}$ od centrum miasta, w bliskiej odległości od fabryki DELL-a. W swojej ofercie wynajmu posiada hale i magazyny produkcyjne. Wokół Panattoni Parku Łódź East powstała sieć dróg w celu umożliwienia dojazdu potencjalnym inwestorom.

Firma Paul Hartmann oferuje szeroką gamę produktów z zakresu medycyny i opieki (materiały opatrunkowe i higieniczne, sprzęt ortopedyczny, zestawy chirurgiczne). Hurtownia mieści się przy ulicy Zakładowej 97.

SEGRO to innowacyjne parki biznesowe zlokalizowane $\mathrm{w}$ centrum Polski (Łódź). Przedsiębiorstwo jest położone na powierzchni 6,7 ha u zbiegu ulic Hetmańskiej i Rokicińskiej (droga krajowa nr 713 na Tomaszów Mazowiecki). Wielkość parku oraz planowana druga faza o powierzchni 20 ha umożliwiają przyjazne warunki rozwoju i ekspansji dla najemców ${ }^{22}$.

Zgodnie z danymi Urzędu Miasta Łodzi, zostały wznowione prace przy budowie dróg dojazdowych do autostrady A1. Mają one umożliwić odcią-

\footnotetext{
${ }^{19}$ www.dhl.com.pl/pl/o_nas/express.html\#facts_figures [z dn. 11.10.2012].

20 http://uml.lodz.pl/index.php?str=1152\&id=11211 [z dn.17.12.2011].

${ }^{21}$ www.lekkerland.pl/le/pl/company/facts/Facts.html [z dn. 11.10.2012].

${ }^{22}$ www.segro.pl/upload/folder_Tulipan_Park_Lodz.pdf [z dn.18.05.2010].
} 
żenie ruchu w centrum Łodzi. Planuje się przebudowę ulicy Śląskiej od skrzyżowania alei Ofiar Terroryzmu 11 Września i ulicy Informatycznej do ulicy Rokicińskiej, z jej przebudową na odcinku do "Selgrosa” (okoto $730 \mathrm{~m}$ ). Dwie ostatnie ulice służą obecnie firmie Foxconn (dawniej DELL), Panattoni, ale również umożliwią lepsze połączenie komunikacyjne na Olechowie. W planach ulica Śląska ma być dwujezdniowa (szerokość jednego pasa ma wynosić ok. $7 \mathrm{~m}$ ), rozdzielona pięciometrowym pasem zieleni. $Z$ jednej strony ma się znajdować chodnik i wydzielona ścieżka dla rowerów. Prace realizują firmy: KRAL Sp. z o.o. oraz UNIDRO S.A. ${ }^{23}$ Ulica Śląska oprócz tego, że jest główna droga dojazdową do firmy Foxconn, ma połączyć to przedsiębiorstwo z planowaną autostradą $A 1^{24}$. Według informacji udzielonych przez GDDKiA zostały już wykupione wszystkie działki pod budowę autostrady na Olechowie. Planowane ukończenie prac ma nastapić w 2015 r.

Do inwestycji, które maja być zrealizowane w Łodzi Olechów należy również modernizacja stacji rozrządowej. Obecnie stacja ta jest bardzo zaniedbana i wymaga wielu nakładów finansowych, aby móc w pełni z niej korzystać. Zamieszczone zdjęcie pokazuje jej aktualny wygląd. Stacja towarowa Olechów uważana jest za największą tego typu stację w Europie, dlatego jej modernizacja znacząco wpłynie na dalszy rozwój Łodzi.

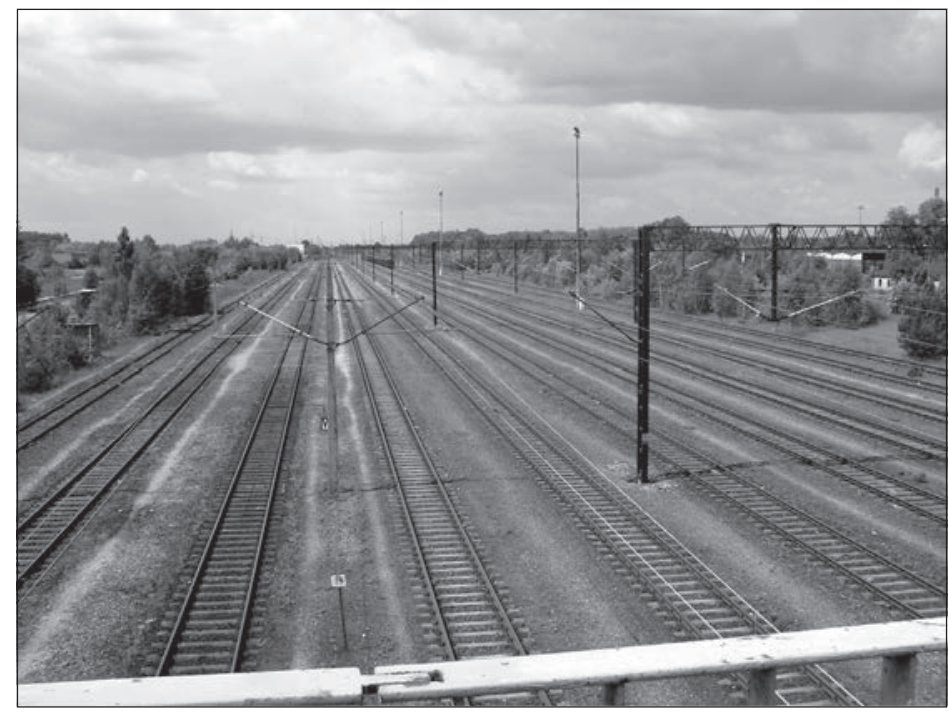

Rysunek 12. Wschodnia głowica stacji Olechów (fot. Remigiusz Kozłowski)

\footnotetext{
${ }^{23}$ http://uml.lodz.pl/index.php?str=1200\&id=15934 [z dn.19.12.2011].

${ }^{24}$ www.zdit.uml.lodz.pl/index.php?str=46\&id=535 [z dn.19.12.2011].
} 
Biuro Projektowania Kolei i Usług Inwestycyjnych Sp. z.o.o. opracowało dla PKP koncepcje budowy i przebudowy wielu linii, stacji i przystanków, w tym budowę nowoczesnej stacji rozrządowej Łódź Olechów ${ }^{25}$.

W regionie Łódzi Olechów w najbliższym czasie przewidziano wiele inwestycji, które przyniosa efekty $w$ postaci m.in. zwiększenia liczby miejsc pracy, ale także rozwoju infrastrukturalny rejonu. Dzięki pojawieniu się nowych przedsiębiorstw w Łodzi Olechowie nastapiło znaczace poprawienie stanu dróg. Rozbudowano też ulicę Śląską.

\section{Podsumowanie}

W wyniku analiz przeprowadzonych w niniejszym rozdziale sformułowano następujące wnioski:

- W infrastrukturze drogowej i kolejowej w Polsce widać postępy - powstaja nowe odcinki, a dotychczasowe sa modernizowane. Także w województwie łódzkim powstaja nowe odcinki torów kolejowych i dróg.

- W Łodzi Olechów nastapi modernizacja stacji rozrządowej i towarowej. Będzie to największa tego typu stacja w Polsce, a może nawet w całej Europie. Sassiedztwo z autostrada A1 daje dogodne warunki dla inwestorów. W tym rejonie zmodernizowano ulice:

- Śląska,

- Rokicińska,

- Puszkina,

- Tomaszowska,

- Dąbrowskiego z ulica Zakładowa,

- Przybyszewskiego.

Dzięki takim inwestycjom Łódź Olechów staje się rejonem, który wpływa na poprawę gospodarczą Łodzi.

${ }^{25}$ www.bpk.lodz.pl/realizacje.html [z dn.11.10.2012]. 



\section{Węzeł kolejowy w Karsznicach}

Anita Kącka*

\subsection{Geneza powstania i historia rozwoju węzła kolejowego w Karsznicach}

Dla Polski po odzyskaniu niepodległości w 1918 r. $^{1}$ ważne było odbudowanie swojej gospodarki, m.in. poprzez szybkie uruchomienie transportu kolejowego. To od skuteczności działania kolei zależało: czy kraj zostanie prawidłowo zaopatrzony w surowce i materiały, jak szybko rozwinie się organizacja administracji oraz czy obrona granic państwa jest wystarczająca². Celem było m.in. zbudowanie linii kolejowej, która łączyłaby północ z południem, tj. Gdynię z Górnym Śląskiem, gdyż eksport węgla stwarzał korzystne warunki dla rozwoju państwa. Jednak $1 / 3$ węgla trafiała do Niemiec $i$ istniejąca infrastruktura kolejowa znajdowała się na trenie Niemiec bądź Czechosłowacji. Niestety, transport przez te państwa często był utrudniony, głównie przez Niemcy. Dodatkowo wymagał on dużego parku wagonów, węglarek, którymi Polskie Koleje Państwowe nie dysponowały.

Podpisana w 1922 r. przez Niemcy i Polskę Konwencja Genewska ${ }^{3}$ zawierała postanowienia dotyczące regulacji spraw ludnościowych i własnościowych wynikających z włączenia do Polski większej części Górnego Śląska. Konwencja ta gwarantowała Niemcom m.in. bezcłowy wywóz produktów, które pochodziły z Górnego Śląska na okres 3 lat. Z niekorzystnego dla Polski przebiegu granic wynikły problemy z transportem surowców i produktów, głównie między Zagłębiem Górnośląskim a Wielkopolską i wybrzeżem. Poznań został odcięty przez tzw. korytarz kluczborski, wybrzeże przez obszar Wolnego Miasta Gdańska, a transport do Tarnowskich Gór został zamknięty przez Bytom. Dodatkowo sy-

${ }^{*}$ Mgr Anita Kącka - Katedra Logistyki, Wydział Zarządzania Uniwersytetu Łódzkiego, ul. Matejki 22/26, 90-237 Łódź.

${ }^{1}$ Encyklopedia Popularna PWN, Wyd. Naukowe PWN, Warszawa 1995, s. 661.

2S. M. Koziarski, Sieć kolejowa Polski w latach 1918-1992, Instytut Ślaski, Opole 1993, s. 7.

${ }^{3}$ Encyklopedia Popularna PWN, s. 251. 
tuację pogarszał fakt, iż po podpisaniu konwencji wygasł 3-letni okres przyjmowania przez Niemcy węgla. W momencie, gdy Niemcy odmówiły dalszej współpracy, rozpoczałł się konflikt polsko-niemiecki zwany wojną celną. Oba kraje określiły szereg ograniczeń handlowych względem siebie, m.in. Niemcy nie importowały węgla z Polski, a Polska nie importowała towarów z Niemiec. Zatem niesprzyjający podział granic i wojna celna doprowadziły do tego, że strona Polska zaczęła szukać nowych rynków zbytu dla polskiego węgla.

Nadarzyła się okazja, gdyż wiosną 1926 r. wybuchł strajk górników brytyjskich ${ }^{4}$. Zaprzestano wydobycia węgla i główni odbiorcy - kraje skandynawskie - nie posiadały już swoich stałych źródeł dostaw węgla. Przed Polską otworzyły się rynki skandynawskie.

By móc dostarczać węgiel w relacji północ-południe, trzeba było opracować plan modernizacji bąź plan budowy nowej linii kolejowej łączącej Śląsk z Bałtykiem tak, by omijała połączenie GdańskMalbork-Prabuty-Iława, które były pod rządami Niemiec, a także węzeł w Bytomiu i Kluczborku.

Pierwszy etap prac nad linią węglową rozpoczęto już w $1925 \mathrm{r}^{5}$ Sejm uchwalił wówczas ustawę, w której godził się na budowę dwóch pierwszorzędnych, normalnotorowych linii kolejowych użytku publicznego. Pierwsza linia znajdowała się na północy kraju, łącząc Bydgoszcz przez Maksymilianowo i Kościerzynę z Gdynią, a druga na południu łaczyła Kalety-Herby Nowe-Wieluń-Podzamcze (dzisiejszy Wieruszów). Obie linie były niezwykle istotne, gdyż pierwsza z nich omijała obszar Wolnego Miasta Gdańska, a druga pozwoliła obejść niemiecki tzw. korytarz kluczborski. "Od Wielunia miała się linia odgałęziać w kierunku Inowrocławia. Projektu w tym kształcie jednak nie zrealizowano"6. Istniejąca wówczas linia była jedynie rozwiązaniem doraźnym. Mimo że łączyła ze sobą Górny Śląsk z wybrzeżem poprzez Kępno-Jarocin-Inowrocław, była mało wygodna, gdyż wydłużona trasa przyczyniała się do wzrostu kosztów transportu. W tym momencie zaistniała potrzeba połączenia trasy Kalety-Herby Nowe z Bydgoszczą-Gdynią nową linią tranzytową. Było to możliwe dzięki rozporządzeniu prezydenta Ignacego Mościckiego z 17 lutego 1928 r. $^{7}$

4 J. Chrzanowski, Siedemdziesiąt lat magistrali węglowej, "Nasz Tygodnik", 21.05.2010, dodatek do "Dziennika Łódzkiego", s. 6.

5 J. Śmiałowski, Zakład Taboru Polskich Kolei Państwowych w Zduńskiej WoliKarsznicach (rok zał. 1933), Wyd. Biblioteka, Zgierz 1996, s. 12.

${ }^{6}$ C. Borowski, S. Koniecki, Dzieje powstania i rozwój Gdańskiego Okręgu Kolejowego, Gdańsk 1970, [w:] S. M. Koziarski, Sieć kolejowa Polski..., s. 20.

${ }^{7}$ K. Woźniak, Francuską koleją przez Karsznice, "Ziemia Łódzka" 2009, nr 10 (99), październik, s. 20. 
Rozporządzenie to upoważniało rząd do budowy kolei od stacji Herby przez Zduńską Wolę, dalej Barłogi do Inowrocławia o ogólnej długości ok. 255 km. Ostatecznie ustalono przebieg trasy magistrali węglowej: Katowice-Tarnowskie Góry-Kalety-Herby Nowe-SiemkowiceZduńska Wola-Karsznice-Barłogi-Inowrocław-Nowa Wieś-BydgoszczMaksymilianowo-Szlachta-Kościerzyna-Gdynia (rys. 13).

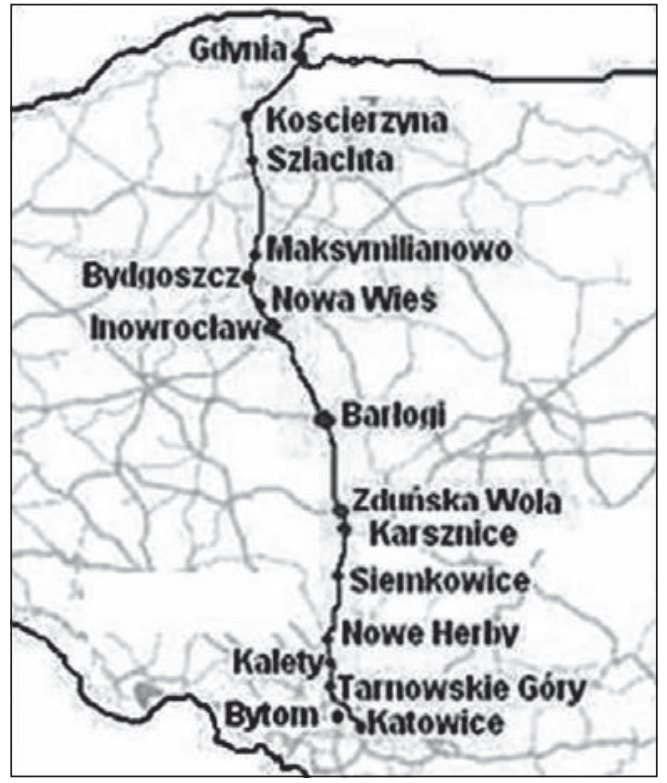

Rysunek 13. Przebieg Magistrali Węglowej

Źródło: opracowanie - Anna Zmysłowska

Budowę nowego odcinka Herby Nowe-Karsznice zaczęto jeszcze w $1928 r^{8}{ }^{8}$ Prace nad odcinkiem prowadziła poznańska firma TRI - Towarzystwo Robót Inżynieryjnych. Środki na budowę przeznaczone były z budżetu państwa. Pierwszy odcinek, jaki oddano do użytku to Herby Nowe (na linii Tarnowskich Gór do Wielunia) - Karsznice (dzisiejsza stacja Zduńska Wola Karsznice) 8 listopada 1930 r. (odcinek południowy). Natomiast drugi odcinek północny BydgoszczGdynia oddano 9 listopada 1930 r. Zatem nowa trasa pociaggów prowadziła z Tarnowskich Gór przez Herby Nowe do Karsznic, później na Skalmierzyce i Inowrocław. Przepustowość tego odcinka wynosiła od 6 do 8 par pociągów na dobę. Na rys. 14 widnieje zdjęcie pierwszego pociaggu z węglem na stacji Zduńska Wola.

8 J. Śmiałowski, Zakład Taboru Polskich Kolei Państwowych..., s. 13. 


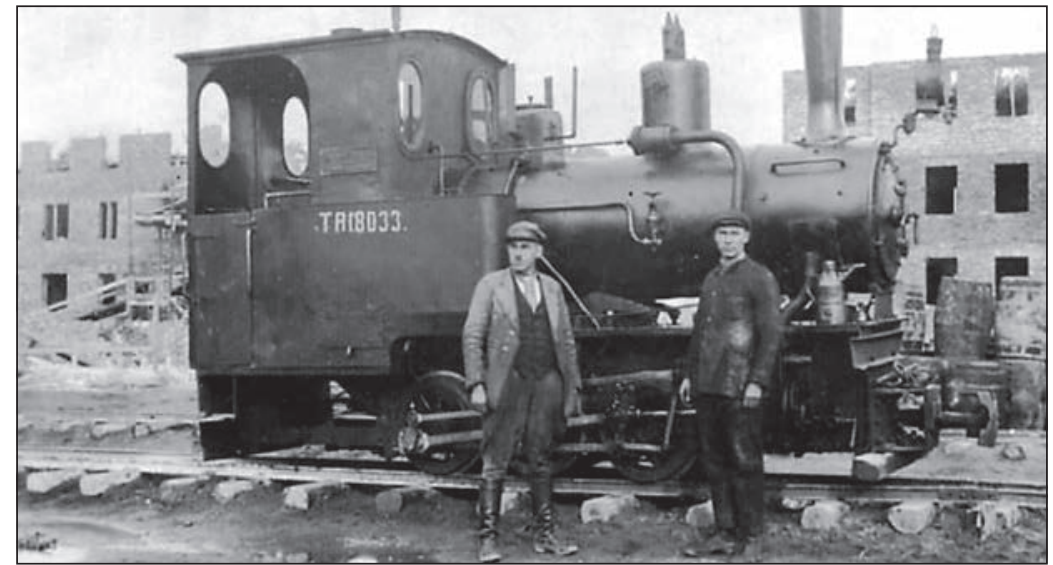

Rysunek 14. Pociąg z węglem na stacji Zduńska Wola

Źródło: K. Woźniak, Francuską koleja przez Karsznice, „Ziemia Łódzka" 2009, nr 10 (99), s. 20

Zakończenie prac budowlanych planowano na 1930 r. Niestety, światowy kryzys gospodarczy przyczynił się do braku środków na dalszą budowę odcinka Karsznice-Inowrocław. Podjęto wówczas decyzję, by dalszą budowę wykonała firma z kapitałem obcym. Rząd udzielił koncesji Francusko-Polskiemu Towarzystwu Kolejowemu S.A. w Paryżu. Kapitał firmy FPTK w wysokości 15 mln franków został zgromadzony poprzez wypuszczenie obligacji zagwarantowanych przez polski rząd ${ }^{9}$. Jednym z elementów partnerstwa była możliwość użytkowania linii przez 45 lat przez francuską firmę z opcja, że rządowi polskiemu przysługuje prawo do wykupu po 20 latach. Prace nad odcinkiem miały trwać 3 lata i po zakończeniu budowy towarzystwo zobowiązało się do płacenia $12 \mathrm{mln}$ franków polskiemu rządowi. Niestety, skutki kryzysu przyczyniły się do tego, że i towarzystwo nie miało pieniędzy na inwestycję, a tym samym nie dotrzymało terminów budowy. Mimo że prac nie ukończono w pełni, odcinek Karsznice-Inowrocław oddano do użytku 1 marca 1933 r. ${ }^{10}$ Cała linia węglowa została uruchomiona w 1939 r. Niemalże równocześnie otwarto na odcinku Karsznice-Siemkowice drugi tor (44 km).

W 1936 r. została utworzona Dyrekcja Kolei Herby Nowe-Gdynia z siedziba w Bydgoszczy. Dyrekcja ta podlegała francuskiemu towarzystwu. Linia ta została utworzona ze względu na swoja specyfikę. Do dnia 1 stycznia 1938 r. magistrala ta była własnością państwowa, gdyż przedsiębiorstwo francuskie przejęło od PKP eksploatację magistrali i stała się ona własnościa prywatną.

\footnotetext{
${ }^{9}$ K. Woźniak, Francuską koleją przez Karsznice..., s. 20.

10 J. Śmiałowski, Zakład Taboru Polskich Kolei Państwowych..., s. 15.
} 
Wraz z węzłem powstała parowozownia i osiedle mieszkaniowe. Parowozownia została uruchomiona w tym samym czasie, co oddano do użytku odcinek Herby Nowe-Zduńska Wola Karsznice. Do budowy przyczyniło się to, że istniejące dotychczas parowozownie znajdowały się 40 km w bok od nowo wybudowanej linii. Do warsztatu na przegląd lub naprawę bieżąca trafiały wszystkie parowozy przebiegające przez Karsznice. Niestety, powołanie do życia parowozowni w Karsznicach wymagało skompletowania załogi, która miałaby już doświadczenie w naprawach parowozów. Postanowiono przenieść część personelu z innych parowozowni. Zagwarantowano mu mieszkania i tym samym powstało kolejarskie osiedle mieszkaniowe.

Po II wojnie światowej węzeł kolejowy odbudowywano i rozbudowywano. W latach 1964-1969 zelektryfikowano linię z Tarnowskich Gór przez Karsznice do Gdyni ${ }^{11}$.

\subsection{Aktualna sytuacja Karsznic}

Karsznice to niegdyś mała wieś, a teraz dzielnica miasta Zduńska Wola. W 1960 r. uzyskała prawo osiedla, a w 1973 r. została włączona do miasta Zduńska Wola ${ }^{12}$. Ogólna powierzchnia miasta Zduńska Wola ${ }^{13}$ to 2458 ha $=25 \mathrm{~km}^{2}$, w skład tego wchodzi m.in. obręb 26, 27, które stanowia powierzchnię osiedla Karsznice, a obręb 18 stanowi powierzchnię lokomotywowni wraz z torami biegnạcymi do wiaduktu drogowego. Zatem łącznie powierzchnia Karsznic z lokomotywownia wynosi około 306 ha $(305,7751 \text { ha })^{14}$. Natomiast ludność osiedla Karsznice oscyluje około 4044 osób ${ }^{15}$.

Największy rozkwit Karsznic nastapił podczas budowy tzw. Magistrali Węglowej. Dzięki przebiegającej linii zostało wybudowane osiedle dla kolejarzy i ich rodzin, którzy znaleźli pracę w pobliskiej lokomotywowni (została później przekształcona w Zakład Taboru PKP ze względu na restrukturyzację zakładu).

${ }^{11}$ R. Poradowski, Zduńska Wola i okolice, Tow. Przyjaciół Zduńskiej Woli, Zduńska Wola 1984, s. 21.

12 Poradowski R., Zduńska Wola i okolice, s. 21.

${ }^{13}$ www.stat.gov.pl/bdr_n/app/dane_cechter.wymiary?p_nts=5\&p_szuk=Radom\&p_te$r y=1521 \& p \_d a n e=0 \& p \_k a t e=1 \& p \_c z a s=15 \& p \_w y j s c i e=1 \# F O R M U L A R Z[z d n .11 .10 .2012]$.

${ }^{14}$ Wartości powierzchni udostępniono autorce dzięki uprzejmości Pań urzędniczek w Starostwie Powiatowym w Wydziale Geodezji, Kartografii, Katastru i Gospodarki Nieruchomościami przy ulicy Królewskiej 10.

${ }^{15}$ Informacji udzielono w Biurze Ewidencji i Dowodów Osobistych w Zduńskiej Woli. 
Lokomotywownia posiadała ok. 25 torów wprowadzających lokomotywy do hal naprawczych (jeden duży budynek składający się z kilkunastu hal naprawczych, jedna obok siebie tzw. hala czołowa - rys. 15), natomiast na dzień dzisiejszy może działa 10 - większość torów jest nieczynnych, nieużywanych ${ }^{16}$. W skład węzła wchodzi również tzw. wagonówka. Tutaj dokonuje się napraw rewizyjnych wagonów, typu czyszczenie, malowanie itp. Dla poprawy obsługi wagonów wybudowano również acetylenownię, która działa do dzisiaj. Posiadanie własnego bezpośredniego dostępu do acetylenu (wykorzystywany w spawaniu i cięciu metali) nie powodowało problemów z dostawcami i jego ewentualnym brakiem, co hamowałoby pracę. Do tego wykorzystywana jest hala 6 i 7. Wyróżniamy również dział, w którym dokonuje się napraw zestawów kołowych. Dokonuje się pomiaru kontrolnego rozkładu nacisków w zestawie kołowym, obróbki zestawów kołowych, naprawia się obrzeża obręczy zestawów kołowych, wyważa się silniki, następuje regeneracja łożysk. Wszystkie te czynności składają się na to, by lokomotywa pracowała sprawnie, bez żadnych usterek.

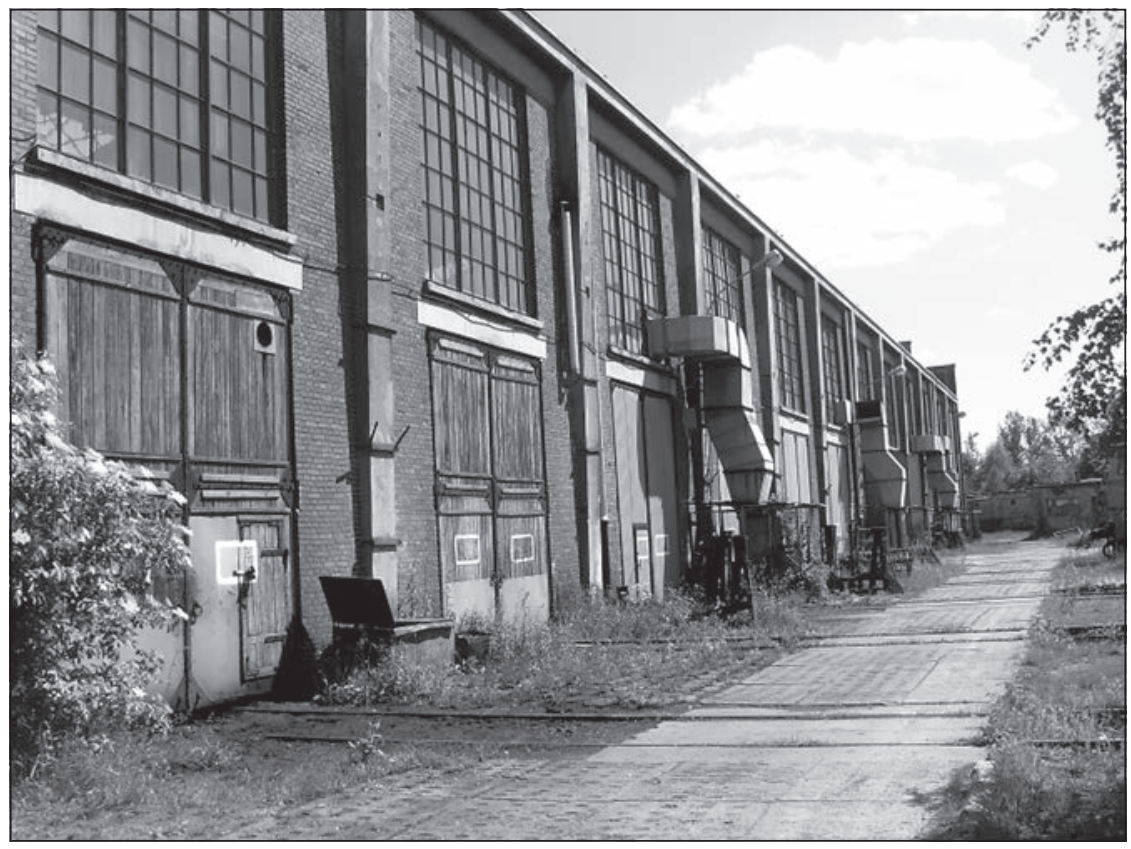

Rysunek 15. Hale naprawcze lokomotyw (fot. Anita Kącka)

${ }^{16}$ Janusz Szczepański, autoryzowane wspomnienia w posiadaniu autora. 
Na węźle karsznickim wyróżniamy jeszcze dwie stacje: Zduńska Wola i Zduńska Wola Karsznice. Ich specyfika jest to, że każda z tych stacji leży na odrębnej linii. Jedna leży na linii Łódź Kaliska-Frost (linia nr 14), a druga na linii Śląsk-Porty (linia nr 131). Połączone są ze sobą dzięki łącznicom. Na tym węźle występuje ich aż $4^{17}$. Pierwsza z nich to właśnie linia 739: Zduńska Wola-Zduńska Wola Karsznice i biegnie ona z zachodu na południe. Druga linia to 810: Zduńska Wola-Dionizów i biegnie z zachodu na północ. Dionizów to posterunek odgałęźny, gdzie do "węglówki" dochodzą łączniki ze Zduńskiej Woli i Gajewnik (głównie z kierunku Łodzi). Trzecia linia, która odgrywa też rolę łącznicy, to linia 543: Gajewniki-Dionizów. Linia ta biegnie ze wschodu na północ. Gajewniki jest drugim posterunkiem odgałęźnym występującym w tym węźle. Ostatnia linia to 542 i biegnie z Borszewic (przystanek osobowy) do Zduńskiej Woli Karsznic. Tutaj z kierunku wschodniego, od Łodzi, pociągi moga poruszać się na południe do Magistrali Węglowej. Zatem największą zaletą tego węzła jest możliwość poruszania się pociągów we wszystkie 4 kierunki świata.

Długości torowisk są następujące ${ }^{18}$ : Zduńska Wola-Dionizów: 3,30 km, Zduńska Wola-Zduńska Wola Karsznice: 4,9 km, GajewnikDionizów: 2,15 km, Borszewice-Zduńska Wola Karsznice: 7,2 km, Zduńska Wola Karsznice-Dionizów: 4,85 km, Borszewice-Zduńska Wola: 7,1 km.

Niedaleko stacji Zduńska Wola na wschód znajduje się wiadukt, będący skrzyżowaniem dwóch linii: Łódź Kaliska-Frost (na dole) i ówczesnej Magistrali Węglowej (u góry). Skrzyżowanie to przedstawia zdjęcie na rys. 16 (widok od strony wschodniej ku stacji Zduńska Wola). Pod wiaduktem ku wschodowi biegna po dwie pary torów, z czego jeden tor od strony zewnętrznej, po prawej stronie zdjęcia, przekształca się w łącznicę ku północy (linia 810) i również tor od strony zewnętrznej, po lewej stronie zdjęcia, przekształca się w łącznicę na południe (linia 739). Po torach wewnętrznych poruszają się pociągi w relacji wschód-zachód. Niegdyś planowano budowę nowego dworca w Zduńskiej Woli, który miał właśnie znajdować się przy wiadukcie na skrzyżowaniu tych dwóch linii i dlatego istniejące międzytorza na wiadukcie i pod nim są szerokie, ponieważ miały znajdować się tam perony ${ }^{19}$. Jednak planów nie zrealizowano ani przed wybuchem II wojny światowej, ani po.

17 http://zsk.dbv.pl/articles.php?cat_id=1 [z dn. 11.10.2012].

${ }^{18}$ Opracowanie własne na podstawie: www.kolej.one.pl [z dn. 07.12.2011], http://kolej.krb.com.pl/d29/d29lacz.htm [z dn. 11.10.2012], ze względu na różnice w danych, wartości długości torowisk zostały uśrednione.

19 Jacek Zaborowski, autoryzowane wspomnienia w posiadaniu autora. 


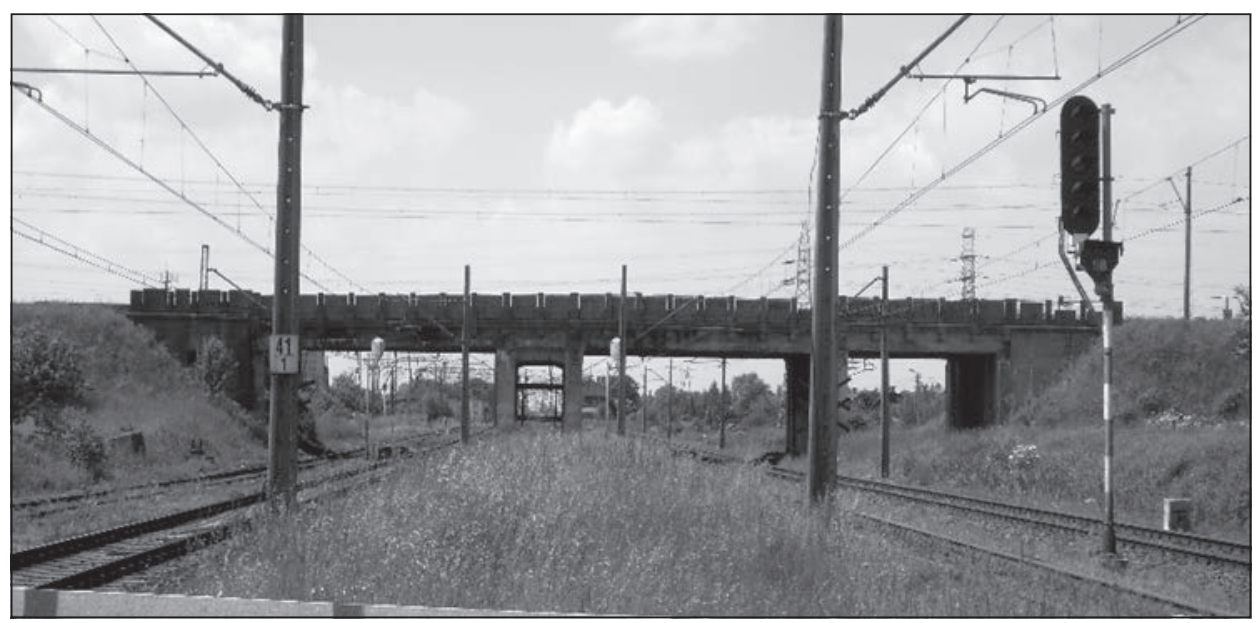

Rysunek 16. Wiadukt łączący linie kolejowe nr 14 i 131

(fot. Anita Kącka)

Dodatkowo na linii 131 znajduje się jeszcze jeden wiadukt. Jest to wiadukt drogowo-kolejowy. Przebiega przez niego droga krajowa 14 $z$ Łodzi do Sieradza. Biegnące pod wiaduktem tory prowadza w kierunku południowym do stacji Zduńska Wola Karsznice. Stacja ta posiada 3 perony i 4 tory postojowe ${ }^{20}$. Pierwszy peron obsługuje jedynie drezyny wyjeżdżające ze swojego garażu. Przez drugi peron przejeżdżaja pociągi pasażerskie oraz składy towarowe poruszające się dalej ku północy "węglówka". Natomiast peron trzeci służy składom towarowym jadącym w kierunku wschodnim lub zachodnim za pomoca łącznicy do Zduńskiej Woli lub Gajewnik. Obecnie dworzec Zduńska Wola Karsznice jest zamknięty wraz z kasą biletowa.

Dalej w kierunku południowym znajduje się przystanek osobowy Zduńska Wola Południe. Kiedyś pociągi osobowe jadące w kierunku Częstochowy i Katowic tu się zatrzymywały. Na dobę było ich około 10, ale niestety przystanek ten jest zamknięty już od kilku lat i popada w ruinę ${ }^{21}$. Przy przystanku tym istnieje grupa torów (rys. 17), która została wybudowana w systemie japońskim i jako pierwsza w Polsce. Grupa ta pełniła rolę stacji rozrządowej Zduńska Wola Karsznice, czyli przyjmowano, przepinano i na nowo formowano nowe składy towarowe w zależności od kierunku jazdy.

\footnotetext{
${ }^{20}$ http://zsk.dbv.pl/articles.php?cat_id=1 [z dn. 07.12.2011].

${ }^{21}$ Janusz Szczepański, autoryzowane wspomnienia w posiadaniu autora.
} 


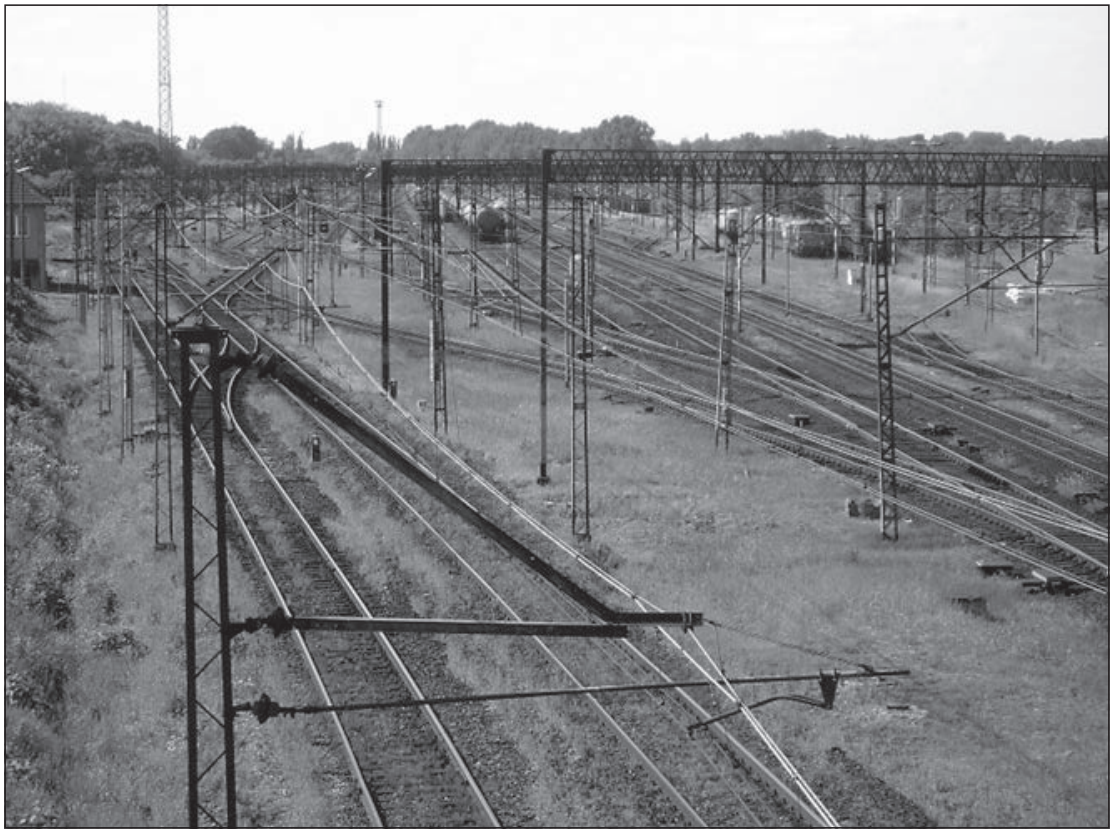

Rysunek 17. Stacja rozrządowa

(fot. Anita Kącka)

W skład tej stacji rozrządowej wchodziło 12 torów, z czego 4 tory zostały przeznaczone na szybki przegląd i ewentualną naprawę wagonów, które zostały wyłączone z ruchu²2. Pociągi wjeżdżające i wyjeżdżające zmieniały się co 6 minut, tak dobrze prosperowała ta stacja ${ }^{23}$.

W skład węzła karsznickiego wchodziły również bocznice, które głównie wyprowadzone były ze stacji Zduńska Wola. Większość bocznic została zlikwidowana. Pierwszą taką bocznica jest ta wychodzaca ze stacji w kierunku zachodnim do Gminy Spółdzielczej „Opiesin”. Po bocznicy pozostał tylko dół, który zarósł trawą (rys. 18). Jedyny ślad istniejącej bocznicy to kawałek odcinka torów przebiegający przez szerokość ulicy Opiesińskiej (rys. 19), prowadzący obecnie do hurtowni papierosów „BETA".

Bocznica do Polskich Zakładów Zbożowych Zduńska Wola i do GS Zduńska Wola są jedynie nieczynne, torów nie usunięto. Czasami z torów bocznicy do GS „Zduńska Wola” korzysta firma „Dromak”, która rozładowuje wagony z kruszywem, piachem itp. (informacji udzielił mi Pan wynajmujący stary budynek po GS „Zduńskiej Woli”). Następna bocznica została rozebrana i tak, jak w przypadku bocznicy do GS „Opiesin”,

\footnotetext{
22 Tamże.

23 Tamże.
} 
jedyny ślad istniejącej wówczas bocznicy to odcinek w drodze. Bocznica ta prowadziła do Zakładu Przemysłu Bawełnianego "Zwoltex". Jedyna czynna bocznica prowadzi do zakładu "Icopal” i zakończona jest stacją zakładowa. Od tej bocznicy sa poprowadzone dwie kolejne bocznice. Jedna prowadzi do zakładu "Lampogaz". Składy transportowane sa za pomoca wagonów cystern, w których znajduje się gaz. Natomiast druga prowadzi do Elektrociepłowni "Zduńska Wola" i też jest czynna.

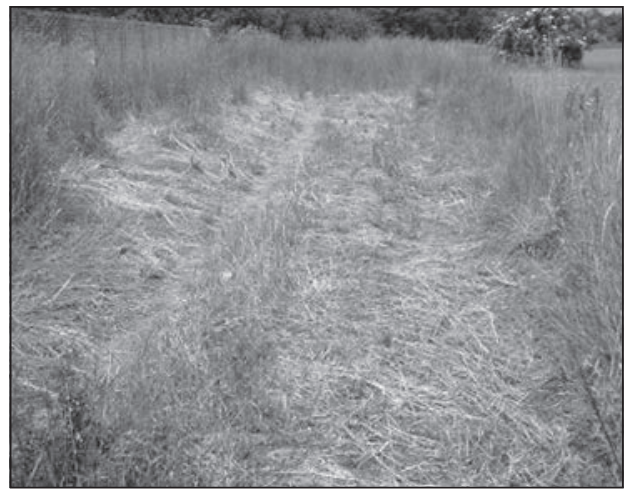

Rysunek 18. Dół po bocznicy (fot. Anita Kącka)

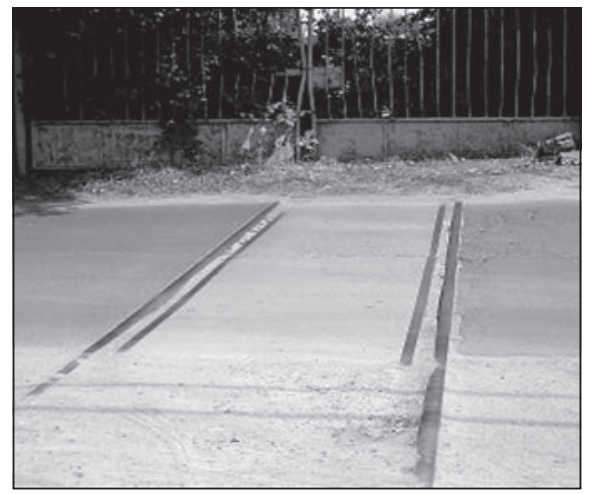

Rysunek 19. Istniejący odcinek bocznicy (fot. Anita Kącka)

Przyczyną zamknięcia większości bocznic jest rezygnacja z transportu kolejowego na rzecz transportu samochodowego. Gminne spółdzielnie po likwidacji monopolu na handel węglem albo przestały istnieć, albo zostały przejęte przez nowych właścicieli, dla których transport samochodowy stał się wygodniejszym i bardziej opłacalnym środkiem transportu24.

Na terenie lokomotywowni znajduje się Skansen Lokomotyw. Powstał w listopadzie 1993 r. ${ }^{25}$ Obok skansenu w budynku po byłej olejarni mieści się Izba Historii Zakładu Taboru Kolejowego w Karsznicach ${ }^{26}$. Skansen prezentuje stare lokomotywy i urządzenia kolejowe. Można obejrzeć m.in.: wirowy pług odśnieżny typu W14, pierwszy elektrowóz ET21-1, parowozy serii Ty23, Ty51 oraz kilka lokomotyw spalinowych i manewrowych. Natomiast w Izbie Historii Zakładu Taboru Kolejowego można obejrzeć modele lokomotyw, liczne zdjęcia pracowników zakładu i typów parowozów, dokumenty ${ }^{27}$. Niestety, lokomotywy są w opłakanym stanie, widać po nich upływ czasu, a PKP nie ma pieniędzy na ich utrzymywanie.

24 Jacek Zaborowski, autoryzowane wspomnienia w posiadaniu autora.

25 http://miasteria.pl/miejsce/Skansen-lokomotyw-w-Karsznicach.html [z dn.

17.12.2011].

26 Janusz Szczepański, autoryzowane wspomnienia w posiadaniu autora.

27 Tamże. 


\subsection{Uwarunkowania rozwoju węzła kolejowego w Karsznicach}

Nieodzownym warunkiem rozwoju danego regionu jest możliwość zatrudnienia ludzi. Poprzez tworzenie nowych miejsc pracy podnoszona jest jakość życia mieszkańców. Dzięki oferowaniu dobrze płatnych miejsc pracy następuje napływ ludności z wiedzą i doświadczeniem, które na rynku sa bardzo poszukiwane. By zapewnić atrakcyjność terenu, pobudzić postęp gospodarczy, zapewnić swobodę w poruszaniu się klientów, należy dostosowywać infrastrukturę transportową. Posiadanie odpowiednich dróg, autostrad, lotnisk, stacji i terminali kolejowych, połączeń lotniczo-drogowo-kolejowych stanowi główny czynnik lokalizacyjny ${ }^{28}$. Dostępność i jakość tej infrastruktury przyczynia się do tego, że firmy wybierają te tereny, na których moga się swobodnie rozwijać.

W sprawnym funkcjonowaniu przedsiębiorstw najważniejszą rolę pełnia węzły komunikacyjne, czyli miejsca, w których styka się kilka różnych dróg, głównie drogi z lotniskiem i drogi z koleją ${ }^{29}$. Z takiego połączenia wynika przede wszystkim skrócenie odległości między dwoma punktami. Zmniejsza się czas dowozu danego ładunku z punktu A do punktu B (oszczędność czasu podróży). A to prowadzi do obniżenia kosztów transportu, przede wszystkim poprzez mniejsze zużycie paliwa oraz redukcję w nakładach kapitału i siły roboczej (np. mniejsza amortyzacja taboru ze względu na skrócenie odległości, mniej potrzeba środków transportu na realizację danego zlecenia transportowego). Kolejne czynniki wpływające na to, że przedsiębiorstwa wybierają lokalizację przy węzłach kolejowych to zwiększenie komfortu jazdy, mniejsza liczba wypadków i związany z tym spadek ponoszonych kosztów, wzrost wartości nieruchomości. Te pozytywne implikacje przyczyniają się do zwiększenia bezpieczeństwa i podwyższają jakość świadczonej usługi (podwyższaja poziom obsługi klienta).

Tworzenie sieci dróg o określonym standardzie niweluje bariery rozwojowe danego regionu, zapewnia połączenie z największymi aglomeracjami i zwiększa możliwości zaangażowania kapitału zarówno krajowego, jak i zagranicznego oraz podwyższa mobilność siły

${ }^{28}$ C. Brzeziński, Łódź jako centrum logistyczne transportu - uwarunkowania, materiały z konferencji organizowanej przez Prezydenta Miasta Łodzi „Multimodalne węzły transportu czynnikiem rozwoju regionów", Urząd Miasta Łodzi, marzec 2004, s. 3.

${ }^{29}$ R. Kozłowski, Szanse i zagrożenia dla rozwoju przedsiębiorstw w regionie łódzkim związane z infrastrukturą makrologistyczną, [w:] S. Lachiewicz, I. Staniec (red.), Sytuacja ekonomiczna, organizacyjna i kadrowa dużych organizacji gospodarczych $w$ aglomeracji łódzkiej, Wyd. Media Press, Łódź 2007, s. 9. 
roboczej. Dzięki temu rośnie konkurencyjność polskiej gospodarki na tle innych państw. Dokonuje się to „poprzez budowę spójnej sieci autostrad i dróg ekspresowych w ramach systemu TEN-T"30. Zatem położenie Polski na tle innych krajów stwarza możliwość zapewnienia ciagłości ruchu na trasach tranzytowych w relacjach północ-południe i wschód-zachód. Taką szansę dostał terminal kolejowy w Karsznicach dzięki planowanej drodze ekspresowej S8 łączącej Łódź i Wrocław.

Droga ekspresowa S8 przebiegająca przez aglomerację wrocławską, łódzką i dalej na południowy wschód do Warszawy i Białegostoku początkowo planowana była jako autostrada A8. Jej przekształcenie nastapiło w 2000 r., kiedy zmieniono jej przebieg, tj. przez Piotrków Trybunalski i Bełchatów z pominięciem Łodzi ${ }^{31}$. Jednak wspólne protesty władz wojewódzkich, rządowych i samorządowych wraz z przedstawicielami parlamentu Ziemi Łódzkiej doprowadziły do tego, że przebieg drogi ekspresowej S8 wrócił do swojego pierwotnego planu, czyli WrocławSieradz-Zduńska Wola-Łask-Pabianice-Łódź.

Planowana droga ekspresowa S8 posiada 3 warianty przebiegu: zielony, niebieski i różowy. Na dzień dzisiejszy Regionalny Dyrektor Ochrony Środowiska w Łodzi wydał decyzję, w której określa uwarunkowania środowiskowe dla S8 $\mathrm{w}$ tzw. wariancie zielonym $\mathrm{w}$ połaczeniu z wariantem różowym ${ }^{32}$. Trasa będzie przebiegać na południe od Sieradza (miasto Sieradz będzie posiadać dwa węzły: Sieradz Płd. i Sieradz Wsch.), później wzdłuż drogi krajowej 12, następnie będzie omijać z południowej strony Zduńską Wolę (również dwa węzły: Zduńska Wola i Zduńska Wola Karsznice), Łask (jeden węzeł w okolicach lotniska wojskowego: węzeł Łask Lotnisko i drugi węzeł Łask), Pabianice (węzeł Pabianice Płd.). Od Pabianic do Łodzi S8 z autostradą A1 połączy się w wariancie różowym. Dodatkowo na trasie wyróżniamy w kierunku wschodnim do Łodzi: węzeł Róża w gminie Dobroń, łączący planowaną drogę ekspresową S14 (zachodnia strona Łodzi), węzeł Rzgów w Rzgowie i węzeł Wrocław łączący się z autostradą A1 biegnącą od strony wschodniej Łodzi.

Taki przebieg drogi ekspresowej może się przyczynić do rozwoju regionów znajdujących się w bezpośrednim zasięgu tej drogi. Istniejace lotnisko wojskowe w Łasku, które ma przekształcić się

30 Ministerstwo Rozwoju Regionalnego, Strategia rozwoju kraju 2007-2015, Warszawa 2006 (listopad), s. 34.

${ }^{31}$ Biuro Planowania Przestrzennego Województwa Łódzkiego, Studium tarasowania drogi ekspresowej S-8, Łódź 2004 (czerwiec), s. 4

32 M. Sitarek, Duży krok naprzód, "Siedem dni - Sieradz" 2010, nr 3 (598), styczeń, s. 3. 
w lotnisko cywilno-towarowe typu cargo-mix ${ }^{33}$ w połączeniu z "ekspresówka" umożliwia stworzenie atrakcyjnego miejsca dla potencjalnych inwestorów, głównie budowy centrów logistycznych. Już teraz sa projekty na utworzenie Portu Lotniczego Łódź-Łask na terenie lotniska w Łasku. Projekt kompleksu logistycznego przedstawia rys. 20. Dodatkową funkcja, jaką będzie spełniało lotnisko jest obsługa pasażerów ${ }^{34}$. Droga S8 zapewni wygodny i bezpieczny dojazd osób do celu.

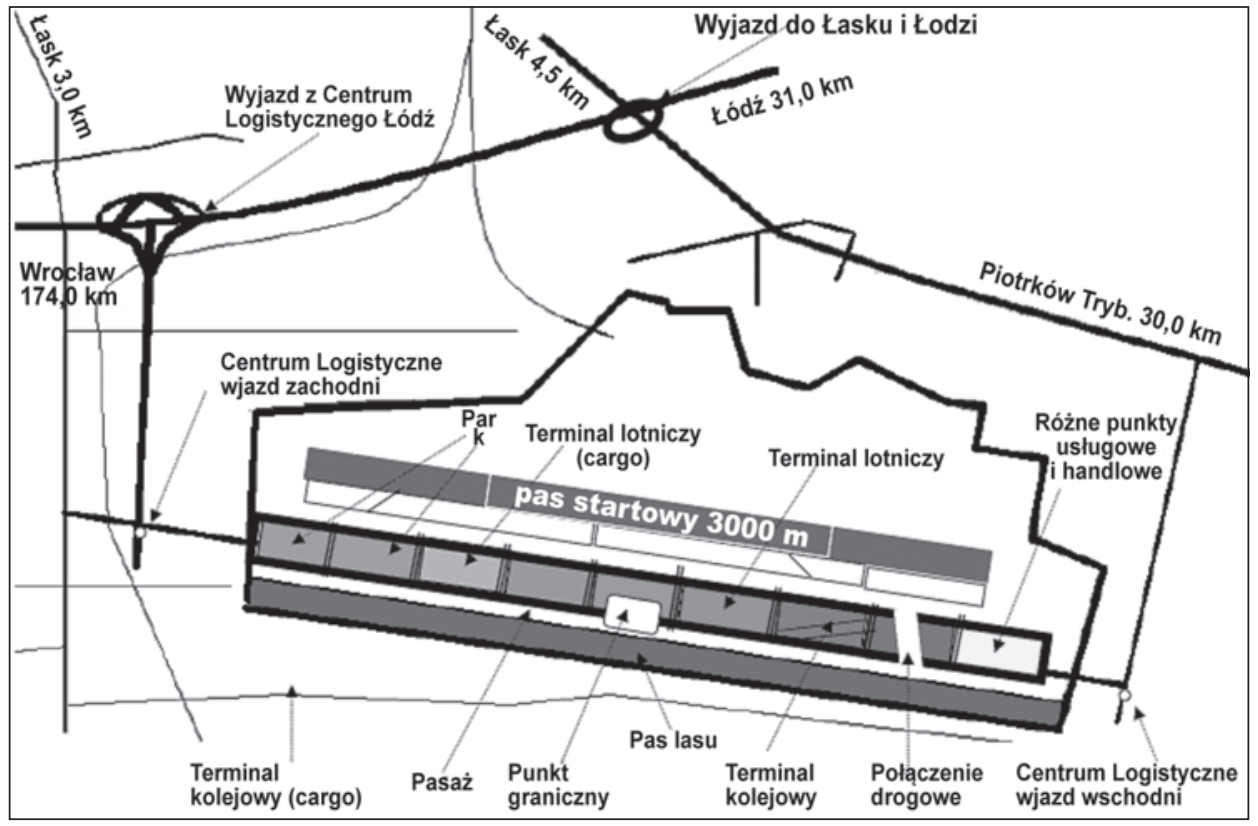

Rysunek 20. Projekt kompleksu logistycznego Łódź-Łask

Źródło: Centrum Zrównoważonego Rozwoju, Kompleks logistyczny Łódź-Łask, prezentacja na www.lodz-sitk.org.pl/news/pliki/IV-2\%20kompleks\%20logistyczny\%20Lask.pdf [z dn. 02.06.2010]

Droga S8 może zapewnić także rozwój terminala kolejowego w Karsznicach pod Zduńską Wola. Przez Karsznice przebiega magistrala kolejowa Śląsk-Porty, wykonująca przewozy towarowe. Bezpośredni dostęp tego terminala kolejowego poprzez węzeł Zduńska Wola (rys. 21) w połączeniu z lotniskiem może przyczynić się do wzrostu znaczenia transportu multimodalnego.

33 http://logistyka.wnp.pl/w-lasku-ma-powstac-cywilne-lotnisko-towarowe-cargo -mix,47076_1_0_0.html [z dn. 11.10.2012].

34 http://forum.gazeta.pl/forum/w,390,77178981,0,_DL_Coraz_blizej_cywilnego _lotniska_pod_Laskiem.html [z dn. 11.10.2012]. 


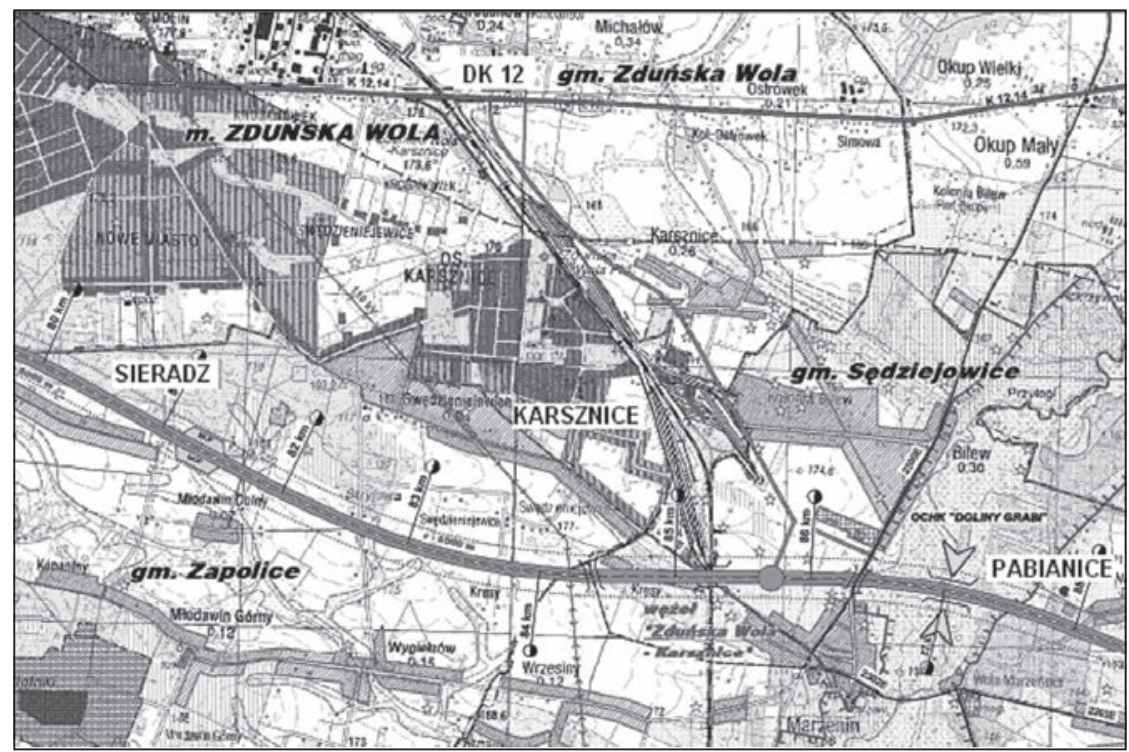

Rysunek 21. Lokalizacja węzła Zduńska Wola Karsznice przy S8

Źródło: opracowanie własne na podstawie: www.uni-logistics.eu/ pliki/plan_szczegolowy_S8_.pdf [z dn. 04.12.2011]

Lokalizacja i wybudowanie drogi ekspresowej S8 stwarza atrakcyjne warunku do tego, by przedsiębiorstwa lokowały się na obszarach znajdujących się przy niej miast. Może przyczynić się to do zmniejszenia bezrobocia dzięki powstawaniu nowych miejsc pracy, głównie przy budowie drogi i modernizacji infrastruktury technicznej. Druga korzyść dotyczy zmniejszenia liczby wypadków drogowych, wynikającego z przejęcia ruchu $z$ ulic miejskich przez drogę ekspresowa ${ }^{35}$. Tym samym na drogach już istniejących zmniejszy się liczba poruszających się pojazdów. Jednocześnie obniży się poziom natężenia hałasu na drodze krajowej 12 przecinającej Pabianice, Łask, Zduńską Wolę i Sieradz. Dodatkowo zostanie wyeliminowany transport autami ciężarowymi, co wpłynie na polepszenie bezpieczeństwa jazdy mieszkańców, a istniejąca infrastruktura nie będzie tak szybko niszczona.

Nowo powstające przedsiębiorstwa przyciągaja coraz więcej nowych klientów, przyczyniają się do ożywienia gospodarczego danego regionu, np. małe gastronomie czy stacje paliw sa budowane przy trasach do obsługi podróżnych. Następuje większe zainteresowanie nieruchomościami. Stare budynki i budowle są remontowane, a później sprzedawane firmom na cele usługowe, biurowe itp.

${ }^{35}$ C. Brzeziński, Łódź jako centrum logistyczne transportu..., s. 5. 
Odpowiednia infrastruktura pobudza do życia gospodarczego. Wpływa na rozwój takich dziedzin, jak informatyka, bankowość, technologia, biznes ${ }^{36}$. Brak drogi $S 8$ zniszczyłby szansę na stworzenie obszarów logistyczno-magazynowych, nie nastapiłoby wykorzystanie potencjału terminala kolejowego w Karsznicach w przewozach multimodalnych, lotnisko w Łasku straciłoby możliwość rozbudowy, a Sieradz nie zyskał obwodnicy. Brak tej drogi zaprzepaściłby wszystkie szanse na szybki rozwój poszczególnych regionów. Na szczęście uzyskanie zgody środowiskowej na budowę S8 i określenie wariantu jej przebiegu „pozwoli ubiegać się o zezwolenia na realizację Inwestycji Drogowej"37, a to już jest ostatni krok do fizycznego podjęcia budowy.

\section{Podsumowanie}

W wyniku analiz przeprowadzonych w niniejszym rozdziale sformułowano następujące wnioski:

- Największy rozwój transportu kolejowego nastapił w okresie międzywojennym.

- Sprawy związane z rynkiem usług kolejowych na terenie Polski reguluja dwie ustawy: ustawa o transporcie kolejowym oraz ustawa o komercjalizacji, restrukturyzacji i prywatyzacji przedsiębiorstwa państwowego Polskie Koleje Państwowe.

- Czynnikiem sprzyjajacym rozwojowi systemu kolejowego był wprowadzony przez rząd polski proces liberalizacji. Dostosowywanie kolei do wymogów Unii Europejskiej odbywało się na zasadach dyrektyw unijnych, konwencji i różnych umów międzynarodowych, tak by istniał jeden wspólny system przewozów kolejowych, zarówno w Polsce, jak i w Europie.

- W transporcie kolejowym nieodzownym składnikiem jest infrastruktura. Jej elementy umożliwiaja poruszanie się oraz przewożenie pasażerów i towarów z jednego miejsca do drugiego w sposób bezpieczny i komfortowy.

- Istniejące na rynku kolejowym firmy wykonuja różne zadania, w zależności to od tego, jakie świadczą usługi. Ich duża liczba powoduje, że staje się ważna jakość świadczonych usług. Im coraz lepsza i dokładniejsza, tym częściej wybierana.

36 Tamże, s. 6.

${ }^{37}$ T. Suchański, S8 - jest decyzja, "Siedem Dni - Zduńska Wola" 2010, nr 3 (598), styczeń, s. 3. 



\section{Wpływ Karsznic na rozwój regionu}

Anita Kącka*

\subsection{Rozwój regionu w oparciu o plany Biura Planowania Przestrzennego Województwa kódzkiego i samorządów lokalnych}

Magistrala Węglowa była kiedyś linią kolejowa wykorzystywana do przewozu węgla kamiennego ze Śląska do Gdyni na terenie Polski. Obecnie jest to linia C-E 65, która biegnie z Gdyni do Pszczyny przez Tczew (w okresie międzywojennym z Bydgoszczy do Gdyni składy towarowe poruszały się przez Maksymilianowo, Szlachtę i Kościerzynę), dalej Bydgoszcz, Inowrocław, Zduńską Wolę Karsznice i Tarnowskie Góry. Linia ta stanowi alternatywę linii E 65 biegnącej przez Warszawę z Gdyni/ Gdańska do Katowic. Linia C-E 65, będąc częścią VI transeuropejskiego korytarza transportowego, biegnie dalej na południe do Brna (Czechy) oraz Ziliny (Słowacja) i służy do przewozów towarowych w relacji północ-południe Europy. Dodatkowo została ona objęta umowa europejską AGTC, tzn. „umową o głównych międzynarodowych liniach kolejowych transportu kombinowanego i obiektach towarzyszących" ${ }^{\prime 1}$. Niestety, aktualny stan techniczny tej linii nie jest zadowalający. Rosnący poziom degradacji infrastruktury doprowadził do ograniczenia prędkości poruszania się składów towarowych, w wyniku czego zmniejszyła się przepustowość tej linii². Efektem tego procesu jest spadek konkurencyjności kolei w stosunku do transportu samochodowego. W związku z tym linia ta nie spełnia europejskich wymogów technicznych, co powoduje, że przewoźnicy zagraniczni nie moga z niej korzystać. By zmienić tę niekorzystna sytuację postanowiono przeprowadzić modernizację tej linii w ramach programów narodowych, dostosowując jej parametry do standardów europejskich.

Plan modernizacji linii C-E 65 jest zgodny z założeniami Polityki transportowej Polski na lata 2001-2015, która zakłada m.in. modernizację linii

* Mgr Anita Kącka - Katedra Logistyki, Wydział Zarządzania Uniwersytetu Łódzkiego, ul. Matejki 22/26, 90-237 Łódź.

${ }^{1}$ www.abc.com.pl/serwis/mp/2004/0050.htm [z dn. 11.10.2012].

2 www.plk-sa.pl/fileadmin/pdf/inestycja/17.09art-przybysz.pdf [z dn. 14.06.2010]. 
kolejowych należących do paneuropejskich korytarzy transportowych ${ }^{3}$. Głównym celem modernizacji całej linii C-E 65 jest zwiększenie prędkości pociągów towarowych do $120 \mathrm{~km} / \mathrm{h}$ oraz dla ruchu pasażerskiego na odcinku Inowrocław-Tczew do $160 \mathrm{~km} / \mathrm{h}^{4}$. Dodatkowo planowana jest przebudowa układów torowych, po których będą mogły poruszać się pociaggi o długości $750 \mathrm{~m}$. Taka modernizacja linii pozwoli Polsce pozostać krajem, który ma znaczący udział w przewozach towarowych koleja.

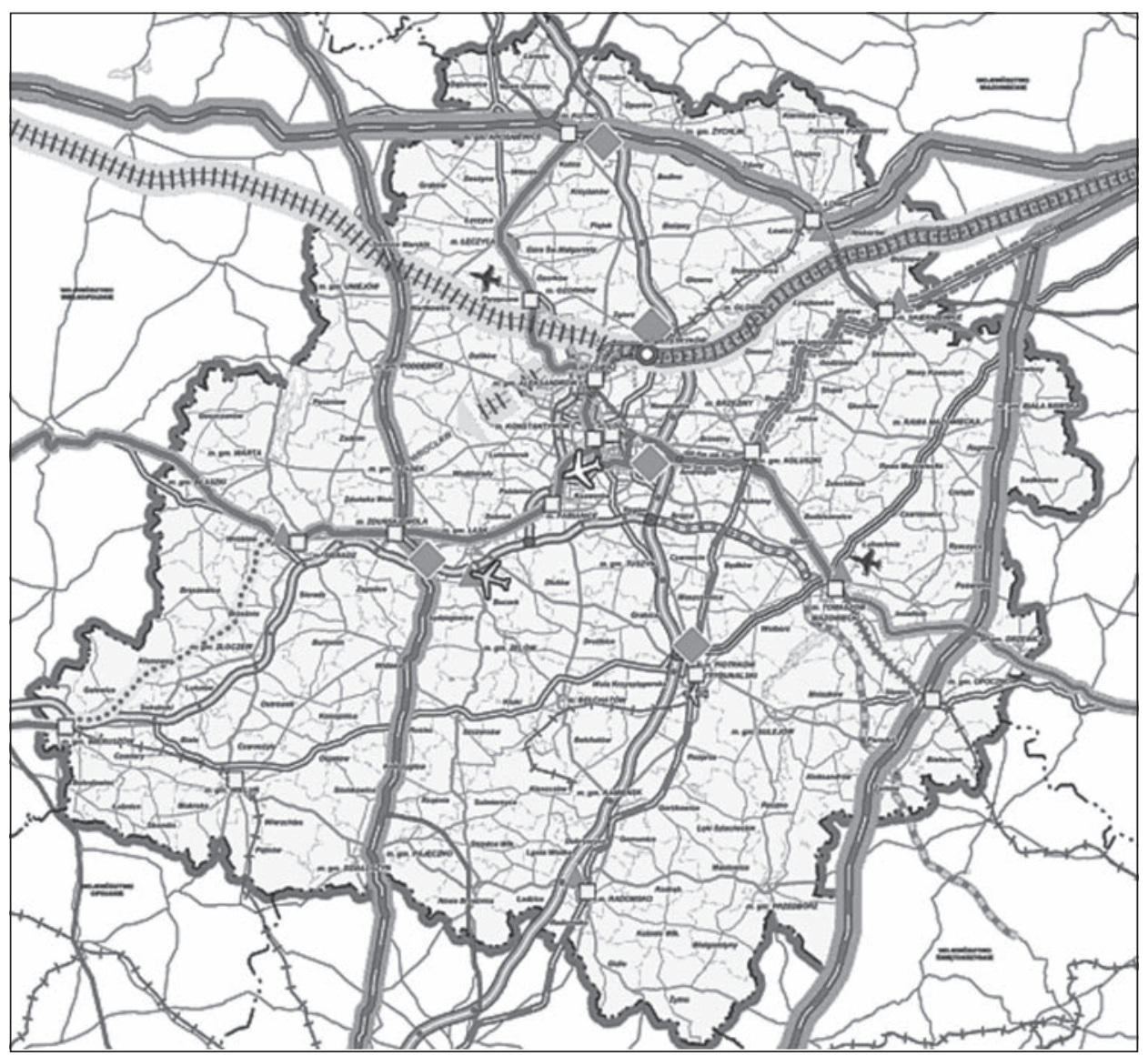

Rysunek 22. Plan kolejowy pokazujący integrację systemów według Biura Planowania Przestrzennego Województwa Łódzkiego

Źródło: http://bppwl.lodzkie.pl/kat/id/51 [z dn. 19.12.2011]

${ }^{3}$ www.cie.gov.pl/www/serce.nsf/0/FB438F2AFC2192CBC1256E830049F445?Open [z dn. 11.10.2012].

${ }^{4}$ www.plk-sa.pl/en/inwestycje/realizacja-inwestycji/projekty-realizowane-z-funduszu-spojnosci/informacje-podstawowe/linie-e-65ce-65/ce65-gdynia-pszczyna.html [z dn. 17.06.2010]. 
W 2005 r. zapadła decyzja, na mocy której w ramach programu TEN-T Polska uzyskała dofinansowanie na wykonanie dokumentacji potrzebnej do przeprowadzenia modernizacji - tzw. studium wykonalności ${ }^{5}$. W ramach studium wykonalności zostanie przeprowadzona analiza stanu infrastruktury i opracowany raport oddziaływania na środowisko.

Biuro Planowania Przestrzennego Województwa Łódzkiego planuje modernizację odcinka linii C-E 65 zgodnie ze wspomnianymi założeniami polityki transportowej. Przebieg linii C-E 65 w województwie Łódzkim przedstawia rys. 22. Modernizacja ma na celu zahamowanie postępującej degradacji infrastruktury kolejowej oraz dostosowywanie paramentów tej linii do standardowych wymogów umowy międzynarodowej AGTC6.

Na mapce widać dwie linie kolejowe o znaczeniu europejskim. Jest to linia C-E 65 przebiegająca przez stację Zduńska Wola Karsznice od strony zachodniej Łodzi, po której składy towarowe maja poruszać się 120 km/h ze Śląska na północ Polski do Gdańska i Gdyni. Druga linia to Centralna Magistrala Węglowa. Linia ta według BPPWŁ ma być modernizowana pierwsza, a później linia C-E 65. Dodatkowo, w północnej części mapki uwidoczniono przebieg szybkiej kolei WarszawaŁódź z możliwością rozbudowy w kierunku Łódź-Wrocław. Gdyby zostato to zrealizowane, nastapiłoby połączenie z tzw. Magistralą Węglową. Połączenie to dałoby szansę dodatkowego rozprowadzania pociągów w kierunku północnym bądź południowym ${ }^{7}$.

Omówiony plan modernizacji linii C-E 65 oraz aktualny przebieg drogi ekspresowej S8 moga przyczynić się do rozbudowy już istniejacego terminala kolejowego w Karsznicach. Występuja dogodne warunki do budowy centrów logistycznych o charakterze regionalnym (zasięg oddziaływania to ok. 50-80 km). Możliwości rozwoju ma też Łask $z$ uwagi na planowane regionalne lotnisko pasażersko-towarowe i drogę ekspresowa S8. Z kolei w Sieradzu moga powstać lokalne centra logistyczne w połączeniu z droga 479 (rys. 23). Wszystkie powstajace centra i ośrodki znajduja się w zasięgu ok. 15-20 km i to silnie wpływa na aktywizację regionów, a w sposób pośredni również na rozwój gospodarki całego województwa8 ${ }^{8}$.

${ }^{5}$ www.plk-inwestycje.pl/index.php?id=136 [z dn. 11.10.2012].

${ }^{6}$ Zarząd Województwa Łódzkiego, Plan Zagospodarowania Przestrzennego Województwa Łódzkiego, http://bppwl.lodzkie.pl/kat/id/51 [z dn. 16.12.2011].

7 Tamże.

8 Tamże. 


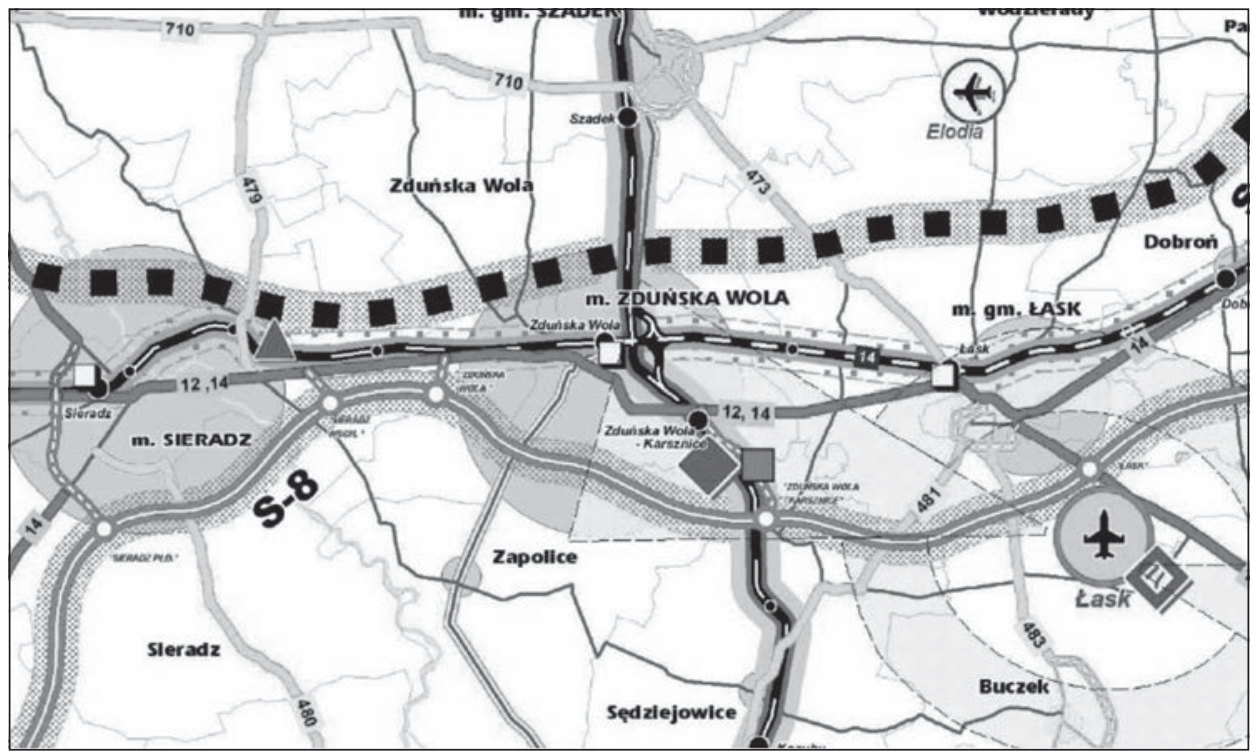

Rysunek 23. Plan zagospodarowania przestrzennego infrastruktury według Biura Planowania Przestrzennego Województwa Łódzkiego

Źródło: http://bppwl.lodzkie.pl/kat/id/51 [z dn. 19.12.2011]

Starostwo powiatowe nie ma planów rozwoju regionu w połączeniu z węzłem karsznickim. Urząd Miasta Zduńska Wola również nie przewiduje planów rozwoju regionu dotyczących bezpośrednio kolei, ale widzi możliwość odrestaurowania skansenu znajdującego się na terenie lokomotywowni. To pozwoli, by stare lokomotywy nie przepadły, a jednocześnie skansen może stać się ośrodkiem turystycznym w Karsznicach.

Pierwszym krokiem Urzędu Miasta było przejęcie od PKP w grudniu 2009 r. prawa użytkowania wieczystego działki wraz z znajdującymi się na niej nieruchomościami, głównie lokomotywami. Miasto uzyskało ten teren za zaległości podatkowe, które PKP była winna magistratowi.

Główne prace będa dotyczyć remontu lokomotyw, nowego zagospodarowania terenu, tak by spełniał wszystkie wymogi umożliwiające turystom zwiedzanie, począwszy od spraw socjalnych, poprzez przebudowę budynku portierni, utwardzenie terenu i postawienie zadaszenia ${ }^{10}$. Mimo że nie udzielono dofinansowania z Ministerstwa Kultury, urzędnicy miasta dalej o to walczą i 26 kwietnia 2010 r. został złożony wniosek do Urzędu

${ }^{9}$ K. Kowalczyk, Kłopoty ze skansenem, „Siedem Dni - Zduńska Wola” 2010, nr 16 (611), kwiecień, s. 5.

10 J. Jeziorska, Jak ma wyglądać skansen lokomotyw w Karsznicach, http://zdunska wola.naszemiasto.pl/artykul/287355,jak-ma-wygladac-skansen-lokomotyw-wkarsznicach,id,t.html [z dn. 17.12.2011]. 
Marszałkowskiego w Łodzi o dofinansowanie remontu 3-4 lokomotyw ${ }^{11}$. W późniejszym czasie maja też być złożone kolejne wnioski na uzyskanie środków finansowych na remont i zagospodarowanie terenu.

\subsection{Napotykane problemy podczas realizacji programu rozwoju}

W sprawie przebiegu drogi ekspresowej S8 od wielu lat toczyły się spory o to, przez które miasta ma ona przebiegać. Na początku wariant przebiegu S8 obejmował Sieradz, Zduńską Wolę, Łódź i taki wariant istniał do 2003 r. Niestety, „w sierpniu 2003 r. kolejne rozporządzenie Rady Ministrów w sprawie ustalenia sieci autostrad i dróg ekspresowych"12 włączyło dodatkowo w drogę S8 Piotrków Trybunalski. Następnie minister infrastruktury w październiku tegoż roku przekazał do Sejmu "Informację o harmonogramie budowy autostrad i dróg ekspresowych na lata 2004-2006 i lata dalsze", w której zawarte mapy wskazywały na inny przebieg S8 niż wcześniej istniejące ${ }^{13}$. S8 miała prowadzić przez Wieluń-Bełchatów-Piotrków Trybunalski. Brak wspólnej jednolitej decyzji o przebiegu S8 doprowadziło do konfliktu, wywołało wiele sporów i protestów, zarówno zwolenników wariantu północnego (ŁódźZduńska Wola-Łask), jak i reprezentantów władz będących za wariantem południowym (Wieluń-Bełchatów-Piotrków Trybunalski).

Sporzadzone przez Biuro Planowania Przestrzennego Województwa Łódzkiego studium wykonalności oraz określenie koncepcji organizacji ruchu $w$ rejonie łódzkim przemawiało za wariantem północnym. Toteż w 2004 r. złożono dokumentację przebiegu S8 w wariancie północnym do traktatu akcesyjnego ${ }^{14}$. Niestety, błąd ludzki polegający na tym, że do zestawu dokumentów dołączono mapkę przedstawiająca przebieg S8 w wariancie południowym zaważył na tym, że do rozwoju transeuropejskich sieci transportowych w Polsce zapisano właśnie ten wariant. Jednak we wszystkich kolejnych dokumentach planistycznych

11 J. Jeziorska, Zduńska Wola bez dofinansowania na remont skansenu lokomotyw w Karsznicach, http://zdunskawola.naszemiasto.pl/artykul/380416,zdunska-wola-bezdofinansowania-na-remont-skansenu, id,t.html [z dn. 17.12.2011].

${ }^{12}$ E. Paturalska-Nowak, Droga ekspresowa S-8 - element strategicznego układu drogowego województwa łódzkiego, prezentacja zamieszczona na: www.uni-logistics.eu/pliki/prezentacja_nt\% 20S-8\%20Ewa\%20Paturalska\%20Nowak\%20.pdf [z dn. 14.06.2010].

13 Tamże.

${ }^{14}$ R. Kozłowski, I. Tomczyk, Problematyka budowy dróg w Polsce na przykładzie drogi ekspresowej S-8 w województwie łódzkim, 2K s.c., Łódź-Sieradz 2009, s. 54. 
tworzonych przez samorządy województwa łódzkiego pojawiały się projekty, w których przebieg drogi ekspresowej występował w wariancie północnym, czyli przez Łódź15, np. w planach Oddziału GDDKiA w Łodzi na lata 2010-2015: „Budowa drogi ekspresowej S8, odcinek węzeł Walichnowy-Łódź (A1)"16. Dodatkowo, w 2006 r. rząd wygospodarował w budżecie blisko $20 \mathrm{mln}$ zł na projekt tej drogi oraz wykup działek na trasie Sieradz-Łódź17. Mimo że znalazły się pieniądze na realizację inwestycji, Komisja Oceny Przedsięwzięć Inwestycyjnych (KOPI) przy Generalnym Dyrektorze Dróg Krajowych i Autostrad przyjęła uchwałę o rozpatrzeniu trzech wariantów przebiegu drogi ekspresowej S8 w województwie łódzkim oraz o uzupełnieniu studium wykonalności S8, nie wziąwszy pod uwagę, że wcześniej rozporządzenie Rady Ministrów określiło przebieg S8 przez Łódź ${ }^{18}$.

Decyzją GDDKiA 7 czerwca 2007 r. postanowiono, że droga krajowa S8 będzie przebiegać w wariancie południowym, tj. Wrocław-Syców-KępnoPiotrków Trybunalski ${ }^{19}$. Jak mówił minister Jerzy Polaczek: „przebieg przez Piotrków dawałby szansę na otrzymanie większego dofinansowania z Unii Europejskiej"20. Decyzja ta przyczyniła się do tego, że Ministerstwo Finansów odebrało Łodzi pieniądze dotychczas przeznaczone na S8 ${ }^{21}$.

Zmiana przebiegu drogi krajowej S8 wzbudziła w mieszkańcach okolic Pabianic, Łasku, Zduńskiej Woli, Sieradza i całego regionu łódzkiego ogromne oburzenie. Efektem były liczne protesty, m.in. zbierano podpisy przeciwko zmianie przebiegu S8, sieradzanie protestowali, blokując drogę Wrocław-Sieradz-Łódź, miały miejsce blokady drogi krajowej nr 14 w Zduńskiej Woli i Łasku, marsz ulicami Łodzi, a później konferencja prasowa i debata dotycząca przebiegu S8 i wiele innych ${ }^{22}$. Wszystkie te akcje miały na celu pokazanie Generalnej Dyrekcji Dróg Krajowych i Autostrad, że rezygnacja z wybudowania S8 w wariancie północnym nie poprawi jakości życia mieszkańców i bezpieczeństwa, nie zmniejszy tranzytu na ulicach miast.

${ }^{15}$ www.uni-logistics.eu/historia_s8.html [z dn. 11.10.2012].

${ }^{16}$ www.gddkia.gov.pl/article/oddzialy/gddkia_lodz/inwestycje_i_remonty//index. php?id_item_tree=85ac3d0e168cca98f3ed7f18ba2a102b [z dn. 14.06.2010].

17 Manifestacja na A2 przeciw przesuwaniu trasy S8 na południe, http://lodz.gazeta. pl/ lodz/1,35136,3509957.html [z dn. 11.10.2012].

${ }^{18}$ www.uni-logistics.eu/historia_s8.html [z dn. 11.10.2012].

19 Tamże.

${ }^{20}$ Nie oddamy S8, http://serwisy.gazeta.pl/wyborcza/1,68586,3512053.html [z dn. 11.10.2012].

${ }^{21}$ Wysyłajmy pocztówki - walczmy o S8!, http://lodz.gazeta.pl/lodz/1,35136, 3602623.html [z dn. 14.12.2011].

${ }^{22}$ R. Kozłowski, I. Tomczyk, Problematyka budowy dróg w Polsce..., s. 77-79. 
Walka o "ekspresówkę”, której towarzyszyły takie hasła, jak: „Rząd ma nas w nosie", "Sieradz chce S-8", "Niech dotrzyma słowa koalicja zarządowa", "Ekspresówka dla Zduńskiej Woli”, doprowadziła do tego, że 31 stycznia 2008 r. GDDKiA przedstawiła ostateczny przebieg S8 - przywrócono wcześniejszy wariant tzw. północny ${ }^{23}$. Ogromne znaczenie miała tu postawa ówczesnego ministra infrastruktury C. Grabarczyka, który uznał, że łódzki przebieg drogi S8 jest uzasadniony ekonomicznie i poparty analizami. Po zatwierdzeniu przez GDDKiA przebiegu S8 przez powiat zduńskowolski i sieradzki pojawił się kolejny problem. Dotyczył on tego, czy trasa ma prowadzić na północ czy na południe od Zduńskiej Woli. Głównie chodziło o teren powiatu łaskiego, przez który przepływa rzeka Grabia24. Sprzeciwiający się wówczas ekolodzy twierdzili, że budowa trasy w wariancie południowym może przyczynić się do zachwiania równowagi środowiska w obrębie tego akwenu. We współpracy z ekologami wypracowano kompromis, który określał mieszany wariant przebiegu trasy. Pojawiły się również protesty mieszkańców Karsznic, które dotyczyły połączenia S8 z droga krajową nr 14. Początkowo zaplanowane połączenie drogi krajowej z "ekspresówką" miało odbywać się ulicą Karsznicka, która biegnie przez osiedle Karsznic wzdłuż torów od strony zachodniej. Obecnie zjazd z S8 ma się znajdować po stronie wschodniej torów.

Uzyskanie decyzji środowiskowej na realizację drogi ekspresowej S8 to jeszcze nie koniec. To dopiero "wierzchołek góry lodowej". Teraz trzeba ubiegać się o zezwolenie na realizację tej inwestycji drogowej, a - jak wiadomo - „oczekiwanie na realizację inwestycji to co najmniej pół roku. Do tego dochodzi jeszcze pozyskiwanie gruntów pod budowę, no i przetargi" - mówi Maciej Zalewski, rzecznik GDDKiA w Łodzi ${ }^{25}$. Do fizycznego rozpoczęcia budowy potrzeba więc jeszcze "tony" dokumentów, a to wpływa na wydłużenie czasu realizacji budowy.

Na przykładzie starań o S8 można wskazać ogólne problemy napotykane podczas wdrażania danego programu rozwoju regionu, głównie przy budowie infrastruktury transportowej. Pierwszym takim problemem jest biurokracja w Polsce. Brakuje odpowiednich ustaw przyspieszających procedury przetargowe; wprowadza się akty prawne, które jedynie hamuja możliwość unowocześniania transportu. Ciągle zmieniające się plany budowy infrastruktury, głównie ze względu na zmiany

23 Tamże, s. 87.

24 T. Suchański, S8 - jest decyzja, "Siedem Dni - Zduńska Wola” 2010, nr 3 (598), styczeń, s. 3.

${ }^{25}$ W. L. Leśniewicz, Na S8 trzeba poczekać, "Dziennik Łódzki”, 18.01.2010, nr 14 (22.410), s. 1 . 
wysokości kosztów, przyczyniają się do tego, że w końcu nie wiadomo co, gdzie i kiedy należy budować oraz czy to się w ogóle opłaca. Również środowisko odgrywa ważną rolę w budowie infrastruktury drogowej. Bez decyzji np. Regionalnego Dyrektora Ochrony Środowiska nie można przystapić do realizacji określonych inwestycji, zatem przy każdym planie budowy drogi trzeba spełniać unormowania w zakresie ochrony środowiska. Nie spełniając tych warunków, jesteśmy narażeni na ciągłe sprzeciwy organizacji ekologicznych, co może opóźniać rozpoczęcie inwestycji. Do tego jeszcze dochodzą trudności związane z wywłaszczeniem mieszkańców z posesji, przez które ma przebiegać dana droga, zarzuty i protesty okolicznych mieszkańców zgłaszane do planu zagospodarowania, zbyt wysoka jakość ziemi. Należy też uwzględnić brak funduszy na inwestycję. To przede wszystkim od ich pozyskania zależy, czy dana inwestycja zostanie zrealizowana. Brak środków w budżecie państwa, w Krajowym Funduszu Drogowym, a przede wszystkim opieszałość w pozyskiwaniu środków z funduszy unijnych przyczynia się do rezygnacji z wdrożenia inwestycji.

Dodatkowym problemem przy finansowaniu inwestycji drogowych są występujące w ostatnich latach powodzie, które niosą ze sobą duże spustoszenia w infrastrukturze komunikacyjnej. Odbudowa zniszczonych dróg krajowych, ulic, pękniętych lub zapadniętych nawierzchni, uszkodzonych mostów pociagga ogromne koszty. Taka sama sytuacja ma miejsce, jeśli chodzi o infrastrukturę kolei - podmyte nasypy, powyginane bądź zerwane tory, zalane stacje. W 2010 r. blisko $300 \mathrm{mln}$ trzeba było wydać na usuwanie zniszczeń dokonanych przez powódź - poinformował rzecznik PKP PLK Krzysztof Łańcucki ${ }^{26}$. Niestety, konieczność przesunięcia środków inwestycyjnych na tereny popowodziowe spowodowała zablokowanie zadań, które miały się już rozpocząć w innych częściach kraju. Brak funduszy może przyspieszyć degradację infrastruktury.

\section{Podsumowanie}

W wyniku analiz przeprowadzonych w niniejszym rozdziale sformułowano następujące wnioski:

- Budowa nowej linii, tzw. Magistrali Węglowej, pełniła rolę „katalizatora", przyczyniając się głównie do rozwoju osiedli kolejarskich, jakim jest osiedle Karsznice i całego dzisiejszego węzła karsznickiego.

${ }^{26}$ http://forsal.pl/artykuly/428741,straty_spowodowane_przez_powodz_w_infrastrukturze_kolejowej_moga_siegnac_300_mln_zl.html [z dn. 11.10.2012]. 
- Węzeł karsznicki znajduje się na jednej z kilku podstawowych i przyszłościowych linii kolejowych w Polsce, która stanowi część VI transeuropejskiego korytarza transportowego.

- By mógł rozwijać się dany region, musza się znaleźć osoby, które będa dbały i walczyły o niego. Tworzenie odpowiednich planów i dażenie do ich realizacji pozostaje w gestii ludzkiej - nic samo nie powstanie.

- Wieloletnia walka o przebieg S8 przybierała różne formy. Protestowały zarówno grupy polityczne, samorządowe, jak i sami mieszkańcy. Te działania dały efekt - droga ekspresowa powstanie w rejonie łódzkim w wariancie północnym.

- Wybudowanie drogi S8 jest bardzo ważne dla mieszkańców Wrocławia, Sieradza, Zduńskiej Woli, Łasku i Łodzi, gdyż daje szansę rozwoju regionów, np. poprzez budowę nowych centrów logistycznych, dogodne warunki do przyciagania nowych inwestorów.

- Modernizacja linii C-E 65 spowoduje skrócenie czasu podróży, a przede wszystkim przyczyni się do ożywienia gospodarczego i społecznego tych regionów, przez które przebiega.

- Linia C-E 65 jest wpisana do paneuropejskiego korytarza transportowego TEN-T, zatem jej modernizacja jest finansowana ze środków unijnych, a to wiąże się ze szczególnym trybem przygotowania wszelkiej dokumentacji i realizacji inwestycji, bo chyba nikt by nie chciał, żeby zabrano nam dofinansowanie $z$ powodu jakiegoś błędnego dokumentu.

- By zapobiec długim okresom realizacji inwestycji, należałoby opracować ułatwienia w procedurach przetargowych, ujednolicone dokumenty, gdyż nierzadko to właśnie one powoduja odwlekanie rozpoczęcia realizacji danej inwestycji. Trzeba też starać się budować tak, by nie wpływało to na konflikty ekologami. 



\section{Wpływ infrastruktury transportowej na Kutno i jego okolice}

Katarzyna Dąbek*

\subsection{Oddziaływanie infrastruktury transportowej na rozwój Łódzkiej Specjalnej Strefy Ekonomicznej Podstrefy Kutno}

Zgodnie z rozporządzeniem Rady Ministrów z dnia 22 sierpnia 2001 r. utworzono w Kutnie Podstrefę Łódzkiej Specjalnej Strefy Ekonomicznej S.A. (ŁSSE).

Przy pisaniu niniejszego rozdziału autorka korzystała z metod badawczych społecznych. Informacje zawarte $w$ dalszej części pochodzą z przeprowadzonego w dniu 15 stycznia 2010 r. wywiadu z przedstawicielem Biura Promocji i Obsługi Inwestorów Urzędu Miasta Kutno - Maciejem Kostrzewa.

W przemysłowej dzielnicy miasta położony jest Kutnowski Park Agro-Przemysłowy (KPAP) utworzony w 1998 r. Obejmuje on tereny ponad 370 ha, na których funkcjonuja małe i średnie firmy (MSP) z krajowym i zagranicznym kapitałem, zatrudniające łącznie ponad 2000 pracowników. W granicach Parku znajduje się ŁSSE o powierzchni 99 ha. Tereny składają się z trzech kompleksów: Odlewnicza, Holenderska, Wschodnia. W 2010 r. zostało wydane rozporządzenie o powiększeniu strefy ekonomicznej do 111 ha (M. Kostrzewa z Urzędu Miasta Kutno powołuje się na Dz.U. z 2010 r., nr 6, poz. 33). Władze Kutna otrzymały $1 \mathrm{mln}$ zł od zarządu Łódzkiej Specjalnej Strefy Ekonomicznej, które zostaną przeznaczone na budowę drogi umożliwiającej komunikację z nowymi terenami. W niedalekiej odległości od KPAP znajduje się międzynarodowy szlak komunikacji drogowej E 30 oraz szlak kolejowy E 20. W odległości ok. $2 \mathrm{~km}$ przebiegać będzie trasa autostrady A1, zaś autostrada A2 znajduje się w odległości ok. $35 \mathrm{~km}$ na południe od Kutna. Obszar posiada sieć bocznic kolejowych wykorzystywanych w celach transportowych przez przedsiębiorstwa. Dostępność komunikacyjna, centralne położenie oraz klimat społeczny należą do atutów

* Mgr Katarzyna Dąbek - Katedra Logistyki, Wydział Zarządzania Uniwersytetu Łódzkiego, ul. Matejki 22/26, 90-237 Łódź. 
przedstawianych potencjalnym inwestorom. Do zalet wyżej wymienionych terenów należy również istnienie:

- ECO Kutno (była Miejska Ciepłownia nr 2), posiadającej możliwość produkcji ciepła technologicznego,

- operatorów energetycznych: PKP Energetyka, Zakłady Energetyczne Energa,

- Grupowej Oczyszczalni Ścieków,

- gazociagu wysokiego ciśnienia,

- ujęć wody,

- Głównego Punktu Zasilania,

- gwarantowanej telefonizacji (Telekomunikacja Polska S.A., Multimedia Polska S.A., magistrale światłowodowe).

Obszar, na którym znajduję się podstrefa, należy do Gminy Miejskiej Kutno.

Inwestor rozpoczynający działalność na obszarze Łódzkiej Specjalnej Strefy Ekonomicznej posiada możliwość korzystania z dogodnych ulg i zwolnień. Największe znaczenie maja m.in.:

- pomoc przy inwestycjach - zwolnienie z podatku dochodowego do $50 \%$ wysokości poniesionych kosztów inwestycyjnych (w przypadku MSP jest to 65\%) lub

- pomoc przy zatrudnieniu - zwolnienie z podatku dochodowego do 50\% wysokości dwuletnich kosztów pracy nowo zatrudnionego pracownika (w przypadku MSP jest to 65\%) oraz

- dogodne oprocentowanie pożyczek na rozpoczęcie działalności,

- podwyższone stawki amortyzacyjne,

- możliwość korzystania z pomocy Urzędu Pracy w sprawach związanych z rekrutacja i szkoleniem nowo zatrudnionych pracowników.

Kutno posiada interesująca ofertę dla inwestorów; nieliczne miasta w Polsce dysponuja podobnymi zasobami. Władze miasta staraja się w pełni wykorzystać zalety regionu, aby stworzyć odpowiednie warunki do inwestowania. Starania kutnian odzwierciedlają następujące nagrody:

- 2005 r. - statuetka w konkursie "Gmina Fair Play",

- 2006 r. - wyróżnienie specjalne "Gmina Fair Play",

- 2007 r. - statuetka w konkursie "Gmina Fair Play", Złota Lokalizacja Biznesu,

- 2008 r. - certyfikat w konkursie "Gmina Fair Play",

- 2009 r. - złota statuetka "Gmina Fair Play”.

Szczególnie istotne dla władz miasta są inwestycje gwarantujące powstanie nowych miejsc pracy dla okolicznej ludności. Pozytywnie odbierani sa również przedsiębiorcy wdrażający nowe technologie i innowacyjne metody zarządzania, dbający równocześnie o zrównoważony rozwój. W dzielnicy przemysłowej Sklęczki pracuje dziś około 3300 osób. 
Urząd Miasta Kutno wział udział w konkursie Moje Wirtualne Miasto i odniósł zwycięstwo w swojej kategorii miast do 50 tys. mieszkańców - Kutno zajęło pierwsze miejsce. Drugie miejsce zajał Kołobrzeg, zaś trzecie Murowana Goślina. Nagroda dla miasta jest wykonanie wirtualnego spaceru po mieście, liczącego 200 panoram, który będzie w przyszłości dostępny na stronie internetowej www.mojewirtualnemiasto.pl. Udział i zwycięstwo w tego rodzaju przedsięwzięciu stanowią ogromną szansę na promocję miasta.

Jednym z przedsiębiorstw znajdujących się na terenie Łódzkiej Specjalnej Strefy Ekonomicznej podstrefy Kutno jest DS Smith Polska. Autorka pracy posłużyła się wywiadem jako narzędziem pozyskiwania wiadomości. Rozmowa została przeprowadzona 3 marca 2010 r. z kierownikiem ds. logistyki Pawłem Tyburą. W dalszej części podrozdziału zostały zawarte informacje pozyskane w trakcie spotkania.

Firma działa na terenie kraju od roku 1971, jest częścią międzynarodowego holdingu DS Smith. Przedsiębiorstwo posiada oddziały Pak Centrum, które zajmują się dystrybucją i obsługa klienta, zlokalizowane w ośmiu miejscach na terenie kraju oraz na Litwie. Zakłady produkcyjne znajdują się w Kutnie, Kielcach i na Słowacji. Centralne biuro DS Smith położone jest na obszarze Kielc.

Do głównych działań firmy należy produkcja różnego rodzaju opakowań, które spełniaja funkcje ochronne, jak również marketingowe. Zasada przedsiębiorstwa brzmi: "Różne opakowania, jeden dostawca”. Wśród szerokiego asortymentu wyróżniamy:

- tektury faliste - arkusze, opakowania,

- palety typu Kay Pal tekturowe,

- tektury kaszerowane, opakowania z tektury kaszerowanej,

- opakowania transportowe i kontenery wielokrotnego użytku z tektur ciężkich,

- opakowania z reprintem,

- plastikowe opakowania do napojów - skrzynki,

- papier komputerowy,

- opakowania z tektur litych i kaszerowanych np. z drukiem offsetowym, złoceniem, tłoczeniem.

Palety typu Kay Pal, wykonane z tektury falistej i tulei kartonowych bez użycia gwoździ, są szczególnie polecane podczas transportu artykułów spożywczych. Ich konstrukcja pozwala na transport za pomoca wózków widłowych, systemów rolkowych oraz na składowanie w regałach. Do zasadniczych zalet palet typu Kay Pal zalicza się: wagę, higieniczność, czystość, możliwość pełnego recyklingu i możliwość nadrukowania kodu paskowego, umożliwiającego monitorowanie palety 
wraz z zawartością. Najważniejszą wadą palet tekturowych jest niska odporność na opady atmosferyczne.

Oddziały handlowe firmy - Pak Centrum - zajmuja się dystrybucją opakowań i materiałów pomocniczych niezbędnych podczas pakowania (m.in. folie, torebki foliowe, taśmy, koperty specjalne oraz palety tekturowe), oferują również usługę VMI - zarządzanie zapasami magazynowymi klienta i dostawy Just in Time, tzn. dokładnie na czas. Za priorytet uważana jest zasada "7W", czyli dostarczenie:

- do właściwego klienta,

- właściwego towaru,

- we właściwe miejsce,

- we właściwej ilości,

- o właściwej jakości,

- po właściwych kosztach,

- we właściwym czasie.

W Kutnie znajduje się zakład produkcyjny DS Smith Polska, którego działalność rozpoczęto w grudniu 2005 r. Decyzja o wyborze lokalizacji została podjęta w kwietniu 2004 r. przez zarząd DS Smith. Na wybór Kutna jako miejsca budowy zakładu produkcyjnego wpłynęły następujące aspekty: duża liczba klientów DS Smith Polska skupiona jest w Warszawie i jej okolicach oraz na terenie Poznania, zaś Kutno położone jest w optymalnej odległości od obydwu tych miast. Dodatkowym atutem przy lokalizacji była dostępność szlaków drogowych, umożliwiająca odpowiednią komunikację. Choć dostawy do klientów są główną rolą Pak Centrum, to również zakłady produkujące wyroby (w Kutnie i Kielcach) zajmuja się obsługa klienta zamawiającego duże ilości produktów.

W Kutnie w ramach zakładu znajduje się magazyn surowców i wyrobów gotowych, w celu zapewnienia ciagłości produkcji. Fabryka w swoim wyposażeniu posiada maszyny przetwórcze i tekturnicę najnowszej generacji. Zakład jest wysoce skomputeryzowany i posiada w pełni zautomatyzowana produkcję. Transport wewnątrz fabryki odbywa się bezobsługowo. W zakładzie wytwarzane są tektury faliste różnego typu oraz opakowania tekturowe z nadrukiem fleksograficznym. Budowa fabryki trwała od grudnia 2004 r., a jej koszt wyniósł 24 mln euro. Przedsiębiorstwo zlokalizowane jest przy ulicy Wschodniej 7 i zajmuje grunt równy 6,6 ha, w tym powierzchnie zabudowane wynosza $28000 \mathrm{~m}^{2}$. Firma obecnie zatrudnia 135 osób, w przyszłości zamierza zwiększyć kadrę pracowniczą do 160 osób. DS Smith Polska wciąż inwestuje w nowe maszyny, do których obsługi zatrudniać będzie kolejne osoby.

Dla zapewnienia wysokiej jakości produkowanych wyrobów w kutnowskiej fabryce został wdrożony system ISO 14001:2000 i ISO 2200:2005. 


\subsection{Oddziaływanie dróg kołowych i szynowych na rozwój miasta i powiatu kutnowskiego}

Obecnie miasto Kutno zajmuje powierzchnię równą 33,6 km², a liczba jego mieszkańców to ok. 47000 osób. Jako stolica powiatu swoim zasięgiem obejmuje 11 gmin, których łączna powierzchnia wynosi 886 km², zaś liczba mieszkańców 102500 osób ${ }^{1}$.

Kutno słynie z baseballu, który jest narodowa, zespołowa gra obywateli Stanów Zjednoczonych. Historia tej amerykańskiej dyscypliny sportowej rozpoczęła się w polskim mieście w roku 1984 za sprawą Kubańczyka mieszkającego w Kutnie - Juana Echevarria, który rozpoczał treningi z młodzieża.

Informacje zawarte $w$ tej części pracy autorka opracowała na podstawie wywiadu przeprowadzonego 25 marca 2010 r. z Beata Kaszuba - Dyrektor Regionu Europy, Afryki, Bliskiego Wschodu Małej Ligi. Spośród szeregu metod badawczych, na potrzeby pracy wybrano badania społeczne.

Kutnowskim baseballem zainteresowała się ambasada amerykańska, popierająca ideę propagowania tego rodzaju sportu w Polsce. Przedstawiciele z USA uczestniczyli w wydarzeniach sportowych, w tym w meczach towarzyskich w Kutnie. Bardzo ważne w dziejach baseballu były wizyty Stanleya Musiala, baseballisty polskiego pochodzenia i biznesmena Edwarda Piszka. Sprzęt sportowy, podarowany przez gości, przyczynił się do dalszego intensywnego rozwoju amerykańskiej dyscypliny wśród mieszkańców Kutna. Powodem wizyty Stanleya Musiala było ukończenie budowy pełnowymiarowego stadionu w Centrum Małej Ligi, który w 2000 r. został nazwany jego imieniem. Baseballista gościł w Kutnie na zaproszenie Małej Ligi, jest on również w zarządzie Fundacji Polskiej Małej Ligii w USA, która zajmuje się zbieraniem funduszy na budowę i działalność Centrum w Kutnie.

W mieście znajduje się Centrum Sportowo-Szkoleniowe Małej Ligi Baseballowej i Softballowej dla Europy, Azji i Afryki, które sfinansowała Amerykańska Mała Liga. Swoim zasięgiem obejmuje 55 państw. Jest największym ośrodkiem baseballowym i softballowym dla dzieci i młodzieży w Europie oraz miejscem rozgrywek 12000 zawodników. Działalność Małej Ligi skupia się na zawodnikach z grupy wiekowej od 5 do 18 lat.

Obecnie istnieja dwa stadiony przeznaczone do gry w baseball i softball, mieszczące po 2000 widzów, jeden pełnowymiarowy stadion

\footnotetext{
${ }^{1}$ http://um.kutno.pl/upload_docs/DOC1Kv4O2.doc [z dn. 29.12.2011].
} 
im. Stana Musiała oraz stadion o pomniejszonych wymiarach, dla dzieci do lat 12, im. Edwarda Piszka. W Kutnie znajduje się także jedno boisko do gry w softball oraz dwa boiska treningowe. W mieście odbywaja się co roku Mistrzostwa Europy, Afryki, Bliskiego Wschodu w różnych kategoriach wiekowych. Rozgrywki otwiera Parada Małej Ligi - z przemarszem drużyn z kilkunastu krajów przez miasto. Zawodnicy z Kutna maja na swoim koncie wiele sukcesów sportowych. W latach 2001-2002 odnieśli zwycięstwo w Mistrzostwach Regionu Europy, Afryki, Bliskiego Wschodu Małej Ligi Baseballowej w kategorii 13-14 lat, dzięki czemu uczestniczyli w Mistrzostwach Świata Małej Ligi w Taylor, Michigan w Stanach Zjednoczonych.

Korzyści, jakie osiąga młodzież grająca w baseball, to m.in. rozwijanie pasji, nauka pracy w zespole, odporność na stres. Gra pokazuje również, jak radzić sobie z ewentualnymi porażkami. Dla miasta ważne są aspekty związane z promocją regionu dzięki owej dyscyplinie sportu. Kutno dzięki rozgrywkom jest odwiedzane przez zawodników i gości z innych państw. O wyborze miasta jako miejsca lokalizacji Małej Ligi zadecydowało centralne położenie oraz odpowiednia infrastruktura transportowa, w tym głównie kolejowa, zapewniająca połączenia komunikacyjne. W latach 1996-2009 w rozgrywkach Małej Ligi w Kutnie brały udział drużyny z następujących państw: Wielkiej Brytanii, Arabii Saudyjskiej, Austrii, Belgii, Białorusi, Bośni i Hercegowiny, Bułgarii, Czech, Francji, Gruzji, Hiszpanii, Holandii, Irlandii, Jordanii, Kuwejtu, Kazachstanu, Kenii, Litwy, Mołdawii, Niemiec, Nigerii, Pakistanu, Republiki Południowej Afryki, Rosji, Rumunii, Słowacji, Słowenii, Szkocji, Szwecji, Turcji, Ukrainy, Włoch, Zjednoczonych Emiratów Arabskich oraz Ugandy.

\subsection{Planowane przez Urząd Miasta Kutno wydatki inwestycyjne}

Władze miasta świadomie podejmuja działania prowadzące do podnoszenia atrakcyjności Kutna dla turystów, jak również dla nowych inwestorów. Dzięki odpowiednio zaplanowanym wydatkom i promocji, miasto staje się interesujące dla zagranicznych i krajowych przedsiębiorców. Działania prowadzone przez władze i firmy lokalne maja na celu rozwój gospodarczy oraz zapewnienie nowych miejsc pracy.

Autorka przeprowadziła analizę materiałów źródłowych w postaci budżetów miasta Kutno na rok 2009 i 2010. Stan bezrobocia na dzień 30 września 2009 r. wynosił 3043 osoby bezrobotne z terenu Kutna 
zarejestrowane w Powiatowym Urzędzie Pracy. W porównaniu z rokiem poprzednim odnotowano wzrost osób bez pracy o 386 mieszkańców miasta (dane z 30 sierpnia 2008 r.). Wzrost bezrobocia jest związany z malejąca liczbą aktywnie działających podmiotów gospodarczych. Ich liczba w roku 2008 (według danych GUS z 30 czerwca 2008 r.) wynosiła 4865, w tym podmiotów działajacych w sektorze: transport, gospodarka magazynowa - 268. Rok 2009 przyniósł niekorzystne zmiany, liczba podmiotów gospodarczych ogółem to 4509, w tym zajmujacych się transportem, gospodarką magazynową - 245. Zmiany w poszczególnych sektorach obrazuje tab. 7.

Tabela 7. Podmioty gospodarcze funkcjonujące na terenie Kutna

\begin{tabular}{|l|c|c|}
\hline \multirow{2}{*}{\multicolumn{1}{|c|}{ Sektory }} & \multicolumn{2}{c|}{ Liczba podmiotów gospodarczych } \\
\cline { 2 - 3 } & 2008 r. & 2009 r. \\
\hline Handel i usługi naprawcze & 1956 & 1732 \\
\hline Obsługa nieruchomości & 692 & 672 \\
\hline Przetwórstwo przemysłowe & 450 & 399 \\
\hline Budownictwo & 365 & 347 \\
\hline $\begin{array}{l}\text { Pozostała działalność usługowa, } \\
\text { komunalna, społeczna i indywidualna }\end{array}$ & 331 & 330 \\
\hline Ochrona zdrowia i opieka społeczna & 303 & 301 \\
\hline $\begin{array}{l}\text { Transport, gospodarka magazynowa } \\
\text { i łączność }\end{array}$ & 268 & 245 \\
\hline Pośrednictwo finansowe & 210 & 191 \\
\hline Edukacja & 109 & 110 \\
\hline Hotele i restauracje & 104 & 105 \\
\hline Rolnictwo, łowiectwo i leśnictwo & 49 & 48 \\
\hline Administracja publiczna & 19 & 19 \\
\hline $\begin{array}{l}\text { Wytwarzanie i zaopatrywanie w energię } \\
\text { elektryczna, gaz, wodę }\end{array}$ & 5 & 6 \\
\hline Górnictwo i kopalnictwo & 4865 & 4 \\
\hline Ogółem & 509 \\
\hline
\end{tabular}

Źródło: opracowano na podstawie budżetu miasta Kutno na rok 2009 oraz budżetu na rok 2010.

Wśród priorytetowych inwestycji miasta na rok 2010 znajduja się m.in.:

- budowa Aquaparku, kręgielni i SPA w kompleksie baseballowym (wartość inwestycji to 16000000 zł), 
- poprawa dostępności komunikacyjnej w przemysłowej dzielnicy miasta poprzez połączenie ulicy Wygoda z ulica A. Mickiewicza (koszt $4112500 \mathrm{zł})$,

- budowa infrastruktury na terenie Łódzkiej Specjalnej Strefy Ekonomicznej: ulica Wschodnia wraz z ulicami przyległymi do niej, przebudowa skrzyżowania, budowa połączenia drogowego do terminalu oraz powstanie kanalizacji deszczowej (koszt 5532000 zł),

- poprawa komunikacji z terenami ŁSSE poprzez połączenie drogi nr 702 z droga krajowa nr 2 (koszt 6364000 zł),

- poprawa stanu dróg miejskich, budowa nowych mieszkań, modernizacja Domu Kultury (wydatek rzędu 7044497 zł), termomodernizacja Szkoły Podstawowej nr 9, budowa obiektów sportowych i inne.

Część inwestycji jest współfinansowana ze środków Unii Europejskiej przez Europejski Fundusz Rozwoju Regionalnego w ramach Regionalnego Programu Operacyjnego Województwa Łódzkiego.

\section{Podsumowanie}

W wyniku analiz przeprowadzonych w niniejszym rozdziale sformułowano następujące wnioski:

- Oferta inwestycyjna, dogodne położenie i dostępność komunikacyjna kutnowskiego regionu przyciaggaja zagraniczne przedsiębiorstwa:

- przedsiębiorstwo Kongskilde Sp. z o.o. powstało poprzez oddolną inicjatywę pracowników zlikwidowanej kutnowskiej firmy Agromet-Kraj,

- szereg inwestycji duńskiego holdingu Kongskilde umożliwia pracę ok. 250 osobom z Kutna i okolic,

- położenie miasta w centrum Polski, w pobliżu Płocka i Włocławka, oraz odpowiednia dostępność szlaków komunikacyjnych zdecydowały o wyborze Kutna jako lokalizacji firmy Nijhof-Wassink,

- przedsiębiorstwo Nijhof-Wassink zatrudnia 120 osób z obszaru kutnowskiego,

- w roku 2010 powstało pierwsze w Kutnie centrum logistyczne,

- firma DS Smith motywuje wybór lokalizacji zakładu centralnym położeniem Kutna oraz dostępnością dogodnych połączeń z Warszawą i Poznaniem,

- przedsiębiorstwo DS Smith inwestuje w park maszynowy,

- ogromne szanse dla regionu (w tym przedsiębiorstw) daje wykorzystywanie środków finansowych z Unii Europejskiej. 
- Władze Kutna rozsądnie inwestują i zarządzaja miastem:

- Łódzka Specjalna Strefa Ekonomiczna Podstrefa Kutno nieustannie się rozwija i poszerza swoja ofertę inwestycyjna,

- Urząd Miasta Kutno aktywnie promuje miasto na arenie krajowej i międzynarodowej,

- władze kutnowskie wykorzystująśrodki finansowe z Unii Europejskiej,

- istnieje Mała Liga Baseballowa jako atrakcja i ewenement na skalę międzynarodowa,

- kryzys gospodarczy przyczynił się do wzrostu bezrobocia oraz spadku liczby podmiotów prowadzących działalność gospodarczą.

Na koniec warto przytoczyć słowa rektora Akademii Krakowskiej żyjacego w latach 1743-1824, ks. Sebastiana Hrabiego Sierakowskiego: "Drogi publiczne w kraju tem sa, co kanały w ciele żyjącym, któremi soki utrzymuja jego życie, a rozchodząc się do ostatnich części ciała, zdrowie i czerstwość jego utrzymują. Drogi publiczne jak są znakiem potęgi, handlu, a zatem bogactw i rządu dobrego krajowego, tak sa oraz środkiem do ich utrzymania"2. Słowa te umieszczone zostały przed wejściem do jedynego w Polsce Muzeum Drogownictwa, znajdującego się w Szczucinie.

2 www.gddkia.gov.pl/viewattach.php/.../e0f04c1f0d6dca23332b13e2d59ad486 [z dn. 21.04.2010]. 



\section{Metro w Londynie jako modelowy przykład rozwiązania transportu miejskiego}

Magdalena Drzewoszewska*

\subsection{Historia powstania i rozwoju systemu kolei podziemnych w Londynie}

Na początku XIX wieku w Londynie mieszkało około miliona ludzi. W ciagu tylko jednego wieku populacja wzrosła do 4,5 mln w samym mieście, a na przedmieściach żyło jeszcze około $2 \mathrm{mln}^{1}$. Powodem tak ogromnego wzrostu był niewątpliwie sukcesywnie rozwijany system transportu miejskiego. Rewolucja w transporcie ludzi nastapiła, kiedy kolej parowa zaczęła obsługiwać przewozy pasażerskie. Na początku połączenia kolejowe były tworzone, aby ułatwić długie podróże i połaczyć Londyn z reszta kraju. Stacje były budowane w zbyt wielkiej odległości od miasta, aby ułatwić mieszkańcom codzienne podróże do pracy. Więcej stacji w pobliżu Londynu wybudowano w latach 50. XIX wieku. Około $10 \%$ podróżujących wcześniej omnibusami lub pieszo zmieniło środek transportu na kolej. W latach 60. XIX wieku zarządcy spółek kolejowych dostali pozwolenie na rozbudowę linii na terenie całego miasta. Do 1900 r. Londyn posiadał już 15 stacji. Podczas budowy około 100 tys. mieszkańców zostało wysiedlonych ze swoich domów, aby zrobić miejsce na nową infrastrukturę3.

Pierwsza linia metra została zaprojektowana, aby dowozić pasażerów ze stacji kolejowych do samego centrum miasta. Pomysł, aby budować ja pod główna droga zapobiegał zniszczeniom posesji. Do realizacji projektu została powołana The Metropolitan Railway Company w 1854 r. Prace ruszyły w 1860 r. i były prowadzone metodą odkryw-

* Mgr Magdalena Drzewoszewska - Katedra Logistyki, Wydział Zarządzania Uniwersytetu Łódzkiego, ul. Matejki 22/26, 90-237 Łódź.

${ }^{1}$ www.Itmcollection.org/museum/gallery/gallery_sub.html?IXgallery=CGP.020.010 [z dn. 11.10.2012].

2 Duży kryty pojazd konny, używany dawniej jako środek komunikacji.

${ }^{3}$ http://www.Itmcollection.org/museum/gallery/gallery_sub.html?IXgallery $=$ CGP.020.230\&IXfilter $=$ CGP.020.230.005 29.11.09 [z dn. 15.12.2011]. 
kowa, która jest stosowana przy budowie płytkich tuneli. Podstawowe prace przy tego rodzaju budowie to wykonanie wykopów, obudowy, a następnie zasypanie gruntem ${ }^{4}$. Tunel budowało ręcznie około 2000 niewykwalifikowanych robotników. Inżynierowie nie dysponowali żadnymi planami gruntów, w których kopali. Jednak mimo problemów, prace zostały ukończone, a tunele oddane do użytku. 10 stycznia 1863 r. spółka Metropolitan Railway otworzyła pierwszą na świecie linię podziemnej kolei, która pierwszego dnia funkcjonowania przewiozła 30 tys. pasażerów ${ }^{5}$. W 1864 r. do linii Metropolitan zostało dobudowane połączenie z Hammersmith, które w późniejszym czasie przekształciło się w osobną linię Hammersmith \& City. Sukces pierwszej inwestycji doprowadził do następnej. W 1868 r. ruszyła pierwsza część linii Metropolitan District Railway z South Kensington do Westminster (obecnie jest częścią linii District i Circle). Dwie istniejące linie były zarządzane przez rywali: J. Forbesa i E. Watkina. Ich nieustanny konflikt spowodował, że kolejna z linii Circle, która miała połączyć obie już istniejące jako linia obwodowa, powstawała 20 lat. W 1884 r., kiedy została ukończona, jeden z przedsiębiorców obsługiwał pociągi jeżdżące zgodnie z kierunkiem wskazówek zegara, a drugi w stronę przeciwna. Firmy odmówiły sprzedaży biletów na linie konkurenta, co powodowało duże niedogodności i zbędne wydatki dla pasażerów, a także opóźniły znacznie budowę połączeń.

Linia Circle była ostatnia, która powstała z wykorzystaniem metody odkrywkowej, drogiej i uciążliwej, gdyż wprowadzała chaos w mieście, wymagając zamykania ulic i ograniczając dostęp do obiektów. W celu budowy tuneli zaczęto stosować metodę tarczy. M. I. Brunel wynalazł "tarcze", czyli kilka rur prostokątnych umieszczonych obok siebie, o wymiarach budowanego tunelu. Była ona wykorzystywana do zabezpieczenia przodka i wraz z postępem przesuwana do przodu. Za nią wykonywana była obudowa ostateczna z żeliwnych rur ${ }^{6}$. Dzięki tej metodzie było możliwe drążenie tuneli nawet na głębokości $30 \mathrm{~m}$. Ten sposób budowy dał poczatek charakterystycznej dla londyńskiego metra nazwie tube (z ang. rura). Aby stacje na takich głębokościach mogły funkcjonować, trzeba było wymyślić sposób przewożenia ludzi w górę i w dół. Na początku używano wind. Rewolucją stały się schody ruchome, pierwszy raz zainstalowane w 1911 r. na stacji Earl's Court. Największym problemem w podziemnych tunelach były ogromne ilości dymu i pary. Próbowano

${ }^{4}$ K. Furtak, M. Kędracki, Podstawy budowy tuneli, Wyd. Politechniki Krakowskiej, Kraków 2005, s. 18.

${ }^{5}$ www.timeout.com/london/big-smoke/blog/2814/london-undergrounds-history. html [z dn. 11.10.2012].

${ }^{6}$ K. Furtak, M. Kędracki, Podstawy budowy tuneli, s. 43. 
sobie z tym poradzić na wiele sposobów, m.in. zamontowano rurki, które przekształcały parę w gorąca wodę; palono koksem, gdyż wytwarzał mniej dymu niż węgiel, jednak żadna z tych metod nie spełniała wymogów technologii potrzebnej w głębokich tunelach. Na początku planowano użycie systemu kabli, który z sukcesem został zastosowany w kolejce naziemnej w San Francisco. Ostateczne zdecydowano się jednak na nowinkę technologiczną o wysokim ryzyku - energię elektryczna? ${ }^{7}$ Pierwsza linia elektryczna została uruchomiona 18 grudnia 1890 r. przez spółkę City \& South London Railway. Pociągi kursowały na odcinku o długości 5,25 km od King William Street w centralnym Londynie przez tunel pod Tamiza do Stockwell (dzisiejsza linia Northern) ${ }^{8}$. Ten ogromny przełom spowodował rozpoczęcie wielu nowych inwestycji. Były one mocno wspierane przez miasto stojące przed zadaniem poradzenia sobie $z$ coraz większym zatoczeniem ulic. Jeszcze $w$ tym samym roku aprobatę zyskały projekty dzisiejszych linii Central, Bakerloo, Piccadilly, Waterloo \& City i Northern. Pieniądze pochodziły od prywatnych inwestorów i - niestety - często się kończyły, dlatego prace trwały zwykle dłużej niż planowano. Linia Waterloo \& City została ukończona w 1898 r. i była druga w mieście linią w głębokim tunelu. Jej budowa była mocno popierana przez London and South Western Railway, jako że ich pociagi dojeżdżały do stacji na Waterloo i chcieli, aby pasażerowie mieli bezpośrednie połączenie kolejowe z miastem.

Na początku XX wieku większość biletów było kupowanych na pojedyncze trasy w kasach na stacji. Była tylko jedna kategoria miejsc, więc wybór odpowiedniego biletu nie był skomplikowany. Istniały bilety okresowe, a do roku 1920 na najbardziej ruchliwych stacjach pojawiły się automaty biletowe. Jednak sprawdzanie biletów odbywało się ręcznie aż do 1990 r., kiedy wprowadzono w pełni automatyczny system.

W roku 1900 książę Walii otworzył kolejną linię wybudowana przez Central London Railway, która kursowała z Shepherd's Bush do Bank (teraz jest to cześć Central Line). W 1902 r. z inicjatywy amerykańskiego inwestora Charlesa Yerkesa powstała spółka Underground Electric Railway Company of London (UERC). Ludzie, którzy ją utworzyli, zdołali do czasu rozpoczęcia II wojny światowej przejąć i złączyć w grupę wszystkie linie metra oprócz Metropolitan. Zaraz po jej utworzeniu zajęli się trzema nowymi projektami: budową linii Bakerloo, Piccadilly i Hampstead oraz elektryfikacja District Line. Do roku 1907 zostały

${ }^{7}$ www.Itmcollection.org/museum/gallery/gallery_sub.html?IXgallery=CGP.050.030 [z dn. 11.10.2012].

${ }^{8}$ www.tfl.gov.uk/corporate/modesoftransport/londonunderground/keyfacts/13174. aspx [z dn. 11.10.2012]. 
zakończone wszystkie rozpoczęte inwestycje, a stare linie otrzymały pociagi napędzane energia elektryczna. Londyn posiadał sieć metra składająca się z 8 elektrycznych linii. W tym samym roku, ukończywszy swój trzeci projekt, spółka UERC była na skraju bankructwa. Na szczęście pojawił się Albert Stanley (przyszły Lord Ashfield), który przejał kontrolę i wyprowadził firmę z długów. To jego umiejętności polityczne i ekonomiczne pozwoliły zjednoczyć transport w mieście9. W roku 1906 do spółki dołączył Frank Pick. Dzięki niemu zarządzanie siecią stało się bardziej uporządkowane, a marka, jaką stało się londyńskie metro, zaczęła być rozpoznawana na całym świecie. Dobry system transportowy oznacza, że pasażer może przemieszczać się w określone przez siebie miejsca szybko i sprawnie. W 1933 r. Harry Beck stworzył mapę sieci metra tak prosta w użytkowaniu, że schemat jej wykonania został w późniejszych latach skopiowany praktycznie przez każde miasto. Jako że każda firma potrzebuje znaku rozpoznawczego, w 1913 r. świat po raz pierwszy zobaczył czerwone kółko jako znak londyńskiego metra, które jest jednym z najbardziej rozpoznawalnych symboli na świecie.

W 1933 r. UERC i Metropolitan Railway weszły w skład nowo powstałej instytucji London Passenger Transport Board, odpowiedzialnej za kolej, autobusy, tramwaje, trolejbusy i taksówki.

Okres II wojny światowej oznaczał dla transportu w Londynie czas przestoju i zniszczeń, jednak pracownicy i zarządcy robili wszystko, aby utrzymać komunikację, a metro stało się symbolem przetrwania. Podczas jednej nocy system metra został uszkodzony przez bomby w 20 miejscach. Ludzie pracowali 24 godziny na dobę, aby naprawić zniszczenia. Kiedy w 1940 r. rozpoczęło się bombardowanie, ludzie zaczęli uciekać na podziemne stacje, szukając schronienia. Pracownicy nie byli na to przygotowani, jednak szybko udało im się zorganizować. Pojawiły się wejściówki, łóżka piętrowe, pomoc medyczna, chemiczne toalety i posiłki. Przez kolejne dni bombardowania stacje co noc przeistaczały się w schrony. Były używane również do przechowywania cennych zbiorów, m.in. z British Museum (Muzeum Brytyjskie). Wojna skończyła się w maju 1945 r., a transport w mieście przez cały ten czas zdołał funkcjonować. Największym problemem były ogromne zniszczenia infrastruktury. Stacje, zajezdnie i garaże mocno ucierpiały w wyniku nalotów. Po wojnie London Transport oraz cztery najważniejsze spółki kolejowe zostały upaństwowione i znalazły się bezpośrednio pod władzą rządu. Uważano, że przyniesie to znaczna poprawę sytuacji w transporcie. Tak się jednak nie stało ze względu na bardzo małą ilość inwestowanych środków.

${ }^{9}$ www.Itmcollection.org/museum/gallery/gallery_sub.html? IXgallery $=$ CGP.050.070\&IXfilter $=$ CGP.050.070.020 02.01.2010 [z dn. 15.11.2011]. 
W 1969 r. królowa otworzyła kolejna linię metra Victoria, a w 1977 r. trzy stacje linii Piccadilly na lotnisku Heathrow. Książę Walii w 1979 r. uczestniczył w otwarciu nowej linii Jubilee. Na stacji King's Cross w 1987 r. wybuchł pożar, w którym zginęło 31 osób. Najbardziej prawdopodobna przyczyna był niedopałek papierosa rzucony $w$ windzie, mimo że palenie na stacjach podziemnych oraz w pociagach zostało zabronione kilka lat wcześniej po pożarze na stacji Oxford Circus. Po tym wypadku zostały wprowadzone nowe przepisy w zakresie bezpieczeństwa i przeciwpożarowe. W 1999 r. rozpoczęła się restrukturyzacja spółki London Underground, która doprowadziła w 2003 r. do połączenia się z Transport for London oraz powstania partnerstwa publiczno-prawnego.

\subsection{System zarządzania i charakterystyka sieci metra}

W roku 2007 liczba pasażerów przewieziona transportem publicznym w Londynie wyniosła 3,275 mln, z czego 1,072 mln przewozów zostało wykonanych za pomoca sieci metra, co daje $32 \%$ udział ${ }^{10}$. Największą ilość przewozów publicznych świadczą autobusy - powodem może być ich większa dostępność oraz to, że bilet okresowy na przejazdy jest tańszy. Jednak pasażer, który chce pokonać znaczną odległość w krótkim czasie z pewnościa wybierze metro. Ten rodzaj transportu jest szczególnie ważny w obsłudze podróży do strefy centralnej miasta. W 2007 r. liczba osób wjeżdżających do centrum podczas porannych godzin szczytu (7:00-10:00) wyniosła 1,14 mln, z czego 502 tys. dostało się tam przy wykorzystaniu publicznego transportu szynowego (metro, kolej). Na wybór środka transportu bardzo duży wpływ ma obszar zamieszkania. Im dalej od centrum, tym mniejszy udział transportu publicznego w przewozach, a co za tym idzie również metra. Wpływa na to również gęstość sieci, która w centrum jest największa. Kolej najlepiej sprawdza się na długich trasach, gdyż porusza się odseparowanymi od reszty infrastruktury torami, jest zatem ważnym środkiem transportu dla pasażerów podróżujących bezpośrednio z obrzeży miasta do centrum.

Organem odpowiedzialnym za zarządzanie transportem na terenie całej stolicy jest Transport for London (TfL), który został utworzony w 2000 r. Jest to spółka podlegająca pod lokalną władzę. Podstawowymi zadaniami jednostki jest wprowadzanie w życie Mayor's Transport Strategy for London (ang. transportowa strategia burmistrza w Londynie) oraz zarządzanie systemem transportu na terenie miasta.

${ }^{10}$ www.tfl.gov.uk/assets/downloads/corporate/Travel-in-London-report-1.pdf [z dn. 11.10.2012]. 
London Underground jest częścią TfL odpowiedzialną za system londyńskiego metra. Zostało utworzone w 1985 r., ale jego początki sięgaja roku 1863, kiedy uruchomiono pierwszą na świecie podziemną kolej ${ }^{11}$. Instytucja ta jest częścią TfL od lipca 2003 r. Zajmuje się kursowaniem pociągów, kontrolowaniem i utrzymywaniem stacji oraz punktów kontrolnych, dbaniem o bezpieczeństwo w pociaggach i na stacjach, a także zbieraniem i zabezpieczaniem wszystkich opłat transportowych. Obecnie London Underground jest odpowiedzialna za 8 z 11 linii metra. Przewozi ponad miliard pasażerów rocznie, dla porównania - tyle samo pasażerów przewozi cała kolej narodowa (National Rail) ${ }^{12}$. Wizją firmy jest dostarczenie światowej klasy metra dla światowej klasy miasta. Aktualnym wyzwaniem jest utrzymanie ruchu pociagów w czasie, kiedy trwa największa od 60 lat przebudowa infrastruktury systemu. W związku z latami zaniedbań trzeba było uruchomić ogromny program inwestycyjny, który ma zwiększyć przepustowość systemu oraz sprostać wymaganiom klientów. Nie bez znaczenia były także Igrzyska Olimpijskie odbywajace się w stolicy Wielkiej Brytanii w 2012 r. Dla miasta oznaczało to konieczność poradzenia sobie z transportem ogromnej liczby ludzi.

Linie Piccadilly, Northern i Jubilee sa na mocy umowy o Partnerstwie Publiczno-Prywatnym (PPP) pod opieką Tube Lines (TL). Firma podpisała z London Underground 30-letnia umowę na utrzymywanie i ulepszanie całej infrastruktury podlegających im linii (trakcje, sygnalizacja, stacje, mosty, nasypy, pociągi, tunele). London Underground odpowiada za wszystkie usługi związane z obsługa klientów (kursowanie linii, bilety, zamykanie i otwieranie stacji, rozkłady jazdy). Priorytety działalności wynikaja ze strategii transportowej miasta i muszą być przez TL wypełniane. Tak długa perspektywa trwania kontraktu pozwala firmie na długookresowe korzyści wynikające ze współpracy z dostawcami i podwykonawcami.

Od 2003 r. w mieście funkcjonuje wprowadzona przez TfL elektroniczna karta miejska o nazwie Oyster Card. Można na nia wykupić bilet okresowy na metro, tzw. Travelcard, a także bilet okresowy na autobusy i tramwaje Bus \& Tram Pass ${ }^{13}$. Posiadanie okresowego biletu Travelcard upoważnia do korzystania $z^{14}$ :

- metra, kolejki DLR i London Overground w wykupionej strefie, - sieci autobusowej,

${ }^{11}$ www.tfl.gov.uk/assets/downloads/corporate/london-underground-factsheet-july-2009.pdf [z dn. 29.12.2009].

12 www.tfl.gov.uk/corporate/modesoftransport/1574.aspx [z dn. 11.10.2012].

${ }^{13}$ G. Dydkowski, Adaptacja cen do warunków integracji, [w:] R. Tomanka (red.), Ceny transportu miejskiego w Europie, Wyd. Akademii Ekonomicznej w Katowicach, Katowice 2007, s. 104-105.

${ }^{14}$ www.tfl.gov.uk/tickets/faresandtickets/1059.aspx [z dn. 20.11.2011]. 
- sieci tramwajowej (jeśli Travelcard obejmuje strefy 3, 4, 5 lub 6), - sieci National Rail na terenie Londynu.

Kartę można również zasilić gotówką i dokonywać płatności w różnych rodzajach transportu w trybie Pre-Pay. Szczególnie wygodne dla podróżujących $w$ różnych strefach jest to, że na jednej karcie moga mieć trzy bilety okresowe oraz funkcje biletu Pre-Pay jednocześnie. Największą zaletą funkcji Pre-Pay jest to, że jest tańsza i wygodniejsza od tradycyjnych papierowych biletów, a gotówka przechowywana na karcie nigdy nie straci ważności. Używając funkcji przedpłaty, podróżny korzysta jeszcze z daily price capping, to znaczy, że za cały dzień podróżowania system nie naliczy większej kwoty niż pasażer zapłaciłby za tradycyjny jednodniowy bilet. Bilet elektroniczny można kupić na stacjach metra, przez Internet oraz w London Travel Information Center. Poruszając się tramwajami lub autobusami, kartę trzeba przyłożyć żółtego czytnika na początku podróży. W metrze, kolejce DLR, London Overground oraz National Rail - na początku i na końcu trasy.

Sieć londyńskiego metra obejmuje 11 linii o łącznej długości 402 km, z czego 45\% znajduje się w głębokich tunelach. W skład sieci wchodzi 260 stacji. Najdłuższa odległość miedzy stacjami to 6,26 km, a najkrótsza $0,26 \mathrm{~km}$. Średnia prędkość pociągów to $33 \mathrm{~km} / \mathrm{h}$ łącznie $z$ postojami na stacjach. W centrum Londynu pociągi nie moga rozpędzić się do większych prędkości niż 20-27 km/h, ponieważ odległości między stacjami są zbyt małe. Ważnym elementem są też windy i ruchome schody. Na wszystkich stacjach zamontowane sa 122 windy i 412 ruchomych schodów. Najdłuższe ruchome schody znajdują się na stacji Angel, mają długość $60 \mathrm{~m}$ i wwożą pasażerów na wysokość 27,5 m w pionie. Najkrótsze są zainstalowane na stacji Stratford, wysokość wznoszenia 4,1 m. Najbardziej zatłoczoną stacja w godzinach porannych jest Waterloo. Podczas trzech godzin porannego "oblężenia" wchodzi na nia ponad 51 tys. osób. Natomiast w skali roku najbardziej zatłoczona stacja to Victoria z $76 \mathrm{mln}$ podróżnych ${ }^{15}$. Poniżej znajduje się krótka charakterystyka każdej z 11 linii metra.

Waterloo \& City to najkrótsza linia $(2,4 \mathrm{~km})$ i nieobsługująca żadnych stacji przesiadkowych. Została stworzona, aby połączyć stację kolejowa na Waterloo z miastem. Cała trasa znajduje się w tunelu i jest odizolowana od innych. Cztery czterowagonowe maszyny o nazwie 1992 Stock potrzebne są do obsługi podczas godzin szczytu. Od czasu przejęcia w 1994 r. od British Rail linia znajduje się pod zarządem London Underground.

${ }^{15}$ www.tfl.gov.uk/corporate/modesoftransport/londonunderground/1608.aspx [z dn. 11.10.2012]. 
Tabela 8. Długość linii metra, liczba obsługiwanych stacji i zajezdnie

\begin{tabular}{|l|r|r|l|}
\hline \multicolumn{1}{|c|}{ Nazwa } & $\begin{array}{c}\text { Długość linii } \\
\text { w km }\end{array}$ & $\begin{array}{c}\text { Liczba } \\
\text { obsługiwanych } \\
\text { stacji }\end{array}$ & \multicolumn{1}{|c|}{ Zajezdnie } \\
\hline Waterloo \& City Line & 2,4 & 0 & Waterloo \\
\hline Victoria Line & 21,0 & 25 & Sorthumberland Park \\
\hline Bakerloo Line & 26,0 & 19 (28 w godz. & Hammersmith \\
\hline $\begin{array}{l}\text { Hammersmith } \\
\text { \& City Line }\end{array}$ & 27,0 & 27 & Hammersmith \\
\hline Circle Line & 36,0 & 27 & $\begin{array}{l}\text { Neasden, Stratford } \\
\text { Market }\end{array}$ \\
\hline Jubilee Line & 58,0 & 50 & $\begin{array}{l}\text { Golders Green, } \\
\text { Morden }\end{array}$ \\
\hline Northern Line & 64,0 & 60 & $\begin{array}{l}\text { Ealing Common, } \\
\text { Upminster }\end{array}$ \\
\hline District Line & 67,0 & 34 & Neasden \\
\hline Metropolitan Line & 71,0 & 52 & $\begin{array}{l}\text { Northfields, } \\
\text { Cockfosters }\end{array}$ \\
\hline Piccadilly Line & 74,0 & 49 & $\begin{array}{l}\text { West Ruislip, Hainault, } \\
\text { White City }\end{array}$ \\
\hline Central Line & & & \\
\hline
\end{tabular}

Źródło: opracowanie własne na podstawie www.tfl.gov.uk/corporate/modesoftransport/ londonunderground/1608.aspx [z dnia 02.12.2011].

Trasa linii Victoria przebiega z północno-wschodniego Londynu przez centrum na południe miasta. Była pierwszą automatyczną linią pasażerską na świecie, przystosowaną do sterowania w systemie ATO (Automatic Train Operator). Tryb ten umożliwia jazdę, w której rola obsługującego ogranicza się do nadzoru i zamykania drzwi ${ }^{16}$. Kiedy motorniczy naciśnie przycisk, pociąg jedzie sam aż do następnej stacji. Jest to możliwe dzięki sygnałom wysyłanym do przez sieć trakcyjna. Długość połączenia to $27 \mathrm{~km}$, a trasa znajduje się całkowicie pod ziemia. Jej przejechanie zajmuje 32 min. W godzinach szczytu obsługiwana jest przez 37 ośmiowagonowych pociagów o nazwie 1967 Stock.

Dwudziestotrzykilometrowa linia Bakerloo kursuje po torach będacych własnością kolei narodowej (National Rail). Trasa prowadzi z północno-zachodniego Londynu przez centrum na południe. Obsługuje 25 stacji siedmiowagonowymi maszynami o nazwie 1972 Stock.

16 J. Wesołowski, Ukształtowanie kolejowego węzła łódzkiego i możliwości jego włączenia w system kolei dużych prędkości, "Technika Transportu Szynowego" 2005, nr 12 (grudzień), s. 97-124. 
Linia Hammersmith \& City przebiega z zachodu na wschód miasta. Jej długość to $25,5 \mathrm{~km}$, a średni czas pokonania całej trasy to $63 \mathrm{~min}$. Do obsługi 29 stacji potrzeba 16 sześciowagonowych pociagów o nazwie C Stock.

Linia Circle wyróżnia się tym, że obsługuje większość głównych stacji kolejowych. Dzieli prawie cała 27-kilometrową trasę z trzema innymi liniami: District, Hammersmith \& City i Metropolitan. Do obsługi 35 stacji w godzinach szczytu potrzebuje 16 sześciowagonowych pociagów o nazwie C Stock.

Jubilee jest najnowszą z istniejących linii, ale częściowo porusza się po torach wybudowanych ponad 100 lat temu. Ostatnia ze stacji została oddana do użytku w grudniu 1999 r. Jej długość to 36,2 km i jest jedyna linią, która ma połączenie ze wszystkimi pozostałymi. Trasa przebiega z północy, kierując się na południe, przecina rzekę, obsługuje kilka stacji na południu miasta (centrum finansowe w okolicach Canary Wharf) i kończy we wschodniej części. Połączenie w godzinach szczytu obsługuje 47 sześciowagonowych pociaggów o nazwie 1996 Stock.

Długość linii Northern to $58 \mathrm{~km}$. Połączenie przecina miasto z północy na południe. W centrum rozdziela się na dwie części. Na północy rozgałęzienia łączą się na stacji Camden Town i ponownie rozdzielaja. Jedna biegnie w kierunku High Barnet, a druga do Edgware. Do obsługi w godzinach szczytu potrzeba 84 sześciowagonowych pociagów. Lnia Northern obsługuje najbardziej na południe wysunięty punkt znajdujący się w zasięgu sieci metra - Morden. Tunel pomiędzy stacja East Finchley i Morden jest jednym z najdłuższych na świecie i najdłuższym w mieście - mierzy $27,8 \mathrm{~km}$. To połączenie bije także inne rekordy. Wiadukt Dollis Brook jest najwyżej położonym punktem sieci trakcyjnej w Londynie, natomiast w Holly Bush 67,4 km pod ziemią znajduje się najniżej położony punkt ${ }^{17}$.

Linia District o długości $64 \mathrm{~km}$ obsługuje 60 stacji, jednak tylko 42 z nich znajduje się na głównej prostej. Jest najbardziej skomplikowaną do obsługi linią w mieście. Na wschodzie dojeżdża tylko do Upminster, ale na zachodzie rozdziela się w trzech kierunkach - do Ealing, Richmond i Wimbledon. W centrum korzysta z torów razem z linia Circle, a połaczenie z Wimbledon do Edgeware Road i Olympia jest obsługiwane całkiem osobno. Rozgałęzienia spotykają się w Earl's Court, gdzie znajduje się centrum operacyjne. Główna linia do obsługi wymaga 98 pociagów D Stock. Dodatkowa nitka obsługiwana jest przez 8 maszyn C Stock.

${ }^{17}$ www.tfl.gov.uk/corporate/modesoftransport/londonunderground/keyfacts/13174. aspx [z dn. 11.10.2012]. 
Trasa linii Metropolitan o długości 66,7 km przebiega od centrum miasta na północny zachód. Jest to pierwsza na świecie oddana do użytku linia metra. Tylko 9,7 km całej trasy położone jest pod ziemia. Obsługuje 24 stacje, a w godzinach szczytu potrzebuje 49 ośmiowagonowych pociągów A Stock. Na linii Metropolitan znajduje się najbardziej zatłoczona w mieście stacja kolejowa - King's Cross. Główna zajezdnia mieści się w Neasden. Połączenie dociera do oddalonego o $43 \mathrm{~km}$ od centrum, najbardziej na zachód wysuniętego punktu, obsługiwanego przez system metra - Amersham.

Siedemdziesięcioczterokilometrowa trasa linii Piccadilly prowadzi ze wschodu przez centrum i na zachodzie rozgałęzia się w kierunku lotniska Heathrow i Uxbridge. Linię obsługuje 79 sześciowagonowych pociągów o nazwie 1973 Stock. Maja one specjalne miejsce na bagaże, przeznaczone dla podróżujacych z lub na lotnisko. Maszyny były poddane całkowitej renowacji w 2000 r. przez firmę Bombardier Pro Rail. Pociaggi linii Piccadilly jako pierwsze na linii głębokotunelowej zostały przystosowane w 1987 r. do jednoosobowej obsługi.

Długość 74 km czyni z linii Central najdłuższą w mieście. Całą 54,9-kilometrową podróż linią Central pomiędzy West Ruislip a Epping można odbyć w niecałe półtorej godziny. Siedemdziesiąt dwa ośmiowagonowe pociaggi o nazwie 1992 Stock potrzebne sa do obsługi linii podczas godzin szczytu. To najdłuższe połączenie ma za zadanie obsłużyć dość rozległy obszar miasta: północny zachód, północny wschód i centrum.

Każda z opisanych linii ma charakterystyczny dla siebie rodzaj taboru. Podstawowy podział obejmuje maszyny obsługujące głębokie tunele (deep level) oraz takie, które jeżdża w płytkich tunelach budowanych metodą odkrywkową lub biegnące na powierzchni (sub-surface). Główną różnicę stanowi rozmiar wagonów. Musi być on dopasowywany do tunelu. Pierwsze miały średnicę 3,1 m, później wzrosło to do 3,6 m, a ostatecznie linia Victoria ma średnicę tunelu 3,8 m. Ważnymi czynnikami decydującymi o przyporządkowaniu konkretnego taboru do linii są również: krzywizna terenu, długość peronów oraz - w dzisiejszych czasach - system sygnalizacji. Przykładowo, na liniach Victoria i Central platformy mają długość 121 m oraz specyficzny automatyczny system sterowania sygnalizacja. Większość platform na innych liniach ma ok. 106 m długości. Linie naziemne budowane metoda odkrywkowa są szerokie, dlatego moga być obsługiwane przez prawie każdy rodzaj taboru. Maszyny obsługujące głębokie tunele identyfikujemy za pomocą roku, w którym była zaplanowana ich dostawa, natomiast pociągi sub-surface za pomoca litery i dwóch cyfr oznaczających rok wejścia do użytku. Żywotność taboru jest oceniona i ustalona na 40 lat, jednak remonty są w stanie przedłużyć użyteczność o 10-15 lat i w ten sposób 
pozwalają zaoszczędzić ogromne sumy pieniędzy. Odnowa kosztuje tylko 1/16 tego, co nowy pociagg. Poniżej przedstawiona zostanie krótka charakterystyka wszystkich maszyn obsługujaccych obecnie sieć metra.

Tabor 1967 (1967 Stock) jest najstarszym obecnie używanym. Kursuje na linii Victoria i liczy sobie 43 ośmiowagonowe pociagi. Został zaprojektowany dla pierwszej w pełni automatycznej kolei. Wybudowany w latach 1967-1969 przez firmę Metro Cammell i w całości oddany do użytku w 1971 r. Został wyremontowany w latach 1991-1994 przez firmę Tickford Rail Limited. W jednym pociągu są 304 miejsca siedzące i 1144 stojace ${ }^{18}$.

Tabor 1972 (1972 Stock) wybudowany przez firmę Metro-Cammell i oddany do użytku w latach 1972-1975, kursował na linii Northern, obecnie obsługuje linię Bakerloo. Wygląda tak samo jak tabor 1967, ale nie jest automatycznie sterowany. W skład floty wchodzi 36 siedmiowagonowych maszyn, obsługiwanych przez jedna osobę. Poddany procesowi renowacji w latach 1991-1995 przez Tickford Rail Limited. W pociągu znajduja się 264 miejsca siedzące i 1014 miejsc stojących ${ }^{19}$.

Tabor 1973 (1973 Stock) został wybudowany przez firmę MetroCammell i oddany do użytku w latach 1975-1978. Osiemdziesiąt sześć sześciowagonowych pociągów obsługuje linię Piccadilly. Były one odnawiane w latach 1995-2000 przez firmę Bombardier Pro Rail. Maszyny obsługiwane przez jedną osobę posiadaja $228+44$ miejsca siedzące i 966 stojacych. Konserwacja zajmuje się firma Tube Lines. Planowane jest zastapienie taboru nowym w $2014 \mathrm{r}^{20}$

Tabor 1992 (1992 Stock) stworzony przez ABB Transportation obsługuje dwie linie: Central i Waterloo \& City. Został oddany do użytku w latach 1991-1994. Flota linii Waterloo \& City była odnawiana w 2006 r. przez Bombardier Transportation UK i jest teraz obsługiwana przez 5 czterowagonowych pociągów. Linia Central obsługiwana jest przez 85 ośmiowagonowych maszyn, w których są 272 miejsca siedzące oraz 620 stojących ${ }^{21}$.

Tabor 1995 (1995 Stock) obsługuje linię Northern. Maszyny zostały wytworzone przez firmę Alstom Transportation i oddane do użytku w latach 1997-2000. Tabor składa się ze 106 sześciowagonowych maszyn, konserwowanych przez firmę Alstom na mocy umowy podpisanej

${ }^{18}$ www.tfl.gov.uk/corporate/modesoftransport/londonunderground/rollingstock/1620.aspx [z dn. 11.10.2012].

${ }^{19}$ www.tfl.gov.uk/corporate/modesoftransport/londonunderground/rollingstock/1622.aspx [z dn. 11.10.2012].

${ }^{20}$ www.tfl.gov.uk/corporate/modesoftransport/londonunderground/rollingstock/1624.aspx [z dn. 2.12.2011].

${ }^{21}$ www.trainweb.org/tubeprune/72\%20tube\%20stock.htm [z dn. 11.10.2012]. 
z Tube Lines. Pociagg obsługiwany jest przez jedną osobę, posiada 248 miejsc siedzących i 914 stojących ${ }^{22}$.

Tabor 1996 (1996 Stock) zbudowany przez firmę Alstom Transportation, był oddany do użytku w dwóch turach: w latach 1997-2000 i 2005-2006. Składa się z 63 siedmiowagonowych pociagów, jeżdżących na linii Jubilee. Maszyny obsługiwane sa przez jedną osobę. Konserwacją zajmuje się firma Alstom. W pociągu znajdują się 234 miejsca siedzące oraz 730 stojacych $^{23}$.

Tabor 2009 (2009 Stock) był zaprojektowany i zbudowany przez firmę Bombardier Transportation. Przeznaczony do obsługi linii Victoria i zastapienia najstarszego taboru 1967. Pierwsza maszyna rozpoczęła pracę 21 lipca 2009 r. Następne wchodziły do użytku co dwa tygodnie, od początku 2010 r. Nowe pociągi maja 252 miejsca siedzące i 1196 miejsc stojących ${ }^{24}$.

Tabor A60 i A62 (A60 i A62 Stock) zostały zaprojektowane i wybudowane przez firmę Cravens do obsługi linii Metropolitan. Pierwsza tura o nazwie A60 była wyprodukowana na potrzeby przedłużania linii Metropolitan o sekcje do Amersham. Natomiast tabor A62 został oddany od użytku na drugiej gałęzi linii Metropolitan do Uxbridge. W związku z tym, że linia Metropolitan jest bardzo rozległa i podróż trwa bardzo długo, wagony są wyposażone w duże wygodne siedzenia niespotykane w innych typach pociągów. Weszły do użytku w latach 1961-1963. Obecnie oba typy obsługuja cała linię. Renowację w latach 1994-1997 wykonała firma ADtranz LTD. Tabor składa się z 56 ośmiowagonowych pociągów z 448 miejscami siedzącymi i 976 stojacymi ${ }^{25}$.

Tabor C67 i C77 (C67 \& C77 Stock) był wybudowany przez firmę Metro Cammell i oddawany do użytku w dwóch turach w latach 70. Obsługuje linię Circle, Hammersmith i City oraz częściowo District. Od taboru "A" różni się tym, że został zaprojektowany dla typowo miejskiego zagęszczenia ruchu z krótkimi przystankami i dużą liczbą ludzi wychodzących i wchodzących. Maszyny były odnawiane w latach 1991-1994 przez firmę RFS Industries. Tabor C67 składa się z 35 sześciowagonowych pociągów, a tabor C77 z 11 sześciowagonowych maszyn ${ }^{26}$.

${ }^{22}$ www.tfl.gov.uk/corporate/modesoftransport/londonunderground/rollingstock/ 1628.aspx [z dn. 02.12.2011].

${ }^{23}$ www.tfl.gov.uk/corporate/modesoftransport/londonunderground/rollingstock/ 1630.aspx [z dn. 02.12.2011].

${ }^{24}$ www.bombardier.com/en/transportation/products-services/rail-vehicles/metros/ Iondon--united-kingdom?docID $=0901260 \mathrm{~d} 8000 \mathrm{~d} 19 \mathrm{e} \#[\mathrm{z} \mathrm{dn} .11 .10 .2012]$.

${ }^{25}$ www.tfl.gov.uk/assets/downloads/foi/Rolling_stock_Data_Sheet_2nd_Edition.pdf [z dn. 11.10.2012].

${ }^{26}$ www.tfl.gov.uk/corporate/modesoftransport/londonunderground/rollingstock/ 1616.aspx [z dn. 11.12.2011]. 
Tabor D78 (D78 Stock) wykonała firma Metro Cammell do obsługi linii District. Był oddany do użytku w latach 1979-1983 i składa się z 75 sześciowagonowych maszyn. Wyremontowany przez firmę Bombardier Transportation w latach 2004-2008. Pociaggi posiadaja 280 miejsc siedzących i 1092 stojące ${ }^{27}$.

\subsection{Plany rozwoju i modernizacji miejskiej kolei podziemnej}

W Londynie trwa obecnie największy w historii remont sieci metra. Planuje się, że po zakończeniu wszystkich prac przepustowość sieci wzrośnie o 30\%. Gdyby nie rozpoczęto modernizacji, wkrótce przepustowość spadłaby o 30\%, jako że coraz więcej ludzi korzystałoby z przestarzałego systemu. Kilka projektów już się zakończyło, wiele trwa lub dopiero ma się rozpocząć. Firma TfL zadbała o to, aby liczne przebudowy w jak najmniejszym stopniu przeszkadzały użytkownikom systemu. Na oficjalnej stronie TfL udostępnione sa aktualne informacje na temat trwających i mających się rozpocząć projektów. Można dowiedzieć się, kiedy rozpoczną się prace i na kiedy planowane jest zakończenie. Podróżny może przeczytać, w jaki sposób remonty moga wpłynąć na jego podróż oraz zapoznać się z alternatywnymi trasami. Informacje są dostępne nie tylko w Internecie, ale także na stacjach. Przy trwających lub mających się rozpocząc remontach bardzo ważną kwestia jest uczynienie jak największej liczby stacji łatwo dostępnymi dla osób z ograniczona mobilnością ${ }^{28}$. Obecnie w sieci metra 58 stacji jest przystosowanych dla potrzeb tych podróżujących.

Przełomowym momentem było przedłużenie linii Piccadilly o nowa sekcję obsługująca nowo powstały Terminal 5 na lotnisku Heathrow. Pierwszy pociąg pojechał na stację terminalu w marcu 2008 r. Było to pierwsze rozszerzenie od 1999 r. i można powiedzieć, że rozpoczęło realizację ogromnego projektu inwestycyjnego.

Gruntowny remont linii Jubilee (czyli ulepszenie sieci trakcyjnej, taboru oraz centrum kontroli, a także instalacja najnowszej sygnalizacji) zakończył się w 2010 r. Do końca 2012 r. wszystkie stacje na trasie zostały zmodernizowane. Tabor 1996 obsługujący linię w grudniu 2006 r. został wydłużony z sześciu do siedmiu wagonów, co podniosło zdolność przewozową o 17\%. Te wszystkie renowacje mają się złożyć

${ }^{27}$ www.tfl.gov.uk/assets/downloads/foi/Rolling_stock_Data_Sheet_2nd_Edition.pdf [z dn. 11.10.2012].

${ }^{28}$ Niepełnosprawni, ludzie z dziećmi w wózkach, ludzie starsi, a także podróżujący z bagażami. 
na ostateczny wzrost przepustowości o 33\% i skrócenie czasu podróży o 22\%. W związku z Olimpiadą i Paraolimpiada w 2012 r., przebudowano na potrzeby osób z ograniczona mobilnością stację Green Park, którą linia Jubilee dzieli również z liniami Victoria i Piccadilly. Kluczowe zmiany to:

- instalacja 3 nowych wind zapewniających dostęp z ulicy do wszystkich trzech platform,

- powiększenie wejścia na stacje,

- budowa nowej rampy.

Jedna z nowych wind będzie przewozić pasażerów do hali biletowej, a kolejne dwie na platformy.

Kolejna gruntownie odnawiana stacja na trasie linii Jubilee będzie Bond Street. Znajduje się ona w samym środku największego obszaru handlowego w mieście. Około 155 tys. pasażerów codziennie korzysta ze stacji. Po uruchomieniu w 2017 r. nowego połączenia Crossrail liczba ta ma wzrosnąc do 255 tys. ${ }^{29}$ W ramach przystosowania stacji do nowego połączenia oraz usprawnienia korzystania z linii Jubilee i Central planuje się stworzenie nowego większego wejścia. Przekształci ono stację w całkowicie dostępna dla osób z ograniczona mobilnością, a także zapewni bezpośredni dostęp do nowego połączenie kolejowego Crossrail.

W dwóch fazach realizowana jest modernizacja najstarszej stacji metra i dworca kolejowego w Londynie King's Cross St. Pancras. Pierwsza faza dotycząca budowy zachodniej hali biletowej została ukończona. Nowy obiekt zapewnia bezpośredni dostęp do platform linii Circle i Metropolitan, a także do międzynarodowego dworca St. Pancras. Ulepszenia spowoduja wzrost sprawności systemu oraz łatwiejsze połączenie pomiędzy dworcem a liniami metra. W ramach fazy pierwszej zostały odnowione i powiększone również hole wejściowe wspomnianych linii Circle i Metropolitan. Prace nad druga faza już trwaja. 29 grudnia 2009 r. została oddana do użytku północna hala biletowa o powierzchni $2000 \mathrm{~m}^{2}$. Zamontowano w niej 10 nowych ruchomych schodów, zbudowano 6 wejść dla osób z utrudniona mobilnościa oraz skonstruowano około $300 \mathrm{~m}$ tuneli, mających łączyć ze sobą linie Northern, Piccadilly Victoria oraz dworzec King's Cross. W budynku będą obsługiwane połączenia krajowe i zagraniczne na stacji St. Pancras oraz krajowe przejazdy na stacji King's Cross. Faza druga zakończyła się w połowie $2010 \mathrm{r}$.

${ }^{29}$ www.tfl.gov.uk/assets/downloads/corporate/Bond-street-newsletter-Winter-2009.pdf [z dn. 08.02.2010]. 
Firma Bombardier Transportation dostarcza nowy tabor do obsługi linii sub-surface Metropolitan, District, Circle oraz Hammersmith \& City. Na początku 2010 r. pierwsza nowa maszyna pojawiła się na linii Metropolitan. Tabor na wszystkich liniach będzie takiego samego typu, jedyną różnicę będzie stanowiła długość (inna dla każdej linii). Wagony będą połączone ze sobą bezpośrednio tak, że podróżujący będą mogli przechodzić pomiędzy nimi w trakcie jazdy. Każdy pociąg będzie posiadał klimatyzację, większe okna i drzwi oraz energooszczędny system hamowania. W londyńskim metrze takie rozwiązania pojawiaja się po raz pierwszy. Ta sama firma zajmuje się wymiana systemu sygnalizacji na tych liniach oraz organizacja nowych centrów operacyjno-kontrolnych ${ }^{30}$. Linia Circle, która otrzyma 53 nowe maszyny, została 13 grudnia 2009 r. wydłużona o nową sekcję do Hammersmith \& City. Dzięki temu pociągi będą jeździć z większą częstotliwościa, bardziej punktualnie oraz będą mniej zatłoczone. Po ukończeniu wszystkich prac na linii w 2016 r., przepustowość ma wzrosnać o 65\%. Na linii Hammersmith \& City w 2013 r. będą kursowały już 53 nowe maszyny. Linia District będzie obsługiwała najwięcej, bo aż 80 pociągów wybudowanych przez firmę Bombardier Transportation. W 2018 r., po wprowadzeniu wszystkich zmian, przepustowość linii ma wzrosnąć o $24 \%$. Zakończył się również remont stacji Southfileds, która stanowi strategiczny punkt w obsłudze wydarzeń takich jak Olimpiada w 2012 r. czy Mistrzostwa Tenisowe Wimbledon. Znajduja się tam korty tenisowe i boiska do krykieta. Prace miały na celu uczynienie stacji bardziej dostępnej dla wszystkich podróżujących.

Linia Metropolitan po otrzymaniu 58 nowych pociagów oraz instalacji nowego systemu sygnalizacji i udoskonaleniu centrum kontroli zwiększy przepustowość o $27 \%$. Ponadto trwaja prace nad projektem rozszerzenia linii Metropolitan do Watford Junction. Nowy odcinek będzie poprowadzony przez nieczynną stację należąca do Kolei Narodowej oraz - po przebudowie - po używanych kiedyś torach. Cały proces wraz z uzyskaniem niezbędnych pozwoleń, zdobyciem środków finansowych oraz samą budową będzie trwał 5-7 lat. Głównym celem rozszerzenia jest redukcja kongestii na drogach oraz udoskonalenie połączenia z centrum miasta. Po realizacji projektu pociagi linii Metropolitan mogłyby kursować z częstotliwościa co 10 min, zapewniając mieszkańcom szybkie połączenie. Rozbudowa nie tylko ma ułatwić podróż do centrum, lecz także umożliwić dostęp do atrakcji

${ }^{30}$ www.bombardier.com/en/transportation/products-services/rail-vehicles/metros/ london-united-kingdom?docID $=0901260$ d8000d19e [z dn. 11.10.2012]. 
okolicy, m.in. Centrum Harlequin. Będzie wymagała wykonania następujących prac ${ }^{31}$ :

- budowy dwóch nowych stacji Ascot Road i Watford West,

- konstrukcji nowego wiaduktu, łączącego istniejąca linię ze stara siecia kolejowa,

- dobudowania drugiej trakcji do istniejących torów,

- remontu platform na stacjach Watford High Street i Watford Junction,

- zamknięcia stacji Watford i odcinka linii Metropolitan.

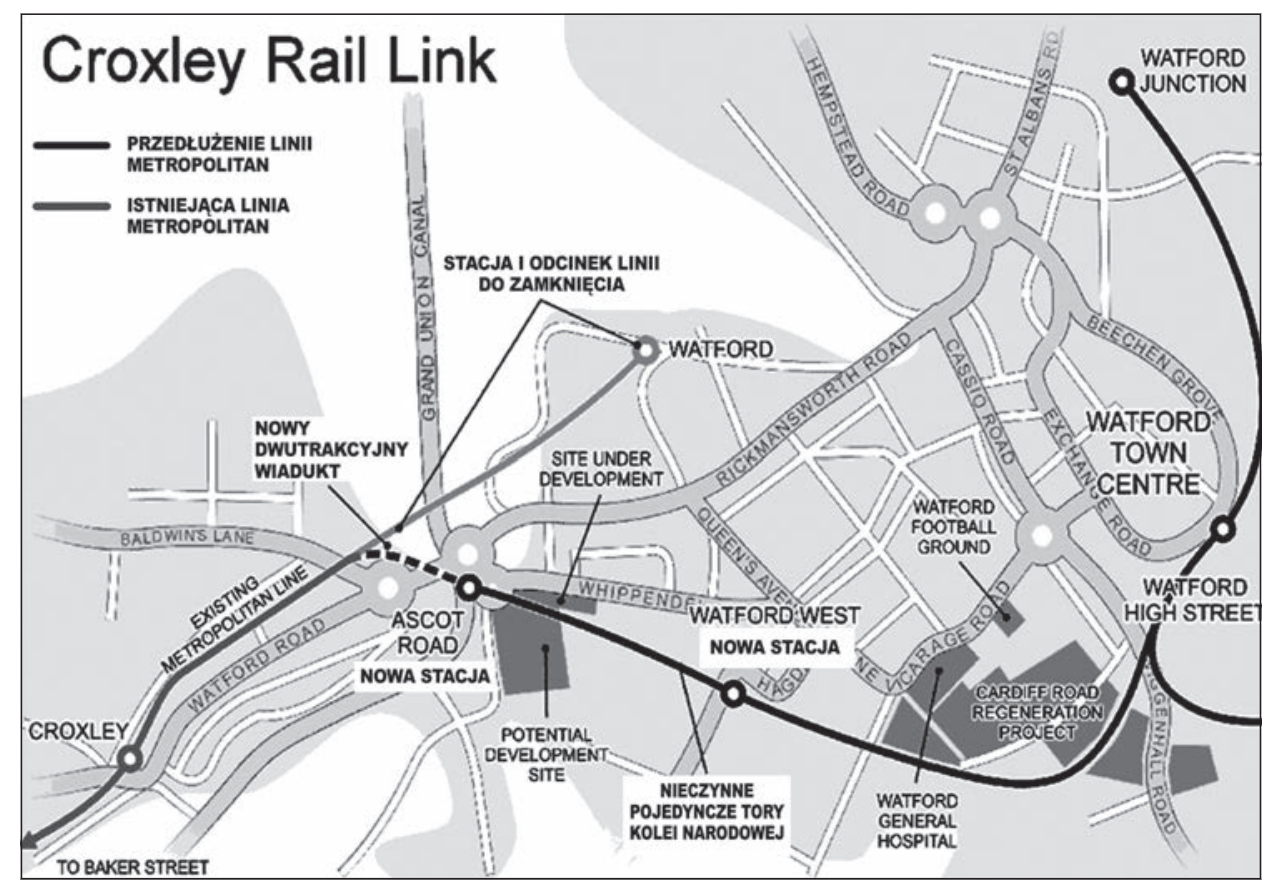

Rysunek 24. Projekt przedłużenia linii Metropolitan do Watford Junction

Źródło: opracowanie własne na podstawie www.tfl.gov.uk/assets/ downloads/corporate/croxley-map.GIF [z dn. 01.12.2011]

Nowy tabor wyprodukowany przez firmę Bombardier Transportation został wprowadzony także na linii Victoria. Pierwszy nowy pociąg rozpoczął pracę w lipcu 2009 r. Reszta z 47 ośmiowagonowych maszyn była stopniowo wdrażana przez kolejne dwa lata. Cały remont wykonywany na linii, obejmujący instalację nowej sygnalizacji, nowego centrum operacyjnego, wymianę trakcji, został ukończony w 2012 r. i ma przynieść 21-procentowy wzrost przepustowości, a także skrócić czas podroży o $16 \%$.

${ }^{31}$ www.tfl.gov.uk/corporate/projectsandschemes/networkandservices/6153.aspx [z dn. 11.12.2011]. 
Linia Northern jest najbardziej zatłoczona w całym systemie. Dziennie obsługuje 750 tys. osób za pomoca 91 pociagów na 6 gałęziach linii. Nowa sygnalizacja i centrum kontroli pozwoli na kursowanie większej liczby pociągów w tym samym czasie, a także umożliwi zwiększenie ich prędkości, co skróci czas podroży o 18\%. Do końca 2018 r. planowane jest rozdzielenie pociągów kursujących na trasie Morden do Bank i Kennington do Charing Cross. Pozwoli to na zwiększenie liczby kursów na godzinę z 20 do nawet 32 na wszystkich nitkach linii, co poprawi efektywność o $20 \%{ }^{32}$.

Pod koniec 2008 r. zostało oddanych do użytku wiele obiektów w okolicy White City i Shepherd's Bush. Jest to wynik ogromnego projektu finansowanego przez Westfield London i TfL. Prace miały na celu usprawnienie transportu na tym obszarze, tak aby powstały nowe możliwości i miejsca pracy dla mieszkańców. W ramach projektu zrealizowano ${ }^{33}$ :

- budowę stacji Shepherd's Bush Overground (stacja kolei metropolitarnej),

- budowę stacji Wood Lane na linii Hammersmith \& City,

- renowację stacji Shepherd's Bush na linii Central,

- renowację stacji White City na linii Central.

$\mathrm{Na}$ linii Hammersmith \& City powstała pierwsza od 70 lat stacja Wood Lane. Znajduje się w odległości 200 m od stacji White City i umożliwia podróżującym przesiadkę na linię Central. Dzięki temu uzyskano wygodne połączenie do centrum miasta, a także na międzynarodową stację kolejowa St. Pancras International. Po intensywnym remoncie została oddana do użytku stacja Shepherd's Bush. Została przebudowana tak, aby obsłużyć zwiększona po rewitalizacji obszaru liczbę pasażerów. Na tej stacji będa wysiadali wszyscy podróżni chcący przesiąść się na połączenia London Overground. Stacja White City na linii Central została odnowiona, aby podnieść komfort podroży. Zainstalowano tam nowe kamery, zorganizowano nowy system informacji i usprawniono oświetlenie.

\section{Podsumowanie}

W wyniku analiz przeprowadzonych w niniejszym rozdziale sformułowano następujące wnioski:

- Sukcesu pierwszych linii metra w Londynie można upatrywać w tym, że były to prywatne inwestycje, które przynosiły właścicielom wymierne korzyści finansowe.

\footnotetext{
${ }^{32}$ www.tfl.gov.uk/corporate/projectsandschemes/10133.aspx [z dn. 11.10.2012].

${ }^{33}$ www.tfl.gov.uk/corporate/projectsandschemes/9337.aspx [z dn. 12.12.2011].
} 
- Własność prywatna i duża konkurencja była jednocześnie barierą rozwojowa, powodem wysokich cen przejazdów oraz braku integracji budowy i funkcjonowania poszczególnych linii.

- Powstanie technologii umożliwiającej drążenie głębokich tuneli oraz zastosowanie energii elektrycznej do zasilania pociągów było przełomem, który spowodował bardzo szybki rozwój ogromnej sieci metra.

- Inicjatywy mające na celu zgromadzenie wszystkich linii pod jednym zarządem pojawiły się już na początku XX wieku i przyczyniły się do integracji inwestycji oraz sukcesu marketingowego (cały świat dowiedział się o systemie londyńskiego metra i zaczałł się na nim wzorować).

- Z uwagi na wiele czynników przewozy autobusowe maja większy niż metro udział w ogóle przewozów, jednak roli metra nie można przecenić w przejazdach na terenie strefy centralnej oraz z obrzeży aglomeracji do centrum.

- Spółka Transport for London utworzona w 2000 r. podlega władzom miasta i realizuje strategię transportową. Burmistrz jest odpowiedzialny za całość transportu na terenie miasta, co pozwala na zintegrowane działania i efektywne modelowanie całego systemu. 


\section{Rodzaje miejskiego transportu szynowego w Londynie}

Magdalena Drzewoszewska*

\subsection{Charakterystyka lekkiej kolei nadziemnej}

Lekka kolej została uruchomiona w 1987 r. do obsługi dzielnicy London Docklands. Trzy lata wcześniej przetarg na budowę wygrała firma GEC-Mowlem Railway, która zobowiązała się zaprojektować, wybudować i wyposażyć kolej. W skład jej infrastruktury w dniu otwarcia wchodziło 11 pociągów i 15 stacji. Obsługiwała połączenia pomiędzy Tower Gateway, Stratford i Island Gardens. Po wielu rozbudowach i modernizacjach osiagnęła stan dzisiejszy: 34 km torów, 40 stacji i 100 pociągów. Swoim zasięgiem obejmuje lokalizacje takie jak: Bank, Beckton, Lewisham, London City Airport i Woolwich Arsenal. System obsługuje $67 \mathrm{mln}$ pasażerów rocznie, ale do 2012 r. ta liczba miała wzrosnąć do $100 \mathrm{mln}^{1}$. Zarządzana jest przez Docklands Light Railway Ltd (DLR), które jest częścią Transport for London. Na podstawie umowy franczyzowej utrzymaniem systemu w ruchu oraz jego renowacja zajmuje się firma Serco Docklands. DLR jest odpowiedzialna za planowanie i wprowadzanie projektów rozszerzających zasięg połączeń. Zajmuje się także rozwijaniem i ulepszaniem infrastruktury. Firma jest wspierana przez trzech koncesjonariuszy, którzy zaprojektowali, zbudowali i sfinansowali ostanie rozbudowy.

Jednym z kluczowych założeń rozwoju lekkiej kolei jest regeneracja terenów objętych jej połączeniami. System odegrał kluczową rolę w rozwoju i rewitalizacji obszaru wschodniego i południowo-wschodniego Londynu, umownie nazwanego London Docklands. W przeszłości na tych terenach mieścił się jeden z największych portów na świecie - Port of London, odizolowany od reszty miasta, posiadający swoja specyficzną kulturę i slang, ze słabo rozwiniętą infrastruktura drogową i komunikacyjna. Kiedy w latach 70. XX wieku transport wodny wprowadził system przewozów, cargo port upadł ze względu na niemożność obsługi

* Mgr Magdalena Drzewoszewska - Katedra Logistyki, Wydział Zarządzania Uniwersytetu Łódzkiego, ul. Matejki 22/26, 90-237 Łódź.

${ }^{1}$ www.tfl.gov.uk/corporate/modesoftransport/dlr/1538.aspx [z dn. 11.10.2012]. 
ogromnych kontenerów. Pozostawił po sobie 21 km² opuszczonego terenu, zasiedlonego przez rzesze bezrobotnych. Ogromny projekt rewitalizacyjny w latach 1980-1990 sprawił, że London Docklands stało się drugim finansowym centrum miasta, a dzielnica Canary Wharf - ogromnym skupiskiem drapaczy chmur. Kluczową rolę odegrał rozwój komunikacji, do którego przyczyniło się stworzenie lekkiej kolei (DLR) łączącej teren dawnego portu z centrum miasta. Dalszy rozwój połączeń pomógł zrewitalizować tereny wokół Docklands, min. Greenwich².

DLR jest zintegrowana z innymi systemami transportowymi. Ma bezpośrednie połączenie ze 100 liniami autobusowymi, 8 liniami metra, 4 liniami London Overground (miejskie połączenia kolejowe zarządzane przez British Rail), a także z siecią autokarów, taksówek i transportem rzecznym.

Kolejka DLR jest liderem w transporcie przyjaznym dla środowiska. Znajdują tutaj zastosowanie pionierskie metody, pozwalające chronić środowisko poprzez oszczędność energii, wody i poddanie śmieci recyklingowi. Oto niektóre rozwiązania wprowadzone w systemie i na stacjach:

- pociąg hamując traci energię, a dzięki systemowi energooszczędnego hamowania jest ona akumulowana w torach i zasila następny przejeżdżający pociąg,

- gazety i śmieci pozostawione w wagonach sa poddawane recyklingowi,

- woda przeznaczona do mycia taboru jest używana kilkakrotnie,

- oświetlenie stacji wyłącza się automatycznie, kiedy nie jest potrzebne, dzięki zainstalowanym sensorom światła dziennego,

- używanie materiałów z recyklingu do budowy zadaszeń na stacjach (np. na stacji West India Quay zadaszenie jest wykonane w $90 \%$ z takich materiałów),

- ruchome schody na nowych stacjach Tower Gateway, South Quay i obecnie budowanej Stratford International będa jechały $z$ pełna mocą tylko wtedy, gdy będą aktualnie używane przez pasażerów,

- garaże rowerowe posiadaja oświetlenie zasilane panelami słonecznymi,

- w toku sa prace nad wdrożeniem paneli słonecznych do zasilania sygnalizacji.

DLR podczas budowy stacji Stratford International stara się jak najbardziej zredukować szkodliwość dla otoczenia oraz korzystać z przyjaznych dla środowiska praktyk. Prawie 90\% gruzu, który wykopano w celu budowy nowej infrastruktury zostało poddane procesowi recyklingu. Stare tory dawnej linii North London zostały odnowione i użyte w nowym systemie. Wszystkie maszyny napędzane były paliwami o niskiej zawartości siarki, aby zmniejszyć negatywny wpływ na jakość powietrza.

\footnotetext{
${ }^{2}$ www.lddc-history.org.uk/beforelddc/index.html [z dn. 11.10.2012].
} 
Lekka kolej DLR odgrywała kluczową rolę w transporcie ludzi podczas Igrzysk Olimpijskich w 2012 r. W zasięgu sieci znajdują się 4 miejsca rozgrywek: Olimpic Park, ExCel, Greenwich Park i Woolwich Artillery Barracks. System musiał obsłużyć około 500 tys. pasażerów dziennie. Zwykła przepustowość to tylko 250 tys. tygodniowo. Wszystkie projekty związane z przygotowaniami do rozgrywek olimpijskich pozostawiły po sobie infrastrukturę, która znacząco wspomoże przyszły rozwój i funkcjonowanie stolicy. Następujące projekty były ukończone do czasu otwarcia Olimpiady:

1) budowa linii DLR od Canning Town do Stratford international,

2) powiększenie pociągów jeżdżących na trasach pomiędzy Poplar i Beckton z dwóch do trzech wagonów.

\section{Ad 1)}

Linia pomiędzy Canning Town a Stratford była budowana w ramach projektu rozwoju obszaru pomiędzy tymi lokalizacjami. Nowe połączenie ma być impulsem do powstania miejsc pracy, mieszkań, sklepów, centrów rozrywki i kultury. Poprawi dostęp mieszkańców do komunikacji i da im perspektywę inną od poruszania się autem. Stworzy połaczenie międzynarodowej stacji kolejowej Stratford z siecią komunikacji miejskiej Londynu. Nowo powstała linia była kluczowa dla obsługi Parku Olimpijskiego w Stratford podczas Igrzysk w Londynie w 2012 r.

Linia ma długość $6 \mathrm{~km}$ i zakłada powstanie czterech nowych stacji:

- Stratford International,

- Stratford High Street,

- Abbey Road,

- Star Lane.

Projekt wykorzystuje dawne stacje North London Line (północnej linii kolejowej), które będa przystosowane do wymogów systemu DLR. Podróż od stacji Stratford International do Canning Town ma trwać $10 \mathrm{~min}^{3}$.

\section{Ad 2)}

W związku ze wzrostem liczby podróżujących z $70 \mathrm{mln}$ rocznie do 100 mln w 2012 r. DLR dołoży do kursujących na najpopularniejszych połączeniach składów dodatkowy wagon. Powiększone pociągi jeżdżą na wybranych trasach od 2010 r. i powiększą liczbę miejsc dla pasażerów o 50\%. Po powiększeniu infrastruktury, DLR będzie zarządzało 149 wagonami. Na realizację projektu składają się następujące prace ${ }^{4}$ :

- wydłużenie platform na 17 stacjach,

- wzmocnienie wiaduktów i mostów,

${ }^{3}$ www.tfl.gov.uk/assets/downloads/corporate/dlr-factsheet-july-2009.pdf [z dn. 9.01.2010].

${ }^{4}$ Tamże. 
- budowa nowej stacji South Quay Station,

- budowa nowych węzłów kolejowych w pobliżu: West India Quay, Canning Town i Tower Gateway, aby zwiększyć częstotliwość kursowania,

- budowa większej ilości wind i ruchomych schodów na stacjach,

- zakup 55 nowych wagonów.

Nowa stacja South Quay została otwarta 26 października 2009 r. Zastapi stara stacje Quay Station, która z powodów konstrukcyjnych nie mogła być przebudowana na potrzeby trzywagonowych pociagów. Nowa infrastruktura znajduje się w odległości $200 \mathrm{~m}$ od dawnej lokalizacji i jest łatwo dostępna dzięki czterem ruchomym schodom i dodatkowym windom. Remont dla podróżujących oznacza bardziej komfortowe warunki, więcej miejsca na peronach i w pociagach.

\subsection{Specyfika południowolondyńskiej sieci tramwajowej}

Tramlink to 28-kilometrowy system lekkiej kolei, obsługiwany przez 24 tramwaje. Istnieja trzy linie tramwajowe, które zatrzymują się na 39 przystankach ${ }^{5}$. W latach 2001-2008 roczna liczba pasażerów wzrosła z 19 do $26 \mathrm{mln}$.

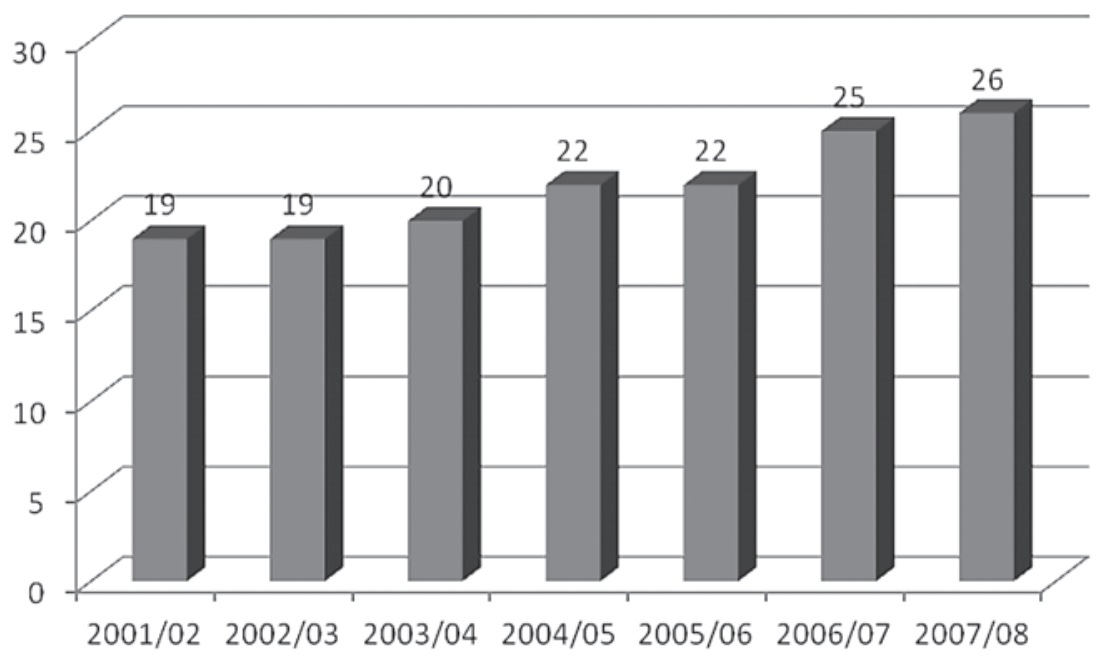

Wykres 6. Liczba obsłużonych pasażerów (w mln) London Tramlink $w$ poszczególnych latach

Źródło: opracowanie własne na podstawie: www.tfl.gov.uk/assets/downloads /corporate/Travel-in-London-report-1.pdf [z dnia 11.10.2012]

${ }^{5}$ www.tfl.gov.uk/corporate/modesoftransport/1566.aspx [z dn. 11.10.2012]. 
Miało to duże znaczenie we wzroście przewozów przez wszystkie rodzaje transportu publicznego. W latach 2007-2008 London Tramlink wykonała $99 \%$ z zaplanowanych według rozkładu jazdy kursów, spośród których 97,2\% było punktualnych ${ }^{6}$. Tym tramwaje zyskały sobie wysoki poziom zaufania pasażerów. Zadaniem sieci jest obsługa terenów południowego Londynu dzielnicy Croydon i Wimbledon. Sa to obszary nieobsługiwane przez żadna z linii metra. System ma połączenie z 7 stacjami National Rail, a także 3 bezpośrednie połączenia z siecią autobusowa. Tramwaje łączą się również z systemem metra na stacji Wimbledon linii District. System tramwajowy jest w pełni dostępny dla osób z utrudniona mobilnością. Opłacając przejazd na wszystkich liniach tramwajowych, można korzystać z elektronicznej karty miejskiej Oyster lub z jednorazowych biletów. W lutym 2008 r. obchodzono niezwykłą rocznicę - jeden z tramwajów odnotował milionowy przejechany kilometr. Na 28-kilometrowej trakcji oznacza to 40 tys. okrążeń7.

Wszystkie przystanki sieci tramwajowej maja niskie platformy, znajdujace się $35 \mathrm{~cm}$ nad poziomem torów. Na każdym z nich umieszczony jest automat biletowy oraz elektroniczny wyświetlacz informacyjny. Pojawiają się tam informacje o miejscu, w jakim się znajdujemy oraz informacja o czasie przyjazdu dwóch następnych tramwajów. Moga być na nim wyświetlane również komunikaty pochodzące od kontrolera ruchu, np. powiadomienie o odwołanych kursach lub opóźnieniach. Wejście do tramwaju znajduje się na poziomie platformy. Drzwi mają szerokość $2 \mathrm{~m}$, co pozwala na swobodny dostęp dla wszystkich. Chodniki wokół stacji sa pod względem wysokości zintegrowane z platformami na przystankach. Tabor tramwajowy został wyprodukowany przez firmę Bombardier Transportation. Długość tramwaju to 30,1 m, a szerokość 2,65 m. W środku jest miejsce dla 208 osób, w tym 70 miejsc siedzących. Maksymalna prędkość to $80 \mathrm{~km} / \mathrm{h}^{8}$.

System zaczał w pełni operować 30 maja 2000 r. po prawie 50 -letniej przerwie. Stara sieć tramwajowa została zamknięta i zdemontowana w 1951 r., aby ustapić miejsca samochodom i autobusom. Dopiero w roku 1986 zaczęto się zastanawiać nad przywróceniem działania systemu. Było to związane z ogromnym zatłoczeniem motoryzacyjnym dzielnicy Croydon oraz brakiem dostępu do komunikacji publicznej nowego obszaru New Addington. Badania przeprowadzone w 1990 r. przez Croydon Council i London Transport wykazały, że ponad $80 \%$

${ }^{6}$ www.tfl.gov.uk/assets/downloads/corporate/Travel-in-London-report-1.pdf [z dn. 11.10.2012].

7 www.tfl.gov.uk/assets/downloads/tramlink-factsheet.pdf [z dn. 12.03.2010].

${ }^{8}$ www.croydon-tramlink.co.uk/info/trams/index.shtml [z dn. 11.10.2012]. 
respondentów wykazuje poparcie dla projektu. Powstało konsorcjum Tramtrack Croydon Ltd, które zdołało stworzyć i zrealizować projekt. Pierwsze tramwaje ruszyły w 1997 r. Budowa sieci tramwajowej jest o wiele mniej kłopotliwa niż tradycyjnej kolei, ponieważ nie potrzeba wygospodarować tak dużych obszarów odizolowanych od reszty transportu. Tramwaje moga podjeżdżać pod większe wzniesienia i pokonywać ostrzejsze zakręty, łatwo je wpasować w istniejąca infrastrukturę. Jedna z ważniejszych zalet tramwajów jest również cichy i gładki sposób jazdy. Mimo że przy produkcji energii elektrycznej wydzielaja się pewne ilości substancji mogących zatruwać powietrze, to same pojazdy nie emituja żadnych zanieczyszczeń i spalin

Zarządzanie tramwajami należy do London Tramlink, które od czerwca 2008 r. jest pod zarządem London Rail. Do jego obowiązków należy utrzymywanie systemu w ruchu, zapewnianie bezpieczeństwa oraz przeprowadzanie remontów, wdrażanie udoskonaleń. Od czasu tego przejęcia zwiększyła się częstotliwość kursowania tramwajów poza godzinami szczytu, a także zadbano, aby w pojazdach i na przystankach było jaśniej i czyściej. W latach 2009-2015 odbędzie się wymiana i renowacja sprzętu, która podniesie znacząco komfort podroży oraz zwiększy przepustowość systemu. W grudniu 2008 r. zorganizowano dodatkowe sprzatanie tramwajów i przystanków. Niezależna inspekcja przeprowadzajacca kontrole w kwietniu 2009 r. odnotowała znaczna poprawę czystości i redukcję śmieci. Zadbano o wiaty na przystankach, które zostały odmalowane, a porysowane i zamalowane szyby zostały wymienione. Zainstalowano również nowe, udoskonalone tablice informacyjne. W związku z potrzeba zgłaszana przez podróżnych w ankietach i wywiadach, od czerwca 2008 r. zwiększono częstotliwość kursowania tramwajów z 2 do 4 na godzinę poza godzinami szczytu na odcinku Beckenham i Elmers End. W poprzedniej sytuacji pasażerowie musieli czekać pół godziny na połączenie, co nie było zgodne z polityką TfL. W październiku 2008 r. pierwszy odnowiony tramwaj rozpoczałł pracę. Kolejne były odnawiane z częstotliwościa jeden na tydzień, a całość prac została ukończona w kwietniu 2009 r. Tramwaje zostały gruntownie wyczyszczone. Zainstalowano nowe siedzenia, pokryte bardziej wytrzymałym i estetycznym materiałem. W środku zamontowane zostały nowe tablice informacyjne.

Przy pomocy TfL został wprowadzony program inspekcji i szybkiej reakcji na pojawiajace się problemy, aby nie były one $w$ stanie niekorzystnie wpłynąc na działanie systemu. Przykładowo, w maju 2008 r.

${ }^{9}$ www.tfl.gov.uk/corporate/modesoftransport/londontrams/1572.aspx [z dn. 11.10.2012]. 
zauważono, że trakcja może odkształcać się pod wpływem wysokiej temperatury i powodować zwolnienie tempa jazdy. W trakcie 10 dni 100 pracowników i dwie maszyny pracowały na 6-kilometrowym odcinku, nakładajac na niego 500 t balastu. To pozwoliło na podniesienie prędkości tramwajów na tej trasie, co dla podróżnych oznaczało szybsze dotarcie do celu. Znaczące remonty odbywaja się w miejscach, gdzie infrastruktura nie nadaje się już do użytku. W lutym 2009 r. wymieniono wykrzywiona sekcję trakcji w Reeves Corner. Remont oznaczał czasowe zawieszenie systemu, dlatego przeprowadzono go podczas zimowej przerwy w szkołach. Całość prac została zakończona w zaplanowanym terminie.

W przygotowaniu jest projekt nazywany "The Next Steps" (ang. kolejne kroki). Przeprowadzane są analizy oraz wywiady z użytkownikami systemu. W związku z postulatami priorytetowa sprawą będzie zmniejszenie zatłoczenia $\mathrm{w}$ tramwajach oraz ułatwienie przesiadek. Pojawiaja się różne propozycje w celu sprostania tym wymaganiom. Rozważa się zwiększenie taboru, wydłużenie istniejących tramwajów, budowę podwójnej trakcji, usprawnienie terminalu na stacji Wimbledon oraz montaż informacyjnych tablic o zmiennej treści.

\subsection{Charakterystyka sieci kolei metropolitarnej}

Należy zaznaczyć, że w tym podrozdziale autorka zajmie się tylko siecią kolejową znajdująca się pod zarządem Transport for London, czyli siecia London Overground. Temat innych operatorów obsługujących stolicę Wielkiej Brytanii jest zbyt obszerny, aby go tu omówić.

W 2004 r. rzad opublikował dokument "Future of Rail" (ang. przyszłość kolei). Stwierdza w nim, że władze Londynu powinny przejąć część odpowiedzialności za kolej obsługująca stolicę. Dokument "The Railway Act", wydany rok później, przekazał burmistrzowi oraz TfL odpowiedzialność za zarządzanie koleją metropolitarną Overground Network, która wcześniej była zarządzana na mocy franczyzy przez Silverlink Trains. W skład przekazanej sieci wchodziły następujące trasy:

- linia North London Line (NLL) z Richmond do North Woolwich,

- linia West London Line (WLL) z Clapham Junction do Willesden Junction,

- linia „Goblin” z Gospel Oak do Barking,

- linia Watford DC pomiędzy Euston i Watford Junction przez Willesden Junction. 
Pierwsze trzy z wymienionych linii zapewniają okrężne połączenie między dzielnicami miasta. Czwarta natomiast pokrywa się częściowo z linią metra Bakerloo. Te cztery linie razem są znane pod nazwą "North London Railway". TfL nazwała sieć London Overground i oznakowała logiem podobnym do używanego na oznaczenie metra.

W 2007 r. odpowiedzialność za zarządzanie siecią kolejową została przekazana należącej do TfL jednostce London Rail, powołanej w 2003 r. w celu opracowania zintegrowanego planu zarządzania koleją oraz podniesienia standardów, skupiając się na inwestycjach w londyńskie koleje. Do obowiązków London Rail należy ${ }^{10}$ :

- nadzorowanie nowych projektów (np. rozbudowy linii East London i renowacji sieci London Overground),

- zarządzanie obsługa sieci Tramlink,

- wspieranie projektu Cross Rail i Thameslink,

- zarządzanie obsługa Docklands Light Railway,

- wpływanie na wkład National Rail w proces integracji publicznego transportu dla Londynu,

- praca z rządem i przemysłem kolejowym nad planami przystosowania londyńskiej kolei do przyszłych potrzeb pasażerów,

- współpraca z przemysłem towarowym w obszarze, wspieranie zrównoważonego przepływu towarów i promocji transportu kolejowego.

W czerwcu 2007 r. do obsługi London Overground wyznaczona zastała London Overground Rail Operations Ltd (LOROL). Zadaniem LOROL jest wypełnianie standardów jakości i bezpieczeństwa, a także zarządzanie ludźmi, częstotliwościa jazdy pociągów i systemem biletowym. Zarządzanie infrastruktura trakcyjną i sygnalizacyjną pozostawiono w rękach Network Rail. Pierwszymi zmianami dokonanymi przez nowych zarządców były ${ }^{11}$ :

- obsługa na każdej stacji,

- wprowadzenie karty miejskiej Oyster,

- dodatkowe kursy we wczesnych godzinach rannych i późnych wieczornych (w celu dopasowania kursów pociągów do kursowania linii metra).

Od czasu przejęcia London Overground przez TfL wprowadzono wiele udogodnień dla podróżujących. Poprawiono bezpieczeństwo na stacjach oraz poziom obsługi klientów dzięki obecności personelu na każdej ze stacji w godzinach kursowania pociągów. Umożliwiono pasażerom korzystanie z karty Oyster. Wprowadzono dodatkowe kursy we wczesnych i późnych godzinach. Podczas wakacji w 2008 r.

\footnotetext{
${ }^{10}$ www.tfl.gov.uk/corporate/modesoftransport/1558.aspx [z dn. 11.10.2012].

${ }^{11}$ www.alwaystouchout.com/project/43\#InitialImprovements [z dn. 11.10.2012].
} 
przeprowadzono gruntowne porządki na stacjach. W 2009 r. pracę rozpoczałł nowy tabor kolejowy, składający się z 54 maszyn dostarczonych przez firmę Bombardier Transportation. Pociagi posiadaja klimatyzację, szersze alejki i siedzenia. Większe drzwi umożliwiaja szybsze wysiadanie i wsiadanie, a także nie stanowia przeszkody dla osób poruszajacych się na wózkach. Pasażerowie są lepiej poinformowani dzięki komunikatom audio $w$ pociaggach.

Linia East London należąca do London Underground została zamknięta w grudniu 2007 r. w celu przebudowy, wydłużenia i wcielenia do sieci London Overground. W czerwcu 2010 r. zostały uruchomione przejazdy na pierwszym z odcinków. Pociągi kursuja z Dalston Junction na północy do New Cross, Crystal Palace i West Croydon na południu. W ramach projektu powstaja cztery nowe stacje. W lutym 2011 r. linia została przedłużona do Highbury \& Islington. W 2012 r. został ukończony zachodni odcinek z Surrey Quays do Clapham Junction - wtedy też przewidziano zakończenie projektu, mającego na celu stworzenie orbitalnego połączenia kolejowego. Linie należące do London Overground maja umożliwić przejazdy naokoło Londynu bez konieczności wjeżdżania do centrum. System połączy ze soba 20 z 33 londyńskich dzielnic. Na centralnym odcinku z Surrey Quays do Dalston Junction pociągi będa kursowały co 5 minut, czyli częstotliwość wzrośnie o 60\%. Wydłużenie linii East London przyczyni się również do rewitalizacji zapomnianych i zaniedbanych terenów na południu miasta. Rozbudowa systemu połączeń pozwoli też na obniżenie poziomu emisji $\mathrm{CO}_{2}$.

Linia North London jest jedna z 10 linii, które brały udział w obsłudze pasażerów dojeżdżających do Parku Olimpijskiego podczas Igrzysk Olimpijskich w 2012 r. Natomiast wydłużona linia East London zapewniła szybkie połączenie z południa miasta do Parku Olimpijskiego, a także pozwoliła ograniczyć kongestię na stacji London Bridge.

W ramach wspólnego projektu inwestycyjnego TfL i Westfield London na terenach White City i Shepherd's Bush, odnowie i przebudowie została poddana stacja Shepherd's Bush Overground Station. Na stacji można wsiaść w pociągi kursujące po całym kraju. Jest nowoczesna i w pełni dostępna dla osób z utrudniona mobilnością. Oprócz sieci kolejowej podróżni mogą tutaj przesiadać się na linię Central (metro), a także na autobusy i taksówki.

W 2008 r. Transport for London i Departament Transportu podpisały się pod projektem kolei podziemnej Crossrail. Prace konstrukcyjne rozpoczęły się w 2010 r. a połączenie będzie gotowe w roku 2017. Trasa będzie przebiegać z Maidenhead i Heathrow na zachodzie do Shenfield i Abbey Wood na wschodzie. Połączy ze sobą lotnisko Heathrow, 
centrum Londynu, West End i drugie centrum biznesowe Canary Wharf. Nowe połączenie będzie szybsze i łatwo dostępne. Pozwoli zredukować tłok w londyńskim systemie transportowym, a zwłaszcza na linii Piccadilly, która obecnie obsługuje lotnisko oraz na innych liniach metra w centrum miasta. Prognozuje się, że jeden pociąg w godzinach szczytu będzie przewoził ponad 1500 pasażerów. Nowe połączenie to $118 \mathrm{~km}$ trakcji i 37 stacji, z czego 8 zupełnie nowych w centrum i 28 przebudowanych oraz przystosowanych do nowego połączenia. Sercem kolei będzie 42-kilometrowy tunel w sercu miasta.

Twórcy wierza, że przedsięwzięcie przyniesie wiele korzyści ekonomicznych i pozwoli na utrzymanie wizerunku Londynu jako atrakcyjnej lokalizacji dla biznesu. Podróżujący koleją Crossrail będą mogli używać karty miejskiej Oyster, a nowe połączenie dopełni inne, już istniejące, i w pełni się z nimi zintegruje. Jedną z największych zalet będzie znacząca redukcja czasu podróży, np. teraz pokonanie trasy z Heathrow do Canary Wharf zajmuje 71 min, zaś przejechanie tej samej trasy koleja Crossrail zajmie 43 min.

\section{Podsumowanie}

W wyniku analiz przeprowadzonych w niniejszym rozdziale sformułowano następujące wnioski:

- Infrastruktura metra świadczy o jego długiej historii. Wyróżnia się dwa rodzaje taboru w zależności od tego, czy pociągi poruszaja się w głębokich tunelach (45\%), czy w najstarszych - płytkich i na powierzchni ziemi.

- Założenia programu modernizacji metra obejmuja nie tylko przystosowanie go do obsługi Igrzysk Olimpijskich w 2012 r., ale wszystkie prace zaplanowane sa tak, aby długofalowo podnieść jakość obsługi podróżnych i przystosować się do zwiększonego popytu (udział przewozów transportem zbiorowym z roku na rok się zwiększa) oraz zintegrować istniejąca sieć z nowo powstającymi połączeniami (głównie transportu szynowego).

- Przykład lekkiej kolei nadziemnej (Docklands Light Railway) pokazuje znaczenie transportu w rewitalizacji obszarów miast, a także stanowi potwierdzenie ogromnej roli transportu w podnoszeniu atrakcyjności i umożliwianiu prawidłowego funkcjonowania miasta.

- Sieć tramwajowa jest doskonałym uzupełnieniem miejskiego transportu w dzielnicach nieobsługiwanych przez linie metra. Jednocześnie 
historia tego systemu w Londynie pokazuje, że tendencja do likwidowania połączeń tramwajowych po to, aby zwiększyć miejsce na ulicach dla samochodów osobowych był ogromnym błędem planistycznym i ekonomicznym.

- Droga do tego, aby Transport for London mógł zarządzać siecią kolei metropolitarnej (London Overground) była bardzo trudna i długa, jednak obecnie pozwala to na zintegrowanie połączeń kolei z resztą środków transportu, co podnosi jej dostępność i jakość dla podróżujących oraz czyni ja prawdziwym środkiem transportu miejskiego. 



\title{
11. Plany budowy Kódzkiej Kolei Aglomeracyjnej
}

\author{
Łukasz Trzeszczak ${ }^{*}$
}

\subsection{Charakterystyka planów ŁKA}

Pierwsza koncepcja stworzenia systemu Łódzkiej Kolei Aglomeracyjnej (ŁKA) pojawiła się $\mathrm{w}$ marcu 2008 r. Pomysł ten został pozytywnie oceniony przez władze samorządowe województwa łódzkiego oraz miasta Łodzi. Głównymi argumentami przemawiającymi za jej powstaniem były:

- zjawisko migracji ludności z miasta Łodzi poza jego granice,

- rosnące zapotrzebowanie na sprawny i szybki transport w obrębie aglomeracji,

- coraz większe natężenie ruchu transportu drogowego powodujące zatory ${ }^{1}$.

Jednak bezpośrednim czynnikiem motywującym była struktura funduszy unijnych. Program Infrastruktura i Środowisko pozwalał na zarezerwowanie znacznej kwoty przeznaczonej na rozwój transportu przyjaznego środowisku $w$ największych aglomeracjach Polski². Transport szynowy jest bez wattpienia jedna z bezpieczniejszych dla środowiska form transportu, poza tym czynniki, takie jak ograniczona liczba beneficjentów czy wybrane obszary na terenie kraju wymusiły powstanie projektu, by móc w pełni wykorzystać pomoc europejską dla rozwoju Polski ${ }^{3}$.

Według wstępnych założeń ŁKA ma ruszyć w 2013 r. Założenia mówią o zakupie 20 szynobusów (18 zakupionych z Programu Operacyjnego Infrastruktura i Środowisko i dwa z Funduszu Kolejowego), które mają

*Mgr Łukasz Trzeszczak - Katedra Logistyki, Wydział Zarządzania Uniwersytetu Łódzkiego, ul. Matejki 22/26, 90-237 Łódź.

1 http://lka.lodz.pl/index.php/projekt-7-3-19-budowa-systemu-Ika-etap-1 [z dn. 11.10.2012].

${ }^{2} \mathrm{Na}$ konferencji w dniu 27 stycznia 2010 r., poświęconej realizacji projektów infrastrukturalnych realizowanych w ramach POIiŚ, ówczesny minister C. Grabarczyk oznajmił, że wielkość środków tego programu to aż 27 mld euro, z czego 19 mld będzie pochodziło z funduszy unijnych.

${ }^{3}$ www.rzecznik.dlalodzi.info/aktualnosci/286-lodzka-kolej-aglomeracyjna-buzalek [z dn. 11.10.2012]. 
obsługiwać trasy z Łodzi do Łowicza, Kutna, Zduńskiej Woli oraz Koluszek, a także linię wewnątrz miasta łączącą stację Widzew z Łodzią Kaliską. Oprócz wymienionych stacji granicznych list intencyjny podpisały władze Pabianic, Głowna, Ozorkowa, Strykowa, Łęczycy, Łasku i Zgierza. Finansowanie funkcjonowania kolei będzie zadaniem samorządów lokalnych (ma być uzależnione od liczby mieszkańców). Podpisane porozumienie zawiera informacje dotyczące budowy i modernizacji przystanków (stacji) kolejowych na liniach ŁKA oraz jej zaplecza technicznego, poprawy stanu linii kolejowych w obrębie ŁKA, a także wspierania działania tej kolei już po jej uruchomieniu. Pierwszy okres podpisanej umowy dotyczy lat 2013-20184.

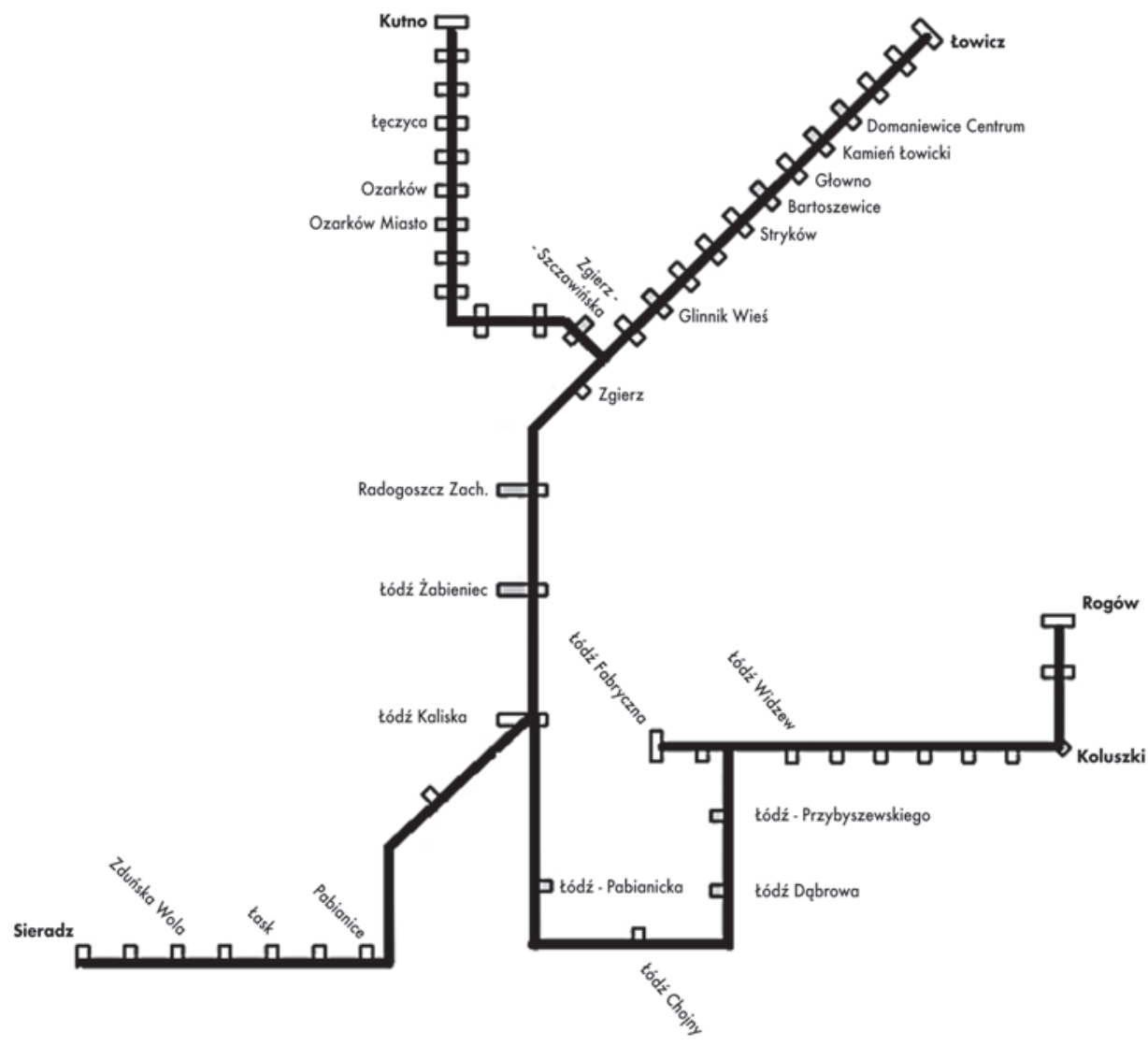

Rysunek 25. Mapa Łódzkiej Kolei Aglomeracyjnej

Źródło: opracowanie - Anna Zmysłowska

${ }^{4}$ http://logistyka.wnp.pl/lodzka-kolej-aglomeracyjna-ma-ruszyc-w-2013-roku,113716_1_0_0.html [z dn. 11.10.2012]. 
Plany zakładaja powstanie czterech głównych linii ${ }^{5}$ :

- nr 14 łączącej Łódź Kaliską z Sieradzem (ewentualnie ze Zduńską Wola, w przypadku gdyby Sieradz nie był zainteresowany inwestycja), - nr 15 łączącej Łódź Kaliską z Łowiczem,

- nr 16 łączącej Łódź Kaliską z Kutnem, - nr 17 łączącej Łódź Fabryczną z Koluszkami.

Łódzka Kolej Aglomeracyjna ma pełnić funkcję uzupełniająca dla połączeń regionalnych. Szynobusy maja mieć pojemność 160 pasażerów, ale za to ich dynamika, w porównaniu ze zwykłymi pociągami, będzie większa. Ma to zapewnić system szybszego startu oraz zatrzymywania się ${ }^{6}$.

Warunki, jakie postawiono przed szynobusami, to m.in.: nowoczesne, wysokie standardy oraz warunki techniczne, zerowy negatywny wpływ na środowisko, bezpieczeństwo ruchu pasażerskiego, funkcjonalne rozwiązania konstrukcyjne w zakresie przewozu osób niepełnosprawnych, a także bezpieczeństwo przewozu bagażu

Wedle planów właścicielem pojazdów ma być specjalnie do tego celu powołana Łódzka Kolej Aglomeracyjna Sp. z o.o., której jedynym udziałowcem będzie województwo łódzkie. Jednak zastrzeżenia budzi fakt, że wedle założeń po zakupie szynobusów spółka nie będzie brała udziału w zadaniach dotyczących eksploatacji pojazdów. Ma to być zlecone przedsiębiorstwu, które posiada uprawnienia przewoźnika kolejowego. Istnieja również obawy, iż organizatorem przewozów moga zostać Przewozy Regionalne, czyli spółka, która nie cieszy się popularnościa wśród podróżujących. Jest to o tyle dziwne, iż coraz większego znaczenia nabiera trend powstawania własnych spółek przewozowych, których zarządcami są województwa (np. Koleje Mazowieckie) ${ }^{8}$.

Projekt przewiduje, że powstałe oraz zmodernizowane dworce mają mieć charakter multimodalny. Oznacza to, iż poza pociągami będą się tam zatrzymywać autobusy komunikacji miejskiej i PKS. Wskazano też na zapotrzebowanie na duże parkingi samochodowe oraz stojaki na rowery ${ }^{9}$.

W ramach projektu ma powstać zaplecze techniczne dla taboru Łódzkiej Kolei Aglomeracyjnej. Obiekt ten usytuowany będzie w pobliżu stacji Łódź Widzew, a zajmowana przez niego powierzchnia ma

${ }^{5}$ Budowa systemu Łódzkiej Kolei Aglomeracyjnej - Etap I, s. 3.

${ }^{6} \mathrm{http}: / /$ lodz.gazeta.pl/lodz/1,35136,8080337,Szynobusem_po_po_lodzkiej_aglomeracji_Unia_doplaci.html [z dn. 8.02.2012].

7 Budowa systemu Łódzkiej Kolei Aglomeracyjnej - Etap I, s. 3.

${ }^{8}$ www.rzecznik.dlalodzi.info/aktualnosci/286-lodzka-kolej-aglomeracyjna-buzalek [z dn. 9.02.2012].

${ }^{9} \mathrm{http}: / /$ lodz.gazeta.pl/lodz/1,35153,9389347,UE_doplaci_miliony_do_remontow_ pociagow_i_przystankow.html [z dn. 8.02.2012]. 
wynosić 4,5 ha. Czynności wykonywane na terenie zaplecza będą związane z przeprowadzaniem przeglądów technicznych, naprawami oraz bieżącym utrzymywaniem poprawnego stanu taboru. $W$ ramach powstania tego obiektu niezbędna jest budowa następujących elementów infrastruktury:

- układ torów wyposażony w system rozjazdów oraz automatyczne sterowanie,

- hala technologiczna wyposażona w niezbędne specjalistyczne urządzenia,

- system myjni taboru, który będzie zaopatrzony w zamknięty obieg wody, a także we własna podoczyszczalnię ścieków,

- układ drogowy wyposażony w miejsca parkingowe i rampy podjazdowe, - stanowiska utrzymania czystości w taborach.

Plany przewiduja, iż obiekt będzie gotowy do eksploatacji do końca $2014 r^{10}$

Projekt ŁKA obejmuje również budowę i modernizację przystanków. Nowo wybudowane przystanki powstana m.in. w Bratoszewicach, Domaniewicach (Domaniewice Centrum), Zgierzu (Zgierz Jaracza) oraz w Łodzi (Radogoszcz Wschód, Pabianicka, Dąbrowa). Przebudowa dotyczyć będzie przystanków w Strykowie, Głownie, Zgierzu, Grotnikach i Chociszewie ${ }^{11}$.

Celami wyróżnionymi w projekcie budowy ŁKA sa ${ }^{12}$ :

1. Wzrost poziomu jakości oraz efektywności przewozów.

2. Niezawodność, punktualność oraz większa częstotliwość kursowania pociągów.

3. Skrócenie czasu podróżowania.

4. Wzrost poziomu bezpieczeństwa, a tym samym zmniejszenie ryzyka wypadków.

5. Obniżenie kosztów aktualnego utrzymania taboru.

6. Polepszenie stanu ochrony środowiska w obrębie linii.

7. Poprawa wygody podróżnych.

8. Eliminacja barier architektonicznych oraz przystosowanie obiektów i taboru dla osób niepełnosprawnych.

9. Otwarcie szerokich możliwości przestrzennych.

Korzyści płynace z powstania ŁKA maja głównie charakter społecznogospodarczy, środowiskowy oraz dotyczący zrównoważonego rozwoju.

${ }^{10}$ http://lka.lodz.pl/index.php/projekt-7-3-19-budowa-systemu-Ika-etap-1/zaplecze [z dn. 9.02.2012].

11 http://lodz.gazeta.pl/lodz/1,35153,9885561,Szynobusem_po_regionie_pojedziemy_z_nowych_przystankow.html [z dn. 9.02.2012].

${ }^{12}$ Budowa systemu Łódzkiej Kolei Aglomeracyjnej - Etap I, s. 8. 
Do tych pierwszych można zaliczyć podniesienie efektywności całego systemu transportowego w regionie i wyrównanie szans rozwoju dla ludności spoza ośrodków silnie zurbanizowanych. Aspekty środowiskowe to przede wszystkim spełnienie norm unijnych w zakresie dbałości o przyrodę, a także sprawne ominięcie wszelkich obszarów, które podlegają ochronie. Jeżeli zaś chodzi o zrównoważony rozwój, to nadrzędną założoną korzyścia jest zahamowanie spadku liczby osób poruszających się za pomoca kolei - dzięki poprawie jej dostępności oraz „stworzeniu atrakcyjnego, nowoczesnego i mobilnego łańcucha podróży, dostępnego dla różnych grup użytkowników komunikacji, wykorzystującego intermodalność, zalety transportu szynowego: wysoką prędkość komunikacyjną w obszarze zurbanizowanym, węzły przesiadkowe, atrakcyjny system informacji pasażerskiej"13.

Według autorów projektu budowy Łódzkiej Kolei Aglomeracyjnej, wpłynie ona na atrakcyjność inwestycyjną województwa łódzkiego w takich aspektach, jak:

1. „Poprawa spójności aglomeracji i regionu.

2. Poprawa mobilności pracowników w aglomeracji i regionie.

3. Otwarcie nowych terenów inwestycyjnych w województwie łódzkim.

4. Poprawa dostępu mieszkańców województwa łódzkiego do infrastruktury miasta Łodzi (szpitale, muzea, stadiony, urzędy itp.).

5. Poprawa oferty turystycznej w regionie.

6. Poprawa infrastruktury kolejowej wraz z infrastruktura towarzysząca"14.

\section{2. ŁKA a inne inwestycje $w$ regionie}

Równolegle z powstawaniem Łódzkiej Kolei Aglomeracyjnej, na terenu regionu łódzkiego prowadzone sa inne inwestycje majace na celu poprawienie atrakcyjności tego obszaru. Projekty te w dużej mierze dotyczą infrastruktury transportowej, jednakże istnieją również przedsięwzięcia o innym charakterze ${ }^{15}$.

Inwestycja majaca znaczenie krajowe jest budowa ringu autostradowego wokół Łodzi. Jest to szereg dróg i autostrad, które pozwola

13 http://lka.lodz.pl/index.php/projekt-7-3-19-budowa-systemu-lka-etap-1/cele -i-korzysci-projektu [z dn. 8.02.2012].

${ }^{14}$ Budowa systemu Łódzkiej Kolei Aglomeracyjnej - Etap I, s. 12.

${ }^{15}$ Do takich przedsięwzięć zalicza się węzeł autostradowy Stryków, który - jak podkreślał minister C. Grabarczyk - jest drugim co do wielkości tego typu obiektem w Polsce. 
odciążyć miasto z ruchu samochodowego. Od północy metropolia będzie zamknięta autostrada A2, od wschodu autostrada A1, od południa droga ekspresowa S8, a od zachodu droga ekspresowa S14. Ma to duże znaczenie, gdyż obecnie Łódź postrzegana jest przez kierowców jako jeden wielki korek. Przez centrum miasta przebiega bowiem m.in. droga krajowa nr 1 (łącząca Cieszyn z Gdańskiem) oraz nr 14 (łącząca Walichnowy $z$ Łowiczem). Zakończenie prac i otwarcie w pełni sprawnego pierścienia drogowego wokół Łodzi przewidywane jest na rok 2015 (rys. 26). C. Grabarczyk podkreśla, że gdy on pełnił funkcję ministra infrastruktury, duże inwestycje strukturalne przestały omijać region łódzki, który jest kluczowy, jeśli chcemy mieć dobrze skomunikowany kraj.

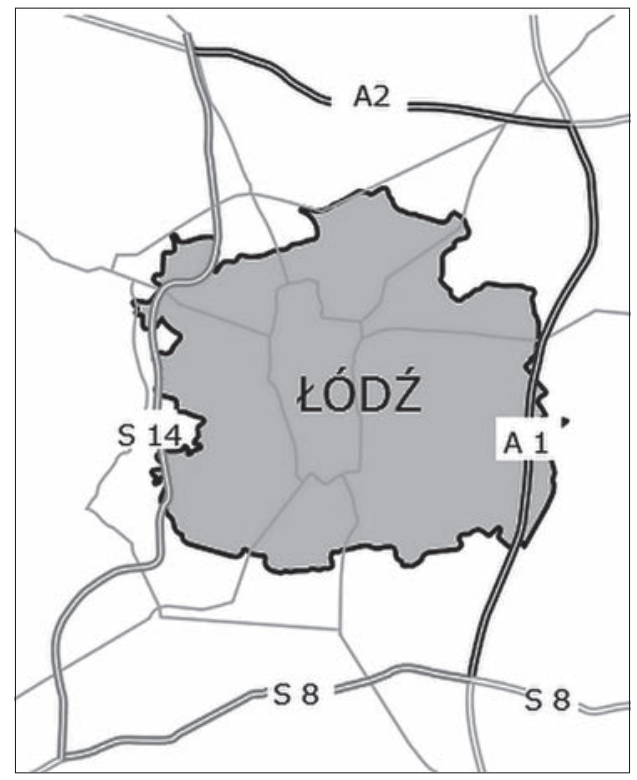

Rysunek 26. Ring autostradowy

Źródło: opracowanie - Anna Zmysłowska

Warto wspomnieć, iż w fazie planowania A1 oraz S14 dochodziło do licznych protestów ze strony mieszkańców. Najczęściej dotyczyły one przebiegu tras, a nadrzędnym problemem stały się wysiedlenia mieszkańców z budynków przeznaczonych do wyburzenia ${ }^{16}$.

${ }^{16}$ K. Dmochowska-Dudek, Konflikty społeczne wokół inwestycji w Łódzkim Obszarze Metropolitalnym, [w:] A. Jewtuchowicz, M. Wójcik (red.), Łódzka metropolia. Problemy integracji gospodarczej, Wyd. Biblioteka, Łódź 2010, s. 63-65. 
Kolejną inwestycja o znacznych rozmiarach jest przebudowa Dworca Fabrycznego. To część projektu związanego z modernizacją linii kolejowych Warszawa-Łódź oraz odcinka Łódź Widzew-Łódź Fabryczna. Cały projekt figuruje pod nazwą POIiŚ 7.1-24.2. W jego skład wchodza:

- budowa tunelu z czterotorową linia, na której będzie prowadzony ruch dalekobieżny, aglomeracyjny, regionalny i kolei dużych prędkości,

- budowa stacji podziemnej Łódź Fabryczna,

- budowa konstrukcji dworcowej Łódź Fabryczna,

- budowa podziemnego przystanku dla stacji Łódź Niciarniana,

- przebudowa stacji Łódź Widzew, który będzie posiadał m.in. 6 torów przeznaczonych na ruch pasażerski,

- inne działania związane z ruchem pieszym oraz infrastruktura teleinformatyczna ${ }^{17}$.

Resort C. Grabarczyka zaplanował realizację tej inwestycji w podziale na etapy. W pierwszym z nich zostanie zbudowany dworzec podziemny Łódź Fabryczna i połączony tunelem z dworcem Łódź Widzew. W drugim etapie zbudowane będa tunele do dworca Łódź Kaliska, zarówno dla kolei tradycyjnej, jak i KDP.

Oprócz wymienionych działań w zakresie transportu kolejowego projekt zawiera także inwestycje związane z przekształceniem dworca Łódź Fabryczna w obiekt multimodalny. Dlatego też przewiduje się budowę trzykondygnacyjnego parkingu podziemnego, przystanków autobusowych dla komunikacji międzymiastowej, znajdujących się również pod powierzchnią ziemi oraz budowę drogi dojazdowej do tego węzła. Wzięto też pod uwagę modernizację linii tramwajowych wraz z przystankami, powstanie przystanków dla komunikacji miejskiej i parkingów typu Park \& Ride oraz przeznaczonych dla rowerów ${ }^{18}$.

Dworzec podziemny Łódź Fabryczna na głębokości 16 metrów będzie posiadał 4 perony (jeden przeznaczony dla kolei dużych prędkości). Kasy biletowe i sala odpraw będą usytuowane 8 metrów wyżej, a w części nadziemnej, która może posiadać 6 kondygnacji, znajdować się będą budynki przeznaczone na działalność komercyjna ${ }^{19}$.

Inwestycją powiązaną z powstaniem podziemnego dworca Łódź Fabryczna jest budowa tunelu średnicowego pod Łodzią. Miałaby ona połączyć Łódź Fabryczna z Łodzią Kaliską. W Studium wykonalności budowy linii kolejowej na odcinku od dworca Łódź Fabryczna w kierunku dworca

17 http://www.plk-inwestycje.pl/inwestycje/program-operacyjny-infrastruktura-i-srodowisko/poiis-71-242 [z dn. 10.02.2012].

${ }^{18}$ Nowe Centrum Łodzi oraz Łódzki Węzeł Kolejowy, s. 29.

19 J. Gałuszka, Idee i cele przebudowy centrum Łodzi w kontekście społeczno-przestrzennej specyfiki miasta, [w:] J. Gałuszka (red.), Wokół Nowego Centrum Łodzi, EC1 - Miasto Kultury, Łódź 2010, s. 20. 
Łódź Kaliska zarekomendowano wariant I, który dla kolei dużych prędkości prowadzony jest na styku z hala widowiskową Atlas Arena. Dla kolei konwencjonalnych wariant "poprowadzony jest po wyjściu z północnej części głowicy rozjazdowej projektowanej stacji Łódź Fabryczna pod centrum miasta w kierunku północno-zachodnim, w rejon ulic Ogrodowej/ Karskiego/Drewnowskiej. W tym rejonie została zlokalizowana stacja pośrednia. Za nią następuje odchylenie w kierunku zachodnim. Tu następuje rozgałęzienie tuneli, mające na celu umożliwienie kierunkowych i bezkolizyjnych włączeń do linii nr 15 Bednary-Łódź Kaliska. Ma to miejsce na odcinku prostym szlaku Łódź Żabieniec-Łódź Kaliska"20.

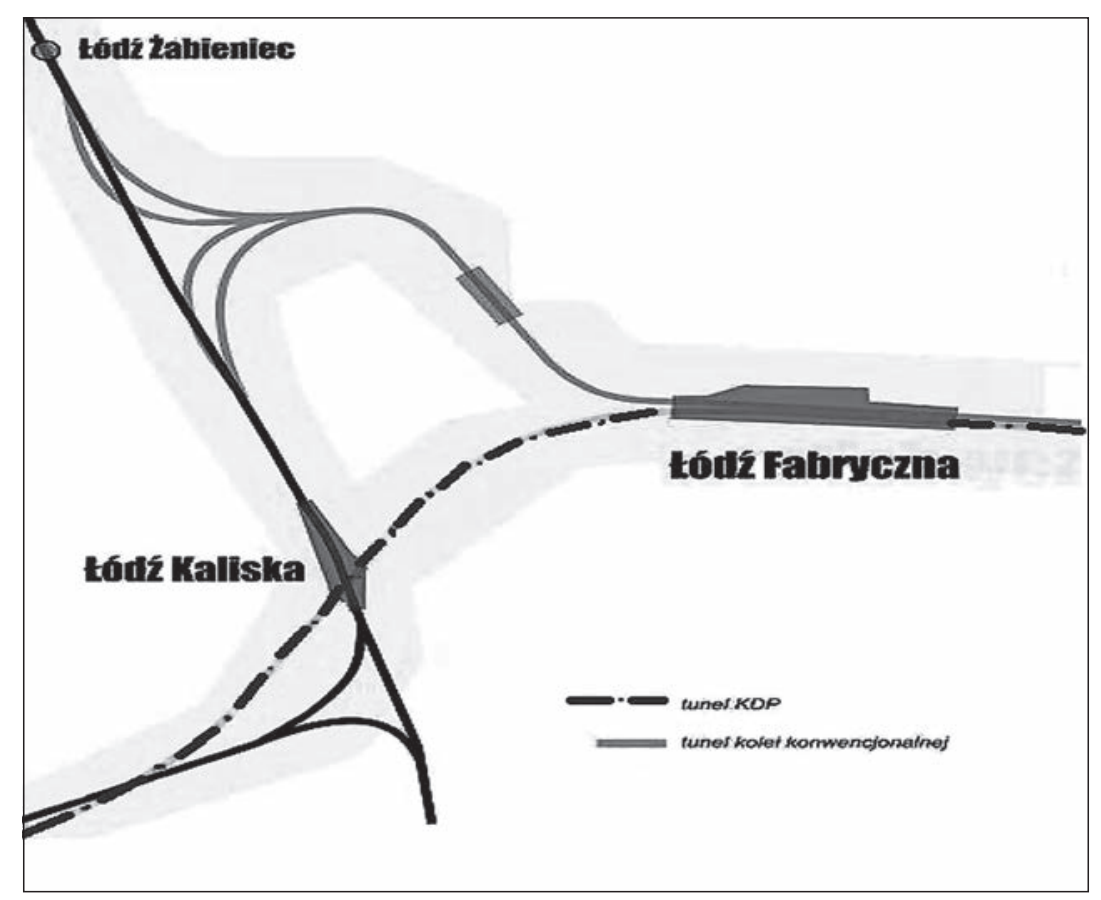

Rysunek 27. Mapa przedstawiająca przebieg tuneli średnicowych pod Łodzią Źródło: opracowanie - Anna Zmysłowska

W wybranym wariancie łączna długość linii wynosi $11050 \mathrm{~m}$ dla linii zwykłych oraz 11300 m dla linii KDP, natomiast długość tuneli przedstawia się odpowiednio: $8257 \mathrm{~m}$ i $5100 \mathrm{~m}$. Prędkości maksymalne w tunelach to $160 \mathrm{~km} / \mathrm{h}$ dla KDP oraz $100 \mathrm{~km} / \mathrm{h}$ dla linii konwencjonalnych ${ }^{21}$.

${ }^{20}$ Projektowane linie średnicowe $w$ Łodzi jako element systemu KDP oraz kolei konwencjonalnych - prezentacja ustaleń studium wykonalności, Warszawa-Łódź, grudzień 2011, s. 7.

${ }^{21}$ Tamże, s. 9. 
Na początku 2012 r. wspólne działania samorządów województwa i miasta przy wsparciu C. Grabarczyka doprowadziły do przygotowania studium wykonalności tuneli średnicowych pod Łodzia.

Zaletami, które miały wpływ na wybór takiego przebiegu linii kolei dużych prędkości są m.in.: przebieg dużej części tras w korytarzach niezabudowanych lub zajętych już do celów transportowych, najkrótsza długość tuneli w porównaniu z innymi wariantami, wyeliminowanie skrzyżowań z trasami tuneli kolei zwykłych, zminimalizowanie styczności z ruchem samochodowym. Jeżeli chodzi o czynniki mające na wpływ na trasę linii konwencjonalnych, były to: bezpośrednie połączenie najbardziej znaczących ośrodków aglomeracji łódzkiej (Łódź Widzew, Łódź Fabryczna, Manufaktura, Atlas Arena, stadion miejski, a także ewentualnie w przyszłości rejon Portu Lotniczego), minimalizacja liczby koniecznych skrzyżowań z innymi trasami kolejowymi, brak zakłóceń w przypadku rozbudowy stacji Łódź Kaliska, stacja pośrednia zlokalizowana w pobliżu centrum handlowego Manufaktura pozwoli na powstanie dogodnych warunków obsługi pasażerów dojeżdżających z innych miast lub innych rejonów miasta, czego efektem może być zmiana struktury dominującej gałęzi transportu w tej części Łodzi ${ }^{22}$.

Inwestycja, która ma na celu poprawienie kulturowego wizerunku Łodzi jest budowa Nowego Centrum Łodzi. Geneza pomysłu to poszukiwania obiektów pofabrycznych, które mogłyby stać się centrum sztuki. Idealna do tego celu okazała się nieczynna elektrociepłownia EC1. Z upływem czasu idea zaczęła się rozrastać i od jednego obiektu urosła do planów stworzenia "dzielnicy kultury". Przeniesienie Dworca Fabrycznego pod powierzchnię ziemi oraz budowa tunelu średnicowego pozwoli na wyodrębnienie ogromnego obszaru, który stanie się terenem nowych inwestycji. Nowe Centrum Łodzi będzie ograniczone ulicami Narutowicza, Sienkiewicza, Tuwima oraz Kopcińskiego. Plany zakładaja podzielenie obszarów na dwie strefy: pierwsza z nich, obejmująca ok. 30 ha, to skupisko działań kulturalnych. Pozostałe 50 ha będzie przeznaczone na inwestycje komercyjne ${ }^{23}$.

W ramach powstającego Nowego Centrum Łodzi funkcje kulturalne będa pełnić24:

- EC1 Zachód - powstanie tutaj ośrodek muzealno-edukacyjno-naukowy,

- EC1 Wschód - obiekty kulturalno-artystyczne,

- EC1 Południowy Wschód - wytwórnia filmów rysunkowych SE-MA-FOR, a także Muzeum Bajki,

22 Tamże, s. 10-14.

23 J. Gałuszka, Idee i cele przebudowy centrum Łodzi.., s. 13-16.

24 Tamże, s. 16-20. 
- Specjalna Strefa Sztuki, Specjalna Strefa Kultury oraz Ulice Czterech Kultur,

- Centrum Festiwalowo-Kongresowe.

\subsection{Etapy uruchomienia ŁKA}

W czerwcu 2008 r. została przedstawiona Koncepcja rozwoju transportu kolejowego w regionie łódzkim do 2030 roku. Łódzką Kolej Aglomeracyjna ukazano w niej jako kluczowy element systemu kolejowego w regionie łódzkim. W październiku tego samego roku Zarząd Województwa Łódzkiego zadecydował o zainicjowaniu prac studialnych dotyczących projektu. Jednym z czynników było pojawienie się możliwości sfinansowania projektu ze środków Programu Operacyjnego Infrastruktura i Środowisko - działanie 7.3. W grudniu roku 2008 opracowano Strategię rozwoju transportu pasażerskiego w regionie łódzkim, w której ujęto zakres terytorialny przeznaczony dla kolei aglomeracyjnej, a także jej zadania w wojewódzkim systemie transportowym ${ }^{25}$.

Również w 2008 r. Urząd Marszałkowski zadecydował o rozpoczęciu projektu dotyczącego Budowy systemu Łódzkiej Kolei Aglomeracyjnej - Etap I. Jest to początkowy etap powstania systemu transportu szynowego, który swoim zasięgiem ma objąc aglomerację łódzka, wiążąc ją z następującymi systemami:

- regionalnym w obrębie województwa łódzkiego,

- ponadregionalnym, do którego zaliczana jest planowana kolej dużych prędkości,

- regionalnym oraz miejskim tramwajem ${ }^{26}$.

Studium wykonalności Budowy systemu Łódzkiej Kolei Aglomeracyjnej - Etap I zostało rozpoczęte w marcu 2009 r., a jego koniec przypadł na pierwszy kwartał roku następnego. Potwierdziła się ekonomiczna efektywność przedsięwzięcia i jego celowość. W analizie dotyczącej finansów uznano, iż do realizacji projektu niezbędne jest wsparcie funduszy publicznych, w tym skorzystanie z Funduszu Spójności.

W czerwcu 2010 r. został złożony wniosek o dofinansowanie projektu w ramach Programu Operacyjnego Infrastruktura i Środowisko na lata 2007-2013 (numer 7.3-19). Przedmiotem był zakup niezbędnego taboru. W roku następnym skorzystano z możliwości poszerzenia

${ }^{25}$ www.lka.lodzkie.pl/index.php/projekt-7-3-19-budowa-systemu-lka-etap-1 [z dn. 12.02.2012].

${ }^{26}$ OPZ Budowa tunelu kolei średnicowej $w$ Łodzi, s. 7. 
zakresu dofinansowana i do elementów wymagających wsparcia dołaczono budowę zaplecza technicznego ${ }^{27}$.

Wartość wydatków kwalifikowalnych projektu została obliczona na 327724000 zł, natomiast wnioskowana wysokość dofinansowania ze środków Unii Europejskiej to 193357160 zł²8.

Budowa Łódzkiej Kolei Aglomeracyjnej, będącej główną częścią zintegrowanego transportu zbiorowego na obszarze łódzkim, została podzielona na 3 etapy ${ }^{29}$.

I etap, oprócz zakupu taboru oraz budowy zaplecza technicznego, przewiduje uruchomienie regularnych przewozów w latach 2014-2015. Do szczegółowych założeń należą:

- wprowadzanie do eksploatacji zakupionego taboru (będzie się to odbywało etapami według harmonogramu dostaw, które następować maja od kwietnia 2013 r. do I kwartału roku 2015 r.),

- oferta 18 par pociągów na trasie Łódź Fabryczna-Koluszki oraz 12 par Przewozów Regionalnych (częstotliwość z pociaggami PR - co 30 min),

- na odcinku Łódź Kaliska-Sieradz 21 par pociągów i 6 par składów Przewozów Regionalnych (kursujących w szczycie co 30 min, poza nim - co 60 min),

- odcinek Łódź Kaliska-Kutno obsługiwany przez 15 par pociągów (w szczycie kursujacych w odstępie $30 \mathrm{~min}$, poza nim - co $120 \mathrm{~min}$ ), - na odcinku Łódź Kaliska-Łowicz 19 par pociągów (kursujących co godzinę),

- odcinek linii Łódź Widzew-Łódź Kaliska obsługiwany przez 8 par pociągów (odjeżdżających co 2 godziny).

Harmonogram przewozów uruchamianych w ramach ŁKA kształtuje się następująco: linia Łódź Fabryczna-Koluszki ma zostać uruchomiona do stycznia 2014 r., linia Łódź Kaliska-Kutno do kwietnia 2014 r., linia Łódź Kaliska-Łowicz do końca roku 2014, a linia Łódź KaliskaSieradz do kwietnia 2015 r.

Założono również, iż zostanie przejęte (głównie od Przewozów Regionalnych) 488 tys. pociągokilometrów (pockm) ${ }^{30}$.

27 www.lka.lodzkie.pl/index.php/projekt-7-3-19-budowa-systemu-lka-etap-1 [z dn. 12.02.2012].

${ }^{28}$ http://www.Ika.lodzkie.pl/index.php/projekt-7-3-19-budowa-systemu-lkaetap-1/zakresprojektu [z dn. 12.02.2012].

${ }^{29}$ Dalsza część podrozdziału została opracowana na podstawie materiałów zamieszczonych na oficjalnej stronie internetowej Łódzkiej Kolei Aglomeracyjnej Sp. z o.o. http:// Ika.lodz.pl [z dn. 12.02.2012].

30 Pociągokilometr - jednostka miary pracy eksploatacyjnej linii kolejowej, odpowiadająca przemieszczeniu się jednego pociągu na dystansie jednego kilometra (http:// pl.wikipedia.org). 
II etap budowy systemu Łódzkiej Kolei Aglomeracyjnej kładzie nacisk na rozwój istniejących sieci połączeń. Ma to mieć miejsce głównie dzięki ustabilizowaniu podsystemu przejazdów aglomeracyjnych oraz inwestycjom wykonanym w ramach Regionalnego Programu Operacyjnego województwa łódzkiego w latach 2014-2020.

Do zadań wskazanych do realizacji w etapie II zalicza się:

- podniesienie efektywności wykorzystania taboru poprzez skrócenie czasu jazdy na trasie Łódź Kaliska-Sieradz, a także budowę dwutorowych odcinków na linii nr 15 (Łódź Kaliska-Łowicz),

- na linii Łódź Fabryczna-Koluszki podniesienie liczby par pociągów ŁKA do ilości 35, dzięki czemu częstotliwość ich kursowania w dni robocze wyniesie $30 \mathrm{~min}$,

- na odcinku Łódź Kaliska-Sieradz wzrost liczby par pociągów ŁKA do 25 po 2023 r. - pozwoli to na wydłużenie godzin szczytu, w którym częstotliwość kursów będzie wynosić 30 min,

- na linii Łódź Kaliska-Łowicz od roku 2022 kursować ma 25 par pociągów; zwiększy to częstotliwość ich przejazdów w szczycie (co 30 min),

- na lata 2021-2025 zakładany jest wzrost prac eksploatacyjnych Łódzkiej Kolei Aglomeracyjnej, która docelowo w roku 2025 ma wynieść 3325 tys. pockm. Poziom prac eksploatacyjnych Przewozów Regionalnych kształtować ma się na poziomie 3150 tys. pociagokilometrów.

Ponadto według OPZ Budowa tunelu kolei średnicowej $w$ Łodzi na lata 2014-2020, w ramach drugiego etapu budowy ŁKA ma powstać tunel średnicowy łączący Łódź Fabryczna z Łodzią Kaliską. Zaplanowane jest także powstanie węzłów intermodalnych w celu zwiększenia integralności kolei aglomeracyjnej z innymi systemami transportowymi miejscowości w aglomeracji łódzkiej oraz ponadregionalnymi sieciami transportowymi ${ }^{31}$.

W projekcie zarówno etapu I, jak i II znalazł się zapis dotyczący rezerwy "na wykonanie pracy eksploatacyjnej wybranych kursów na lotnisko Lublinek lub na innej linii komunikacyjnej w Łodzi"32. Połączenie z Portem Lotniczym ma nabrać dużego znaczenia w przypadku wybudowania tunelu średnicowego pod Łodzią. Pojawiaja się również głosy, by w okolicach lotniska kończyły swoje trasy pociągi międzyregionalne, co pozwoliłoby mu nadać większe niż obecnie znaczenie.

III etap budowy $Ł K A$ jest etapem docelowym, w trakcie którego kolej aglomeracyjna kursować ma na podstawowych odcinkach w odstępie $30 \mathrm{~min}$. Do podstawowych tras należeć będą połączenia z Łodzi

${ }^{31}$ OPZ Budowa tunelu kolei średnicowej $w$ Łodzi, s. 7.

32 http://Ika.lodz.pl/index.php/projekt-7-3-19-budowa-systemu-lka-etap-1/ plan-rozwoju [z dn. 12.02.2012]. 
do Sieradza, Koluszek i Łowicza. Częstotliwość w kierunku Kutna ma wynieść co godzinę.

Wskazano również na szczególna konieczność rozwoju linii obwodowych w granicach miasta Łodzi, głównie Łódź Widzew-Łódź Kaliska, oraz powstałej linii prowadzacej do Portu Lotniczego im. Władysława Reymonta, w celu poprawy znaczenia miasta.

Podano również przewidywane poziomy prac eksploatacyjnych w roku 2026. Dla ŁKA ma on wynosić 3727 tys. pockm, zaś dla Przewozów Regionalnych 3150 tys. pockm.

\subsection{Identyfikacja czynników zagrażających budowie ŁKA}

Projekt budowy Łódzkiej Kolei Aglomeracyjnej jest rozległy. Przewiduje m.in. zakup niezbędnych pojazdów, budowę oraz modernizację infrastruktury, zarówno punktowej, jak i liniowej, a także w późniejszym czasie odpowiednie zarządzanie powstała inwestycja. W związku z tym na każdym z etapów należy spodziewać się problemów, jakie zazwyczaj występuja przy realizacji różnego rodzaju inicjatyw.

Pomysł ŁKA obejmuje swoim zasięgiem ogromną powierzchnię w obrębie aglomeracji. Trudności na tym poziomie moga objawić się w ustaleniu własności gruntów. O ile w przypadku infrastruktury liniowej szanse na to są znikome, ponieważ kolej będzie korzystać z istniejaccych torów, to w przypadku rozbudowy, a w szczególności powstawania nowych przystanków (czy też w późniejszym czasie dworców) problem ten może znacznie opóźnić czas zakończenia projektu. Przeszkody tego typu pojawiaja się w zasadzie w każdym z projektów, który swoim zakresem wymusza odbieranie ziemi będacej w posiadaniu osób prywatnych. Zdarzają się protesty prowadzące do konfliktów społecznych, tak jak miało to miejsce w województwie łódzkim podczas budowy odcinka autostrady A1 (węzeł Brzeziny-węzeł Romanów), a także powstawania Zachodniej Obwodnicy Łodzi (S14). Wtedy to mieszkańcy niezadowoleni z przebiegu tras, co wiazało się z koniecznościa opuszczenia przez nich swoich gospodarstw, słali zawiadomienia do prokuratury czy też zakładali stowarzyszenia, w ramach których bronili swoich racji33.

Problemem wynikającym z konfliktów społecznych są opóźnienia w realizowanych inwestycjach. Ma to miejsce wtedy, gdy prywatni właściciele gruntów nie godzą się na proponowane ceny, licząc na wyższy

${ }^{33}$ K. Dmochowska-Dudek, Konflikty społeczne wokół inwestycji.., s. 61. 
zysk, a to przekłada się na dodatkowe koszty, którymi obciążani są inwestorzy34.

W przypadku inwestycji wymagających dużych nakładów finansowych mogą pojawić się trudności związane z organizacją przetargów i wykorzystaniem funduszy. Jak wiadomo, Łódzka Kolej Aglomeracyjna finansowana będzie zarówno ze środków Unii Europejskiej35, jak i funduszy samorządów. Dlatego należy zwrócić baczną uwagę na ich efektywne wykorzystanie, aby instytucja zajmująca się ich rozliczaniem nie miała nawet najmniejszych zastrzeżeń. Gdyby nastapiła konieczność zwrotu choćby części funduszy europejskich, mogłoby to oznaczać liczne opóźnienia. Warto też przyjrzeć się kondycji finansowej oraz zabezpieczeniom przedsiębiorstw startujących w przetargach, by nie pojawiły się problemy, jakich świadkami była Polska podczas budowy autostrady A2. Kolejna kwestia jest sytuacja, gdy firmy, których oferty przegrywaja, składają odwołania, co nie pozwala rozpocząć prac i wpływa na następne opóźnienia.

Inne ewentualne problemy dotyczyć moga modernizacji infrastruktury. Nieprawidłowo przeprowadzone modyfikacje, a także niskiej jakości środki użyte do przebudowy moga powodować liczne zagrożenia, na które spółka ŁKA nie może sobie pozwolić w kontekście dbania o bezpieczeństwo osób korzystających z transportu zbiorowego. Pojawiły się również trudności z peronami, gdyż ich wysokość nie została dopasowana do potrzeb osób niepełnosprawnych. W Polsce standardy pozwalają na dwie wysokości peronów, które liczone są od główki szyny. Są to $55 \mathrm{~cm}$ oraz $76 \mathrm{~cm}$. Do realizacji wybrano te pierwsze, co jest dziwnym posunięciem, biorąc pod uwagę, iż podłoga szynobusów umiejscowiona będzie na wysokości $76 \mathrm{~cm}$. Spowoduje to konieczność używania specjalnych wind przez osoby poruszające się na wózkach inwalidzkich, a także wprowadzi trudności dla osób podróżujących z rowerami czy też wózkami. Autorzy tego rozwiązania nie zdecydowali się na jego zmianę (pomimo protestów ze strony stowarzyszeń zajmujących się wyrównywaniem szans dla osób niepełnosprawnych), tłumacząc to "intensywnym przewozem przesyłek towarowych"36.

Kontynuując watek infrastruktury, należy wspomnieć o tym, iż Łódzka Kolej Aglomeracyjna to nie tylko połączenia między miastami aglomeracji łódzkiej. Nie należy zapominać o takich kwestiach,

34 Tamże, s. 67.

${ }^{35}$ Dnia 27 sierpnia 2012 r. w obecności wicemarszałka Sejmu RP C. Grabarczyka podpisano umowę, na mocy której możliwe stało się dofinansowanie budowy ŁKA ze środków POIiś.

${ }^{36}$ www.rynek-kolejowy.pl/26334/LKA_Perony_beda_za_niskie.htm [z dn. 22.03.2012]. 
jak parkingi i wiaty rowerowe przy dworcach i przystankach, bezpieczne przejścia przez tory dla pieszych oraz przejazdy dla samochodów. Zwiększenie liczby połączeń po istniejacych, przebiegających w tych samych miejscach torach może doprowadzić do niebezpiecznych sytuacji. Natomiast brak miejsc, w których pasażerowie mogliby zostawiać swoje pojazdy, wpłynie negatywnie na liczbę osób korzystających $z$ ŁKA.

Z powodu trudnej do oszacowania ilości pasażerów, niełatwym zadaniem może okazać się wybór odpowiednich szynobusów. Wstępne informacje wskazuja na zakup dwuczłonowych pojazdów, które jednak w praktyce (godziny szczytu na najczęściej uczęszczanych trasach) moga okazać się niewystarczające. Zła decyzja w tym przypadku może oznaczać odpływ pasażerów, co z kolei przełoży się na mniejsze wpływy z biletów, zaś efektem końcowym stanie się nierentowność projektu.

Kolejny problem, na jaki napotyka ŁKA, wiąże się z faktem, iż przez pierwsze 5 lat jej funkcjonowania samorządy miast uczestniczących w projekcie zmuszone będa przeznaczać na nią ogromne kwoty. Sumy te uzależnione będa od liczby mieszkańców i według przewidywań np. Łask w roku 2013 zobligowany będzie do wpłaty 520 tys. zł, natomiast Zduńska Wola - ponad 1,2 mln zł. W 2018 r. sumy te będa wynosić odpowiednio: 200 tys. zł oraz ponad 500 tys. $z \nmid 37$.

Właśnie opłaty, do regulowania których zmuszone były miasta, nie pozwoliły na pełne uruchomienie Łódzkiego Tramwaju Regionalnego, który w założeniu miał połączyć Łódź ze Zgierzem i Pabianicami. Obecnie jest to linia, która kursuje w granicach miasta Łodzi, co też nie uprawnia jej do zasadnego korzystania ze swojej nazwy. Warto zwrócić uwagę, czy inwestycja tak długoterminowa, jaka jest ŁKA nie natrafi na podobne trudności, tym bardziej, że sytuacja finansowa m.in. Pabianic jest niezadowalajacca. O ile w przypadku ŁTR Pabianice były stacja końcowa, to $w$ odniesieniu do ŁKA jest inaczej, co może mieć poważne konsekwencje dla całego projektu Łódzkiej Kolei Aglomeracyjnej.

Znaczącym problemem dla ŁKA byłoby także jej zamknięcie w istniejących granicach, przez co np. Sieradz, który jest istotnym ośrodkiem województwa łódzkiego, zostałby pozbawiony dobrego połączenia z reszta aglomeracji. Jest to o tyle dziwne, iż miasto to znajduje się w odległości ok. 15 km od Zduńskiej Woli, która do projektu ŁKA należy. Urząd Marszałkowski tłumaczy, iż Sieradz nie kwalifikuje się do aglomeracji łódzkiej. Lecz to rodzi pytania, czy Kutno, które położone jest

${ }^{37}$ www.dzienniklodzki.pl/artykul/278828,lodzka-kolej-aglomeracyjna-nie-przewidujesieradza, id,t.html [z dn. 22.03.2012]. 
w podobnej odległości i do którego szynobusy będą dojeżdżać, należy do tej aglomeracji? ${ }^{38}$

Istotnym zagrożeniem w okresie funkcjonowania Łódzkiej Kolei Aglomeracyjnej będzie brak odpowiedniej siatki połączeń oraz synchronizacji z istniejącym systemem komunikacyjnym. Zła organizacja tych zadań może nie pozwolić na pełne wykorzystanie potencjału, jaki posiada opisywany projekt. Co więcej, skupienie się na wybranych połączeniach (np. takie dopasowanie siatki połączeń, by pierwszeństwo miały połączenia wewnattr Łodzi) i gorsze traktowanie pozostałych będzie rodzić poczucie niesprawiedliwości wśród pasażerów oraz miast uczestniczących w projekcie, co w istocie może doprowadzić do niesatysfakcjonujących wyników finansowych.

\subsection{Propozycje zniwelowania zagrożeń}

Aby zminimalizować potencjalne zagrożenia, niezbędne są działania wdrażane od samego początku istnienia projektu. Odpowiednie planowanie przez kompetentne, przygotowane do tego osoby służy niwelowaniu zagrożeń, które mogłyby znacząco wpłynąć na termin zakończenia budowy ŁKA czy spowodować zwiększenie kosztów. Dlatego, zdaniem autora, faza planowania ma największe znaczenie, jeśli chodzi o eliminację problemów. Już na tym etapie można przewidzieć, gdzie wystapią "wąskie gardła”, jakie sytuację moga wpłynąć na opóźnienia, co może spowodować wzrost kosztów. W tej fazie należy położyć nacisk na tak ważne w logistyce spojrzenie kompleksowe, które pozwoli na uzyskanie jak najlepszych efektów przy możliwie jak najmniejszych nakładach finansowych. Warto także skorzystać z doświadczeń osób biorących udział w podobnych projektach - jak np. twórcy oraz osoby zarządzające systemami S-Bahn w aglomeracji Berlina. Częstotliwość kursowania pojazdów w Berlinie jest dużo większa niż zakładane częstotliwości w Łodzi, a obłożenie pasażerami na każdej z tras jest ogromne. Sukces, jaki odnosi niemiecka kolej aglomeracyjna jest na pewno godnym przykładem do naśladowania ${ }^{39}$.

Czerpiąc doświadczenia od strony niemieckiej, należy wziąć pod uwagę, iż podmiot zarządzający S-Bahn przewiduje możliwość wydłużenia istniejących linii, tak by mogły one ułatwić transport miejscowościom leżącym poza granicami aglomeracji berlińskiej ${ }^{40}$. To pokazuje,

\footnotetext{
38 Tamże.

${ }^{39}$ http://inforail.pl/text.php?id=21960 [z dn. 23.03.2012].

40 Tamże.
} 
że proces budowy ŁKA nie powinien zostać zamknięty po uruchomieniu planowanych obecnie linii. Należy poszukiwać dalszych możliwości powiększenia obszaru obsługiwanego przez szynobusy, aby objać nim docelowo większość znaczących ośrodków województwa łódzkiego. To pozwoli na ich integrację z miastem Łódź, umożliwiając zarówno naukę na renomowanych uczelniach (Uniwersytet Łódzki, Politechnika Łódzka) studentom, jak i znalezienie pracy innym osobom.

Kolejnym sposobem minimalizowania zagrożeń jest odpowiednie sformułowanie przetargów, które ma na celu ograniczenie liczby odwołań. Większość postępowań przetargowych w Polsce zabiera bardzo dużo czasu, ponieważ każdy z przegranych wynajduje najmniejsze nawet błędy u innych podmiotów biorących udział w konkursie. Dlatego istotne jest takie sformułowanie wymagań, by maksymalnie obniżyć liczbę takich zachowań, co znajdzie swoje odzwierciedlenie w długości trwania postępowania przetargowego. Ważna kwestią są również kryteria, według których oceniane są oferty. Niestety, najczęściej głównym czynnikiem jest cena, która ma decydujące znaczenie, szacowane w okolicach $80 \%$. Pozostałe $20 \%$ to jakość, parametry techniczne, zastosowane technologie, serwis oraz termin wykonania zamówienia. Tak niezrozumiałe postępowanie znajduje później swój wyraz w informacjach o pękających odcinkach nowo wybudowanych autostrad czy też o nieprawidłowych surowcach zastosowanych przy budowie nasypów kolejowych. Często zdarzaja się niedotrzymane terminy czy brakuje środków na dokończenie budowy.

Jeśli chodzi o prawidłowe wykorzystanie funduszy europejskich, to proponowanym rozwiązaniem jest zatrudnienie podmiotu, którego zadaniem będzie nieustanna kontrola przepływów finansowych - przy czym, zdaniem autora, należy zwrócić się o pomoc do osób mających doświadczenie w tej materii. Jak pokazuja przypadki korzystania z funduszy UE w województwie łódzkim, na tym etapie bardzo często pojawiają się nieprawidłowości, co skutkuje żądaniami zwrotu części dotacji. Dotyczy to budowy Grupowej Oczyszczalni Ścieków, hali widowiskowej Atlas Arena czy też Tramwaju Regionalnego ${ }^{41}$.

W kwestii funduszy należy także przeprowadzić analizę finansową miast, które uczestnicza w projekcie oraz dokonać prognozy na przyszłe lata. Przypadek Zgierza i Pabianic podczas budowy ŁTR powinien być doświadczeniem, z którego należy wyciągnąć wnioski. Przy tej okazji warto również poszukać alternatywnych rozwiązań bądź zażądać zabezpieczeń.

${ }^{41}$ http://lodz.naszemiasto.pl/artykul/galeria/854314,lodz-odda-unii-100-mln-zl -za-gos-32-mln-zl-za-ltr,id,t.html [z dn. 23.03.2012]. 
Ważnych informacji dotyczących wyobrażeń co do funkcjonowania Łódzkiej Kolei Aglomeracyjnej dostarczyłyby też badania przeprowadzone wśród mieszkańców. Zdaniem autora, powinny być one przeprowadzone we wczesnej fazie, jeszcze przed uruchomieniem połączeń. Pozwoliłyby decydentom na uzyskanie odpowiedzi chociażby odnośnie do rozkładu jazdy na każdej z linii. Takie badania to ogromne źródło wiedzy, co pokazuja doświadczenia komunikacji miejskiej miasta Pabianic, gdzie ankieterzy przez jakiś czas zadawali pytania pasażerom. Po ich opracowaniu zupełnie zmieniono rozkłady jazdy, zlikwidowano część linii, powstały nowe połączenia. Działania te wprowadziły znaczne oszczędności, a pabianiczanie wydaja się zadowoleni z ich przeprowadzenia. Co prawda, ŁKA nie zmieni tras, natomiast odpowiednio przygotowane rozkłady jazdy będą wpływać na funkcjonowanie całego projektu.

Równie ważnym zadaniem jest zakup odpowiednich szynobusów. Wydaje się, iż najlepsze byłoby nabycie pojazdów, których modyfikacja (z dwuczłonowych w trójczłonowe i na odwrót) nie stanowiłoby dużego problemu. Ewentualnie aprobowanym rozwiązaniem mógłby być zakup pewnej liczby pojazdów składajacych się z dwóch wagonów, a pozostałe miałyby trzy wagony. Ma to związek z różnorodnością linii, na jakich szynobusy będą się poruszały. Linie w granicach administracyjnych Łodzi w ciągu całego dnia powinny mieć większe obłożenie pasażerami, niż linie kursujące np. do Zduńskiej Woli. Dokładne dane spłyna jednak dopiero po uruchomieniu całego sytemu, a to skutecznie uniemożliwia jednoznaczną ocenę problemu oraz znalezienie prawidłowego rozwiązania.

Istotnym czynnikiem powodzenia projektu jest wprowadzenie wspólnego biletu, który będzie obligował do korzystania z Łódzkiej Kolei Aglomeracyjnej oraz komunikacji miejskiej. Autor zdaje sobie sprawę, iż integracja wszystkich systemów miejskich z szynobusami jest zadaniem bardzo trudnym do zrealizowania, dlatego proponuje etapowe wprowadzanie tego udogodnienia. W pierwszej fazie należy zespolić miasto Łódź. Jeden bilet upoważniałby do korzystania z autobusów, tramwajów, a także ŁKA w granicach Łodzi. Następny etap to rozszerzenie oferty na miasta znajdujące się w bezpośrednim otoczeniu Łodzi, jak np. Pabianice. Dzięki temu można byłoby zbadać, czy istnieje zapotrzebowanie na dalsze poszerzanie terytorium obowiazywania takiego biletu. Doświadczenia wskazują na odpowiedź twierdząca, natomiast specyfika regionu łódzkiego przemawia za koniecznościa przeprowadzenia takiego doświadczenia.

Dużą rolę $w$ promowaniu korzystania $z$ ŁKA moga pełnić politycy zaangażowani w powstawanie projektu. Nadrzędnym zadaniem budowy tego systemu transportowego jest wzrost znaczenia transportu 
publicznego, który miałby przejawiać się w liczbie osób zamieniających podróżowanie samochodem na podróżowanie szynobusem. Dlatego też, zdaniem autora, odpowiednia zachęta ze strony osób, które najczęściej poruszają się autami, będzie bardziej skuteczna niż pozostałe formy reklamy. Jeżeli dołoży się do tego odpowiednią politykę cenową, to Łódzka Kolej Aglomeracyjna może stać się środkiem transportu tak istotnym dla województwa łódzkiego, jakim jest metro dla Warszawy.

\subsection{Oczekiwane efekty proponowanych zmian}

Zmiany sugerowane przez autora w poprzednim podrozdziale maja zoptymalizować działanie Łódzkiej Kolei Aglomeracyjnej. Sa to przede wszystkim działania, które należy wprowadzić we wczesnej fazie projektu, by jak najszybciej wyeliminować potencjalne zagrożenia. Autor bierze pod uwagę doświadczenia podobnych inwestycji i wskazuje błędy, odbijające się zarówno na funkcjonowaniu przedsięwzięć, jak i na ich postrzeganiu przez społeczeństwo. Ważna jest opinia mieszkańców, którzy patrząc na wcześniejsze niepowodzenia, moga stracić zainteresowanie realizowanym projektem. Dlatego też podjęte działania i odpowiednio przygotowana promocja maja za zadanie uzyskać poparcie dla inwestycji oraz chęć korzystania z usług ŁKA.

Przeprowadzane badania marketingowe pełnią dwojaką rolę. Pierwsza jest udoskonalenie rozkładu jazdy oraz optymalne dostosowanie ŁKA do potrzeb mieszkańców aglomeracji łódzkiej. Wydaje się, iż to właśnie osoby zamieszkujacce dane regiony będa $w$ stanie najlepiej dopasować plan kursowania szynobusów, tak aby spełniał on ich zapotrzebowanie na transport, a tym samym, by zapewnione było wymagane dla opłacalności obłożenie. Autor zdaje sobie sprawę, iż ustalenie rozkładu jazdy odpowiadającego wszystkim mieszkańcom byłoby trudne (biorąc pod uwagę rozległość ŁKA), jednak zebrane cenne wskazówki, jeżeli nie doprowadza do pełnej aprobaty, to pozwola choć w części udoskonalić inwestycję. W przypadku transportu, czy to miejskiego, czy aglomeracyjnego, często zdarza się, iż przesunięcie rozkładu o 3 do 5 min pozwoli zdecydowanie lepiej wykorzystać potencjał szynobusów.

Druga rolą badań jest satysfakcja mieszkańców z tego, iż biorą czynny udział w tworzeniu tak potężnego projektu, jakim jest Łódzka Kolej Aglomeracyjna. W opinii autora takie działanie wzbudzi sympatię, gdyż powszechnie wiadomo, że ludzie chętniej uczestnicza w czymś, czego są częścią i co w najmniejszym nawet stopniu jest ich zasługa. Warto 
przynajmniej spróbować wymazać ze świadomości łodzian i pozostałych mieszkańców obszarów objętych inwestycja chociażby niedogodności spowodowane przez budowę Łódzkiego Tramwaju Regionalnego oraz w efekcie końcowym jego klęskę jako elementu łączącego regiony. Poza tym nie należy zapominać, iż głównym celem jest namówienie społeczeństwa do częstszego korzystania z transportu zbiorowego kosztem środków własnych, a więc im większe zadowolenie mieszkańców i lepsze opinie, tym szansa na to się zwiększa.

Działania dotyczące prawidłowego wykorzystania funduszy unijnych maja zmierzać do uniknięcia zwrotów dopłat, które moga być zasądzone po kilku latach. Wymienione w poprzednim podrozdziale nieprawidłowości prowadziły do tego, iż podobne projekty przez długi czas będą generować koszty poprzez spłatę zobowiązań w ratach (o rozłożenie na raty miasto zaapelowało w przypadku Grupowej Oczyszczalni Ścieków, a w przypadku odszkodowania za ŁTR zapewne będzie podobnie, gdyż Łodzi nie stać na jednorazowa wpłatę w wysokości kilkunastu/kilkudziesięciu mln zł). Zatrudnienie zespołu osób wyłącznie do tej części przedsięwzięcia oraz nieustanna kontrola przepływów finansowych pozwoliłaby uniknać problemów z Unią Europejska, a tym samym doprowadziłaby do uzyskania rentowności przez opisywany projekt w krótszym terminie.

Jeśli chodzi o zagospodarowanie środków unijnych, istotne jest ich pełne wykorzystanie, tak by unikać sytuacji, w której okazuje się, iż np. na rozwój i modernizację transportu kolejowego przyznano Polsce ogromne kwoty, a następnie wychodzi na jaw, iż wykorzystano znikomy procent tej sumy. Łódź, będąc organizatorem projektu ŁKA, nie może sobie pozwolić na jakiekolwiek błędy w kwestii korzystania z funduszy i takie zadanie stałoby przed podmiotem, nad którego powołaniem zastanawia się autor.

Odpowiednie przygotowanie przetargów również odgrywa istotna rolę. W momencie, gdy wzrasta liczba samochodów poruszających się po drogach i rośnie liczba ofiar wypadków drogowych, ważnym celem staje się wcześniejszy termin zakończenia projektu Łódzkiej Kolei Aglomeracyjnej. Dokładne sprecyzowanie potrzeb i wymagań, określenie kryteriów, w których decydującym czynnikiem nie jest tylko niższa cena, pozwoli na szybsze zakończenie procedury, a tym samym wcześniejsze rozpoczęcie prac fizycznych przy ŁKA. Wskazanie na istotne znaczenie jakości ma na celu eliminację niedoróbek czy pomyłek w realizacji projektu, tak by nie generować dodatkowych kosztów oraz uniknąc opóźnień. Autor zdaje sobie sprawę, iż takie opracowanie przetargów jest trudnym zadaniem, wymagającym być może więcej nakładów (także finansowych), niemniej jednak uważa, iż pozwoli ono osiagnać większe korzyści przy realizacji całego projektu. 
Przy powstawaniu Łódzkiej Kolei Aglomeracyjnej włączenie osób posiadających doświadczenie zdecydowanie zwiększy szansę powodzenia przedsięwzięcia. Autorzy np. rozwiązań berlińskich będa potrafili wskazać zadania wymagające szczególnej uwagi, zarówno jeśli chodzi o tabor, infrastrukturę czy samo funkcjonowanie całego systemu. Zapewne widoczne będą efekty dotyczące terminu realizacji, gdyż wiedza osób biorących udział w podobnych inwestycjach powinna pozwolić na ukończenie ŁKA w krótszym niż zakładano terminie. Równie istotnym czynnikiem są rozwiązania w aspekcie bezpieczeństwa, które Niemcy maja już opracowane na podstawie wieloletniej działalności S-Bahn. W obecnej sytuacji nie ma miejsca na błędy, próby czy doświadczenia. Zdaniem autora, wiedza doświadczonych osób będzie miała znaczenie na każdym etapie planowanych prac i gdy uda się ją wykorzystać, mieszkańcy aglomeracji łódzkiej nie będą musieli słuchać o kilkumiesięcznych opóźnieniach, nieprzewidzianych wydatkach, poprawkach w pracach czy też niepowodzeniu całego projektu. I takie efekty tego rozwiązania zakłada autor pracy, sugerujac, iż jest to jeden z kluczowych czynników sukcesu ŁKA.

Poszerzanie terenów objętych funkcjonowaniem Łódzkiej Kolei Aglomeracyjnej będzie skutkować integracją województwa, co ma znaczenie zarówno jeśli chodzi o naukę i pracę, jak też o kulturę i turystykę. Będzie to sprzyjać wyrównaniu szans dla osób mających utrudniony dostęp do wysokiej rangi uczelni, czy też zakładów pracy o wyższym potencjale. Istniejące plany obejmuja wiele miast odległych o kilkadziesiąt kilometrów od stolicy aglomeracji, dlatego też dodatkowe kilkanaście kilometrów nie powinno stanowić znaczącej różnicy, tym bardziej, że koszty pokrywane są w części przez samorządy terytorialne uczestników projektu. Ponadto w obliczu opóźnień w powstawaniu dróg i autostrad warto zapewnić alternatywę w postaci jak najszerszej oferty połączeń minimalizującej znaczenie transportu drogowego.

Istotnym aspektem, którego skutki będą długo odczuwalne, jest trafny wybór pojazdów. Zakup szynobusów w najbliższej przyszłości jest zdarzeniem jednorazowym, dlatego nie można pozwolić sobie na zaniedbanie w tej kwestii. Dalekosiężnym efektem będzie większa liczba osób, która może korzystać z usług ŁKA. Jest to bardzo ważny czynnik, mający wpływ na opłacalność całego projektu. Zdaniem autora, liczba osób przemieszczających się szynobusami powinna się zwiększać na przestrzeni lat, dlatego należy zadbać o komfort podróżowania, by mieszkańcy aglomeracji nie musieli poruszać się zatłoczonymi pojazdami. Idealnym rozwiązaniem wydaja się szynobusy, które można będzie łatwo modernizować, tak by za kilka lat nie trzeba było ogłaszać kolejnego przetargu dotyczącego dostawy pojazdów. Miałoby 
to sens w przypadku zwiększenia częstotliwości połączeń, co niestety na niektórych liniach wiązać się będzie z koniecznością budowy dodatkowej infrastruktury. Jeżeli szynobusy "zdadzą egzamin", łatwiej będzie osiagnać zamierzone cele i zmienić strukturę środków transportu najczęściej używanych w czasie dojazdów do pracy lub na uczelnię.

Kolejnym czynnikiem, na który zwrócono uwagę, jest wprowadzenie wspólnego biletu. Jest to, zdaniem autora, rozwiązanie niezbędne dla pełnej funkcjonalności Łódzkiej Kolei Aglomeracyjnej. Dodatkowa synchronizacja ze spółkami miejskich przedsiębiorstw komunikacyjnych byłaby czynnikiem pozytywnie wpływającym na rozwój transportu zbiorowego w obrębie aglomeracji. Należy podkreślić możliwe korzyści w postaci oszczędności czasu i pieniędzy dla podróżujących oraz korzyści związane z emisja mniejszej liczby biletów na rynku (niższe nakłady finansowe na produkcję biletów jednorazowych czy też biletów okresowych upoważniających do korzystania z usług jednej firmy). Wiadome jest jednak, iż wspólny bilet wymaga negocjacji wielu stron, co nie ułatwia jego wprowadzenia. Autor zdaje sobie sprawę z tych trudności, jednakże uważa, iż zadaniem spółek oferujących usługi transportu zbiorowego jest przede wszystkim służba pasażerowi i zaspokojenie jego potrzeb związanych z przemieszczaniem się.

Promocja ŁKA w sposób proponowany przez autora ma przekonać społeczeństwo do korzystania z szynobusów. Rozwiązaniem docelowym jest zmniejszenie udziału indywidualnego transportu drogowego na rzecz aglomeracyjnego transportu zbiorowego. Wiazża się z tym przede wszystkim korzyści na rzecz ochrony środowiska naturalnego. Autor ma nadzieję, iż długofalowe wsparcie lokalnych polityków, którzy byli zaangażowani w powstawanie Łódzkiej Kolei Aglomeracyjnej, znajdzie swoje odbicie w liczbie chętnych do skorzystania z dobrodziejstw tego projektu.

\section{Podsumowanie}

W wyniku analiz przeprowadzonych w niniejszym rozdziale sformułowano następujące wnioski:

- Pomysł budowy Łódzkiej Kolei Aglomeracyjnej powstał w marcu 2008 r., a wstępne założenia wskazuja na rozpoczęcie jej funkcjonowania w roku 2013.

- Do obsługi połączeń zostanie zakupionych 20 szynobusów, których właścicielem będzie specjalnie powstała Łódzka Kolej Aglomeracyjna Sp. z o.o. 
- Plany obejmuja kursowanie pojazdów na trasach z Łodzi do Kutna, Łowicza, Koluszek i Zduńskiej Woli, a ponadto linię wewnętrzną Łódź Widzew-Łódź Kaliska.

- W ramach projektu zostana zmodernizowane i odnowione dworce, powstana nowe przystanki, a także zostanie wybudowane zaplecze techniczne.

- Główne korzyści z powstania ŁKA maja charakter społeczno-gospodarczy, pozostałe dotyczą aspektów środowiskowych oraz płynących ze zrównoważonego rozwoju.

- Równolegle z projektem kolei aglomeracyjnej w Łodzi realizowane sa inwestycje, takie jak: budowa ringu autostradowego wokół miasta, przebudowa Dworca Fabrycznego, powstanie Nowego Centrum Łodzi, a także powiązana $z$ ŁKA budowa tunelu średnicowego pod Łodzią.

- Budowa systemu Łódzkiej Kolei Aglomeracyjnej została podzielona na 3 etapy, z których pierwszy ma być zakończony w roku 2015, drugi w 2020, a trzeci w 2026.

- Problemy z powstaniem ŁKA dotycza wielu płaszczyzn, a najważniejsze z nich to organizacja przetargów, wykorzystanie przyznanych funduszy, zakup odpowiednich szynobusów, modernizacja infrastruktury oraz brak synchronizacji z komunikacja miejską.

- Niwelowanie zagrożeń należy rozpoczać już w fazie planowania.

- Nie można pozwolić sobie na opóźnienia oraz znaczący wzrost kosztów.

- Badania wśród społeczeństwa oraz doświadczenia zagraniczne sa recepta na rozwiązanie wielu problemów.

- Wspólny bilet to konieczność.

- Proponowane zmiany maja na celu optymalizację działania Łódzkiej Kolei Aglomeracyjnej, eliminację błędów oraz zachęcenie społeczeństwa do korzystania z tej formy transportu. 



\section{Bibliografia}

Analiza warunków budowy kolejowego tunelu średnicowego pod centrum Łodzi - podsumowanie i wnioski, Stowarzyszenie Inżynierów i Techników Komunikacji RP, Łódź 2008.

Biello D. i in., Bullet trains: inside and out, PowerPlus Books, New York 2002.

Biuletyn Informacyjny Biura Rozwoju Przedsiębiorczości i Miejsc Pracy Urzędu Miasta Łodzi, 2012.

Bruinsma F., Pels E. i in., Railway developement: impacts on urban dynamics, Wyd. Physica-Verlag, Heidelberg 2008.

Brzeziński C., Łódź jako centrum logistyczne transportu - uwarunkowania, materiały z konferencji organizowanej przez Prezydenta Miasta Łodzi "Multimodalne węzły transportu czynnikiem rozwoju regionów", Urząd Miasta Łodzi, marzec 2004.

Chmielak A. (red.), Wybrane problemy kształtowania infrastruktury rozwoju zrównoważonego, Wyd. Politechniki Białostockiej, Białystok 2001.

Chrzanowski J., Siedemdziesiąt lat magistrali węglowej, "Nasz Tygodnik", 21.05.2010, dodatek do "Dziennika Łódzkiego".

Dyrekcja Generalna ds. Energii i Transportu Komisji Europejskiej, EU energy and transport in figures. Statistical Pocketbook 2009, Brussel 2009.

Dyrektywa nr 96/48/WE z dn. 23 lipca 1996 r. w sprawie interoperacyjności transeuropejskiego systemu kolei dużych prędkości, Dz.U. L 235 z 17.09.1996.

ECMT, Transport infrastructure in ECMT countries: profiles and prospects (monographs), Paris 1998.

Encyklopedia Popularna PWN, Wyd. Naukowe PWN, Warszawa 1995.

Ficoń K., Zarys mikrologistyki, Bel Studio Sp. z o.o., Warszawa-Gdynia 2004.

Furtak K., Kędracki M., Podstawy budowy tuneli, Wyd. Politechniki Krakowskiej, Kraków 2005.

Gałuszka J. (red.), Wokół Nowego Centrum Łodzi, EC1 - Miasto Kultury, Łódź 2010.

Dyrekcja Generalna ds. Prasy i Komunikacji Komisji Europejskiej, Europe at a crossroads. The need for sustainable transport, Brussel 2003.

Główny Urząd Statystyczny, Mały Rocznik Statystyczny Polski 2009, Zakład Wydawnictw Statystycznych, Warszawa 2009.

Gołembska E. (red.), Współczesne kierunki rozwoju logistyki, Polskie Wyd. Ekonomiczne, Warszawa 2006.

Grzywacz W., Infrastruktura transportu, Wyd. Komunikacji i Łączności, Warszawa 1982.

Jerczyński M., Roszek T., Szlakiem łódzkiej kolei, Piątek Trzynastego, Łódź 2003.

Jewtuchowicz A. (red.), Strategiczne problemy rozwoju regionów $w$ procesie integracji europejskiej, Wyd. Uniwersytetu Łódzkiego, Łódź 2001.

Jewtuchowicz A., Suliborski A. (red.), Struktury i procesy kształtujące łódzki region społeczno-gospodarczy, Wyd. Biblioteka, Łódź 2002.

Jewtuchowicz A., Wójcik M. (red.), Łódzka metropolia. Problemy integracji gospodarczej, Wyd. Biblioteka, Łódź 2010.

Jones R. A., The politics and economics of the European Union: an introductory text, Wyd. Elgar, Cheltenham 2001.

Koleje DB wchodzą do klubu prędkości 300 km/h, Aktualności, "Technika Transportu Szynowego" 2002, nr 1-2. 
Kowalczyk K., Kłopoty ze skansenem, "Siedem Dni - Zduńska Wola” 2010, nr 16 (611), kwiecień.

Koziarski S. M., Sieć kolejowa Polski w latach 1918-1992, Instytut Śląski, Opole 1993.

Kozłowski R., Tomczyk I., Problematyka budowy dróg w Polsce na przykładzie drogi ekspresowej S-8 w województwie łódzkim, 2K s.c., Łódź-Sieradz 2009.

Lachiewicz S., Staniec I. (red.), Sytuacja ekonomiczna, organizacyjna i kadrowa dużych organizacji gospodarczych w aglomeracji łódzkiej, Wyd. Media Press, Łódź 2007.

Leśniewicz W. L., Na S8 trzeba poczekać, "Dziennik Łódzki”, 18.01.2010, nr 14 (22.410). Lowe D., Intermodal freight transport, Elsevier Butterworth-Heinemann, Amsterdam 2005. Massel A., Linia dużych prędkości Wrocław/Poznań-Łódź-Warszawa, „Technika Transportu Szynowego" 2005, nr 12 (grudzień).

Maynard Ch., High-speed trains, Wyd. LernerSports, Minneapolis 2002.

Miecznikowski S. (red.), Gospodarowanie w transporcie kolejowym Unii Europejskiej, Wyd. Uniwersytetu Gdańskiego, Gdańsk 2007.

Ministerstwo Rozwoju Regionalnego, Strategia rozwoju kraju 2007-2015, Warszawa 2006 (listopad).

Mirski J. Z., Budownictwo z technologia, Wyd. Szkolne i Pedagogiczne, Warszawa 1995.

Neider J., Transport międzynarodowy, Polskie Wyd. Ekonomiczne, Warszawa 2008.

Nietz F., W 35 minut do Łodzi, "Gazeta Transportowa" 2009, nr 49 (863), grudzień.

North B. H. (red.), Modern railway transportation: proceedings of the International Conference "Railways", organized by the Institution of Civil Engineers and held in London on 25-27 May 1993, Redwood Books, London 1993.

OECD, Przeglądy gospodarcze OECD - Polska, t. 2008/10, Instytut Technologii Eksploatacji, Radom 2008.

Poradowski R., Zduńska Wola i okolice, Tow. Przyjaciół Zduńskiej Woli, Zduńska Wola 1984.

Porozumienie w sprawie realizacji studium wykonalności dla tunelu średnicowego, Miasto Łódź, PKP Polskie Linie Kolejowe S.A., EC-1 Łódź - Miasto Kultury, Łódź, 26.09.2009.

Projektowane linie średnicowe $w$ Łodzi jako element systemu KDP oraz kolei konwencjonalnych -prezentacja ustaleń studium wykonalności, Warszawa-Łódź, grudzień 2011.

Raczyński J., Massel A., Uwarunkowania społeczne i gospodarcze rozwoju kolei dużych prędkości w Polsce, "Technika Transportu Szynowego" 2005, nr 5-6 (maj-czerwiec).

Raczyński J., Rządowy program budowy linii dużych prędkości w Polsce, "Technika Transportu Szynowego" 2008, nr 9 (wrzesień).

Raczyński J., TGV Mediterranee - piąta linia dużej prędkości we Francji, „Technika Transportu Szynowego" 2001, nr 6.

Raczyński J., Żurkowski A., Koleje dużych prędkości w Europie i projekty budowy nowych linii w Polsce, "Technika Transportu Szynowego" 2006, nr 4 (kwiecień).

Ross J. F. L., Linking Europe: transport policies and politics in the European Union, Wyd. Praeger, Westport 1998.

Roza G., The incredible story of trains, Powerkids Press, New York 2004.

Rydzkowski W., Wojewódzka-Król K., Transport. Problemy transportu w rozszerzonej UE, PWN, Warszawa 2009.

Sievert T., The world's fastest trains, Capstone Press, Mankato 2002.

Sitarek M., Duży krok naprzód, "Siedem dni - Sieradz" 2010, nr 3 (598), styczeń.

Słownik wyrazów obcych, PWN, Warszawa 1993.

Studium przebiegu przez Łódź Kolei Dużych Prędkości V-300, TEREN Sp. z 0.0., Łódź 2006. Suchański T., S8 - jest decyzja, "Siedem Dni - Zduńska Wola” 2010, nr 3 (598), styczeń. Śmiałowski J., Zakład Taboru Polskich Kolei Państwowych w Zduńskiej Woli-Karsznicach (rok zał. 1933), Wyd. Biblioteka, Zgierz 1996. 
Taylor Z., Regres i rozwój sieci kolei w Polsce, PAN Instytut Geografii i Przestrzennego zagospodarowania, Warszawa 2007.

Tomanka R. (red.), Ceny transportu miejskiego w Europie, Wyd. Akademii Ekonomicznej w Katowicach, Katowice 2007.

Towpik K., Linie kolejowe dużych prędkości. Stan obecny i kierunki rozwoju wybranych zagadnień z zakresu dróg kolejowych, „Problemy Kolejnictwa” 2002, nr 136.

UIC, High speed rail. Fast track to sustainable mobility, November 2010.

Wesołowski J., Ukształtowanie kolejowego węzła łódzkiego i możliwości jego włączenia w system kolei dużych prędkości, „Technika Transportu Szynowego" 2005, nr 12 (grudzień).

Woźniak K., Francuską koleją przez Karsznice, "Ziemia Łódzka” 2009, nr 10 (99), październik.

Żurkowski A., Duże prędkości - UIC, Polska, „Technika Transportu Szynowego" 2005, nr 5-6 (maj-czerwiec).

\section{Strony internetowe}

http://bppwl.lodzkie.pl

http://ec.europa.eu

http://edgp.gazetaprawna.pl

http://epp.eurostat.ec.europa.eu

http://forsal.pl

http://forum.gazeta.pl

http://gospodarka.gazeta.pl

http://historia.arch.p.lodz.pl

http://inforail.pl

http://kolej.krb.com.pl

http://lka.lodz.pl

http://lodz.gazeta.pl

http://lodz.naszemiasto.pl

http://logistyka.wnp.pl

http://miasta.gazeta.pl

http://miasteria.pl

http://mpu.lodz.pl

http://natura2000.gdos.gov.pl

http://serwisy.gazeta.pl

http://szybkiekoleje.org.pl

http://um.kutno.pl

http://uml.lodz.pl

http://zdunska wola.naszemiasto.pl

http://zsk.dbv.pl

www.abc.com.pl

www.alwaystouchout.com

www.bahn.de

www.belrail.be

www.bombardier.com

www.bpk.lodz.pl

www.cie.gov.pl www.citytunnelleipzig.de

www.croydon-tramlink.co.uk

www.dft.gov.uk

www.dhl.com.pl

www.dzienniklodzki.pl

www.ec1kolejowy.pl

www.ec1lodz.pl

www.eos.ubc.ca

www.gddkia.gov.pl

www.inforail.p

www.infrastruktura.elamed.pl

www.klimatdlaziemi.pl

www.konwent.lodzkie.pl

www.laser-sinex.pl

www.lddc-history.org.uk

www.leipzig.de

www.lekkerland.pl

www.lka.lodzkie.pl

www.lodzkie.eu

www.lodz-sitk.org.pl

www.Itmcollection.org

www.microsofttranslator.com

www.mpips.gov.pl

www.nbi.com.pl

www.obywatel.org.pl

www.pkp.pl

www.plk-inwestycje.pl

www.plk-sa.pl

www.poznan.gddkia.gov.pl

www.railway-technology.com

www.rynek-kolejowy.pl 
www.rzecznik.dlalodzi.info www.segro.pl www.stat.gov.pl www.szybkiekoleje.org.pl www.technologyreview.com www.tfl.gov.uk www.timeout.com www.toya.net.pl www.trainweb.org www.transport-szynowy.pl www.uic.org www.ukie.gov.pl www.uml.lodz.pl www.uni-logistics.eu www.ventra.com.pl www.zdit.uml.lodz.pl 


\section{Spis tabel, rysunków, wykresów}

\section{Tabele}

Tabela 1. Struktura zatrudnienia, ilość przedsiębiorstw oraz ich obrót w poszczególnych gałęziach i sektorach transportu dla całej UE w 2006 r. ..............................20

Tabela 2. Najważniejsze cechy wariantu 1 i 3 przebiegu KDP w Polsce ....................44

Tabela 3. Stan połączeń Łodzi z sąsiednimi regionami w 2007 r. ..........................55

Tabela 4. Stan kolejowych połączeń pasażerskich w regionie łódzkim w 2007 r. ........56

Tabela 5. Partycypacja w kosztach budowy tunelu średnicowego w Lipsku ...............79

Tabela 6 . Koszty wykonania inwestycji w odniesieniu do poszczególnych wariantów

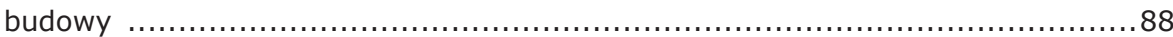

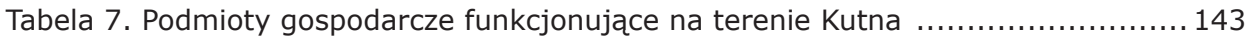

Tabela 8. Długość linii metra, liczba obsługiwanych stacji i zajezdnie ..................... 154

\section{Rysunki}

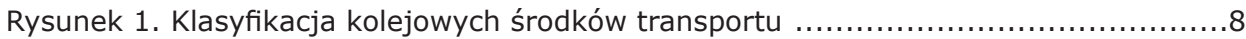

Rysunek 2. Transeuropejska Sieć Kolejowa .............................................. 17

Rysunek 3. Udział linii kolejowych zelektryfikowanych w ogólnej długości linii normalnotorowych eksploatowanych według województw w 2008 r. .................21

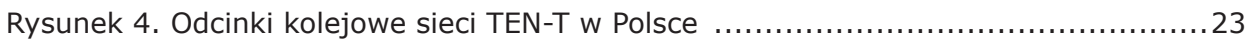

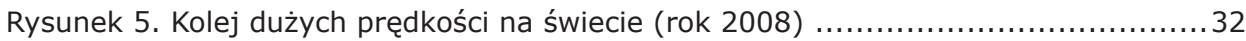

Rysunek 6. Czas podróży koleją konwencjonalną i szybką koleją ........................38

Rysunek 7. Transeuropejska sieć szybkiej kolei - prognoza na 2025 rok ................40

Rysunek 8. Optymalny układ połączeń między głównymi miastami Polski i krajami

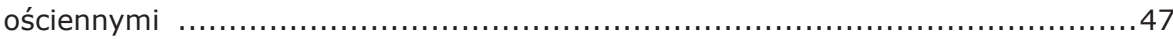

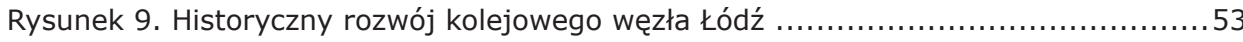

Rysunek 10. Przebieg linii kolei dużych prędkości przez województwo łódzkie ...........60

Rysunek 11. Planowany przebieg trasy S8 w rejonie Zduńskiej Woli ......................97

Rysunek 12. Wschodnia głowica stacji Olechów .......................................... 108

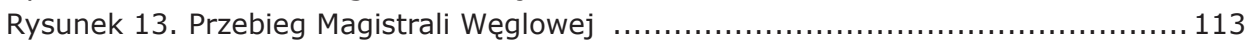

Rysunek 14. Pociagg z węglem na stacji Zduńska Wola ................................ 114

Rysunek 15. Hale naprawcze lokomotyw .......................................... 116

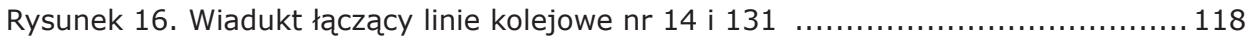

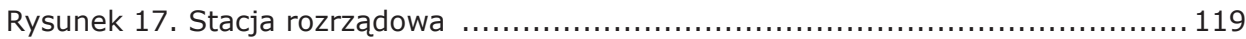

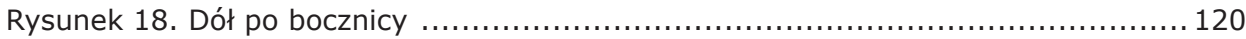

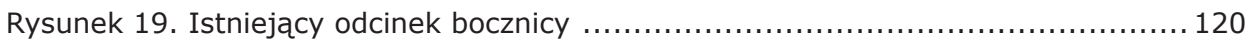

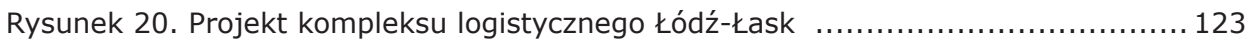

Rysunek 21. Lokalizacja węzła Zduńska Wola Karsznice przy S8 ....................... 124

Rysunek 22. Plan kolejowy pokazujący integrację systemów według Biura

Planowania Przestrzennego Województwa Łódzkiego 
Rysunek 23. Plan zagospodarowania przestrzennego infrastruktury według Biura

Planowania Przestrzennego Województwa Łódzkiego ............................. 130

Rysunek 24. Projekt przedłużenia linii Metropolitan do Watford Junction ................ 162

Rysunek 25. Mapa Łódzkiej Kolei Aglomeracyjnej ..................................... 178

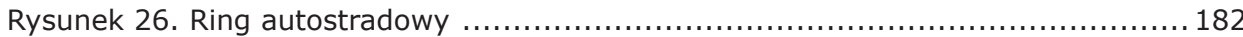

Rysunek 27. Mapa przedstawiająca przebieg tuneli średnicowych pod Łodzią .......... 184

\section{Wykresy}

Wykres 1. Emisja dwutlenku węgla związana z przewozem 100-tonowego ładunku na trasie Basel-Rotterdam (700 km)

Wykres 2. Emisja dwutlenku węgla związana z przewozem 1 osoby na trasie BerlinFrankfurt $(545 \mathrm{~km})$

Wykres 3. Udział poszczególnych gałęzi transportu w przewozach towarów wewnątrz Unii Europejskiej

Wykres 4. Udział poszczególnych gałęzi transportu w przewozach pasażerów

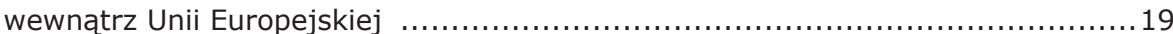

Wykres 5. Rozwój sieci szybkiej kolei na świecie w latach 1964-2024 .................... 30

Wykres 6. Liczba obsłużonych pasażerów (w mln) London Tramlink w poszczególnych

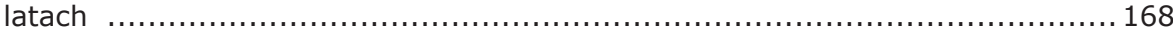

